\title{
EDUCAÇÃO NO SÉCULO XXI
}

ENSINO DE CIÊNCIAS

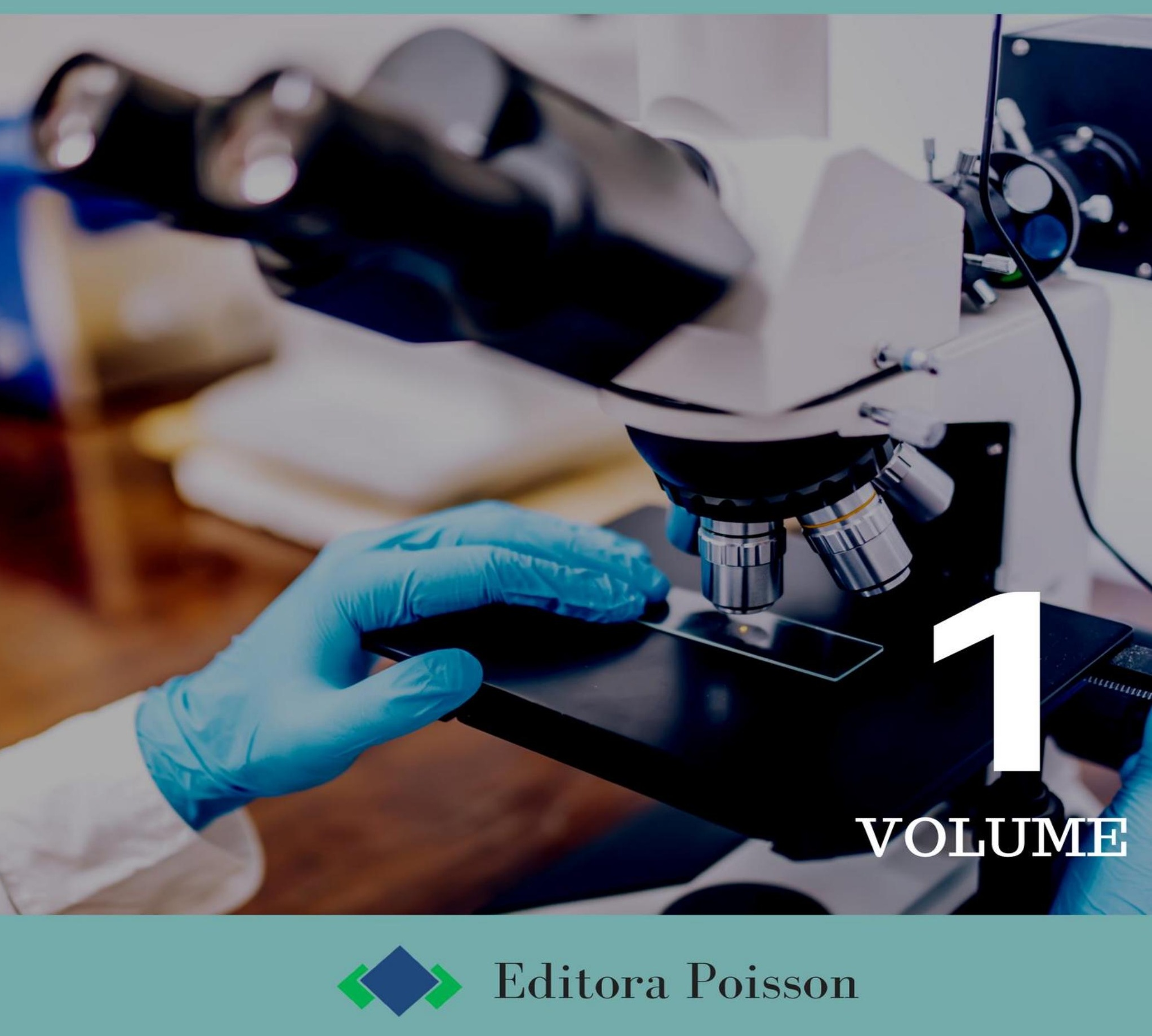


Editora Poisson

\section{Educação no Século XXI Volume 1}

1a Edição

Belo Horizonte

Poisson

2018 
Editor Chefe: Dr. Darly Fernando Andrade

\section{Conselho Editorial}

Dr. Antônio Artur de Souza - Universidade Federal de Minas Gerais

Dra. Cacilda Nacur Lorentz - Universidade do Estado de Minas Gerais

Dr. José Eduardo Ferreira Lopes - Universidade Federal de Uberlândia

Dr. Otaviano Francisco Neves - Pontifícia Universidade Católica de Minas Gerais

Dr. Luiz Cláudio de Lima - Universidade FUMEC

Dr. Nelson Ferreira Filho - Faculdades Kennedy

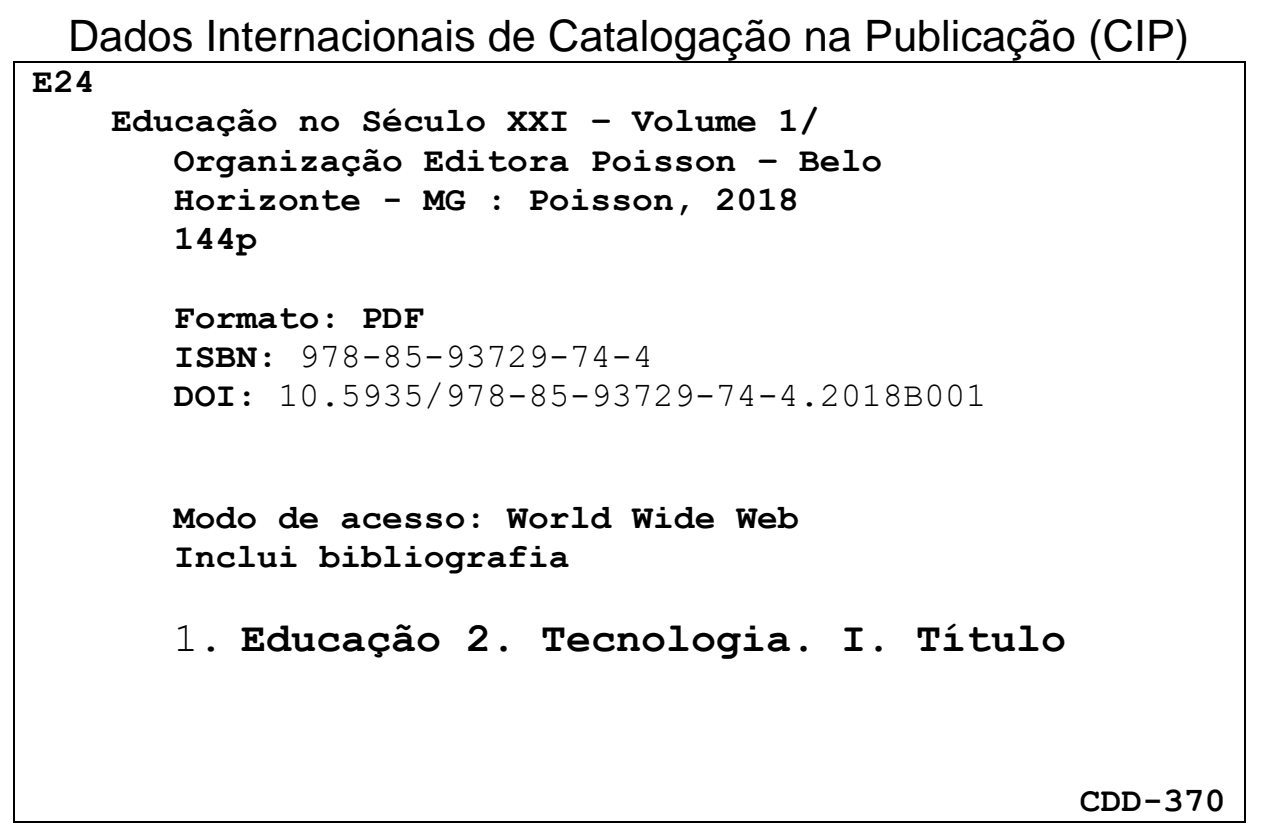

O conteúdo dos artigos e seus dados em sua forma, correção e confiabilidade são de responsabilidade exclusiva dos seus respectivos autores. Os artigos contidos nessa obra foram originalmente apresentados no XI Encontro Nacional de Pesquisa em Educação em Ciências - XI ENPEC Universidade Federal de Santa Catarina, Florianópolis, SC-3 a 6 de julho de 2017 


\section{SUMÁRIO}

Capítulo 1: O cuidar e o educar como premissa para o ensino de ciências dos anos iniciais do ensino fundamental....

Rosana Chermont Mesquita, Daniele Dorotéia Rocha da Silva de Lima, Aldinéia do Socorro Oliveira Maia Pereira

Capítulo 2: Aprendizagem baseada na resolução de problemas e a elaboração de questões no ensino fundamental

Patrícia Regina Carvalho Ottz, Antonio Henrique Pinto, Manuella Villar Amado

Capítulo 3: Indicadores de interdisciplinaridade em um grupo de estudos: uma reflexão ao ensino de temas ambientais na formação inicial de professores

Giselle Alves Martins, Paula de Oliveira Souza, Gabriel dos Santos Paulon, Fernanda da Rocha Brando, Taitiâny Kárita Bonzanini

Capítulo 4: Percepção de estudantes sobre o Ambiente Urbano José Daniel Soler Garves, Ângela Coletto Morales Escolano

Capítulo 5: Aprendendo ciências e desenvolvendo criticidade nos ambientes costeiros sul capixabas

Guilherme Augusto Maciel Ribeiro, Brenda Odete Pfeiffer de Araújo, Luciane da Silva Lima Vieira, Maria Margareth Cancian Roldi, Carlos Roberto Pires Campos

Capítulo 6: A aprendizagem conceitual acerca da condutividade elétrica das substâncias através de habilidades desenvolvidas pela experimentação.

Carlos Eduardo Pereira Aguiar, Roberto Barbosa de Castilho

Capítulo 7: Momento Químico: reflexões sobre um jornal de divulgação científica no âmbito de um curso de licenciatura em química.

Brenno Ralf Maciel Oliveira, Tatiana Comiotto, Fabíola Sucupira Ferreira Sell, Carlos Eduardo Rocha, Duan Ceola, Maria Elise Sonnenhohl, Isadora Jorge Velloso

Capítulo 8: O experimento de Rutherford em livros didáticos brasileiros: reprodução de estilos de pensamento e transposição didática. 


\section{SUMÁRIO}

Capítulo 9: História da Ciência e aplicações no ensino básico de Biologia: uma investigação dos anais dos ENPECs de 2007 a 2015......

Luana Beatriz Xavier Nunes, Magda Medhat Pechliye

Capítulo 10: Proposições de professores acerca da problematização de temas científicos por meio de livros paradidáticos e/ou de divulgação científica.

Anelise Grünfeld de Luca, Sandra Aparecida dos Santos, José Claudio Del Pino, Michelle Câmara Pizzato

Capítulo 11: Lei no 13.146, de 6 de julho de 2015: uma leitura

Veronica Ribeiro da Silva Cordovil, Marcela Arantes Ribeiro

Capítulo 12: Motivação dos alunos em sala de aula: comparação entre uma aula ativa de um curso semipresencial e uma aula expositiva de um curso presencial da área de saúde.

Paula Moiana da Costa, Fernando Hitomi Matsubara, Samia Moreira Akel

Capítulo 13: Ilha interdisciplinar de racionalidade: o potencial do complexo do Ver-o-Peso como contexto para aprendizagem de Ciências Naturais

Jorge Raimundo da Trindade Souza, José Alexandre da Silva Valente, Ana Cristina Pimentel Carneiro de Almeida, Licurgo Peixoto de Brito

Capítulo 14: Estratégias de ensino para a construção de produtos tecnológicos mediante a implementação de resíduos sólidos.

Jakeline Amparo Villota Enríquez, Maribel Deicy Villota Enríque

Capítulo 15: Metodologias ativas: tecnologias assistivas com um novo olhar para a inclusão

Rita de Cássia Borges de Magalhães Amaral, Nacyra Yiburi Fernandes de Lucena, Fernanda Beatriz Pereira de Abreu, Juçara Pereira Barbosa, Rejane Araújo da Silva

Autores: 


\section{Capítulo 1}

\section{O CUIDAR E O EDUCAR COMO PREMISSA PARA O ENSINO DE CIENCIAS DOS ANOS INICIAIS DO ENSINO FUNDAMENTAL}

\section{Rosana Chermont Mesquita}

Daniele Dorotéia Rocha da Silva de Lima

\section{Aldinéia do Socorro Oliveira Maia Pereira}

Resumo: Analisamos a relação do Binômio Cuidar-Educar com o Ensino de Ciências nos Anos Iniciais do Ensino Fundamental, visando refletir acerca do respeito às necessidades das crianças sobre acesso ao conhecimento científico, considerando o cuidar e o educar como premissas do ato de ensinar e de aprender. Espera-se com isso apontar a relevância de um trabalho pedagógico transdisciplinar nos Anos Iniciais, onde o Ensino de Ciências seja parte integrante da apropriação da Língua Materna pela criança, evidenciando que o cuidar e educar tão peculiar ao campo pedagógico, é também promotor de significativas aprendizagens no campo da Ciência. Neste sentido, consideramos relevante tal estudo na perspectiva de dialogar e fundamentar a relação intrínseca entre o cuidar e educar e o ensino de ciências nos anos iniciais, na perspectiva de fortalecermos o diálogo acerca da capacidade de crianças pequenas (6 a 10 anos) de aprenderem, analisarem e reconstruírem conhecimento nesta área.

Palavras chave: Ensino de Ciência - Cuidar e Educar - Conhecimento Científico 


\section{INTRODUÇÃO}

As grandes dificuldades que encontramos em efetivar uma política pública de qualidade social para o Ensino Fundamental revelam o quanto precisamos desenvolver um olhar atento à relação entre o cuidar e o educar que extrapole os espaços de Educação Infantil e seja incorporado a práxis educativa da Educação Básica em sua totalidade, considerando que se faz necessário atentarmos para os fenômenos sociais que interferem diretamente no processo ensinoaprendizagem, que muitas vezes criam uma estrutura maléfica de retenção e não aprendizagem, agravada com realidades de pobreza e desigualdades sociais.

Por outro lado as pesquisas sobre o ensino de ciências para os anos iniciais do ensino fundamental sinalizam a importância de proporcionar aos alunos situações problemáticas, a fim de que se aproximem de conceitos científicos e reconstruam os conhecimentos socialmente adquiridos (GONÇALVES \& CARVALHO, 1996). É importante que os conhecimentos na área de Ciências abordados nos anos iniciais de escolarização, estejam relacionados a outras áreas curriculares a partir de atividades que focalizem a apropriação da escrita da língua materna, mas que respeite a linguagem científica, levando em consideração o desenvolvimento cognitivo dos alunos (SOUZA; SANTOS; SOUZA JÚNIOR, 2011), contribuindo para que possam explorar seus contextos de vivências.

Promover um ensino interdisciplinar e contextualizado nos anos iniciais é um desafio permanente, pois requer a criação de espaços desafiadores e propícios à investigação e à construção de conhecimentos científicos, requer professores que acreditem na promoção de desenvolvimento da maturidade das crianças para aprender conhecimentos científicos e busquem o desenvolvimento de um trabalho sistemático.

É pertinente compreender que o binômio cuidar e educar, historicamente, tem maior repercussão no âmbito da Educação Infantil, posto ser o trabalho educacional desenvolvido com esta faixa etária (zero a cinco anos) apontado como um processo educativo que precisa de uma atenção especial que articule as necessidades básicas como a alimentação, higiene e saúde de crianças. Entretanto, é importante refletirmos também acerca dessas necessidades básicas (alimentação, higiene e saúde) ao lidarmos com as crianças de seis a doze anos, dos adolescentes, jovens e adultos no ambiento do processo educativo.

O cuidar e educar são duas dimensões indissociáveis no processo de construção do conhecimento, independente da faixa etária trabalhada, pois envolve a preocupação com os tempos e espaços que assegure ao educando o respeito ao direito de brincar, a curiosidade, ao acolhimento, ao lúdico, a interação, e particularmente, a construção e respeito às diferentes identidades e conhecimentos. Nesta perspectiva:

\section{A base do cuidado humano é compreender como ajudar o outro a se desenvolver como ser humano. Cuidar significa valorizar e ajudar a desenvolver capacidades. O cuidado é um ato em relação ao outro e a si próprio que possui uma dimensão expressiva e implica em procedimentos específicos (BRASIL, 2001, p.24).}

Deste modo, o binômio cuidar-educar é premissa indispensável para o Ensino de Ciências nos Anos Iniciais, fundamenta o Homem como ser capaz de desenvolver capacidades e habilidades que venham a contribuir para uma sociedade mais fecunda no que tange ao respeito as diferenças e ao cuidado com o meio ambiente, bem como com aos outros, comprometendo-nos com o bem estar social.

Neste sentido, a partir da pesquisa bibliográfica, busca-se construir significados reflexivos sobre: 0 cuidar e o educar como premissa para o Ensino de Ciências dos Anos Iniciais do Ensino Fundamental, que nos ajude a pensar questões expressas no cotidiano de escolas e professores, ampliando posicionamentos, valores, medo, como possibilidades de melhor qualificarmos o ensino de ciências nos anos iniciais. 


\section{O CUIDAR E EDUCAR COMO PRINCÍPIOS PARA UMA EDUCAÇÃO DE QUALIDADE}

Partimos do pressuposto que a educação tem por finalidade maior a promoção da formação e o desenvolvimento humano em todas as suas dimensões. Tornando-se um dos instrumentos que impulsionam o progresso social, e que é essencial para a constituição da cidadania, para a inclusão social e para a consciência planetária; o que por sua vez gera um certo impacto positivo na qualidade de vida, na produtividade e nos avanços tecnológicos e econômicos de um país. Assim, compreende-se que a educação constitui-se em um dos pilares fundamentais de um projeto de nação comprometido com a democracia e com os princípios de justiça e igualdade social, bem como a sobrevivência do planeta.

É fato que a Educação brasileira está se qualificando, porém ainda precisamos avançar no que se refere a aprendizagem, pois mesmo com a diminuição do número de analfabetos, uma parcela considerável da população ainda não se apropriou, no sentido pleno desta palavra, da leitura e da escrita, muitos jovens ainda saem do Ensino Médio, última etapa da Educação Básica, com grandes dificuldades na compreensão, no entendimento do lê e com muitas dificuldades em se expressar na escrita.

Atualmente, a preocupação com a Língua Materna e a Matemática, se ampliou pra a área de Ciências, via o Pisa, com a inclusão da mesma nos exames de avaliação externos. Dentre os 70 países pesquisados, o Brasil é

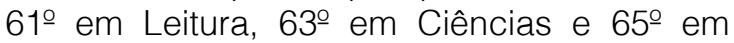
Matemática. No ensino de Ciências, destacase a preocupação dos professores com a ministração de conteúdos e não com a realização da investigação científica. Nos anos iniciais observa-se a pouca valorização, que vai desde a locação de carga horária à seleção de conteúdos, vinculados, em sua maioria, a saúde e higiene, onde conceitos de Química, Física e Biologia, que poderiam ajudam na vida do aluno são desconsiderados, caracterizando uma proposta pedagógica focada na memorização, em um ensino não investigativo, não criativo e pouco desafiador. Não são suficiente leis que "garantam" o direito a educação, faz-se necessário que essas leis se efetivem no cotidiano das escolas e se reflitam na vida dos educandos, em especial o Ensino de
Ciências para as crianças dos anos iniciais do Ensino Fundamental, foco deste estudo.

Uma práxis pedagógica voltada para o desenvolvimento e aprendizagens significativas que articulem o cuidar e educar como premissa para o Ensino de Ciências nos Anos Iniciais do Ensino Fundamental, respeitando o interesse e curiosidade que essas crianças têm pelas elementos e fenômenos da natureza, e acreditando que serão capazes de aprofundar sua compreensão crítica sobre tais coisas, ainda não é realidade, haja vista, embora a preocupação com o desenvolvimento integral das crianças desde a tenra idade seja explicitado claramente em diferentes ordenamentos legais, como por exemplo nas Diretrizes Curriculares Nacionais para a Educação Infantil, DCNEI (2009), ao destacar que as instituições de educação infantil devem promover em suas Propostas Pedagógicas, praticas e cuidados que promovam a integração entre os aspectos físicos, emocionais, afetivos, cognitivo/linguísticos e sociais da criança, entendendo que ela é um ser completo, total e indivisível e por isso precisa ser cuidada e educada pela escola. No que tange ao Ensino Fundamental, a lei estabelece o que é próprio a cada área de conhecimento: a aprendizagem da leitura, escrita, cálculo e a construção de valores e atitudes, bem como a compreensão do ambiente natural, social, da tecnologia e da política (BRASIL, 1996); observando-se que o binômico cuidar e educar é implícito, apesar de se ressaltar que a criança é um ser indissociável.

Forest \& Weiss (2003) enfatizam que para trabalharmos articuladamente o cuidar e educar devemos envolver, entre outros esforços: o estudo, a dedicação, a cooperação, a cumplicidade e, sobretudo, o amor de todos os responsáveis pelo processo de aprendizagem que é dinâmico e em constante evolução. Assim, para cuidar é preciso um comprometimento com o outro, com sua singularidade, ser solidário com suas necessidades, confiando em suas capacidades. Ora, o comprometimento com outro, no foco de nossa reflexão, implica em possibilidades de interação, especificamente no Ensino de Ciências implica na construção de uma consciência planetária, onde todos e tudo é importante, deste modo parafraseando Paulo Freire a criança se constrói como sujeito com seus pares, em seu lócus.

Evidencia-se que a concepção de cuidar e 
educar varia de cultura para cultura, de acordo com as relações que a sociedade estabelece não somente com suas crianças, mas também com seus adolescentes, jovens e adultos. Assim, não é possível dissociar o cuidar do educar, pois o desenvolvimento humano depende de aprendizagens realizadas através das interações estabelecidas entre os sujeitos, as quais, ao mesmo tempo influenciam e potencializam seu desenvolvimento individual e a construção de um saber coletivo e cultural. Para Vital Didonet (2003, p.8), "cuidar e educar são ações intrínsecas e de responsabilidade da família, dos professores e dos médicos. Todos têm de saber que só se cuida educando e só se educa cuidando".

Partindo desta proposição e da certeza de que o Ensino de Ciências é um componente indispensável na formação da criança, haja vista ser o conhecimento científico parte da cultura elaborada e fundamental para conhecer o mundo e a criança, como sujeito social, participar cada vez mais em diferentes questões, como as relativas ao meio ambiente, sendo a curiosidade por aspectos relacionados às Ciências uma das características das crianças (ZANCUL, 2004), é que refletimos acerca da ressignificação do ensino de Ciências nos anos inicias do ensino fundamental, na perspectiva de um novo olhar sobre esta criança que, mesmo sendo sujeitos de pouca idade, mas de direitos, possuem especificidades que lhes são peculiares, as quais precisam estar centradas em suas necessidades e aprendizagens, como fatores elementares de seu processo educativo.

O século $X X I$, trás para o convívio diário das crianças o conhecimento científico, seja nos meios de comunicação através de informações, jogos, aplicativos e outros, seja por meio de vivências como a possibilidade de compreender e melhorar a vida dos indivíduos, saneamento, doenças e outros, isto é, as transformações acontecem rapidamente em todos os âmbitos da sociedade, trazendo para o cotidiano das mesmas conceituações equivocadas e inversões de valores, apresentados pelo consumo excessivo e desvalorização do conhecimento.

Nesse sentido, o cuidar e o educar, se tornam premissas necessárias ao ensino de Ciências nos anos iniciais que visa reflexões práticas dos fenômenos da natureza, dos recursos naturais, do panorama natural e social promovendo a participação ativa dos alunos, desenvolvendo o caráter investigativo da Ciência e o reconhecimento do conhecimento do senso comum e de caráter científico. Para Borges (2012), o ensino de Ciências tem o papel de contribuir, principalmente, para que as crianças pensem de maneira lógica sobre os fatos do cotidiano, resolvam problemas práticos, construam hábitos saudáveis e garantam sua qualidade de vida. Em síntese, é um aprender para a vida e não meramente para cumprir metas ou programas do sistema de ensino.

Isto posto, é relevante não esquecermos do professor, suas concepções de aprendizagem, de cuidar e educar pautadas na perspectiva transdisciplinar dos conteúdos, apoiada em princípios, valores e crenças oriundos das experiências e saberes construídos ao longo da formação continuada e da práxis pedagógica, são pilares para uma docência que contribuiu para o ensino de Ciências, tornar-se significativo, fundamentado na investigação reflexiva e argumentativa, promovendo o desenvolvimento e aprendizagem das crianças.

Promover o ensino de Ciências transdisciplinar, desafia-nos a interação dos domínios disciplinares em torno de uma base mais abrangente, onde o processo de ensinoaprendizagem é construído a partir de uma nova maneira de fazer ciências, dialogando permanentemente com outros saberes no sentido de compreender a complexidade da vida e da cultura, constructos históricos próprios dos seres humanos, ricos em multidimensionalidades multireferencialidades.

Deste modo é preciso que os professores possibilitem às crianças identificar suas necessidades e priorizá-las, assim como atendê-las de forma adequada. Para que isso aconteça, de fato devemos interessarmo-nos sobre o que os educandos sentem, pensam, o que sabem sobre si e sobre o mundo, apontando à ampliação de conhecimentos que os tornarão mais potentes e autônomos. Forest \& Weiss (2003) nos chamam atenção que:

Cuidar e educar implica reconhecer que o desenvolvimento, a construção dos saberes, a constituição do ser não ocorre em momentos e compartimentados. A criança é um ser completo, tendo sua 
interação social e construção como ser humano permanentemente estabelecido em tempo integral. Cuidar e educar significa compreender que o espaço/tempo em que a criança vive exige seu esforço particular e a mediação dos adultos como forma de proporcionar ambientes que estimulem a curiosidade com consciência e responsabilidade (Forest \& Weiss, 2003, p. 2).

Assim, um ambiente de vivência que considera o tempo da experiência e não somente um tempo cronológico, expresso em simples horas, e sim de uma proposta que contribui "não apenas para que os alunos adquiram novas experiências, mas para que possam também organizá-las, construindo conceitos (BIZZO, 2007, p.52). Um tempo significativo que é construído por meio de interações com os demais sujeitos e com o ambiente, este como componente ativo da aprendizagem que respeita o contexto do grupo. Neste sentido, o sujeito emerge num processo formativo, possibilitado por relações construídas por afetos e respeito, cuja trajetória de vivências de pesquisa e encontro dialógico com o conhecimento científico instituindo-se num território propício de significados e emoções.

Observamos que as experiências passadas articuladas ao presente e ao desejo de futuro leva-nos ao encontro da discussão que Morin (2010) aponta ao não defender uma visão linear de temporalidade por acreditar na complexidade deste movimento, uma vez que existe uma interdependência entre esses momentos. Assim, considera que no descarrilhar de nossas vidas num tempo presente, passado e futuro estão imbricados concomitantemente, ou seja, "o conhecimento do presente é necessário para o conhecimento do futuro, o qual é necessário para o conhecimento do presente"(MORIN, 2010, p.14). Dessa forma, precisamos abandonar a ideia simplificadora e aparentemente evidente entre passado, presente e futuro pela concepção complexa. Em seus próprios termos:

O passado é construído a partir do presente, que seleciona aquilo que, a seus olhos é histórico, isto é, precisamente aquilo que, no passado, desenvolveu-se para produzir o presente $(2010$, p.12) [...] A tudo isso, acrescenta-se que o futuro é necessário para o conhecimento do presente. É ele que vai operar a seleção no burburinho das ações, interações, retroações que constituem o presente [...] É à luz do futuro tornando-se presente e fazendo do presente um passado que os atores principais do presente adentram na penumbra, transformam-se em comparsas, em parceiros úteis, enquanto saem da penumbra, dos bastidores, debaixo das mesas, detrás das cortinas, os atletas verdadeiros no jogo do tempo (MORIN, 2010, p.14)

Esta possibilidade de refletirmos sobre as experiências de aprendizagem a partir do conhecimento científico adensa a compreensão de tempo, como a interdependência entre passado, presente e futuro, expressa por Morin, ajudando-nos a compreender sobre a potencialidade de tempos e espaços pensados em sua complexidade; num jogo retroativo onde o presente é elemento fundante para a compreensão do passado, uma vez que, neste jogo retroativo, as experiências se sucedem permitindo novos enfoques, em cada novo presente, que modifica o passado (MORIN, 2010, p. 12).

\section{CONSIDERAÇÕES FINAIS}

Ao dialogarmos acerca do ensino de Ciências nos anos iniciais na interação com o binômio Cuidar-Educar buscamos, essencialmente, refletir a partir das necessidades básicas das crianças, quais sejam: descobrir, construir e desconstruir na busca do aprender. Evidenciamos, ainda mais a importância do Ensino de Ciências nos anos iniciais, tendo como principais elementos o cuidar e educar, na perspectiva de transdisciplinaridade, possibilitando uma educação que contribui para que as pessoas estejam atentas a questionar o moderno, o novo e o tecnológico e, ao mesmo tempo, procurem incorporar, cada vez mais, os seus interesses individuais e coletivos as novas descobertas e inovações advindas com o avanço científico, reafirmando a inclusão social e o compromisso ético com a sociedade.

Os elementos pedagógicos, como planejamento, contextualização do real, formação continuada, processo avaliativo e pesquisa, que devem possibilitar uma situação realmente considerada pedagógica encontram-se pautados na concepção de 
Ciência para os Anos iniciais, fundamentamse na participação efetiva da criança em seu processo de desenvolvimento e aprendizagem para além da escola.

Deste modo, ressaltamos que precisamos continuar respeitando, incentivando e aprimorando a curiosidade infantil, qualificando os porquês dessas crianças,

\section{REFERÊNCIAS}

[1] Bizzo, N. Ciências: fácil ou difícil? São Paulo: Editora Ática, 2007.

[2] Borges, G. L. de A. Ciências nos anos iniciais do Ensino Fundamental: fundamentos, história e realidade em sala de aula. Faculdade Estadual Paulista Júlio de Mesquita Filho, São Paulo, 2012. Disponível em: http://acervodigital.unesp.br/bitstream/123456 789/47357/1/u1_d23_v10_t01.pdf. Acesso em 17 jan. 2013.

[3] Brasil. Ministério da Educação. Secretaria de Educação Fundamental. Parâmetros curriculares nacionais: ciências naturais. 2. ed. Rio de Janeiro: DP\&A, 2000.

[4] Secretaria de Educação Fundamental. Diretrizes Curriculares Nacionais para a Educação Infantil. Brasília: MEC, 2009.

[5] Didonet, V. Não há educação sem cuidado. Revista Pátio Educação Infantil, Porto Alegre, ano 1 n.1. Abr/jul. 2003. p. 8. possibilitando que elas compreendam que a pergunta é essencial na construção do conhecimento científico, sem perder de vista a especificidade do trabalho com crianças dos anos iniciais, assim como, nos desafiarmos ao diálogo com os adolescentes e adultos buscando interagir de maneira consistente e consciente com estes sujeitos, cuidando e educando.

[6] Forest, N. A. \& WEISS, S. L. Educar e cuidar: perspectives para a prática pedagógica na educação infantil. In: Revista Leonardo Pós, vol. 1, no 3, agosto/dezembro/2003 (www.icpg.com.br/hp/revista/index.php?rp_aut $\mathrm{o}=3$, acesso em 31/07/2008)

[7] Freire, Paulo. Extensão ou comunicação? 2.ed. Rio de Janeiro: Paz e Terra, 1975.

[8] Gonçalves, M.E.R. e Carvalho A.M.P., As atividades de conhecimento físico: um exemplo relativo à sombra. Cadernos Catarinenses de Ensino de Física, 1996.

[9] Morin, E. Para onde vai o mundo? Petrópolis, Rio de Janeiro: Vozes, 2010.

[10] Souza, Giulianna Paiva V. A.; SANTOS, Elizeu A. dos; Souza JR, Airton A. de. Química para o Ensino de Ciências. Natal: Edufrn, 2011.

[11] Ancul, M. C. S. Ciências no ensino fundamental. In: Demonte, A. et al. Pedagogia Cidadã: cadernos de formação: Ciências e Saúde. São Paulo: Unesp, Pró-Reitoria de Graduação, 2004. p. 125-134. 


\section{Capítulo 2}

\section{APRENDIZAGEM BASEADA NA RESOLUCÃO DE PROBLEMAS E A ELABORAÇÃO DE FUNDAMENTAL

\section{Patrícia Regina Carvalho Ottz}

\section{Antonio Henrique Pinto}

\section{Manuella Villar Amado}

Resumo: A Aprendizagem Baseada na Resolução de Problemas (ABRP) é uma metodologia de ensino que tem apresentado potencialidades educativas para o ensino de Ciências, no que se refere ao questionamento, a investigação e a aprendizagem de novos conceitos. No Brasil, a aplicação da ABRP na Educação Básica ainda é incipiente com poucos relatos de experiências e pesquisas na área. Nesse sentido, esta pesquisa buscou analisar e classificar o nível cognitivo das questões formuladas por alunos de acordo com a classificação proposta por Dalghen e Oberg (2001) a partir de dois cenários investigativos elaborados conforme os pressupostos de Vasconcelos e Almeida (2012). Os resultados apontam que a metodologia ABRP contribuiu para a elaboração e seleção de questões relevantes para a investigação científica proposta.

Palavras chave: ensino de ciências, aprendizagem baseado em problemas, questionamento 
1. O PAPEL DO PROBLEMA NA METODOLOGIA DA APRENDIZAGEM BASEADA NA RESOLUÇÃO DE PROBLEMAS

O contexto problemático na ABRP é o ponto de partida para o processo de aprendizagem, por isso deve ser um fator de motivação, para a manutenção do interesse e atenção dos alunos. O problema tem o papel de despertar nos estudantes a elaboração de questões que serão relevantes no processo de investigação. As características de um problema na perspectiva de ABRP que precisam ser consideradas na etapa de elaboração do cenário ou contexto problemático são apresentadas em várias pesquisas (COSTA, 2013; SILVA; LEITE; PEREIRA, 2013, VASCONCELOS; ALMEIDA, 2012; MORAES, 2010; LOUREIRO, 2008). É necessário que seja instigante e significativo, de modo a despertar a curiosidade e a participação dos estudantes com a situação que será estudada, além disso, o problema precisa está inserido em um contexto real ou imaginário, desde que próximo à realidade dos estudantes. Pode ser apresentado pelo professor ou por um aluno, ao grupo ou turma, por meio de textos ou imagens, de forma que facilite a compreensão do problema.

O problema na perspectiva da metodologia ABRP não se refere a exercício com técnicas para resolver. O problema na ABRP possui um contexto, aparece durante todo o processo de aprendizagem e não visa apenas ao desenvolvimento de conceitos, mas também de procedimentos. A resolução do problema é vista como meio e não como fim, o aluno deverá recorrer aos conhecimentos prévios e a outros que terá que aprender mediado pelo professor (MORAES, 2010). Sob essa perspectiva, a contextualização do ensino de Ciências é um dos pontos principais a ser considerado na escolha do tema que irá orientar a proposta de trabalho com a metodologia ABRP. O tema além de atual deve promover o desenvolvimento de conteúdos científicos que ajudem na resolução de um problema científico ou sociocientífico. Além disso, precisa estar previsto nos documentos curriculares de Ciências em nível federal, estadual ou municipal. (VASCONCELOS; ALMEIDA, 2012).

Construir contextos problemáticos adequados e motivadores não é tarefa fácil, principalmente quando se quer um cenário na perspectiva CTSA que pressupõe que o problema forneça elementos para uma análise crítica das situações socioambientais à luz dos aspectos científicos, tecnológicos, sociais e ambientais. Além disso, o problema deve fazer parte da realidade social dos alunos, ficando bem claro as relações entre a ciência e a sociedade e suas implicações socioambientais no tema. A metodologia Aprendizagem Baseada na Resolução de Problemas (ABRP) tem se mostrado uma opção inovadora e desafiadora para o professor que adota uma abordagem sociocultural nas suas aulas. No Brasil, mais comumente chamada de Aprendizagem Baseada em Problemas sua aplicação na Educação Básica ainda é incipiente com poucos relatos de experiências e pesquisas na área, muito do que se sabe aqui baseia-se nas experiências de Portugal.

Vasconcelos e Almeida (2012), após estudo de várias propostas de ABRP apresentadas por diferentes autores, chegaram à conclusão de que todas buscam o mesmo objetivo e desenvolvem fases obrigatórias durante 0 processo ensino-aprendizagem. Os autores apresentam as fases por meio do processo cíclico da ABRP (figura 1), que se inicia pela apresentação do problema pelo professor. Em seguida, os alunos de posse de uma ficha de monitoramento do processo da ABRP que servirá apenas de caminho a ser desenvolvido, fazem o recolhimento dos fatos fornecidos pelo problema e a listagem das questões que serão investigadas. Esta pequena investigação permitirá aos alunos a elaboração de algumas hipóteses e a execução de suas previsões, que ajudarão posteriormente na construção da argumentação explicativa a ser apresentada no final da resolução do problema. 
Figura 1 - Representação do processo cíclico da ABRP

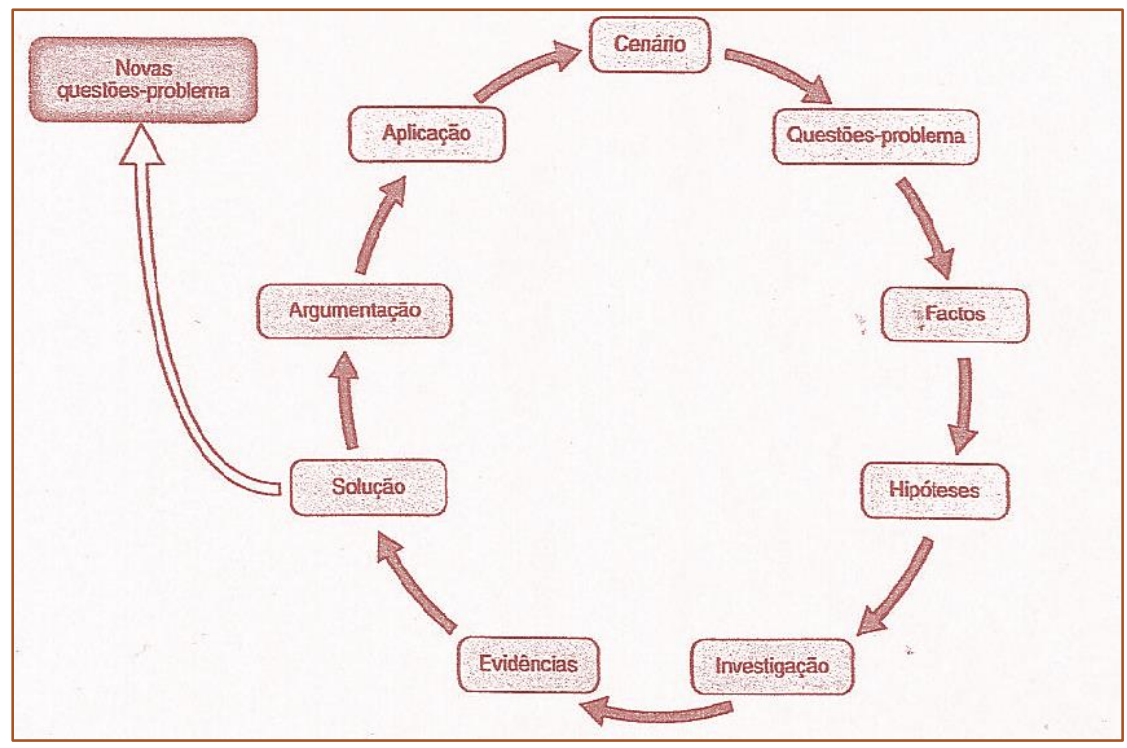

Fonte: Vasconcelos e Almeida, 2012, p. 22.

Segundo os autores supracitados, o recolhimento de fatos e a formulação de questões são fases que deverão ocorrer em grupos de quatro ou seis alunos, não devendo prosseguir a investigação sem 0 compartilhamento dos fatos e questões com a turma. Cabe ao professor mediar esse momento, pois podem surgir questões que não são pertinentes, e que, por isso, poderão ser descartadas ou até mesmo respondidas rapidamente pelos grupos. As questões que permanecerem conduzirão à busca de informações propriamente que, por sua vez, levarão à possível solução do problema. O professor acompanha o processo de grupo em grupo incentivando a participação de cada componente na busca das soluções. Cada grupo poderá dar um encaminhamento diferente no desenrolar da investigação, cabendo ao professor provocar questionamentos e reflexões na forma de pensar nos grupos.

$\mathrm{Na}$ etapa de preenchimento da ficha de monitoramento, uma das ações mais importantes a serem realizadas pelos alunos é a elaboração das questões relacionadas ao problema apresentado, pois o nível cognitivo das questões vai interferir no rumo da investigação científica. Neste sentido, a classificação proposta por Dalghen e Oberg (2001) auxilia a análise do nível cognitivo das questões elaboradas em uma investigação, autores estabeleceram uma hierarquia para as questões: das mais superficiais às mais complexas, ficando assim: enciclopédico, de compreensão, relacionais, de avaliação e procura de solução. Tal análise contribui como suporte pedagógico para o professor que está se familiarizando com a metodologia ABRP, este apoio pode acontecer por recursos didáticos, guias, livros e formação inicial/continuada, daí a importância de pesquisas na área de Educação em Ciências em todos os níveis de ensino.

Inserido numa pesquisa de mestrado intitulada 'Alfabetização Científica a partir da Aprendizagem Baseada na Resolução de Problemas: a contextualização do cultivo da mandioca no Ensino Fundamental', este trabalho tem por objetivo classificar as questões formuladas pelos alunos quanto a seu nível cognitivo, durante a aplicação de duas propostas de investigação com a metodologia ABRP. Foram criados dois cenários para 0 trabalho com a temática 'Agricultura e Alimentos', o primeiro, intitulado 'Da mandioca à farinha', e o segundo, 'O mistério do amido', para cada cenário foi elaborado um planejamento baseado na metodologia ABRP, segundo as orientações de Vasconcelos e Almeida (2012). Ao todo participaram 119 alunos do $7^{\circ}$ ano de uma escola pública localizada no município de Aracruz, (ES). 


\section{DESENVOLVIMENTO}

O primeiro problema 'Da mandioca à farinha' começa instigando no aluno as questões sociais e ambientais que envolvem o alimento farinha e o processo de sua produção por meio da agricultura familiar. Ao fazer com que os agricultores busquem informação sobre o plantio da mandioca, provocou-se nos alunos o questionamento acerca da reprodução vegetal, por sementes e estacas. O cenário do problema continua, agora trazendo como pista uma visita à aldeia indígena para observação do cultivo de mandioca e da fabricação de farinha. Nesse ponto, a intenção é despertar no aluno a curiosidade pelo contato com outra cultura, que tem na observação, uma forma diferente de compreensão da natureza.

Após o recolhimento dos fatos ou 'pistas', cada grupo passou ao levantamento de possíveis questões-problema, que foram feitas separadamente pelos grupos. A ficha de monitoramento da ABRP esteve com o grupo por vários momentos na investigação. Primeiro, para o recolhimento de fatos/pistas do problema; em seguida, na elaboração das questões-problema, e, por último, nas aulas de elaboração das soluções. Neste trabalho, optamos por deixar à vontade a elaboração das questões-problema pelos grupos, sem limitar a quantidade de questões. Após a ficha preenchida, foi necessário, fazer a leitura de todas as questões para identificar aquelas que estavam confusas, para dar uma devolutiva aos grupos, pedindo sua retirada ou reescrita.

Já na aplicação do segundo problema ' $O$ mistério do amido', os alunos são desafiados a elaborar uma explicação para o mistério da origem do amido da mandioca, combinando as leituras que fizeram sobre as observações dos índios, o experimento de Van Helmont e o experimento dos alunos. Para facilitar a compreensão da etapa de elaboração de questionamentos quanto ao problema, foi preciso exemplificar, com o trecho que citava o experimento de Van Helmont, uma vez que o problema não esclarecia como foi feito e as conclusões obtidas pelo cientista. A partir deste ponto os grupos fizeram as perguntas em folha separada, para que, na aula subsequente, fossem definidas as questões mais relevantes para a investigação. (LEITE; AFONSO, 2001).

Assim, foram criadas cinco categorias de perguntas quanto ao assunto enfatizado: o experimento de Van Helmont; a observação dos índios; o experimento dos alunos; a reserva de amido pelos vegetais; e a biotecnologia indígena. Apresentamos em slides as perguntas agrupadas à turma, combinando que eliminaríamos aquelas que não eram relevantes para a pesquisa e as que estavam mal elaboradas. Cada turma selecionou uma média de 7 a 8 questões que foram registradas na ficha de monitoramento da ABRP e que conduziriam à aprendizagem de novos conceitos científicos à medida que o problema fosse sendo resolvido.

\section{ANÁLISE DAS QUESTÕES FORMULADAS PELOS ALUNOS}

Ao final desta etapa, foi gerado um total de 20 questões diferentes sobre o problema ' $\mathrm{Da}$ mandioca à farinha'. Com base na classificação proposta por Dalghen e Oberg (2001), classificamos as questões formuladas pelos alunos quanto ao seu nível cognitivo. Segue abaixo 0 quadro com as vinte questões-problema elaboradas pelos quinze grupos, o número de vezes que cada uma aparece nas fichas e a classificação do tipo de questão. 
Quadro 1 - Classificação quanto ao nível cognitivo das questões-problema formuladas pelos grupos de alunos na ABRP 'Da mandioca à farinha'

\begin{tabular}{|c|c|c|}
\hline Questões-problema propostas pelos grupos & $\begin{array}{c}\text { № de } \\
\text { vezes que } \\
\text { aparecem }\end{array}$ & Tipos de questões \\
\hline Q.1.- Como se planta mandioca? & 12 & Questão de procura de solução \\
\hline Q 2 - Como se transforma a mandioca em farinha? & 09 & Questão de procura de solução \\
\hline Q 3 - Como se tira o veneno da mandioca? & 08 & Questão de procura de solução \\
\hline Q. 4- Como se diferencia a mandioca? & 07 & Questão de procura de solução \\
\hline Q.5 - Qual é a melhor terra para plantar mandioca? & 04 & Questão de compreensão \\
\hline Q. 6- Como o índio fez para descobrir a mandioca? & 03 & Questão de procura de solução \\
\hline $\begin{array}{l}\text { Q.7 - Quanto tempo demora para fazer a colheita } \\
\text { da mandioca? }\end{array}$ & 03 & Questão de compreensão \\
\hline $\begin{array}{l}\text { Q.8 - São utilizadas sementes nas plantações de } \\
\text { mandioca? }\end{array}$ & 03 & Questão enciclopédica \\
\hline Q.9 - A mandioca foi descoberta no Brasil? & 02 & Questão enciclopédica \\
\hline Q.10 - Como se faz a tapioca? & 02 & Questão de compreensão \\
\hline $\begin{array}{l}\text { Q.11 - Como os índios aprenderam a fazer a farinha } \\
\text { de mandioca? }\end{array}$ & 01 & Questão de compreensão \\
\hline $\begin{array}{l}\text { Q.12 - Qual é a melhor época do ano para fazer a } \\
\text { plantação de mandioca? }\end{array}$ & 01 & Questão de compreensão \\
\hline $\begin{array}{l}\text { Q.13 - A mandioca é atacada por algum tipo de } \\
\text { praga? }\end{array}$ & 01 & Questão enciclopédica \\
\hline $\begin{array}{l}\text { Q.14 - Como tem que ser o local da fabricação da } \\
\text { mandioca e da farinha? }\end{array}$ & 01 & Questão de procura de solução \\
\hline $\begin{array}{l}\text { Q.15 - Qual substância venenosa se encontra na } \\
\text { mandioca? }\end{array}$ & 01 & Questão de compreensão \\
\hline $\begin{array}{l}\text { Q.16- Por que ir às aldeias para conhecer a } \\
\text { mandioca? }\end{array}$ & 01 & Questão enciclopédica \\
\hline $\begin{array}{l}\text { Q.17- Como divulgar as fotos do passeio da aldeia } \\
\text { indígena nas escolas? }\end{array}$ & 01 & Questão compreensão \\
\hline Q. 18 - Precisa molhar todos os dias? & 01 & Questão enciclopédica \\
\hline $\begin{array}{l}\text { Q.19- Por que é necessário valorizar a história da } \\
\text { mandioca? }\end{array}$ & 01 & Questão de procura de solução \\
\hline $\begin{array}{l}\text { Q.20 - Onde buscar mais informações sobre a } \\
\text { mandioca? }\end{array}$ & 01 & Questão enciclopédica \\
\hline
\end{tabular}

Fonte: Elab. pela autora, 2014.

A princípio, as questões-problema elaboradas pelos grupos foram reunidas e analisadas de acordo com as questões previstas no planejamento da ABRP 'Da mandioca à farinha'. Observa-se que, do total de perguntas, apenas as Q1, Q2 e Q4 estavam previstas pela professora no seu planejamento, e estão entre as mais repetidas entre os grupos. Quanto às demais questões elaboradas, agrupamos de forma a verificar se estavam de acordo ou não com os objetivos pretendidos para a investigação.

As questões Q5, Q7, Q8, Q12, Q13 e Q18 mostram um interesse dos grupos em saber especificamente sobre o cultivo da mandioca, como o manejo da mandioca e controle de pragas, indo ao encontro de um dos objetivos da ABRP 'Da mandioca à farinha', o de levar o aluno a compreender a importância do cultivo da mandioca. Conhecer as etapas de fabricação da farinha de mandioca nas comunidades indígenas foi outro interesse dos alunos que aparecem nas questões Q6, Q9, Q11 e Q19.

As questões Q3 e Q15 traziam os seguintes questionamentos: 'Como tirar o veneno da mandioca?' e 'Qual a substância venenosa que se encontra na mandioca? Ambas permaneceram na investigação, pois possibilitam 0 trabalho com conteúdos conceituais ligados ao ensino de química, despertando a curiosidade de muitos alunos quanto à pesquisa sobre a toxicidade da planta mandioca. De todas as questões 
propostas, apenas as Q16, Q17 e Q20 apresentavam um baixo nível cognitivo, pois tinham respostas no próprio problema.

Entre todas as questões-problema, a questão Q14 chama atenção pelo questionamento crítico, pouco presente nas demais. "Como tem que ser o local da fabricação da mandioca e farinha?" A questão leva à reflexão sobre as condições sanitárias e higiênicas que deveria ter o local onde se faz a fabricação de alimentos que serão destinados ao consumo humano. Uma questão socioambiental que amplia a discussão em sala de aula, principalmente após a visita dos alunos à casa de farinha.

De modo geral, as questões levantadas pelos grupos estão de acordo com a maioria dos objetivos específicos propostos no planejamento da ABRP 'Da mandioca à farinha', além de favorecerem a busca de informações para resolver o problema proposto, alcançando uma das finalidades da metodologia ABRP. Entretanto, nenhuma questão proposta levava para a discussão nos grupos sobre as vantagens e desvantagens da principal forma de reprodução da mandioca, alertando para a necessidade da conservação da diversidade genética.

Do total de questões formuladas, apenas seis foram classificadas como do tipo 'Enciclopédicas', que corresponde ao nível cognitivo mais baixo de acordo com a classificação proposta por Dalghen e Oberg (2001), o que torna a maioria das questões adequadas com o ensino orientado para a ABRP (DOURADO; LEITE, 2010), por exigirem uma explicação mais complexa.

Não houve nenhuma questão do tipo 'Relacional', e sete são do tipo de 'Compreensão', o que significa que o problema provocou a curiosidade dos alunos para a compreensão de conteúdos conceituais e procedimentais em relação ao tema. Outras sete questões são do tipo 'Procura de solução', que significa o nível mais elevado na hierarquia proposta para as questões, pois ajudam na compreensão de um problema maior e mais complexo, cuja resposta exige solução deste problema.

Ao final da fase de elaboração das questões na ABRP 'O mistério do amido' foram selecionadas 09 (nove) questões, sendo que as três últimas estavam contidas no próprio problema apresentado; a pedido da professora, também foram objeto de pesquisa dos alunos todas as questões registradas na ficha de monitoramento. Com base na classificação proposta por Dalghen e Oberg (2001), podemos classificar as questões formuladas pelos alunos quanto ao seu nível cognitivo. Segue no quadro 2 com as questões-problema selecionadas pelos grupos:

Quadro 2 - Classificação quanto ao nível cognitivo das questões-problema formuladas pelos grupos de alunos na ABRP 'O mistério do amido'

\begin{tabular}{|c|c|c|}
\hline Número & Questões-problema & Tipos de Questões \\
\hline Q1. & $\begin{array}{c}\text { Como foi o experimento de Van Helmont? E quais } \\
\text { as suas conclusões? }\end{array}$ & Questão relacional \\
\hline Q2. & $\begin{array}{l}\text { Será que só as plantas é que têm amido ou será } \\
\text { que os animais também têm reservas de amido? }\end{array}$ & Questão de procura de solução \\
\hline Q3. & $\begin{array}{c}\text { Qual é o porquê do aumento da massa dos } \\
\text { vegetais? }\end{array}$ & Questão de procura de solução \\
\hline Q4. & $\begin{array}{c}\text { Por que só quando os cipós da mandioca-mãe } \\
\text { ficavam expostos ao sol, elas rebrotavam as } \\
\text { raízes grossas? }\end{array}$ & Questão de procura de solução \\
\hline Q5. & O que é clorofila? & Questão de compreensão \\
\hline Q6. & O que tem a ver o amido com a fotossíntese? & Questão relacional \\
\hline Q7. & Vocês concordam com a hipótese dos alunos? & Questão contida no problema \\
\hline Q8. & $\begin{array}{l}\text { A que conclusões se pode chegar com os } \\
\text { resultados apresentados pelos alunos? }\end{array}$ & Questão contida no problema \\
\hline Q9. & $\begin{array}{c}\text { Como será que a terra ficou após contato com a } \\
\text { solução de iodo? }\end{array}$ & Questão contida no problema \\
\hline
\end{tabular}

Fonte: Elab. pela autora, 2014. 
Podemos observar que nenhuma questão formulada pelos alunos é do tipo questão enciclopédica, isto é, que exige apenas respostas diretas e simples, o que torna todas as questões adequadas com 0 ensino orientado para a ABRP (DOURADO; LEITE, 2010), pois envolve um maior nível cognitivo tanto na sua elaboração, quanto também na construção de respostas mais complexas. Do total de seis questões, a metade é do tipo 'Procura de Solução', significando o nível máximo na hierarquia proposta para as questões, pois procuram compreender as partes de um problema maior e mais complexo, com resposta que exigem primeiramente a resolução do problema. Podemos utilizar o exemplo da Q1:"Será que só as plantas é que têm amido ou será que os animais também têm reservas de amido?". Ao buscar a resposta para a origem do amido da mandioca, os alunos vão aprender que as plantas, como a mandioca, conseguem fabricar seu próprio alimento, a glicose, e armazenar nas suas raízes, em forma de amido, capacidade que os animais não possuem.

Quando comparamos as questões elaboradas pelos alunos com as questões elaboradas previamente pelo professor, todas estão previstas no planejamento, escritas de outra maneira, mas com a mesma intenção na busca de soluções. Podemos afirmar que estão adequadas com o problema e com os objetivos previstos na ABRP (LEITE; AFONSO, 2001).

\section{REFERÊNCIAS}

[1] Costa, Cíntia. A Aprendizagem Baseada na Resolução de Problemas e a formulação de questões a partir de cenários disciplinares e transdisciplinares: um estudo centrado nas Ciências e na Geografia. In: Encontro sobre educação em ciências através da aprendizagem baseada na resolução de problemas. Atas. Instituto de Educação. Universidade do Minho, 2013, p. 149-160.

[2] Dahlgen, M. \& OBERG, G. Questioning to learn and learning to question: structure and function of problem based learning scenarios in environmental science education. Higher Education, 41, 2001, 263-282.

[3] Dourado, Luís, LEITE, Laurinda. Questionamentos em manuais escolares de ciências: que contributos para a aprendizagem baseada na resolução de problemas da 'sustentabilidade na Terra'. Boletín das Ciencias (ENCIGA), n.71, nov., 2010.

\section{CONSIDERAÇÕES FINAIS}

Observamos que o questionamento teve espaço dentro da metodologia ABRP, exigindo do professor uma postura dialógica durante todas as etapas do ciclo tutorial. A elaboração das questões envolvendo o problema foi um momento marcado por mudanças na postura também do aluno, que, de receptor passivo do conhecimento, passou a assumir uma postura ativa e participativa na sua construção. A elaboração das próprias perguntas que conduziram à investigação favoreceu aos alunos que participaram da primeira proposta um momento mais interessante e desafiador, fazendo-os sentir falta daquilo que não sabe.

Quando analisamos o nível cognitivo das vinte questões elaboradas para o primeiro problema, 07 são do tipo 'Procura de solução', 07 de 'Compreensão' e 06 do tipo 'Enciclopédicas'. Quanto ao segundo cenário, foram seis questões selecionadas, das quais a metade como do tipo 'Procura de solução', duas 'Relacional' e uma de 'Compreensão'. Esses resultados mostram que houve uma participação significativa na elaboração das questões pelos alunos e que elas apresentaram um maior nível cognitivo, exigindo reflexão e discussão na busca de resposta e sendo adequadas ao ensino orientado para a ABRP (DOURADO; LEITE, 2010).

[4] Leite, Laurinda, AFONSO, Ana Sofia. Aprendizagem Baseada na Resolução de Problemas: Características, organização e supervisão. Boletín das Ciencias, ENCIGA, n.48, 2001, p.253-260.

[5] Loureiro, Ismênia Maria Gomes. A aprendizagem baseada na resolução de problema e a formulação de questões a partir de contextos problemáticos: um estudo com professores e alunos de Física e Química. Dissertação de mestrado. Instituto de Educação. Universidade do Minho, Portugal, 2008.

[6] Moraes, Jerusa Vilhena. A alfabetização científica, a resolução de problemas e o exercício da cidadania. Uma proposta para o ensino de geografia. Tese (Faculdade de Educação) Universidade de São Paulo, São Paulo, SP, 2010.

[7] Silva, Marisa; Leite, Laurinda; PEREIRA, Alexandra. A resolução de problemas sóciocientíficos: que competências evidenciam os alunos de 7ano? In: ENCONTRO SOBRE EDUCAÇÃO EM CIÊNCIAS Através Da 
Aprendizagem Baseada $\mathrm{Na}$ Resolução De Problemas. Atas. Instituto de Educação. Universidade do Minho, 2013, p. 186-198.

[8] Vasconcelos, Clara; Almeida, Antonio. Aprendizagem Baseada na Resolução de
Problemas no Ensino das Ciências: Propostas de trabalho para Ciências Naturais, Biologia e Geografia. Porto, Portugal: Porto Editora, 2012. 


\section{Capítulo 3}

\section{INDICADORES DE INTERDISCIPLINARIDADE EM UM GRUPO DE ESTUDOS: UMA REFLEXÃO AO ENSINO DE TEMAS AMBIENTAIS NA FORMACCÃO INICIAL DE PROFESSORES}

\section{Giselle Alves Martins}

\section{Paula de Oliveira Souza}

Gabriel dos Santos Paulon

Fernanda da Rocha Brando

\section{Taitiâny Kárita Bonzanini}

Resumo:O objetivo deste trabalho é apresentar as contribuições sobre a criação de um grupo de estudos interdisciplinares, voltado às questões ambientais, na formação inicial de professores de Ciências Naturais. A construção das atividades do grupo foi norteada por cinco indicadores elaborados pelos pesquisadores com base na literatura sobre as principais características da interdisciplinaridade no contexto do ensino. As atividades realizadas foram: quatro seminários teóricopráticos sobre questões ambientais e a preparação de um jardim comestível. Os dados coletados por meio dessas atividades permitem inferir que a intervenção complementar à formação inicial dos estudantes contribuiu positivamente aos futuros professores, favorecendo a formação de sujeitos mais críticos e reflexivos, preparados para debaterem questões que envolvam, além de conteúdos científicos, diferentes aspectos como políticos, econômicos, sociais e ambientais.

Palavras-chave: Educação Ambiental, Interdisciplinaridade, Proposta didática 


\section{INTRODUÇÃO}

No Brasil, historicamente existe uma educação onde os currículos são fragmentados e desarticulados, as disciplinas são estudadas de forma isolada e sem integração (LAPA et al.,2015). Essa realidade pode ser observada em todos os níveis de ensino e reflete na formação de professores e alunos, comprometendo o pensamento crítico (PIRES, 1998) e formando sujeitos pouco preparados para enfrentar as demandas da sociedade atual, que exigem uma formação interdisciplinar.

Em termos gerais, a formação interdisciplinar de professores pode ser compreendida mediante duas ordenações: a científica e a social (FOUREZ, 2001; FAZENDA, 2008). A ordenação científica considera que a formação deve ser comprometida com a cientificidade disciplinar, sendo que as disciplinas precisariam ser analisadas de acordo com os saberes e conceitos que a ciência abrange. A ordenação social considera que os saberes científicos interdisciplinares teriam que estar de acordo com as exigências da sociedade para que sejam mais práticos, uma resposta para lidar com as situações que não competem exclusivamente ao âmbito educacional e científico. Uma terceira ordenação, denominada interacional, está voltada para a realidade de formação de professores no Brasil. Leva em consideração as duas primeiras e busca um 'saber interdisciplinar', ou seja, a inclusão da experiência docente, sua intencionalidade e funcionalidade diferenciando o contexto científico do profissional e do prático (LENOIR et al., 2001).

Diante um sistema educacional que é julgado e analisado como deficiente, a interdisciplinaridade pode ser utilizada como ferramenta para entendimento de mundo; pode ser entendida como uma atitude ousada e de busca por conhecimento, envolvendo a cultura de formação dos professores (FAZENDA, 2008); e pode ser vista como uma barreira epistemológica que ainda deve ser superada no processo formativo de educadores (INFANTE-MALACHIAS, 2011).

Considerada uma área do conhecimento interdisciplinar, a Educação Ambiental (EA) trata as questões ambientais e humanas de forma inter-relacionada e integrada (COIMBRA, 2005). É definida pelo Ministério do Meio Ambiente como:
Uma dimensão da educação, uma atividade intencional da prática social, que deve imprimir ao desenvolvimento individual um caráter social em sua relação com a natureza e com os outros seres humanos, visando potencializar essa atividade humana com a finalidade de torná-la plena de prática social e de ética ambiental (BRASIL, 2012).

Devido às dificuldades de um ensino interdisciplinar na formação inicial de professores de Ciências, bem como a importância da EA como eixo transversal no ensino, o presente trabalho, parte de uma pesquisa mais ampla, tem como objetivo apresentar as contribuições sobre a criação de um grupo de estudos interdisciplinares, voltado às questões ambientais, na formação inicial de professores de Ciências Naturais. Busca responder a seguinte pergunta: Como a criação de um grupo de estudos interdisciplinares pode contribuir para a formação inicial de professores de Ciências aptos a enfrentar as demandas ambientais atuais?

O trabalho descreve uma metodologia didática visando uma formação interdisciplinar no fazer docente a partir da compreensão abrangente e integrada das Ciências da Natureza. Ao mesmo tempo, visa à formação de um profissional com postura intelectual crítica e reflexiva, preparado para orientar e estimular seus alunos ao aprendizado significativo das ciências.

A perspectiva metodológica é de abordagem qualitativa caracterizada por um plano de investigação, uma estrutura para a tomada de decisões e estabelecimento de ações, o que permite tomar tarefas e atividades aparentemente isoladas e enquadrar em um conjunto, integrando esforços 'separados' para uma finalidade comum (PATTON, 2002). Descrever os principais temas de investigação qualitativa constitui uma estratégia coerente para a investigação qualitativa, que inclui suposições fundamentais e ideais epistemológicos (PATTON, 2002).

\section{DESENVOLVIMENTO}

O grupo de estudos é composto por pesquisadores e participantes selecionados mediante inscrição online, tendo como prérequisito alunos de cursos de licenciatura em 
Ciências Biológicas, Química, Pedagogia e Ensino de Ciências (EAD) de uma universidade pública do Estado de São Paulo.

As atividades foram realizadas em um laboratório didático da universidade e ocorreram semanalmente, em encontros de uma hora e meia de duração, durante dois meses do segundo semestre de 2016. Foi composto por quatro seminários teóricopráticos sobre temas como estética, mudanças climáticas, recursos hídricos e biodiversidade, além da construção de um jardim comestível. Todas as atividades foram áudio gravadas para coleta de dados mediante assinatura do Termo de Consentimento Livre e Esclarecido (TCLE) aprovado em reunião do Comitê de Ética em Pesquisa (CAAE: 66807416.1.000.5395).

O processo de criação e desenvolvimento do grupo está descrito em duas etapas:

\section{I) INDICADORES DE}

\section{INTERDISCIPLINARIDADE A PRIOR/}

Elaboração de cinco indicadores de interdisciplinaridade utilizadas tanto para a construção das atividades propostas quanto para as análises futuras de todos os dados coletados na pesquisa mais ampla. Ao classificar os elementos da pesquisa em categorias, se investiga o que cada um deles tem em comum com os outros, e passa-se a organizar os dados brutos (BARDIN, 2011). Seguiu-se a categorização proposta por Bardin (2011), a partir de características sobre interdisciplinaridade (FAZENDA, 2008; CANIATO, 2011; SANTOS, 2011), denominadas como indicadores principais de uma proposta interdisciplinar, lembrando que não há um consenso sobre o melhor formato de uma abordagem pedagógica interdisciplinar das Ciências Naturais (SANTOS, 2011). Por meio de reuniões anteriores às intervenções, cada palestrante tomou ciência dos indicadores (Tabela 1), instrumento guia para a construção de suas atividades e que serão retomados em futuras análises. Foi definido o tipo de abordagem a ser adotada nos seminários e as estratégias didáticas utilizadas, visando provocar discussões entre os participantes e garantir o andamento e execução das atividades práticas.

Tabela 1. Categorias procedimentais da prática interdisciplinar elaboradas a priori

\begin{tabular}{|c|c|}
\hline $\begin{array}{l}\text { Indicadores de } \\
\text { Interdisciplinaridade }\end{array}$ & $\begin{array}{l}\text { Descrição dos procedimentos adotados pelos palestrantes durantes } \\
\text { as atividades }\end{array}$ \\
\hline $\begin{array}{l}\text { 1-Construção } \\
\text { Conhecimento }\end{array}$ & $\begin{array}{l}\text { Conduzir o processo de forma provocativa, por meio de atividade } \\
\text { instigante, para a construção de argumentos pelos participantes }\end{array}$ \\
\hline $\begin{array}{l}\text { 2-Análise do } \\
\text { conhecimento prévio }\end{array}$ & $\begin{array}{l}\text { Estimular os participantes para revisão de conceitos prévios e relação } \\
\text { com as atividades propostas }\end{array}$ \\
\hline $\begin{array}{l}\text { 3-Análise } \\
\text { desempenho }\end{array}$ & $\begin{array}{l}\text { Registrar o processo de aprendizado dos participantes por meio da } \\
\text { participação nas discussões, avaliando qualitativamente seu } \\
\text { desempenho }\end{array}$ \\
\hline 4-Cooperativismo & $\begin{array}{l}\text { Estimular a leitura e discussão em grupo e a integração entre } \\
\text { participantes }\end{array}$ \\
\hline 5-Intervencionismo & $\begin{array}{l}\text { Conduzir e intervir na discussão para acrescentar e orientar os } \\
\text { participantes de forma integradora }\end{array}$ \\
\hline
\end{tabular}




\section{II) CONSTRUÇÃO DOS SEMINÁRIOS TEÓRICO-PRÁTICOS E DO JARDIM COMESTÍVEL COMO INSTRUMENTO DIDÁTICO}

- Seminário 1: A importância da Estética e a Educação Ambiental (EA)

Objetivo: Discutir o conceito de estética como ferramenta ao ensino e entender as formas como os seres humanos respondem aos fenômenos naturais por meio da estética peirceana.

Referencial teórico e estratégia didática (Rt/Ed): O seminário abordou a filosofia de Charles Sanders Peirce (1839 - 1914), explorando o conceito de estética que vai além da ideia de beleza, remetendo ao admirável que leva à busca pelo conhecimento. Discutiu-se como a estética poderia ser usada na EA para sensibilizar os educandos e a sociedade em relação às questões ambientais de forma geral. Para o levantamento de conhecimento prévio e para gerar discussões foi sugerido que os estudantes respondessem as perguntas: $O$ que é ambiente? Qual a relação da EA com a sua área de trabalho/estudo?Quais foram as suas experiências pessoais com a EA?

\section{- Seminário 2: Mudanças Climáticas}

Objetivo: Discutir problemas causados pelas mudanças climáticas por meio da tomada de decisões.

(Rt/Ed): O seminário apresentou brevemente como as mudanças no clima vêm ocorrendo na Terra, como um processo natural ao longo da história do planeta e atualmente como consequência das ações antrópicas.

Foi simulada uma reunião entre países interessados em frear as consequências de uma intervenção antrópica no clima. Os participantes foram divididos em três grupos representantes de países fictícios com características específicas: $\mathrm{A}=$ pequena extensão territorial, importador de recursos naturais, muito industrializado, paisagens altamente antropizada, baixa porcentagem de vegetação nativa, alto índice de IDH, problemas econômicos como alta taxa de desemprego e elevadas taxas de inflação; B = grande extensão territorial, exportador de muitos recursos naturais, economia dependente da exportação, dois biomas com espécies endêmicas, inúmeros serviços ecológicos ao planeta, médio IDH, perspectiva de crescimento nos próximos 5 anos e grave crise política como denúncias de corrupção no atual governo; $\mathrm{C}=$ pequena extensão territorial, economia altamente dependente da exportação, exporta muitos recursos minerais e naturais, paisagens naturais muito devastadas, graves problemas sociais como grande deficiência no sistema educacional.

Durante a reunião os representantes dos países fictícios discutiram como suas ações colaborariam para frear as consequências de uma intervenção antrópica no clima e deveriam entrar num acordo para decidir quais medidas seriam tomadas para causar menos impactos futuramente. Responderam as seguintes perguntas: $O$ que mais valorizo? Por quê? Quais os meus objetivos como nação? Como colaboro com a questão das mudanças climáticas? Como agravo as consequências das mudanças climáticas? Do que eu abriria mão para diminuir o impacto no clima? Do que não abriria mão? Após discussão e acordos estabelecidos deveriam responder: Quais os consensos alcançados? Quais as faltas de consenso? Por quê? Você como educador: Quais os pontos (social, ambiental, econômico e político) levaria em consideração para discutir na sala de aula? Quais pontos são considerados de maior dificuldade na hora de promover uma discussão desse tipo junto com os alunos? Por quê?

\section{- Seminário 3: Recursos Hídricos}

Objetivo: Estimular a reflexão crítica sobre as consequências geradas a partir da transposição do Rio Piumhi (MG), levantando em consideração aspectos econômicos, sociais, políticos e ambientais, e discutir ações para minimizar os impactos desse processo.

(Rt/Ed): O tema foi tratado por meio de apresentação do caso da transposição do Rio Piumhi, ocorrida no final da década de 1950 e início da década de 1960, para a construção de uma hidrelétrica levando a mudança do curso do rio. Foram tratadas as consequências dessa intervenção por meio das percepções de moradores que acompanharam o processo da atual ausência de mata ciliar e assoreamento do Rio Piumhi, a situação da fauna de peixes pertencentes à bacia do Rio Grande que foi transposta para a bacia do rio São Francisco.

Os participantes foram estimulados a pensarem e discutirem sobre os prós e os contras desse projeto e as ações mitigadoras para as consequências geradas. Ao final, os 
participantes construíram um mapa conceitual sendo pré-definidos alguns termos: ambiental, social, econômico e a EA.

- Seminário 4: Conservação da Biodiversidade

Objetivo: Compreender conteúdos sobre conservação e preservação da biodiversidade em seus diferentes níveis para a tomada de decisões envolvendo atores sociais.

(Rt/Ed): O seminário apresentou uma contextualização sobre biodiversidade e seus níveis, explicitando diferenças entre preservação e conservação. Foram tratados os tipos de unidades de conservação previstos na legislação brasileira e as diferenças entre unidades de proteção integral e de uso sustentável, buscando um entendimento sobre a necessidade em conservar a biodiversidade.

A parte prática se deu por meio de uma situação hipotética que envolvia a expansão de uma unidade de conservação. Os participantes foram divididos em quatro grupos representantes de setores da sociedade: instituto governamental de gestão responsável por executar a expansão e gestão de um Parque Nacional (PARNA); população residente na área de expansão do parque, responsável pelo resgate e memória da história de vida da população; empresários das siderúrgicas, responsáveis por elaborar um projeto de uso dos recursos naturais da área; educadores ambientais participantes de uma ONG, responsáveis pela conservação das espécies ameaçadas de extinção.

Foram feitas três rodadas de discussão:

1. Formação de aliados, agregando grupos com interesses comuns;

2. Identificação de grupos de conflitos que deveriam tentar negociar um acordo;

3. Tomada de decisões após todas as discussões e acordos em que os grupos deveriam entrar em um consenso para decidir sobre a expansão do PARNA.

- Construção do jardim comestível: "O jardim permacultural"

Objetivo: Sistematizar de forma prática os conteúdos tratados durante as atividades teórico-práticas.

(Rt/Ed): a ferramenta utilizada para a construção do jardim foi a Permacultura, termo criado por Bill Mollisson e David Holmgren em 1978 para definir um tipo de agricultura e cultura permanente. Nesse projeto, a construção do jardim deu-se em três etapas:

1. Exposição teórica sobre Permacultura e utilização de um roteiro de planejamento para reconhecimento da área por meio de observações e anotações sobre o formato da área de plantio, medição do tamanho, localização dos pontos sombreados, fauna e flora presentes; planejamento do design e sugestões de plantas;

2. Plantio das mudas e sementes, mudas e plantas alimentícias não convencionais (PANCs).

3. Registro em tabela sobre a situação de cada planta ou semente plantada para terem contato com o resultado do plantio.

\section{ANÁLISE SOBRE A FORMAÇÃO DO GRUPO}

O grupo contou com a participação de 12 estudantes dos cursos de licenciatura em Ciências Biológicas, Química, Pedagogia e Ensino de Ciências EAD resultando num total de $10 \mathrm{~h}$ e $30 \mathrm{~min}$ de atividades.

Ao longo das atividades as características de interdisciplinaridade estiveram presentes (Tabela 2) tendo sido anotados os indícios dos relatos dos participantes, anotados em cadernos de campo dos pesquisadores. 
Tabela 2. Indício da presença das categorias de interdisciplinaridade durante as atividades do grupo de estudos (Legenda: S=seminário)

\begin{tabular}{|c|c|c|}
\hline Cate & Atividades & Indícios da presença das categorias durante as atividades \\
\hline \multirow{5}{*}{$\begin{array}{l}\text { 1. Construção } \\
\text { de } \\
\text { conhecimento }\end{array}$} & S1 & $\begin{array}{l}\text { A estética pode ser usada como ferramenta de sensibilização à conservação } \\
\text { do meio, algo desconhecido pelos participantes }\end{array}$ \\
\hline & S2 & $\begin{array}{l}\text { O tratamento sobre conflitos de interesse justificou a complexidade da } \\
\text { atividade }\end{array}$ \\
\hline & S3 & $\begin{array}{l}\text { O conceito de "ação mitigadora" despertou o interesse dos participantes por } \\
\text { ser um termo chave na discussão de questões ambientais }\end{array}$ \\
\hline & S4 & $\begin{array}{l}\text { A atividade foi formativa na distinção dos conceitos preservação e conservação } \\
\text { e gerou debates para a tomada de decisão com diferentes atores sociais }\end{array}$ \\
\hline & Jardim & $\begin{array}{l}\text { A ideia de Permacultura foi aceita apesar do pouco tempo disponível para } \\
\text { aprofundamento teórico }\end{array}$ \\
\hline \multirow{5}{*}{$\begin{array}{l}\text { 2. Análise de } \\
\text { conhecimento } \\
\text { prévio }\end{array}$} & S1 & $\begin{array}{l}\text { Durante a intepretação de obras de arte foram recordados filmes e livros (A } \\
\text { pele que habita, Iracema) entre outras experiências vivenciadas anteriormente }\end{array}$ \\
\hline & S2 & $\begin{array}{l}\text { A atividade exigiu algumas noções prévias de geociência o que tornou o } \\
\text { debate mais complexo }\end{array}$ \\
\hline & S3 & $\begin{array}{l}\text { Uma das participantes já conhecia a área do estudo de caso o que contribuiu } \\
\text { para relatos sobre o turismo na região }\end{array}$ \\
\hline & S4 & $\begin{array}{l}\text { Diversos equívocos acerca dos termos conservação e preservação cometidos } \\
\text { principalmente pela mídia foram desmitificados }\end{array}$ \\
\hline & Jardim & $\begin{array}{l}\text { Alguns participantes reportaram que nunca tiveram contato com plantio e outra } \\
\text { participante que não tinha aprendido sobre a posição do sol. }\end{array}$ \\
\hline \multirow{5}{*}{$\begin{array}{l}\text { 3. Análise de } \\
\text { desempenho }\end{array}$} & S1 & $\begin{array}{l}\text { Inicialmente os participantes estavam tímidos, sem muita interação e após } \\
\text { alguns momentos de descontração começaram a responder as perguntas com } \\
\text { desenvoltura }\end{array}$ \\
\hline & S2 & $\begin{array}{l}\text { Exigiu dos participantes lidar com diversos aspectos para chegarem num } \\
\text { consenso. Houve avanços na proposição de acordos de cooperação entre os } \\
\text { países }\end{array}$ \\
\hline & S3 & $\begin{array}{l}\text { A discussão sobre a transposição do Rio Piumhi despertou o interesse dos } \\
\text { participantes, favorecendo ampla participação e discussão }\end{array}$ \\
\hline & S4 & $\begin{array}{l}\text { Como representantes dos atores sociais na tomada de decisões os } \\
\text { participantes discutiram aspectos econômicos, ambientais, sociais e políticos }\end{array}$ \\
\hline & Jardim & $\begin{array}{l}\text { A fase de planejamento do plantio não foi concluída pelos participantes pela } \\
\text { falta de experiência atrelada ao tempo de atividade. No dia do plantio houve } \\
\text { maior envolvimento e participação de todos }\end{array}$ \\
\hline \multirow{5}{*}{$\begin{array}{l}4 . \\
\text { Cooperativismo }\end{array}$} & S1 & $\begin{array}{l}\text { No decorrer da atividade, os participantes complementavam as respostas uns } \\
\text { dos outros }\end{array}$ \\
\hline & S2 & $\begin{array}{l}\text { Diante da necessidade de acordos, os participantes se ajudaram considerando } \\
\text { o interesse de cada país }\end{array}$ \\
\hline & S3 & $\begin{array}{l}\text { A construção do mapa conceitual foi coletiva e os participantes precisaram } \\
\text { chegar em um consenso sobre esta construção }\end{array}$ \\
\hline & S4 & $\begin{array}{l}\text { Representando diferentes atores sociais, os participantes precisaram interagir e } \\
\text { formar alianças para a tomada de decisão }\end{array}$ \\
\hline & Jardim & $\begin{array}{l}\text { Os participantes se revezaram durante a abertura de covas, colocação do } \\
\text { adubo e plantio }\end{array}$ \\
\hline \multirow{5}{*}{$\begin{array}{l}5 . \\
\text { Intervencionismo }\end{array}$} & S1 & $\begin{array}{l}\text { A discussão provocativa adotada pela palestrante motivou a participação } \\
\text { durante todo tempo }\end{array}$ \\
\hline & S2 & $\begin{array}{l}\text { Devido às dificuldades conceituais, a palestrante sugeriu alguns caminhos de } \\
\text { como realizar os acordos entre os países }\end{array}$ \\
\hline & S3 & $\begin{array}{l}\text { Esclarecimentos sobre o tema pois durante a construção do mapa conceitual } \\
\text { as interações foram apenas entre os participantes }\end{array}$ \\
\hline & S4 & $\begin{array}{l}\text { Por meio da observação participativa, a palestrante guiou a atividade apoiando } \\
\text { as decisões tomadas, mas sem interferir nas estratégias dos participantes }\end{array}$ \\
\hline & Jardim & A atividade foi colaborativa e cooperativa em prol de sua construção \\
\hline
\end{tabular}


Iniciando as atividades com o tema "Estética e Educação Ambiental", provocamos discussões a respeito de um dos inúmeros motivos para estudos mais voltado à contemplação do meio ambiente belo e natural. Segundo relatos, a perspectiva foi diferenciada sendo muitas vezes desconsiderada no ensino.

No seminário 2 verificamos algumas divergências de opiniões: algumas entendem a necessidade de se abordar os diferentes aspectos que perpassam os problemas globais, outros reconhecem a dificuldade de inter-relacionar esses temas, por causa da falta de conhecimento, do atual modelo econômico capitalista e de direcionar o olhar dos estudantes às decisões que visem lucros. A atividade estimulou as interações discursivas e permitiu que os participantes assumissem 0 posto de tomadores de decisões como representantes das demandas dos próprios países, mas também responsáveis pelos acordos envolvendo demandas de outros países, gerando conflitos de interesse (categoria 5 - Tabela 2)

Segundo Jacobi (2011), as discussões no contexto de ensino que envolvem as mudanças climáticas ainda estão no início, buscando sua identidade e tendo como principais barreiras a busca dos países por competitividade econômica, a falta de comprimento das políticas públicas com o tema e de preparo dos docentes para trabalhar a Educação para o Desenvolvimento Sustentável para além do modo estritamente científico e comportamentalista.

O tema do seminário 3 foi novidade para a maioria dos participantes que desconheciam aspectos sobre a transposição de um rio, seus benefícios e consequências. Após a apresentação oral foi proposta a construção coletiva de um mapa conceitual (categoria 4 Tabela 2).

Para Moreira (2011), o mapa conceitual é uma ferramenta para organizar e representar o conhecimento utilizado para indicar relações entre conceitos. É composto por conceitos, proposições, frases ou palavras de ligação, o que torna possível investigar conhecimentos prévios e a apropriação de conhecimentos adquiridos.

Em depoimentos apresentados pelos participantes verifica-se que o objetivo da atividade foi cumprido, pois favoreceu a reflexão acerca não somente dos impactos ambientais, mas também sobre a tomada de decisões que requerem pensar até onde o progresso econômico e tecnológico é pertinente.

No seminário 4 os estudantes participaram de uma atividade competitiva, mas ao mesmo tempo, cooperativa. Cada grupo precisou levar em consideração, além dos próprios interesses, os interesses daqueles que iriam formar aliança e daquele que seria o grupo de conflito. Um fator positivo para os participantes foi que a tomada de decisão se trata de uma estratégia diferente quando comparada à abordagem teórico-disciplinar, pois envolve inúmeras áreas, que devem dialogar com posicionamentos, necessidades e interesses distintos. Tendo em vista a perda da biodiversidade com a extinção de várias espécies, principalmente com o avanço da agropecuária e indústria farmacêutica, tornam-se necessários o incentivo e a prática de políticas públicas que envolvam sua proteção. A EA se conecta com a atividade de preservação, recuperação e conservação de biomas e ecossistemas naturais da Terra por meio da Política Nacional de Educação Ambiental (PNEA) e a Política Nacional de Biodiversidade (PNB) (PEDRINI, 2006). A abordagem pedagógica realizada nessa atividade foi importante por proporcionar diferentes padrões de interações discursivas em uma atividade que exigia dos participantes a argumentação, raciocínio lógico e conhecimento científico (SILVA \& MORTMER, 2009).

Ao final desse primeiro ciclo de atividades, a construção de um jardim tendo como base teórica a Permacultura serviu como instrumento didático ao ensino interdisciplinar por possibilitar diferentes abordagens com variados focos de estudo. Stumpf (2012) analisou as percepções dos educadores referente a permacultura como estratégia de EA escolar, realçando: a facilitação da aprendizagem; a contribuição para o desenvolvimento de outros tipos de inteligência, não somente a cognitiva; o potencial da permacultura para o ensino transdisciplinar; a mudança comportamental por promover o cooperativismo; a valorização do ambiente; a contribuição para a visão sistêmica e o aproveitamento de recursos e geração de produtos. Silva (2010) sugere a busca de ideias fora do conhecimento hegemônico e das práticas instituídas, encontrando a solução de problemas através do engajamento efetivo, aproximando os conhecimentos científicos e tradicionais. 
Nas discussões verificou-se a importância dada à interdisciplinaridade $e$ à $E A$ no ambiente escolar, pois ambas colocadas em prática podem ser consideradas ferramentas na formação de professores e alunos, favorecendo o desenvolvimento do espírito crítico e de sujeitos mais preparados para debaterem questões que envolvam diferentes aspectos como políticos, econômicos, sociais e ambientais.

\section{ALGUMAS CONSIDERAÇÕES}

A construção de indicadores de interdisciplinaridade elaboradas a priori foi decisiva para nortear o desenvolvimento das atividades por parte dos palestrantes, bem como para verificar a presenças das características interdisciplinares durante 0 desenvolvimento das atividades do grupo.

A contribuição do grupo de estudos na formação inicial de professores refere-se ao

\section{REFERÊNCIAS}

[1] Lapa, M.J., M.J, Berejano, R.N, Penido, M.C.M. 2015. Interdisciplinaridade e o ensino de ciências: uma análise da produção recente. SABERES, Natal, v. 1, n. 11, fev. 2015.

[2] Pires, F.M.C Multidisciplinaridade, Interdisciplinaridade e Transdisciplinaridade no Ensino. Interface - Comunicação, Saúde, Educação - fev.1998

[3] Fourez, G. Fondements épistemologiques pour L'interdisciplinarité, In: LENOIR, Y.; REY, B.; Fazenda, I. Les fondements de $L$ 'interdisciplinarité dans la formation à L'enseignement. Canadá: Éditions du CRP/UNESCO, 2001.

[4] Fazenda, I. C.A. Interdisciplinaridade e Transdisciplinaridade na formação de Professores. Revista do Centro de Educação e Letras: v.8, n1, 93-103, 2008.

[5] Lenoir, Y.; REY, B.; Fazenda, I. Les fondements de L'interdisciplinarité dans la formation à L'enseignement. Canadá: Éditions du CRP/UNESCO, 2001.

INFANTE-MALACHIAS, M.E. Interdisciplinaridade e resolução de problemas: algumas questões para quem forma futuros professores de ciências. In: Santos, C.A. \& Quadros, A.F. Utopia em busca de possibilidade: abordagens interdisciplinares no ensino das ciências da natureza. Editora Unila, Foz do Iguaçu. 2011.

[6] Coimbra, S.A. Interdisciplinaridade e Educação ambiental: Integrando seus princípios necessários. Rev. eletrônica Mestr. Educ. Ambient. ISSN 1517-1256, Volume 14, janeiro a junho de 2005.

[7] Brasil/Mec - Ministério da Educação Resolução № 2, de 15 de junho de 2012 contato com temas ambientais por meio de estratégias didáticas instigadoras de processos de criticidade e reflexões, em especial para tomada de decisões como futuros educadores.

Até o momento, a pesquisa tem permitido ao grupo uma formação complementar ao ensino curricular dos licenciandos participantes e tem motivado para aprofundamentos tanto relacionados às práticas interdisciplinares quanto à Educação Ambiental.

Espera-se que a partir desta vivência no grupo os licenciandos tenham mais autonomia intelectual na busca pelo conhecimento, assumindo com protagonismo o fazer docente.

Para a área de Ensino de Ciências, o estudo fornece indicadores para construção de práticas interdisciplinares, contribuindo para o desenvolvimento de estratégias didáticas mais pertinentes à formação de professores no contexto atual.

(http://conferenciainfanto.mec.gov.br/images/pdf/di retrizes.pdf). Acessado 15/12/2016

[8] [9] Patton, M. Q. Qualitative research and evaluation methods. $3^{\text {a }}$ ed. Sage Publications, 2002.

[9] Bardin, L. Análise de conteúdo. Editora Presses Universitaires de France. 2011.

[10] Caniato, R. Interdisciplinaridade no ensino das ciências. In: Santos, C.A. \& Quadros, A.F. Utopia em busca de possibilidade: abordagens interdisciplinares no ensino das ciências da natureza. Editora Unila, Foz do Iguaçu. 2011.

[11] Santos, C.A. Energia e Matéria: conceitoschave para a interdisciplinaridade no ensino de ciências da natureza. In: Santos, C.A. \& Quadros, A.F. Utopia em busca de possibilidade: abordagens interdisciplinares no ensino das ciências da natureza. Foz do Iguaçu: Unila, 2011. [12] Jacobi, P.R., Guerra, A.F.S., Sulaiman, S.N. \& Nepomuceno, T. Mudanças climáticas globais: a resposta da educação. Revista brasileira de educação, v.16, n.46, 2011.

[13] Moreira, M.A. Metodologia de Pesquisa em Ensino. São Paulo: Livraria da Física, 2011.

[14] Pedrini, A.G. A educação ambiental com a biodiversidade no Brasil: um ensaio. Ambiente e educação, v.11, 63-77, 2006.

[15] Silva, P.S; MORTMER, E.F. O projeto temático na sala de aula: mudanças nas interações discursivas. VII ENPEC, 2009.

[16] Stumpf, B. O. Percepções de educadores sobre a permacultura como estratégia de educação ambiental escolar. IX ANPED Sul, 2012. [17] Silva, A. T. R. Pedagogia ambiental. Revista Eletrônica do Mestrado em Educação Ambiental, Rio Grande (RS), v. 25, p. 253-265, jul./dez. 2010. 


\section{Capítulo 4}

\section{PERCEPÇÃO DE ESTUDANTES SOBRE O AMBIENTE URBANO \\ José Daniel Soler Garves \\ Ângela Coletto Morales Escolano}

Resumo: Com o crescimento populacional e a melhoria da civilização, foi necessário aperfeiçoar e atuar coletivamente buscando saídas para dificuldades ambientais, sendo a Educação Ambiental uma das formas de modificar esse cenário. O objetivo deste trabalho foi diagnosticar conhecimentos dos alunos para elencar e problematizar conceitos que os conectem às diversas maneiras de expressão da natureza, investigando problemas e discutindo propostas para solucioná-los. Participaram do projeto cerca de 80 alunos do $6^{\circ}$ ano do Ensino Fundamental de uma escola Pública Estadual no município de Ilha Solteira (SP). As atividades foram realizadas em 2016 no período normal de aulas. A partir de expressões de confiança e esperança na proteção e manutenção do ambiente vivenciadas no projeto, conclui-se que é necessário acreditar e apostar nessa geração, não bastando apenas apontar atitudes de outras pessoas, mas fazendose necessário mudar suas próprias práticas rotineiras.

Palavras chave: educação ambiental urbana, problemas ambientais urbanos, sensibilização, sustentabilidade, ensino fundamental. 


\section{INTRODUÇÃO}

Ao longo de toda a história da humanidade houve sempre uma forte relação entre o homem e o ambiente, relação esta que se manteve em relativa harmonia até meados do século XIX, onde a partir da era industrial e com o surgimento de grandes aglomerações urbanas, esta harmonia foi desequilibrada, resultando em vários problemas ambientais que começaram a ser tratados com grande prioridade apenas recentemente.

A fim de evitar esses problemas, diversas resoluções e propostas foram criadas, conferências, encontros e reuniões entre diversos países. A conferência de Estocolmo em 1972, por exemplo, deu o pontapé inicial para as discussões sobre a preservação do meio ambiente e para o desenvolvimento sustentável das cidades.

Desta forma, com a melhoria da civilização foi imprescindível novas formas de se aperfeiçoar e atuar coletivamente em busca de saídas para as dificuldades da sociedade, sendo a Educação Ambiental (EA) uma das formas de modificar esse cenário, como destaca Czapski:

É um processo permanente. Trabalha com conhecimentos, atitudes e valores, e não apenas através da transmissão de informações. Envolve a participação individual em processos coletivos, trabalhando desde a perspectiva local até a global. Consegue mudar a visão da pessoa em relação ao local onde vive. Não deve se limitar a um ambiente fechado. Envolve a família e a coletividade. É obrigatória em todos os níveis de ensino, mas não é uma disciplina. Estimula o senso crítico e a compreensão da complexidade dos aspectos que envolvem a realidade em torno de si. Não tem uma proposta fechada de metodologia ou prática. E, na verdade, ainda está em implantação. (CZAPSKI, 1998, citado por SUDAN, 2007, p. 52).

Caminhando ao lado da EA, o desenvolvimento sustentável pode garantir a sobrevivência e permanência de vida na terra, para tanto é necessário articular novos rumos dessa educação para que de fato, haja um padrão de desenvolvimento por meio de critérios que promovam responsabilidade ética e definições de relações harmoniosas entre a sociedade e a natureza.

Sendo assim, é indispensável para o desenvolvimento do sujeito que o processo educativo deva se pautar também na EA, uma vez que a formação da consciência ecológica é de fundamental importância para a garantia de vida futura. Contudo, a EA é vista hoje como uma perspectiva de mudança ativa da realidade e das condições de vida, por intermédio da conscientização iniciada do processo social reflexivo em diversos aspectos educativos formais e não formais.

Para muitos especialistas, 1997 foi o ano da EA no Brasil. Segundo Melnnis (2009), dois fatos podem ajudar a entender a ascensão do tema que fez deste ano um marco para quem estuda a história da EA brasileira. Por um lado, a comemoração das duas décadas de realização da Conferência de Tbilisi, promovida pela UNESCO em 1977, na capital da Geórgia, ex-União Soviética, que resultou em um documento final que é a base para a visão moderna da EA. Por outro lado, era o momento de avaliar os cinco anos da Conferência das Nações Unidas sobre o Meio Ambiente e o Desenvolvimento, mais conhecida como Rio-92, onde finalizou-se a construção do Tratado de Educação Ambiental para as Sociedades Sustentáveis e Responsabilidade Global, referência para quem quer trabalhar EA em qualquer parte do mundo.

A escola possui papel fundamental na formação ética e na inclusão do cidadão na sociedade. Para Santos (2011), o ensino deve ser reconhecido como um processo no qual, os indivíduos possam desenvolver plenamente suas potencialidades e agregar conhecimentos que permitam sua efetiva participação nas decisões que afetem o desenvolvimento de sua comunidade e, consequentemente, de sua cidade, estado e país. Sendo assim, podemos discutir sobre a importância da escola na formação de um cidadão ecologicamente correto e adequado às necessidades atuais do meio ambiente.

Hoje, o tema meio ambiente é um dos temas transversais que requer uma postura afinada do corpo pedagógico da escola no sentido de desenvolver uma prática eficaz, envolvente e compromissada de todos. Para Barbosa (2011), dentre diversas ações e propostas políticas, a educação é uma das alternativas que pode contribuir para a sensibilização e transformação dos atores sociais, pois os educadores são formadores de opiniões e 
podem estimular o senso crítico dos alunos, produzindo alterações significativas em seus comportamentos, e levá-los a novos hábitos e atitudes em relação ao meio ambiente físico, social, cultural e econômico, pautados em valores que propiciem a relação de equilíbrio homem/natureza.

É notório que as cidades concentram a maior parcela da população brasileira e que o processo de urbanização tem-se estendido até áreas bastante circunscritas do território nacional. Os problemas de milhões de pessoas residentes nas cidades têm uma forte ligação com os problemas ambientais decorrentes dessas aglomerações. Entre eles, a carência de saneamento básico e de serviços públicos, a poluição em suas mais diversas formas, os conflitos de usos do solo, a localização inadequada de atividades e os graves contrastes sociais, são fatores que fazem da gestão urbana um problema altamente complexo, não permitindo respostas clássicas ou simplesmente técnicas, exige-se uma resposta política e devidamente negociada entre os diversos atores urbanos (RIBEIRO; VARGAS, 2001).

Apesar das cidades terem se tornado um ambiente onde a vida do ser humano se tornou possível, elas nunca perderão a ligação com o ambiente natural, pois é desse ambiente que todas as cidades retiram muitos recursos necessários para sua existência e completo funcionamento.

\section{OBJETIVOS}

Diagnosticar os conhecimentos prévios dos alunos do $6^{\circ}$ ano do Ensino Fundamental em relação à Educação Ambiental Urbana (EAU) para posteriormente elencar, problematizar e relacionar conceitos que conectem os alunos às diversas maneiras de expressão da natureza no ambiente em que vivemos, além de investigar especificamente o que os alunos identificam como problema ambiental no ambiente em seu entorno (residência, escola, bairro, município) e quais as possíveis propostas para solucionar tais problemas.

\section{METODOLOGIA}

Foram participantes do presente projeto cerca de 80 alunos do $6^{\circ}$ ano do Ensino Fundamental de uma escola pública estadual no município de llha Solteira (SP). As atividades foram realizadas ao longo do ano de 2016 durante o período normal de aulas (matutino e vespertino) no Laboratório de Ciências da escola, utilizando-se horários de aulas de diversas disciplinas (Ciências, Geografia, História, Matemática e Português).

Para sua realização, o trabalho foi dividido em três etapas descritas a seguir:

\section{1ㄹ ETAPA: APLICAÇÃO DE CONCEITOS SOBRE EDUCAÇÃO AMBIENTAL URBANA:}

Foram realizados quatro encontros onde, de forma expositiva/participativa, com auxílio de recursos áudio visuais, foram tratados os seguintes temas:

ENCONTRO I: Conceitos sobre meio ambiente com enfoque ao meio ambiente urbano.

O que significa meio ambiente?

Fatores que influenciam o meio ambiente;

Histórico das relações do ser humano com o meio ambiente;

Tipos de meio ambiente;

Cidades jardins.

ENCONTRO II: Problemas ambientais urbanos.

Poluição do solo;

Poluição da água;

Poluição do ar;

Poluição visual;

Poluição sonora;

Enchentes;

Falta de áreas verdes.

Neste encontro, os alunos foram orientados a observar e registrar por meio de fotografias, desenhos, textos ou mensagens, problemas de poluição ambiental encontrados durante o percurso que fazem da casa até a escola.

ENCONTRO III: Problemas ambientais urbanos com enfoque ao lixo.

Possíveis destinos do lixo (lixão, aterro sanitário, compostagem ou incineração);

Classificação do lixo: propriedades materiais e seu local de origem;

Consequências dos problemas do lixo nas cidades;

Tempo de degradação do lixo no meio 
ambiente.

\section{ENCONTRO IV: Sustentabilidade das} cidades.

O que é sustentabilidade?

Por que termos uma cidade sustentável?

Ações sustentáveis.

\section{2 ${ }^{2}$ ETAPA: IDENTIFICAÇÃO DE PROBLEMAS AMBIENTAIS URBANOS,}

Nesta etapa, os alunos desenvolveram atividades em dois encontros, buscando identificar problemas ambientais urbanos e como estes influenciam no equilíbrio homem/natureza.

ATIVIDADE I: Dinâmica "O destino que você dá...". Nessa dinâmica os alunos descreveram como é a escola onde estudam e como é a cidade onde moram, citando mudanças que podem ser feitas para melhorar a qualidade destes dois ambientes. Eles trocaram informações entre si para o enriquecimento de dados e fizeram anotações sobre o desenvolvimento da atividade, que contou com a confecção de cartazes que classificavam os tipos de lixos existentes no meio urbano por meio de recortes de imagens de revistas, com as seguintes classes: "reciclar ou reutilizar" - (latas de alumínio, garrafas pet); "incinerar" - (produtos químicos); "compostagem" - (lixo orgânico); "tratamentos especiais" - (lixos hospitalares); "aterro sanitário" - (lixo doméstico); e um último "O meio ambiente e os animais agradecem" - (organismos em harmonia com a natureza).

ATIVIDADE II: Registrando problemas ambientais urbanos.

$\mathrm{Na}$ atividade "Como é o ambiente em que você vive e o que ele precisa para melhorar" os alunos realizaram registros sobre os problemas ambientais encontrados na cidade por meio de relatos, desenhos ou fotos, que foram capturadas por câmeras fotográficas ou celulares. Esta observação ocorreu ao longo de todo o projeto em trajetos como a casa dos alunos até a escola, ou de casa ao supermercado, etc.

\section{3를 ETAPA: BUSCA DE SOLUÇÕES.}

Nesta etapa, os alunos escolheram (individualmente, em duplas ou trios) um problema ambiental urbano que consideraram de maior relevância, e redigiram uma carta para amigos, familiares ou desconhecidos que tenham realizado atitudes que interferem de maneira negativa na conservação do meio ambiente, justificando o motivo desta escolha e uma possível solução para este problema.

\section{RESULTADOS E DISCUSSÕES}

Considerando termos ambientais, em 1981, a Política Nacional do Meio Ambiente reconhece e julga importante incluir a EA em seus princípios, reconhecendo seu papel fundamental dentro de todos os níveis de educação, salientando ainda a participação da comunidade com cidadãos ambientais ativos, bem como a conscientização pública dentro das cidades, definindo a EA como uma dimensão da educação, sendo uma grande aliada na busca por soluções ambientais. (FARIAS; FREITAS, 2007; REIGADA; REIS, 2004).

Seguindo na mesma linha e com significativa expressão a EA ganhou mais importância em 1992, com o Tratado de Educação Ambiental para Sociedade Sustentáveis e Responsabilidade Global, que além de seus princípios ambientais retrata o papel que a educação deve propor na formação de valores e transformação de sociedades. (FARIAS; FREITAS, 2007).

Desta forma, as aulas teóricas iniciais serviram como base para o desenvolvimento de todo o projeto, englobando conceitos e exemplos globais e do cotidiano dos alunos. Ao longo das aulas houve muitos questionamentos em relação aos problemas ambientais e os tipos de poluição existentes, o que de certa forma, comprova a falta de contato com a temática e a carência de informações sobre o assunto, especificamente com a Educação Ambiental Urbana, como retrata Macedo e Ramos (2015) em seu trabalho sobre a relação da EA com resíduos sólidos urbanos:

Embora já muito trabalho se encontre feito no sentido de estudar a aplicação dos projetos de educação ambiental e conhecer de que forma esta educação contribui para um desenvolvimento sustentável, os estudos mostram que a educação ambiental ainda é insuficiente. (MACEDO; RAMOS, 2015).

Ações sustentáveis como economizar água e 
não desperdiçar energia, e a possibilidade de contribuir com o meio ambiente separando os tipos de lixos também foram pontos nos quais os alunos mais se identificaram, sugerindo ideias e opinando sobre familiares, amigos e até desconhecidos que apresentaram atitudes não muito corretas perante 0 ambiente.

No segundo encontro do projeto foi possível perceber que a atividade de recortes de revistas para confecção de cartazes motivou os alunos a refletirem sobre o meio ambiente e como a cidade, a escola e a interferência antrópica em si interferem na degradação e complexidade ambiental. No momento da dinâmica os alunos foram incentivados a tentar classificar os tipos de lixos nas categorias existentes para tal, estimulando o trabalho em equipe, pois eram necessários palpites, bem como a busca por soluções dos problemas ambientais que temos contato diariamente.

Figura 1: recortes de revistas e confecção de cartazes.

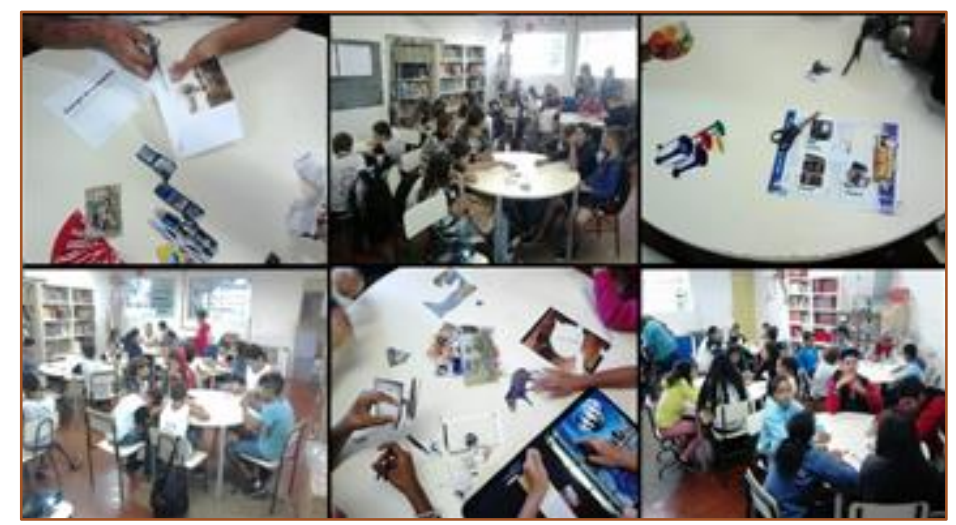

Figura 2: cartazes prontos divididos em categorias.

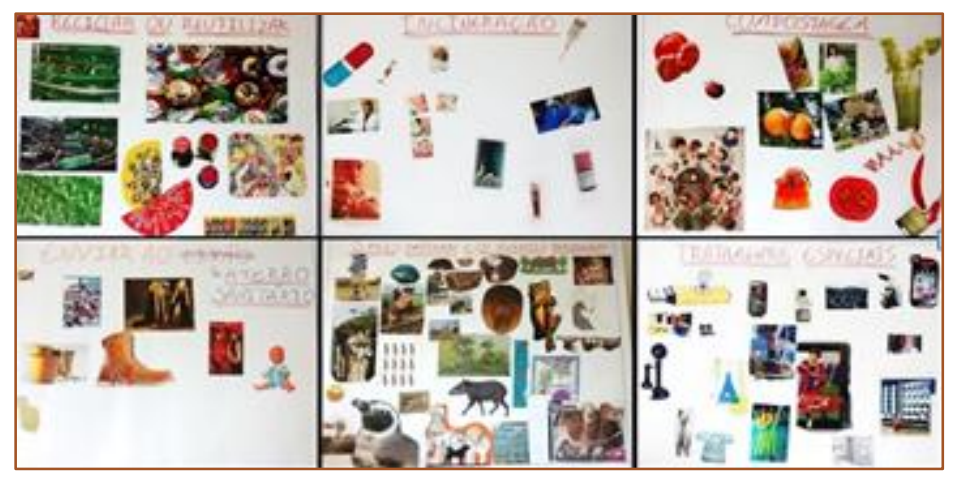

Como foi nítido no presente trabalho, para aplicar conceitos de EA no ambiente urbano, devemos tomar como base a tão problemática e evidente produção demasiada e o descarte incorreto de lixo, como ressalta CARVALHO et al., (2009):

O século em que vivemos está caracterizado pela redução do ciclo de vida dos bens e obsolescência precoce, causada pela febre do lançamento de novos produtos que contribuem sensivelmente para o aumento dos rejeitos gerados pela sociedade. Conviver com o desenvolvimento das atividades humanas, o crescimento das cidades e o aumento do consumo de recursos naturais nãorenováveis, serão sem sombra de dúvida um dos maiores desafios para humanidade no século XXI (CARVALHO et al., 2009, p. 3).

Atualmente, o desafio que o lixo representa para as grandes cidades além de ser ambiental é também social, e sua magnitude deve ser levada em consideração. (SANTOS et al., 2015). Desta forma, é necessário que os alunos sintam que a cidade em que vivem também faz parte do ambiente, assim, a EA adentra no contexto urbano e introduz 
conceitos ambientais relacionados aos municípios e grandes centros urbanos de acordo com o desenvolvimento industrial e tecnológico das cidades, em parceria com os princípios da sustentabilidade.

A fim de despertar o poder de observação e o senso crítico dos alunos na detecção de problemas, a atividade de "Como é o ambiente em que você vive e o que ele precisa para melhorar." apresentou resultados espantosos. A quantidade de lixo encontrado na cidade de Ilha Solteira foi imensa, em vários bairros da cidade os alunos registraram cenas que os decepcionaram.

Apesar do desapontamento com a população, a atividade serviu como parâmetro para a idealização das cartas a serem direcionadas para as pessoas ou órgãos responsáveis por tais poluições ou pelo recolhimento dos entulhos, e ainda para ressaltar a importância de conservar as chamadas "áreas verdes", já que a maioria dos resíduos encontrados se localizavam em áreas abertas e com vegetação.

Figura 3: registro de lixos espalhados pela cidade de Ilha Solteira.

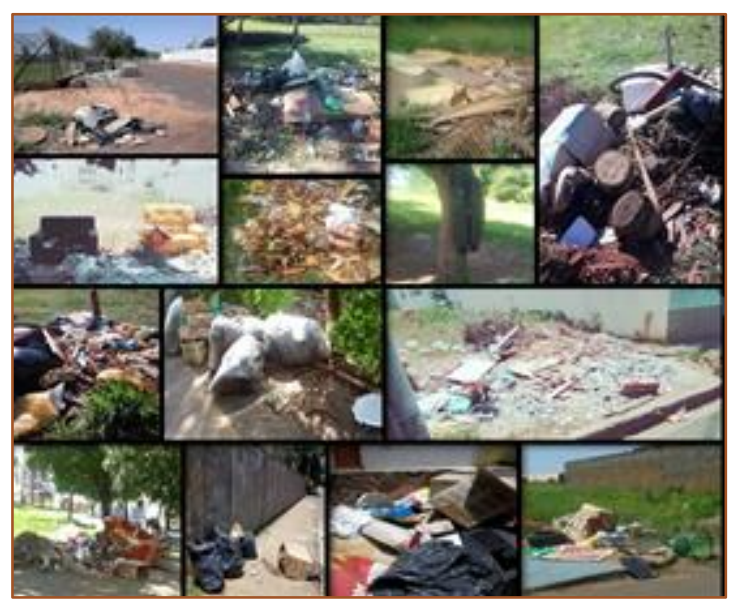

Tais atividades trazem consigo uma gama de informações no qual os indivíduos são convidados a compreender e agir de forma autônoma sobre situações da comunidade, ou seja, conhecer a realidade para preservá-la, já que este é um dos princípios da EA e incentiva cidadãos a serem mais críticos e também que (re)pensem suas atitudes socioambientais. (JANKE; REIS, 2008).

De acordo com a formação dos grupos e as identificações dos problemas presentes no dia-a-dia, os alunos elaboraram cartas onde levantaram os problemas ambientais. Estas foram analisadas utilizando a metodologia de análise de conteúdo de Bardin (1977). A seguir serão apresentadas as categorias e subcategorias com seus principais exemplos:

\section{EXCESSO DE LIXO:}

\section{$1 \mathrm{a}$ - Problemas ambientais e sociais:}

"Gostaria que você parasse de jogar lixo na rua porque fica sujo e prejudica outras pessoas, com doenças. Então use o óleo para fazer sabão e amarre o lixo no portão para o vento não derrubar."

"...quero te dizer para refletir e ver os prejuizos causados pelo lixo como enchente, mal cheiro e etc."

"...lembre que o seu lixo não fala mas diz muito sobre você!"

"Os moradores tacam muitos lixos em área verde, ao invés de progredirem em fazerem plantações lá."

"Meu vizinho joga lixo perto de um rio, fico indignado porque esse lixo vai pro rio e o chorume do lixo contamina o solo e o lençol freático."

"...quinta feira retra tinha tanto lixo que alagou a cidade inteira. Casas desmoronarão depois disso varias pessouas ficaram doente com Dengue, Zika, Chicogunha 3 pessoas morreram."

\section{1 b - Incineração:}

"Vizinha, pare de tacar lixo perto de sua casa e botango fogo porque isso pode trazer poluição do ar e quem tem problemas 
respiratórios e para os animais que pode comer o lixo e podem acabando transmitindo doenças que podem levar até a morte."

$1 c$ - Reciclagem e reutilização:

"Acho que todos nós merecemos respeito e o meio ambiente também cuide, recicle, e crie porque o lixo vira arte na mão de quem tem talento."

"...separasse os lixos nos devidos lugares como lixo orgânico separe de vidro quebrado e outros."

“...você pode separar lixo orgânico de reciclável, e ensinar as outras pessoas a fazerem o mesmo."

1d - Destino incorreto:

"...o lixo que vocês jogam na escola demora pra decompor, como papel de bala, de biscoito etc."

"Não é só os catador de lixo que tem que faser o seu trabalho vc também tenque fazer."

"...uma pergunta para onde vai o nosso lixo? Para o aterro sanitário ou para lugares inadequados?"

"...pegasse e separasse o lixo porque vimos que está tudo junto, cada lixo tem um tipo, vidro, plástico, metal e papel."

"...restos de lixo como: palito de pirulito, papel de bala etc...então para que o lixo não seja jogado incorretamente, fique atento a sua atitude."

\section{POLUIÇÃO E DEGRADAÇÃO:}

$2 a$ - Poluição atmosférica:

"lixos jogados por vários lugares, carros soltando fumasa para todos os lados. Pedimos apoio da Prefeitura para que ela manda caminhões para recolher os lixos da cidade, e os carros possa serem arrumados ou mutado por poluição do ar."

2b - Poluição edáfica (solo):

"Vi uma pessoa desmatando arvores que estavam do lado do rio isso causa problemas ambientais e tira nutrientes do solo."

\section{2c - Poluição sonora:}

"Um vizinho meu escuta som muito alto e com palavrões atrapalhando pessoas a durmir e incentivando as crianças a falar tais palavras."

2d - Desmatamento:
"Meu amigo costuma falar que geralmente ele desmatou muitas arvorès, e eu acho que isso é muito errado por que as arvorès são nosso oxigênio para nós respirar... se esse lixo ficar por muito tempo vai prejudicar o solo ... ou se chuver vai virar chorume e vai para o rio."

"O meu primo K. cortou a arvore e fiquei muito triste porque eu gostava dela porque fazia uma sombra muito boa ..."

"Vi uma pessoa desmatando arvores que estavam do lado do rio isso causa muitos problemas ambientais e tira nutrientes do solo."

\section{DESPERDÍCIO:}

3a - Dicas para economia e reutilização de água:

"O senhor está lavando o quintal todos os dias com a mangueira e isto não é necessário ... O nosso conselho é que não desperdisse água, não jogue folhas nos bueiros."

"Não gastar muita gua quando lavar a área ou o quintal, quando for lavar o carro não utilizar muita água somente um balde com sabão ..."

“... Quando for lavar louca usa pouca agua; Quando for escovar os dentes liga e condo for preziso liga; Quando for lavar a calçada varre ou com um balde; O carro lave com um balde não precisa de mangueira; Agua de maquina joga nas plantas ou na calçada;"

\section{3b - Dicas para economia de energia elétrica:}

"Mãe, quando você estiver no quarto e quiser ir para a sala desliga a luz e não deixe assesa igal a tv e o carregado na tomada toda horas que gasta energia para o dia a dia nosso."

\section{SENSIBILIZAÇÃO:}

\section{4a - Criação de projetos:}

“...não jogue mais lixo, ande menos de carro e mais de bicicleta. Junto podemos ajudar o meio ambiente, pensamos em organizar um grupo para realizar uma convenção."

"Poderíamos fazer uma campanha \#poluição não!"

"Gostariamos que vocês elaborassem um projeto para limpar os rios e córregos de nosso Estado, precisamos disso pois a água é a vida ... futuramente seus filhos e netos passaram por necesssidades." 
"Presidente Temer, nós gostaríamos que você criasseum projeto para plantar mais árvores em São Paulo e em outras cidades para a vida na terra melhorar e também gostaríamos de uma lei que uma cidade pequena tenha no mínimo 1000 arvores e uma cidade grande ou mediano 16000 arvores, uma ideia de como fazer isso é o famoso této verde!"

"Diretora, todos os alunos estão percebendo que nossa escola está precisando passar por um momento de consciência ambiental ... Os alunos também estão precisando colaborar com a escola. Estamos precisando de mais lixeiras de reciclagem, nos corredores salas etc.

"Michel temer gostaríamos que você inplantace um projeto quanto a pequenas áreas verdes dentro das cidades para minimizar o impacto da poluição do ar ... e aumentar a observação demtro de propriedades como fazendas, para evitar queimadas de cana e mata ativa."

\section{4b - Consciência individual:}

"Mãe, eu aprendi coisas do meio ambiente tipo a poluição do ar quando uma cidade tem muita fumaça de alsina seramica ou carros cria uma nuvem de fumaça que faz a chuva toxica também tem o efeito estufa quando os raios de sol bate na terra ele volta mas por causa da fumasa da cidade os raios de sol vai e volta e vai ficando mais quentes."

4c - Descaso:

"...a pessoa estava jogando seu proprio lixo na rua. Tem tei fazelo para com essa atitude mais ele não mideu ouvidos ... esperei um tempó por cerca de 2 meses fui verificar como ele estava indo eu me assustei, por que vi ele sendo levado numa maca ... o infermeiro afirmou que ele tinha sido picado por um escorpião e que o lixo dele era o culpado sem remórcio algum eu ri muito e disse - Eu avisei."

"Um dia no caminho de casa até a escola vi coisas quebradas e rasgadas: sofá velho, pedaços de TV antiga, micro-ondas, latas de refrigerante, garrafas pet, bituca de cigarro. Mais a frente havia uma placa dizendo NÃO JOGUE LIXO AQUI."

Para considerar tais exemplos como soluções para os problemas ambientais identificados é de extrema necessidade analisa-los de acordo com o pensamento crítico dos alunos e ressaltar a importância de cada cidadão dentro da sociedade e como será o futuro dos próprios alunos, incentivando-os a criar ideias inovadoras e atitudes que contribuam para um ambiente melhor.

\section{CONSIDERAÇÕES FINAIS}

A partir das diversas expressões de confiança e esperança na proteção e manutenção do ambiente vivenciadas ao longo do projeto, conclui-se que é necessário acreditar e apostar nessa geração. Esses jovens alunos não são como grande parte da população que já estão com conceitos formados e totalmente influenciados pelo sistema global atual, eles ainda estão em formação, e cabe a nós sensibilizá-los a se envolver com consciência e respeito às leis naturais, possibilitando-os o contato direto com o caos atual, entretanto, estimulando-os a valorizar e criar atos "ambientalmente corretos".

Alguns relatos reconhecem a importância de cada indivíduo olhar para si mesmo e aceitar que suas atitudes também contribuem para os problemas ambientais encontrados na cidade, ou seja, não basta apenas olhar e apontar atitudes de outras pessoas, bem como faz-se necessário mudar suas próprias práticas rotineiras.

Devemos também salientar a importância do "Conhecer para preservar", onde a identificação de problemas ambientais ao nosso redor favorece a prática da conservação. Como o sistema atual nos limita de tal forma que dificuldades para combater o modelo padrão de vida atual são notáveis, consumismo e utilitarismo devem ceder lugar a sustentabilidade, e a preocupação atual deve ser com os recursos que estão se esgotando a cada dia.

A temática ambiental por ainda ser um assunto novo enfrenta dificuldades e certa resistência de grandes centros econômicos como empresas, indústrias e é claro, uma boa parte da população mundial. O ciclo vicioso que engloba primordialmente 0 setor econômico destrói qualquer tipo de ação de conservação, por isso devemos resistir e trabalhar cada vez mais com as crianças, que poderão fazer do futuro um meio mais equilibrado e menos resistente aos princípios ambientais.

Trabalhos continuados de educação ambiental podem colaborar para o enfrentamento das questões ambientais atuais, transformar relações sociais e ainda 
estimular cuidados voltados à sustentabilidade socioambiental como parte da cultura das distintas sociedades humanas, e especialmente de cada indivíduo, ou seja, devemos tentar estimular e contribuir para a formação de sujeitos ativos e que se importam em transformar a sua realidade para melhor.

\section{REFERÊNCIAS}

[1]Barbosa E. P. S. Representatividade da Educação Ambiental no Espaço Escolar. 2011. Disponível em: $<$ http://www.revistaea.org/artigo.php?idartigo=966 \&class=02>. Acesso em: 20 dez. 2016.

[2]Bardin, L. Análise de conteúdo. Lisboa: Edições 70, 1977

[3]Carvalho, K. M. de; HIDD, R. L. C.; SILVEIRA, D. M. R. L. Responsabilidade sócio-ambiental na gestão pública. In: Congresso do Conselho Nacional de Secretários do Estado da Administração de Gestão Pública (CONSAD), 2009, Brasília. (Anais). Disponível em: <http://www.escoladegestao.pr.gov.br/arquivos/File /Material_\%20CONSAD/paineis_II_congresso_cons ad/painel_56/responsabilidade_socio_ambiental_n a_gestao_publica.pdf >. Acesso em: 21 dez. 2016.

[4]Farias, C. R. O.; FREITAS, D. Educação Ambiental e Relações CTS: Uma Perspectiva Integradora. Ciência \& Ensino, Campinas, v. 1, n. especial, nov. 2007.

[5]Janke, N.; REIS, M. F. C. T. Produção Coletiva de Conhecimentos Sobre Qualidade de Vida: Por uma Educação Ambiental Participativa e Emancipatória. Ciência \& Educação, v. 14, n. 1, p. 147-157, 2008

[6]Kondrat, H.; MACIEL, M. D. Educação Ambiental para a Escola Básica: Contribuições para o Desenvolvimento da Cidadania e da Sustentabilidade. Revista Brasileira de Educação, São Paulo, v. 18, n. 55, p.825-846, Out/Dez 2013.

[7]Macedo, M. A. A. P. T.; RAMOS, M. C. P. Educação Ambiental e Resíduos Sólidos Urbanos: Caminho para um Futuro Sustentável. Eduser:

[15] Recicla / Agência USP de Inovação, 2007. $245 p$

\section{AGRADECIMENTOS E APOIOS}

Trabalho realizado com 0 apoio da PROGRAD-UNESP/Programa Núcleos de Ensino. Agradecimentos a escola parceira e ao PIBID/Capes/UNESP.

Revista de Educação, Bragança, v. 7(2), p.41-57, 2015

[8]Melnnis N. A raiz do dilema ambiental está na forma como aprendemos a pensar o mundo: dividindo-o em pedaços. In. CZAPSKI S.. Os diferentes matizes da educação ambiental no Brasil. 2009, Brasília: 1997-2007. P. 27-31.

[9]Ministério Do Meio Ambiente. Tratado de Educação Ambiental para Sociedades Sustentáveis e Responsabilidade Global. 1992. Disponível em: $<$ http://www.mma.gov.br/port/sdi/ea/deds/pdfs/trat_ ea.pdf>. Acesso em: 20 dez. 2016.

[10] Reigada, C.; Reis, M. F. C. T. Educação Ambiental para Crianças no Ambiente Urbano: Uma Proposta de Pesquisa-Ação. Ciência \& Educação, v. 10, n. 2, p. 149-159, 2004.

[11] Ribeiro H.; Vargas. Novos instrumentos de gestão ambiental urbana. São Paulo, Edusp, 2001.

[12] Santos, A. Educação ambiental: um desafio na formação de novos cidadãos. Universidade de Brasília, 2011. Disponível em: <http://bdm.unb.br/bitstream/10483/1905/1/TCC_L uziania_Adilson\%20dos\%20Santos.pdf> Acesso em: 20 dez. 2016.

[13] Santos, M. T. et al. Olhar fotográfico sobre o lixo. In: X Encontro Nacional de Pesquisa em Educação em Ciências - X ENPEC, 2015, (Anais) Águas de Lindóia: p. 1 - 8. Disponível em: <http://www.xenpec.com.br/anais2015/resumos/R1 302-1.PDF>. Acesso em: 19 dez. 2016.

[14] Sudan et al. Da Pá Virada: Revirando o Tema Lixo. Vivências em Educação Ambiental e Resíduos Sólidos. São Paulo: Programa USP 


\section{Bapítulo 5}

\section{APRENDENDO \\ CIÊNCIAS E \\ DESENVOLVENDO CRITICIDADE NOS AMBIENTES COSTEIROS CAPIXABAS}

\section{Guilherme Augusto Maciel Ribeiro}

Brenda Odete Pfeiffer de Araújo

Luciane da Silva Lima Vieira

Maria Margareth Cancian Roldi

Carlos Roberto Pires Campos

Resumo Desenvolveu-se um estudo interdisciplinar a partir de uma aula de campo em ambiente costeiro no litoral sul capixaba mediado por uma sequência didática fundamentada nos Três Momentos Pedagógicos de Delizoicov et al. (2002) e nas contribuições da Alfabetização Científica. Esta ação objetivou identificar os indicadores de Alfabetização Científica relacionados à construção dos conhecimentos dos alunos da educação básica acerca de processos de formação do solo e de modelação do relevo face às questões socioambientais. O trabalho permitiu a construção de complexas relações entre os conhecimentos sistematizados e apreendidos na escola confrontados com aqueles com os quais os alunos se defrontam no dia-a-dia, evidenciando-se os princípios da Alfabetização Científica. Acredita-se que o estudo apresentado oportunizou o exercício de uma educação integralizadora e crítica ao mobilizar os saberes escolares e as vivências dos alunos frente às atividades educativas socioambientais e científicas praticadas durante a aula de campo.

Palavras chave: Aula de campo; ensino de Ciências; ambiente costeiro; alfabetização científica; espaços não formais. 


\section{INTRODUÇÃO}

O litoral do município de Marataízes, no sul do estado do Espírito Santo, é composto por uma formação geológica conhecida por Formação Barreiras, uma estrutura de origem sedimentar continental e marinha, de idade miocênica à pleistocênica inferior (NUNES; SILVA, 2011). Apresentando uma variedade de estratificações em perfil de suas camadas estratigráficas devido a diferentes composições mineralógicas, a Formação Barreiras em Marataízes sofre ação direta de elementos erosivos, seja de modo natural (vento, chuva ou erosão marítima) ou antrópica (atividades agrícolas, construções civis e rodoviárias, atividades esportivas e turismo), o que constitui um ambiente favorável para estudos sobre sua formação, composição, perfil e debates socioambientais.

Considerado um Patrimônio Geológico Municipal de Marataízes, a Praia das Falésias oferece elementos viáveis para realização de uma aula de campo com o objetivo de estudar a dinâmica, a composição e o perfil de suas camadas, bem como para investigar os aspectos relativos à biodiversidade litorânea. Além disso, é possível explorar os estudos sobre as formas de utilização do solo em termos de atividades agrícolas ou turísticas e as respostas que a terra dá a estas atividades favorecendo, por meio dos debates, a interação dos estudantes com o espaço.

$\mathrm{Na}$ disciplina de Ciências existem vários conteúdos que podem ser trabalhados fora do espaço escolar. Estudar o solo apenas teoricamente pode ser distante e abstrato para os alunos. Uma maneira de tornar este conteúdo mais interessante se dá por meio da aula de campo em uma região de falésias. Esta reflexão coaduna com Seniciato e Cavassan (2004) quando afirmam que as aulas de Ciências e Biologia em ambientes naturais podem atingir os efeitos esperados de acordo com a metodologia de visita ao ambiente empregada, pois ajudam na motivação dos estudantes das diversas faixas etárias na busca pelo conhecimento.

O estudo do solo dos ambientes costais, a partir da compreensão do que representam as falésias, tanto para a geologia da região quanto para a história do Brasil, dialoga com as premissas da Alfabetização Científica (CHASSOT, 2003), dado que privilegia ações educativas que permitem compreender conhecimentos, procedimentos e valores em diferentes situações de aprendizagem. Estudos dos ambientes litorâneos capixabas tornam os alunos capazes de tomar decisões e perceber as muitas utilidades da ciência e suas aplicações na melhoria da qualidade de vida e suas limitações e consequências negativas para o cotidiano da vida em sociedade, especilmente porque na região existem dois grandes portos a serem implantados que impactarão sobremaneira os ecossistemas e as vidas que deles dependem. Chassot (2003) aponta a Alfabetização Científica (AC) na perspectiva de formação de cidadãs e cidadãos críticos que consigam entender as necessidades de transformar para melhor o mundo em que vivem, e ainda defende a exigência de uma ciência para a melhoria da vida no planeta.

A construção de atores escolares críticos dialoga com o que defendem Sasseron e Carvalho (2008), quando tratam da Alfabetização Científica, que parte do pressuposto de um ensino que possibilite

[...] aos alunos interagir com uma nova cultura, com uma nova forma de ver o mundo e seus acontecimentos, podendo modificá-los e a si próprio através da prática consciente propiciada por sua interação cerceada de saberes de noções e conhecimentos científicos, bem como das habilidades associadas ao fazer científico (p. 61).

Sasseron e Carvalho (2008), a partir de uma revisão bibliográfica sobre Alfabetização Científica, discutiram uma série de habilidades que diferentes autores listam como necessárias entre os alfabetizados cientificamente. Essas habilidades, destacadas pelos autores, permitem 0 entendimento de como o ensino deve se estruturar quando tem por objetivo proporcionar a Alfabetização Científica (AC) entre os alunos do Ensino Fundamental. A partir daí, as autoras agrupam essas habilidades em três eixos estruturantes, os quais buscam "[...] fornecer bases suficientes e necessárias de serem consideradas no momento da elaboração e planejamento de aulas e propostas de aulas que visando à Alfabetização Científica" (SASSERON; CARVALHO 2008, p. 75).

O primeiro eixo estruturante da AC diz respeito à compreensão básica dos termos, 
conhecimentos e conceitos científicos fundamentais, de forma que os alunos consigam aplicá-los em situações do seu cotidiano. O segundo eixo estruturante voltase para a compressão da natureza das ciências e dos fatores éticos e políticos que envolvem sua prática, referindo-se a uma ciência em constante mudança por meio de novas análises e síntese dos resultados que originaram os saberes. O terceiro eixo estruturante refere-se ao entendimento das relações existentes entre ciência, tecnologia, sociedade e meio-ambiente. Este último eixo deve ser trabalhado pela escola que almeja um futuro sustentável para a sociedade e o planeta (SASSERON; CARVALHO, 2008).

Pensando no alcance da $A C$ e postulando ser possível relacionar os conteúdos estudados durante a práxis educativa com os ambientes costeiros, justifica-se a propositura de diferentes metodologias educativas para 0 ensino do conteúdo "Solos", estudado no 6음 Ano do Ensino Fundamental. A partir de situações de aprendizagens diversas, proporcionadas pela exploração dos ambientes naturais pertencentes ao município em que vivem os estudantes, como as falésias, esperamos alcançar não apenas a alfabetização científica, mas a formação de novos conhecimentos, significados e posturas, dado o potencial pedagógico desse ambiente para o estudo científico de solos em outros contextos socioambientais.

Assim, levar os alunos a conhecer, descrever, identificar e refletir sobre o ambiente costeiro viabiliza um estudo transversal do conteúdo "Solo", vez que correlaciona os conceitos desenvolvidos em sala de aula a novos contextos de aprendizagem, sobretudo àqueles associados ao uso socioambiental do território. Portanto, têm-se as falésias como tema gerador para a transversalização de novos conhecimentos e significados em Ciências.

Nesse contexto, esse artigo tem por objetivo analisar uma aula de campo desenvolvida nos ambientes costeiros do litoral sul capixaba, a qual compunha uma sequência didática interdisciplinar intitulada "Solos e os ambientes Falésias", na busca de indicadores de Alfabetização Científica, bem como verificar como os alunos das séries finais do Ensino Fundamental articulam os conhecimentos sobre os processos de formação do solo e da modelação do relevo às questões socioambientais.

\section{METODOLOGIA E CONTEXTO DA INVESTIGAÇÃO}

Para a consecução dos objetivos propostos, optamos pela elaboração de uma sequência didática (SD) construída com base nos Três Momentos Pedagógicos de Delizoicov et al. (2002), envolvendo um total de 06 (seis) aulas da disciplina de Ciências e 04 (quatro) aulas da disciplina de Geografia, todas desenvolvidas no mês de outubro de 2016. Como sujeitos da pesquisa, participaram 26 (vinte e seis) alunos do 6o Ano do Ensino Fundamental, turno vespertino, da EMEIEF "Boa Vista do Sul", todos residentes na localidade rural de Boa Vista do Sul, litoral sul capixaba, usuários frequentes dos ambientes costais de falésias.

O planejamento da SD teve como contextualização o tema sociocientífico "Solos e o Ambiente Falésias", com foco na composição do solo, na biodiversidade litorânea e na sua utilização antrópica. A SD foi iniciada com uma problematização com o objetivo de investigar informações sobre a formação, composição e a utilização do solo costeiro de Marataízes, por meio da realização de uma pesquisa individual e coletiva sobre os principais produtos cultivados no solo marataizense na região de falésias, buscando informações sobre as formas de utilização do solo na região.

A segunda etapa da SD, que constituía na organização do conhecimento, objetivou demonstrar a composição e a mineralogia do solo em Marataízes (Formação Barreiras), descrevendo os principais processos de formação do solo, reconhecendo os principais elementos orgânicos e inorgânicos presentes na composição do solo, identificando os três principais tipos de solo (arenoso, argiloso e humoso) e observando as propriedades do solo (permeabilidade e porosidade). Essa etapa foi realizada por intermédio de aulas expositivo-participativas, com apoio de recurso audiovisual e do livro didático, registro de esquemas conceituais na lousa, data-show para estudo de imagens e construção de experimentos para observação de três amostras de solo, destacando os tipos de solo e seus elementos orgânicos e inorgânicos. Durante essa etapa foram trabalhados os principais conceitos sobre a formação do solo, com destaque para o solo de Marataízes.

$\mathrm{Na}$ terceira etapa, quando da aplicação dos conhecimentos, foram trabalhados os 
conteúdos que versavam sobre a Formação Barreiras (falésias) no território de Marataízes e a biodiversidade no sistema barreiras. Utilizou-se, como estratégia de ensinoaprendizagem, a aula de campo nas falésias da Formação Barreiras, quando foi realizado o registro em diário de bordo das ações educativas desenvolvidas a partir $\mathrm{da}$ observação das culturas agrícolas de Marataízes, da observação das falésias, do estudo da composição do solo e da vegetação no ambiente de falésias. Essa etapa objetivou levar os alunos a vivenciarem novo contato com as falésias da Formação Barreiras e, neste compasso, à reflexão sobre as principais ações antrópicas que este sistema tem sofrido desde o descobrimento.

Nessa etapa final, a compreensão sobre o ecossistema costeiro e suas feições geomorfológicas ocorreu a partir da observação de duas tipologias de falésias: uma considerada como falésia viva, onde a erosão marinha é evidente $e$, portanto, modeladora da área de barreira natural entre o continente e o mar, e outra, considerada falésia morta, onde não há mais erosão marinha, o que constitui um ambiente favorável para o desenvolvimento de espécies vegetais características de restinga, além de pequenos animais invertebrados e vertebrados. Diante de tal ambiente, procedeu-se ao estudo da biodiversidade que compõe o ambiente de falésias. Para tanto, foi feito um delineamento de área de estudos em quadrantes de $3 \mathrm{~m} \times 3 \mathrm{~m}$, utilizando-se palitos de madeira e barbantes. Os alunos foram motivados a registrar os elementos vivos e não vivos que poderiam ser observados em seus quadrantes. A atividade foi avaliada por meio da participação individual e coletiva, da capacidade de solucionar as atividades propostas em cada etapa de estudo e da capacidade de registro e de interpretação de dados durante a aula de campo. Um relatório final foi pedido para que as informações fossem sistematizadas e entregues ao professor.

Como forma de registro das evidências de aprendizagem pelos alunos, durante os momentos pedagógicos descritos, foram coletados dados a partir dos registros discentes por meio de diário de bordo, registros fotográficos e audiovisuais, conteúdos trabalhados em sala de aula e dos diversos materiais escolares dos mesmos, assim como a organização de relatórios finais entregues ao final das atividades como requisito parcial de avaliação.

Empregaram-se os indicadores da AC propostos por Sasseron e Carvalho (2008) como parâmetros analíticos e pedagógicos do efetivo alcance da alfabetização científica por parte dos alunos, os quais foram sistematicamente organizados em um quadro, cujo modelo foi proposto por Leonor (2013).

\section{RESULTADOS E DISCUSSÕES}

O estudo preliminar sobre o uso do solo no ambiente de falésias, junto aos participantes da pesquisa na fase de problematização inicial, revelou o conhecimento empírico dos estudantes em relação à região. Embora parte desses sujeitos seja de moradores daquele ambiente, foi diagnosticado um conhecimento científico insuficiente sobre esse ecossistema costeiro. A maior parte dos estudantes não soube explicar ou descrever apropriadamente o que são ambientes falésias, o que reforçou a necessidade de aproximar os conteúdos curriculares sobre "Solos" à sua realidade. Esse foi o grande desafio desta sequência didática. Chassot (2003) reforça que já não se podem conceber propostas para um ensino de ciências sem incluir nos currículos componentes que estejam orientados na busca de aspectos sociais e pessoais dos estudantes. Isso corrobora com o que diz Santos (2008), para quem é a partir da discussão de temas reais e da tentativa de delinear soluções para os mesmos que se favorece a assunção de um compromisso social pelos estudantes.

A utilização dos solos dos ecossistemas falésias para atividades agropastoris foi objeto de estudos durante todas as etapas da $\mathrm{SD}$, já que as famílias desses estudantes exercem atividades agrícolas em sistema de agricultura familiar e patronal, com prevalência da monocultura do abacaxi, do maracujá, da mandioca e da cana-de-açúcar. Os relatos dos mesmos, colhidos na fase final do trabalho, demonstraram a capacidade de vislumbrar que tais atividades agrícolas se constituem também como importantes atividades econômicas para o município e para a região de estudo, vez que Marataízes se destaca nacionalmente como um dos maiores produtores de abacaxi, figurando-se em $4^{\circ}$ lugar em produtividade deste produto. Além disso, apontam que as atividades agrícolas desenvolvidas na região de estudos não são praticadas de modo adequado e 
descrevem que o uso de agrotóxicos é frequente, sobretudo na produção do abacaxi, conforme relato a seguir:

[...] minha turma visitou a praia das falésias e, no ônibus mesmo, olhando pela janela, vimos as espécies de vegetais, inclusive as de grande interesse humano, como coqueiros, bananeiras e etc. Essas plantações são importantes para nosso município, porque é delas que os agricultores geram empregos para as pessoas conseguirem renda e sustentar suas famílias. Mas alguns agricultores não praticam o manejo adequado do solo porque usam agrotóxico (Relato de um aluno do 6o Ano do Ensino Fundamental, 2016, grifo nosso)

Esse relato é particularmente importante, pois demonstra que, além da aprendizagem de conteúdos e vocábulos próprios da ciência, essa atividade pedagógica permitiu a construção de complexas relações entre os conhecimentos sistematizados apreendidos na escola com aqueles com os quais os alunos se defrontam no dia-a-dia. Isso, de acordo com a revisão bibliográfica realizada por Sasseron e Carvalho (2008), deve ser um dos objetivos de um ensino fundado nos princípios da $A C$, pois possibilita a exploração das relações existentes entre ciência/tecnologia/sociedade/ambiente,

claramente expressas no relato do estudante, demonstrando o alcance do terceiro eixo da AC. Os alunos, por meio do depoimento, conseguiram vislumbrar que a solução instantânea de um problema, em uma das esferas citadas, pode desencadear, no futuro, o surgimento de outro problema associado a este (SASSERON; CARVALHO, 2008).

No relato feito pelos alunos em campo, o uso dos agrotóxicos no ambiente de falésias constitui uma prática frequente por agricultores de abacaxis, principalmente. Em seus discursos, os estudantes reconhecem os efeitos danosos dos agrotóxicos para a saúde e para o meio ambiente, sinalizando tal ato uma prática negativa de manejo do solo e sugerindo a sua não utilização ou a necessidade de um acompanhamento mais rigoroso do Poder Público - que no entendimento dos alunos se limita à ação interventiva de fiscalização da Prefeitura.
Quando situados na encosta do ambiente de falésias, os alunos realizaram positivamente as atividades propostas, como o reconhecimento dos componentes orgânicos e inorgânicos do solo, assim como identificaram a quantidade de horizontes (ou camadas) do perfil, apropriando-se dos conhecimentos científicos vinculados aos aspectos geológicos: formação (processos naturais químicos e físicos de intemperização dos solos), seu perfil (horizontes O, A, E, B, C), sua composição (elementos orgânicos: presença de bioturbação e inorgânicos), seus tipos (arenosos, rochosos, argilosos e humosos) e as formas de utilização antrópicas (construções civis, agricultura, agropecuária, turismo etc). Entre as espécies vivas observadas (seja no próprio quadrante ou em suas proximidades) foram identificadas as maria-farinha (Ocypode quadrata), salsa-dapraia (Ipomea pes-caprae), aroeiras (Schinus terebinthifolius), gramíneas (Poaceae sp), coruja buraqueira (Athene cunicularia), gavião carrapateiro (Milvago chimachima) e pássaros diversos tais como gaivotas e viuvinhas. Entre os elementos não vivos foram encontrados solo, água, fragmentos de rochas sedimentares, quartzo e inúmeros resíduos sólidos poluentes, como sacolas e garrafas plásticas, latas de alumínio, isopor e garrafas de vidro.

As discussões sobre o uso adequado do solo também estiveram presentes. Os estudantes conseguiram alcançar a percepção de que há um potencial paisagístico e turístico muito significativo nesse ambiente que precisa ser considerado pela população do entorno e pelos turistas, tendo em vista que a poluição e a ocupação desordenada ali presentes comprometem a qualidade ambiental das falésias e prejudica a vida marinha. Isso ficou evidente nas palavras de um estudante, ao relatar que sabe a necessidade de que todos

[...] aqueles que moram, cultivam ou que
passeiam pela região das falésias
conheçam melhor esse ecossistema, e que
modifiquem a sua atitude, pois com o
passar dos anos, a poluição poderá tornar
esse local impróprio para o cultivo, para
moradia e para o turismo (Relato de
um aluno do 6 Ano do Ensino
Fundamental, 2016).

Novamente, percebe-se, nesse relato, a maturidade do estudante ao estabelecer as 
relações entre a "postura" dos visitantes e moradores da região com o prejuízo ambiental e econômico decorrente das ações antrópicas. Nas discussões provocadas, os alunos indicaram novamente uma atuação mais efetiva do Poder Público como forma interventiva sobre o manejo do solo na região, reforçando a necessidade de maior fiscalização sobre o que é feito na região das falésias.

Nesse sentido, é possível compreender que as reflexões realizadas ao longo da atividade de campo favoreceram uma educação científica que rompeu o modelo conteudísta e compartimentalizado, ainda presente no ensino de ciências, tradicionalmente pautado na memorização de conteúdos e desconectado de questões históricas, sociais e culturais. Desse modo, considerando os trabalhos de Sasseron e Carvalho (2008) e de Chassot (2003), depreende-se que as atividades desenvolvidas ao longo da SD atingiram o objetivo de promover discussões com vistas à promoção da AC. Em outras palavras, essas atividades potencializaram meios para promover uma educação mais comprometida, de modo a permitir a compreensão do mundo ao redor, contribuindo para a busca de qualidade de vida e da transformação do mundo.

Devido à organização e estruturação da sequência didática, observou-se um envolvimento ativo dos estudantes em todas as suas fases, sobretudo na etapa de aplicação do conhecimento, que se deu sob a forma de uma aula de campo. A organização dos estudantes em grupos de trabalho favoreceu a interação entre eles, dado que trabalharam de forma colaborativa e ativa para a realização das atividades em equipe, atingindo os eixos da AC propostos por Sasseron e Carvalho (2008), conforme Quadro 1.

A aula de campo pode abarcar diferentes áreas, permitindo que educando e educadores estabeleçam trocas que propiciam interlocuções ricas. O educando adquire autonomia para a reelaboração de um novo saber científico, o que o estimula na transformação da realidade na qual está inserido. O educador intermedeia a ação pedagógica e percebe os ganhos com a quebra da hierarquia e da formalidade, contribuindo para a mudança na consciência ambiental. Para Sasseron e Carvalho (2008) a alfabetização científica não precisa somente compreender a manipulação de materiais para a resolução de problemas associados a fenômenos naturais, mas deve ensejar questionamentos e debates para que os sujeitos da aprendizagem levantem hipóteses, construam argumentos a partir de suas hipóteses, apresentem justificativas para tais constatações e consigam dar consistência para o "tema sobre o qual se investiga" (SASSERON; CARVALHO, 2008, p. 38). 
Quadro 1: Evidências da AC, organizadas em categorias, a partir de dados colhidos no transcurso da SD desenvolvida.

\begin{tabular}{|c|c|}
\hline $\begin{array}{l}\text { Categorias da } \\
\text { alfabetização } \\
\text { científica }\end{array}$ & Episódios e recortes de falas. Compreensão das atividades desenvolvidas. \\
\hline $\begin{array}{l}\text { Propõem } \\
\text { adequadamente } \\
\text { locais para } \\
\text { investigação }\end{array}$ & $\begin{array}{l}\text { A identificação das diferentes tonalidades de solo que compõem as } \\
\text { falésias evidencia claramente a diversidade de minerais que formam o sua } \\
\text { composição e perfil. Logo, constitui objeto de investigação sobre a sua } \\
\text { origem geológica, composição mineralógica e dinâmica de formação e de } \\
\text { modelação do relevo, seja por ação natural ou por ação antrópica. }\end{array}$ \\
\hline $\begin{array}{l}\text { Levantamento e teste } \\
\text { de hipóteses }\end{array}$ & $\begin{array}{l}\text { Ocorreu quando os alunos hipotetizaram que o ambiente de falésias é um } \\
\text { espaço naturalmente formado pela ação direta dos ventos marítimos e das } \\
\text { forças da maré, que bate no Barreiras e foram as escarpas, provocando } \\
\text { sua destruição. Os alunos questionaram sobre a idade do Barreiras e } \\
\text { perguntaram se o Barreiras foi a primeira coisa que os portugueses viram } \\
\text { quando chegaram ao Brasil, além do Monte Pascoal. Os alunos pensaram } \\
\text { sobre a relação entre falésia e escarpa. }\end{array}$ \\
\hline Comprovação & $\begin{array}{l}\text { Quando os alunos observaram o perfil do solo das falésias mostrando as } \\
\text { diferentes tonalidades, sugerindo sua composição variada. A mudança da } \\
\text { coloração da água mar quando toca a escarpa também foi uma evidencia } \\
\text { que os alunos identificaram, mostrando a erosão. Nesse momento, eles } \\
\text { confirmaram que ao mar é consumidor de sedimento assim como o vento, } \\
\text { agentes naturais. Os alunos também indicaram obras de estradas, casas, } \\
\text { plantações como fatores da ação antrópica sobre as falésias. }\end{array}$ \\
\hline Justificativa & $\begin{array}{l}\text { Os alunos justificaram que o mar e o vento são fortes agentes de erosão e } \\
\text { que as falésias são ambientes frágeis formadas há milhares de anos e que } \\
\text { são sensíveis às ações naturais e humanas. As diferentes tonalidades que } \\
\text { se observa em seu solo é devido aos diferentes tipos de materiais } \\
\text { presentes que também podem ser carregados pela água da chuva } \\
\text { durante o processo de infiltração. }\end{array}$ \\
\hline Explicação & $\begin{array}{l}\text { Os alunos conseguiram explicar que a configuração do relevo nas falésias } \\
\text { se deu ao longo de milhares de anos em contato com o mar, por ação das } \\
\text { forças de maré, da ação dos ventos, das chuvas de até por forças no } \\
\text { centro da terra, pois eles viram fraturas na formação Barreiras e } \\
\text { perguntaram o que era. }\end{array}$ \\
\hline Seriação dos dados & $\begin{array}{l}\text { Intemperismos (eólicos, pluviais, marítimos), erosão, ações antrópicas } \\
\text { (construções civis e atividades agrícolas), turismo e modelagem do } \\
\text { ambiente. }\end{array}$ \\
\hline Raciocínio lógico & $\begin{array}{l}\text { Os alunos relacionaram o aspecto visual do relevo no ambiente de falésias } \\
\text { às diferentes modalidades de interferências sobre ambiente costeiro. } \\
\text { Apontaram as ações naturais como as principais modeladoras do relevo } \\
\text { (portanto, formador dos solos e limitador do crescimento e } \\
\text { desenvolvimento da vegetação local). Foi também destacada a } \\
\text { contribuição da ação humana sobre a modificação do relevo e do solo, } \\
\text { sempre associado a uma determinada finalidade (construção civil, } \\
\text { agricultura, abertura de estradas, etc.). }\end{array}$ \\
\hline Prática social & $\begin{array}{l}\text { Os alunos perceberam que as falésias têm uma exuberante paisagem } \\
\text { natural, que pode ser explorada sustentavelmente por meio do turismo } \\
\text { ecológico; sofrem com as ações humanas advindas de construções civis e } \\
\text { rodoviários não planejados. O uso indiscriminado de fertilizantes e } \\
\text { agrotóxicos e a falta de preparo do solo prejudicam o ambiente costeiro. }\end{array}$ \\
\hline
\end{tabular}

Fonte: Elaborado pelos autores conforme Sasseron e Carvalho (2008) e Leonor (2013). 


\section{CONSIDERAÇÕES FINAIS}

A aula de campo nas falésias pode ser estruturada de modo a contrapor o modelo de educação bancária gerando, a partir dela, uma visão crítica do ambiente. Desse modo, o entendimento das relações entre Ciência, Tecnologia, Sociedade e Ambiente pode ser mais facilmente alcançado por meio de debates socioambientais.

$\mathrm{Na}$ atividade desenvolvida foi possível dialogar os conhecimentos a partir da proposição de uma metodologia ativa para o ensino de conteúdos científicos curriculares. Atividades assim podem ajudar na formação dos estudantes para a cidadania, para a superação da curiosidade ingênua e para a compreensão holística dos processos circunscritos no ambiente, provocando rupturas e desafios.

A partir dos conhecimentos tácitos dos estudantes, foram promovidas ações pedagógicas que possibilitaram não apenas uma exposição dos conhecimentos curriculares de Ciências, mas sua interlocução com aspectos sociais, culturais, econômicos e políticos. Além disso, destacase o fato de que a aula de campo permitiu a valorização das experiências de vida individuais dos alunos à medida que eram

\section{REFERÊNCIAS}

[1] Chassot, A. Alfabetização científica: uma possibilidade para inclusão social. Revista Brasileira de Educação. n.22. jan - abr, p. 80-99 2003.

[2] Delizoicov, D.; Angotti, J. A.; Pernambuco, M. M. Ensino de ciências: fundamentos e métodos. São Paulo: Cortez, 2002.

[3] Leonor, P. B. Ensino por investigação nos anos iniciais: análise de sequências didáticas

[4] de ciências sobre seres vivos na perspectiva da alfabetização científica. Vitória, 192p. 2013. Dissertação (Mestrado) - Instituto Federal do espírito Santo.

[5] Nunes, F. C.; silva, E. F. Grupo Barreiras: características, gênese e evidências de neotectonismo. Rio de Janeiro: Embrapa Solos, 2011. relatadas suas vivências pessoais e familiares com e na região estudada, aproximando o conhecimento empírico desses sujeitos ao conhecimento escolar e científico nas diferentes situações propostas pelas atividades. É nesse sentido que a alfabetização científica se legitima e ganha força, reforçando não apenas a necessidade de (in)formar os pequenos cidadãos, mas também torná-los aptos a (in)formar seus familiares e demais sujeitos que tiverem a oportunidade de ouvi-los, seja em seus negócios familiares, seja em suas comunidades ou, ainda, onde for possível dar continuidade à alfabetização científica popular.

Nessa perspectiva, entende-se que as aulas de campo em ambiente costeiro podem contribuir de forma significativa para a aprendizagem de diversos conteúdos associados ao ensino de Ciências, de modo a proporcionar uma noção holística do ambiente e a favorecer a tomada de consciência crítica quanto os processos de intervenção antrópica nos ambientes naturais.

[6] Santos, W. L. P. Educação Científica humanística em uma perspectiva Freireana: Resgatando a função do ensino de CTS. Alexandria, 1(1), 109-131, 2008.

[7] Sasseron, L. H.; Carvalho, A. M. P. Almejando a Alfabetização Científica no Ensino Fundamental: a proposição e a procura de indicadores do processo. Investigações em Ensino de Ciências, Porto Alegre, v. 16, n. 1, p. 59-77, 2008.

[8]Seniciato, T; Cavassan, O. Aulas de campo em ambientes naturais e aprendizagem em ciências um estudo com alunos do ensino fundamental. Ciência \& Educação, v. 10, n. 1, p. 133-147, mar. 2004. 


\section{Bapítulo 6}

\section{A APRENDIZAGEM CONCEITUAL ACERCA DA CONDUTIVIDADE ELÉTRICA DAS SUBSTÂNCIAS ATRAVÉS DE HABILIDADES DESENVOLVIDAS PELA EXPERIMENTACָ̃O}

\section{Carlos Eduardo Pereira Aguiar}

\section{Roberto Barbosa de Castilho}

Resumo: $O$ presente trabalho é um estudo baseado no emprego da experimentação como ferramenta estratégica para o processo de ensinoaprendizagem de Ciências e Química, em estudantes do 9o ano de uma escola pública do município de Manaus. O objetivo principal foi verificar se a experimentação poderia contribuir para um ensino que desenvolvesse habilidades, bem como, minimizasse os obstáculos epistemológicos, em discentes participantes da Olimpíada Brasileira de Química Júnior-OBQJr, acerca dos conceitos da condutividade elétrica dos materiais e substâncias presentes no cotidiano. A abordagem metodologia aplicada foi qualitativa, tendo como instrumento de coleta de dados questionários com questões abertas e fechadas e, cujo resultado demonstrou que a experimentação pode ser uma potencial ferramenta no desenvolvimento das habilidades necessárias à superação de obstáculos epistemológicos que dificultem uma aprendizagem efetiva dos conceitos químicos sobre o tema, potencializando a motivação e o interesse dos estudantes em participar ativa e criticamente das aulas de Química.

Palavras chave: Conhecimento científico, experimentação, habilidades, obstáculos epistemológicos. 


\section{INTRODUÇÃO}

A prática educativa, no cotidiano escolar, tem mostrado que muitas das dificuldades de aprendizagem dos conceitos científicos, principalmente os fundamentais da Química segundo relatos dos professores dessa disciplina, decorrem da falta de motivação e do desinteresse dos discentes. Essas observações, na sala de aula, são objetos de pesquisas científicas, que atribuem como possíveis causas alguns fatores extrínsecos como a falta de aulas mais prazerosas e envolventes como, por exemplo, as de atividades experimentais.

De acordo com Pinho-Alves (2000), a atividade experimental é bem aceita pela maioria dos professores que afirmam que o laboratório didático de Ciências, pode promover a motivação e despertar o interesse dos discentes, podendo contribuir com a aprendizagem conceitual, pois se trata de uma atividade muito rica e próspera para a aprendizagem dos estudantes. As vantagens de se utilizar as atividades experimentais no ensino de Química são ressaltadas pela literatura em inúmeros trabalhos (HIGA e OLIVEIRA, 2012; GIORDAN, 1999), ressaltando que deve relacionar os fenômenos a teorias que os explique e vinculadas à realidade do discente, conectando suas experiências prévias ao seu pensamento reflexivo (SILVA et al, 2010).

Cabe salientar que ao propor a experimentação como estratégia de ensino de Ciências e Química, deve-se atribuir-Ihe a função de instrumento facilitador da construção e/ou ressignificação de conceitos e modelos, 0 que contribui com 0 desenvolvimento do conhecimento científico. De acordo com Gaston Bachelard (1996), o conhecimento científico não se desenvolve quando não se superam obstáculos intimamente enraizados no próprio ato de conhecer.

\section{A EXPERIMENTAÇÃO E AS COMPETÊNCIAS E HABILIDADES}

Segundo os Parâmetros Curriculares Nacionais-PCN (BRASIL, 1998), Parâmetros Curriculares para o Ensino Médio-PCNEM (BRASIL, 1999) e Orientações Curriculares para o Ensino Médio-OCNEM (BRASIL, 2006), o ensino dos conteúdos de Química deve embasado em práticas experimentais direcionadas para o que ele já consegue fazer, com vistas ao desenvolvimento de competências e habilidades que o auxiliem na interpretação e resolução de problemas do mundo em que vive. Em conformidade com o que orientam os documentos oficiais o ensino deixa de ser centrado apenas no conhecimento (RICARDO; ZYLBERSZTAJN, 2002).

O desenvolvimento de competências e habilidades tem como objetivo capacitar os estudantes para a realização da leitura e interpretação de situações próximas à sua realidade, que face as suas complexidades, obrigam o sujeito a utilizar um pensamento complexo que o auxilie na correção de eventuais problemas presentes no seu cotidiano (ZABALA e ARNAU, 2010). O pensamento complexo, referido pelos autores, constituído pelos princípios fundamentais do conhecimento científico, é responsável pelo chamado "agir competente", que pode ser alcançado através da mediação pela experimentação. Santos e Schenetzler (1998) destacam que para tomar uma decisão, o cidadão precisa ter informações e capacidade crítica para decidir, avaliando os custos e benefícios dessa decisão.

\section{A EXPERIMENTAÇÃO E OS OBSTÁCULOS EPISTEMOLÓGICOS}

Os obstáculos epistemológicos, no ensino de Ciências e Química, têm estreita relação com as dificuldades de aprendizagem de conceitos científicos, pois os discentes trazem consigo, conhecimentos prévios ou comuns, sem nenhum caráter científico e que obstruem a sua formação conceitual.

Segundo Kummer (1999), o conhecimento comum é aquele que decorre das informações transmitidas a um indivíduo por um grupo social, de geração a geração, que se opõe à racionalidade da Ciência, pois é ametódico e não submetido a um estudo crítico. Diante disso, compreender que a Ciência evolui de forma descontínua, se torna imprescindível, enfatizando o embate entre a observação e a experimentação. O avanço do conhecimento depende da ruptura entre o conhecimento comum e o conhecimento científico (DOMINGUINI E SILVA, 2010).

A utilização da experimentação como uma das estratégias metodológicas, no ensino de Ciências e Química, pode contribuir na superação de obstáculos epistemológicos, como as generalizações, construídos pela 
experiência primeira que termina por produzir o que se denomina conhecimento comum ou prévio (BACHELARD, 1996). De acordo com Gomes e Oliveira (2007) quando o indivíduo faz uso de uma generalização, com o fim de facilitar sua compreensão acerca do real, refuta a busca por um conhecimento mais aprofundado, que dê sentido e precisão a certo fenômeno, conduzindo-o a uma natural desmotivação.

Neste estudo o problema da pesquisa teve como enfoque a necessidade de compreender a ocorrência e os fundamentos físico-químicos da condutividade elétrica, que permitisse 0 entendimento de muitos fenômenos que ocorrem cotidianamente na vida de um indivíduo, tais como a transmissão da eletricidade por meio de redes de alta tensão, a eletrólise e o entendimento do funcionamento de pilhas e baterias, necessários à formação de cidadãos críticos e conscientes, epistemologicamente e, cuja aplicação na resolução de problemas, depende da construção do seu conhecimento científico.

Diante do exposto, em um primeiro momento, este estudo, buscou averiguar as concepções dos estudantes acerca da condutividade elétrica e, em um segundo momento utilizar uma atividade experimental como uma ferramenta de promoção de discussões e apropriações de conceitos envolvidos na condutividade elétrica por parte dos estudantes. A partir das reações e dos registros dos estudantes, procurou-se verificar a eficiência ou não da experimentação como estratégia metodológica que auxilie a superar os obstáculos epistemológicos do conhecimento comum e apreensão de conceitos, a partir do momento em que, efetivamente e continuamente, seja aplicada em sala de aula.

\section{EXPERIMENTAÇÃO NOS DOCUMENTOS OFICIAIS E A EDUCAÇÃO ESCOLAR}

Os documentos oficiais da educação básica norteiam que o ensino de Ciências da Natureza, onde está inserida a Química seja abordado sob o regime interdisciplinar, em conexão com a tecnologia e sociedade, com ênfase para a formação da cidadania com enfoque social contextualizado.
Ao contrário do que preconizam os citados documentos, nas escolas públicas, a experimentação não é vista como uma atividade fundamental para a formação do discente. A falta de laboratório de Ciências, a falta de tempo e o despreparo dos professores são justificativas comuns para não serem realizadas no ambiente escolar. Além disso, o professor e a escola entendem como necessidade, apenas, uma problematização e discussão dos conteúdos para a verbalização de conceitos (GIORDAN, 1999). Na possibilidade de realizar uma aula experimental, esta não deve ter uma abordagem demonstrativa e infalível.

Havendo a ocorrência de erro, este deve ser considerado por conter informações relevantes do fenômeno, pois aponta para novos procedimentos que determinem sua correção e, consequente redução de obstáculos epistemológicos. Segundo Kummer (1999) (apud DOMINGUINI E SILVA, 2010), fundamentado na teoria bachelardiana, ao se corrigir ou retificar o erro, chega-se à verdade, e a Ciência se mostrará viva, o que faz com que, a partir de então, todo o saber científico possa ser reformulado.

Segundo Silva et al. (2010), a experimentação deve estabelecer uma relação entre fenômenos e teorias, levando em conta a realidade do estudante, procurando estabelecer uma conexão entre as experiências cotidianas e o pensamento reflexivo. A atividade experimental não deve ser desvinculada de situações reais, por estimular e despertar 0 interesse dos discentes nos temas propostos pelos professores, que serão apenas os mediadores da atividade procedimental (ABRAHAM et al., 2009).

\section{METODOLOGIA}

O presente trabalho foi desenvolvido pelo pesquisador, na condição de representante de uma escola pública municipal da cidade de Manaus-AM, junto à coordenação da Olimpíada Brasileira de Química JúniorOBQJr, em 2016, como parte das aulas de aprofundamento dos conteúdos de Química, para 18 (dezoito) estudantes, voluntários, de um total de 29 (vinte e nove), do 9o ano do Ensino Fundamental II, que apresentavam dificuldades de aprendizagem do conteúdo 
propriedades das substâncias iônicas, moleculares, metálicas e a condutividade elétrica.

A metodologia da pesquisa teve uma abordagem qualitativa e os dados foram coletados através de dois questionários, pré e pós a realização de um experimento. A partir do questionário pré, num primeiro momento, foi possível realizar o levantamento dos conhecimentos prévios, das dificuldades de aprendizagem e, ainda, identificar os possíveis obstáculos epistemológicos, porventura existentes.

Num segundo momento, foi realizada uma atividade experimental, a partir da construção de circuito elétrico, para investigar qual das substâncias/materiais permitiria a passagem da corrente elétrica. De acordo com PinhoAlves (2000), numa abordagem investigativa, contrariamente à tradicional, o indivíduo participa ativamente, é motivado e desafiado a buscar respostas adequadas para um problema científico e tem a liberdade de elaborar e testar hipóteses como tentativa de soluções.

O terceiro momento foi realizado com a aplicação do questionário pós, composto pelas duas questões discursivas do questionário pré, tendo como finalidade verificar se a atividade experimental teria sido suficiente para promover uma possível modificação dos conhecimentos dos estudantes e, de que forma ocorreu ou poderia ter ocorrido essa modificação. Não obstante, serviu, ainda, para sinalizar uma possível superação ou não obstáculos epistemológicos, casualmente, evidenciados no primeiro momento.

Os instrumentos de coleta (questionários), elaborados pelo pesquisador, foram compostos por questões fechadas e abertas, abordavam definições e situações acerca de circuito elétrico, corrente, intensidade e fluxo de corrente elétrica e da condução ou não da corrente elétrica em substâncias/materiais como: sal de cozinha, solução de sal de cozinha, sacarose, solução de sacarose, água de poço artesiano, ferro, plástico, água com sabão e urina. Em uma das questões fechadas os estudantes deveriam marcar a opção "conduz" ou "não conduz", para cada uma das substâncias/materiais; nas abertas deveriam: 1) Explicar o porquê de algumas substâncias/materiais permitirem a passagem de corrente elétrica e outras não. 2) Descrever a condição quimicamente necessária para que houvesse a condução da corrente elétrica.

\section{RESULTADOS E DISCUSSÃO}

\subsection{PRIMEIRO MOMENTO CONSIDERAÇÕES DAS CONCEPÇÕES INICIAIS DOS ESTUDANTES SOBRE O TEMA.}

O tema condutividade elétrica foi escolhido por contemplar alguns conceitos básicos de suma importância para a compreensão de dispositivos e circuitos elétricos, que permitem uma abordagem pautada no cotidiano dos discentes, a partir de uma introdução em nível fenomenológico e posterior discussão das formas mais microscópicas, sempre levando em consideração as relações intercambiáveis entre teoria e prática.

Os resultados obtidos através do questionário possibilitaram a identificação de importantes concepções cotidianas dos estudantes acerca do tema abordado. Dos dados das questões fechadas mereceram a nossa atenção as respostas dadas para o sal sólido, para a sacarose sólida, para a água de poço artesiano e para a urina, conforme mostra a tabela 1. Causou surpresa o fato de que a maioria dos estudantes identificar o sal sólido e a sacarose como condutores elétricos, o que demonstra que muitos dos discentes desconheciam suas características estruturais, além da pouca compreensão a respeito do fenômeno de condutividade elétrica.

Com respeito à condutividade da água, grande parte lhe atribui uma capacidade de condução elétrica. Este resultado foi tema de discussões entre os discentes, haja vista que alguns relataram terem visto nos filmes e em diversas atrações de TV, pessoas recebendo descargas elétricas quando se encontravam em banheiras cheias de água. Este é um reflexo da exposição a que os estudantes são submetidos em seu cotidiano, pois na grande maioria das vezes assimilam estas imagens sem entender realmente o motivo pelo qual isto ocorre. Com relação à urina, a minoria que supôs que a substância poderia permitir a passagem da corrente elétrica, possivelmente, o fez, não por entender e conhecer sua composição, mas por terem sido movidos a manifestar uma resposta efusiva, concebida a conhecimentos intuitivos e imediatos 
Tabela 1. Porcentagem de estudantes que responderam nas questões objetivas que as substâncias/materiais conduziriam a corrente elétrica.

\begin{tabular}{|c|c|c|c|c|c|c|c|c|}
\multicolumn{4}{c}{$\mathrm{NaCl}$} & \multicolumn{3}{c}{ Açúcar } & \multicolumn{3}{c|}{ Água } & Água \\
(Poço) & (Sabão) & Urina \\
\hline 72,2 & 33,3 & 50,0 & 50,0 & 94,4 & 16,7 & 77,8 & 77,8 & 11,1 \\
\hline
\end{tabular}

A experiência com a realidade fenomenológica, segundo Bachelard, pode originar ideias que conduzem "o pensamento científico" para construções mais metafóricas do que reais, impedindo o pensamento abstrato, fundamental para o desenvolvimento do pensamento científico que, em consequência, pode se transformar num obstáculo à formação do conhecimento científico.

Evocando os obstáculos epistemológicos, a concepção dos estudantes acerca da condutividade elétrica da água pode ser categorizada, de acordo com o que Bachelard denominou de "Experiência Primeira", onde um resultado passível de verificação macroscópica torna-se argumento para o estabelecimento de uma "Verdade".

O obstáculo da experiência primeira aparece como um eterno obstáculo inicial a cultura científica pelo fato de

oferecer uma satisfação imediata à curiosidade, de multiplicar as ocasiões de curiosidade, em vez de benefício pode ser um obstáculo para a cultura científica. Substitui-se o conhecimento pela admiração, as ideias pelas imagens. (BACHELARD, 1990, apud PARENTE, p. 36, 1990).

Figura 1

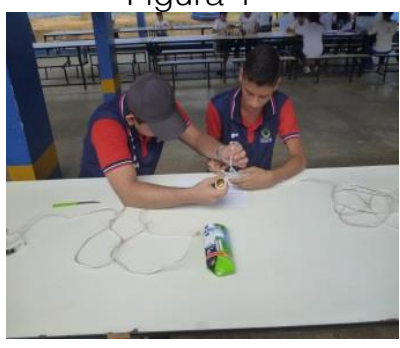

Figura 2

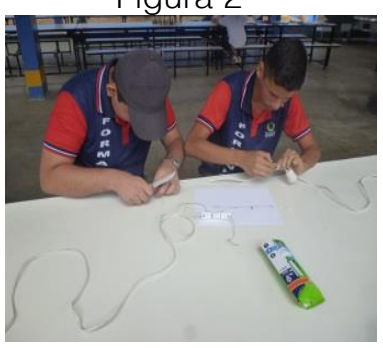

\subsection{SEGUNDO MOMENTO - ATIVIDADE EXPERIMENTAL DE CONDUTIVIDADE ELÉTRICA.}

Após discussões, tentativas e erros, 04 (quatro) estudantes montaram o circuito teste para verificar a condutividade elétrica nos materiais/substâncias. Nesta etapa da pesquisa, os estudantes puderam entender 0 conceito de circuito elétrico aberto e fechado, bem como a função de um interruptor de luz, do botão liga/desliga dos eletrodomésticos. $O$ teste de condutividade foi relevante para desfazer algumas crenças e generalizações que culminaram em obstáculos inerentes à "Experiência Primeira", a respeito da energia elétrica e de sua condutibilidade por parte da matéria, particularmente em relação à água de poço artesiano, conforme discutido no primeiro momento. Além disso, colaborou com a apreensão do conhecimento sobre o movimento dos elétrons, com o desenvolvimento de habilidades concernentes aos esquemas elétricos e às características das substâncias/materiais analisados.

Realização da atividade experimental sobre eletricidade: i) Discussão e montagem de um circuito elétrico pelos estudantes; ii) Teste de condutividade elétrica dos materiais. 


\subsection{TERCEIRO \\ MOMENTO CONSIDERAÇÕES DAS CONCEPÇÕES FINAIS DOS ESTUDANTES SOBRE O TEMA.}

Em termos das explicações dos educandos sobre 0 porquê algumas substâncias/materiais permitiriam a passagem da corrente elétrica e outras não, em cada situação proposta no questionário, foram organizadas quatro categorias das respostas obtidas. Para a categorização, levou-se em conta o significado das respostas dadas pelos discentes, uma vez que são poucos os trabalhos que abordam o tema condutividade elétrica, como mostrado a seguir.

Categoria 1 - Condução de energia/eletricidade - Nesta categoria incluíram-se as respostas mais simples, as quais se limitaram a afirmar que a condição para a transmissão ocorreria, exclusivamente, pela condução de energia/eletricidade dos materiais, não fazendo inferência do porque disso.

"Por ser substâncias que conduzem energia."

"Devido a condução de eletricidade."

As respostas mais simples e de maior ocorrência $(77,8 \%)$ ocuparam esta categoria 1. O grande número dos estudantes que simplesmente respondeu a questão atribuindo à capacidade de permitir a passagem de corrente, tão somente à condução de energia/eletricidade, refere-se à manifestação de conhecimentos intuitivos e imediatos, que imobilizam o pensamento e fornecem respostas evasivas e gerais a qualquer questionamento (ANDRADE e FERRARI, 2002). Bachelard chamou tais ideias de "conhecimento geral", pois são indicativos de uma visão superficial e fragmentada do tema por parte dos estudantes, que na maioria das oportunidades não concebem o significado dos termos usados.

Categoria 2 - Condução de energialeletricidade promovida por cargas elétricas - Nesta categoria foi referida a existência de cargas que facilitam a condução da eletricidade sem, no entanto, mencionar quais são e o que são as referidas cargas.
"As substâncias que conduzem a corrente elétrica possuem cargas, já as não condutoras não possuem cargas."

"Devido ao movimento das cargas elétricas."

Nesta categoria, $11,1 \%$ dos discentes dissertaram que a capacidade de transmissão da corrente se devia à presença de cargas capazes de permitirem a condução de eletricidade. Apesar disso, que o conhecimento dos estudantes não sustenta de maneira sólida o significado do termo "carga", tão importante ao estudo do fenômeno de condutividade. Em decorrência, da falta de uma interpretação e discussão destes conhecimentos, estes culminam em intuições, através das quais os estudantes concebem uma teoria desprovida de questionamentos e meramente superficial.

No século XVIII, segundo exemplifica Bachelard, a noção de eletricidade embasada em uma primeira visão empírica, não retratava exatamente os fenômenos. Esta afirmação é decorrente de estudos empíricos realizados por Joseph Priestley sobre a eletricidade, em 1768 e, que citada por Bachelard (1996, p. 38) mostra bem a realidade da época:

Se alguém chegasse a prever a condução elétrica por meio de algum raciocínio, teria sido considerado um gênio.

Categoria 3 - Classificação das cargas elétricas em elétrons e íns - Incluiu-se nesta categoria as respostas que especificavam os tipos de cargas existentes, embora sem uma diferenciação entre "cargas", "íons" e "elétrons", mas que explicavam a permissão da passagem da corrente elétrica com base na existência de cargas elétricas.

"Os elétrons fluem fazendo com que se sinta a eletricidade."

"Os materiais condutores tinham cargas positivas e negativas, e os que não conduzem não tinha íons."

Nesta categoria, a quantidade de estudantes $(11,1 \%)$ que condicionou a condução de eletricidade à existência de íons ou elétrons, não demonstraram conhecer os conceitos aqui discutidos. Novamente pode-se evidenciar uma confusão entre os termos cargas e elétrons, demonstrando uma visão fragmentada dos conceitos, provocada pelo emprego equivocado dos termos químicos. Essa situação não é exclusiva dos estudantes, pois comumente os livros 
descrevem a corrente elétrica como "movimento/fluxo de cargas elétricas" e, muitas vezes, não deixam claro o que são estas cargas.

O obstáculo percebido é conhecido por "obstáculo verbal", ou seja, associado à linguagem, que decorre da retirada de conceitos científicos do contexto histórico, limitando-o a definições restritas. O não conhecimento da gênese histórica dos conceitos, ou não preocupação com os erros, induzirão os estudantes a não explicitarem seu processo de construção dos conceitos. Portanto, além de um problema epistemológico, o uso dos termos cargas e elétrons como sendo intercambiáveis são equívocos conceituais que podem ser induzidos nos estudantes pelo fato de não se explicitar o processo histórico de construção dos conceitos (Lopes, 1996).

Categoria 4 - Condução de energia/eletricidade devido a presença de ions em solução e de elétrons em materiais sólido - As respostas de maior grau de complexidade conceitual, ainda que no primeiro momento metodológico não se tenha evidenciado nenhuma, poderiam ser classificada nesta categoria.

Em relação à categoria mais elaborada conceitualmente, se verificou que antes da atividade experimental nenhum dos discentes foi capaz de descrevê-la apropriadamente. Aliada à complexidade dos conhecimentos mais profundos acerca do fenômeno, a maior dificuldade apresentada foi à incapacidade de organização e explicitação clara das ideias.

\section{CONSIDERAÇÕES EM RELAÇÃO À APRENDIZAGEM.}

Os dados sugerem que pode ter ocorrido aprendizado dos conteúdos fundamentados e discutidos, apesar dos obstáculos epistemológicos e o possível desenvolvimento de suas habilidades com relação à condutividade ou não da eletricidade, pois a experimentação demonstrou claramente quais seriam ou não os condutores. Há indicadores de possível mudança conceitual, com possível redução dos efeitos da experiência primeira, pois a atividade experimental foi realizada com questionamentos sistemáticos durante cada passo do procedimento.
No que tange aos conhecimentos conceituais quanto à condição necessária para a facilitação do fluxo de elétrons, pode-se observar uma melhoria na apreensão do conteúdo e, ainda que não tenha sido unânime, entendeu-se que a atividade experimental atendeu, em grande parte, às expectativas quanto à promoção de um aprendizado relevante dos conceitos químicos.

Vale destacar aqui o discurso verbal de um dos estudantes, quando observou 0 acendimento da lâmpada, após a introdução dos terminais na urina:

"Professor se lâmpada acendeu ao testar a urina, então ela é uma substância iônica! Logo nós somos iônicos, e está explicado porque levamos choque ao tocar em fios descascados ou ao recebermos uma descarga elétrica!"

Diante dessa afirmação, pode-se perceber que, embora não esteja adequada quanto ao conhecimento dito como científico, demonstra que o estudante compreendeu que a passagem da corrente elétrica, está diretamente ligada à presença de íons nas substâncias não metálicas, e permitiu ao discente compreender a razão pela qual o nosso corpo está propenso às descargas elétricas, inclusive permeando conhecimentos que o leve à prevenção de situações perigosas envolvendo a eletricidade.

\section{CONSIDERAÇÕES FINAIS}

Primeiramente, inferimos que a pesquisa foi suficiente para revelar que a maioria dos estudantes demonstrou muito interesse e curiosidade pelos fenômenos estudados em Química, chegando a se mostrarem ansiosos pelas aulas de aprofundamento para a OBQJr, haja vista que devido a ausência de um laboratório de Ciências na escola, as aulas ministradas pelo professor da disciplina ocorriam sob a forma tradicional.

Secundariamente, uma segunda inferência pode ser destinada aos resultados da pesquisa. Em um primeiro instante se poderia dizer que o conhecimento dos discentes acerca da condutividade elétrica evoluiu após a atividade realizada, o que era o objetivo maior do trabalho. Basicamente o que pode ser inferido é que a abordagem experimental influenciou numa construção mais crítica do conhecimento e, os estudantes foram 
capazes de elaborar uma visão bem mais completa do fenômeno, abandonando em parte a superficialidade do início. Alguns até apresentaram ideias bem próximas das aceitas cientificamente.

Entretanto, os resultados também mostram que uma parte dos estudantes não compreendeu por completo o fenômeno de condução elétrica, devido a dificuldades na compreensão de outros conceitos e na organização das ideias já possuídas. Diante do exposto, sugerimos que a abordagem da condutividade elétrica, seja desenvolvida por

\section{REFERÊNCIAS}

[1] Abraham, M. R. et al. The nature and state of general chemistry laboratory courses offered by colleges and universities in United States. Journal of Chemical Education, v. 74, n. 5, p. 591-594, 1997.

[2] Andrade, B.L; FERRARI, N. As analogias e metáforas no ensino de ciências à luz da epistemologia de Gaston Bachelard. Ensaio Pesquisa em Educação em Ciências, v.2, n. 2, dez., 2002.

[3] Bachelard, G. A formação do espirito científico: contribuição para uma psicanálise do conhecimento. $2^{2}$ reimpressão. Contraponto: Rio de Janeiro, 1996.

[4] Brasil. Ministério da Educação. Secretaria de Educação Fundamental. Parâmetros Curriculares Nacionais: Ciências Naturais. Brasília: MEC/SEF, 1998.

[5] Ministério da Educação. Secretaria de Educação Média e Tecnológica. Parâmetros Curriculares Nacionais para o Ensino Médio. Brasília: MEC/SEMTEC, 1999.

[6] Ministério da Educação. Secretaria de Educação Básica. Orientações Curriculares para o Ensino Médio: Ciências da Natureza, Matemática e suas Tecnologias. Brasília: MEC/SEB, 2006.

[7] Dominguini, L.; SILVA, I. B. da. Obstáculos à construção do espírito científico: Reflexões sobre o livro didático. In: V CINFE, Caxias do Sul, RS, Maio 2010.

[8] Giordan, M. O papel da experimentação no ensino de ciências. Química Nova na Escola, Rio de Janeiro, nr 10, p. 46, 1999.

[9] Gomes, H. J. P.; OLIVEIRA, O. B. de. Obstáculos epistemológicos no ensino de ciências: um estudo sobre suas concepções de átomo. Ciência \& Cognição, Ano 04, v. 12, Dez 2007. Disponível em: www.cienciaecognicao.org. Acesso em: 21 de março, 2016. práticas experimentais alicerçadas por enfoques históricos e, principalmente, pautadas em perguntas e discussões. O presente trabalho também serve de parâmetro para a continuidade do estudo, o qual buscará sanar as lacunas conceituais ainda existentes nos estudantes após esta pesquisa.

\section{AGRADECIMENTOS}

Ao gestor, ao professor de Química e aos discentes da escola pública.

[10] Higa, I.; OLIVEIRA, O. B. de. A experimentação nas pesquisas sobre o ensino de Física: fundamentos epistemológicos e pedagógicos. Educar em Revista, Curitiba, Brasil, n. 44, p. 75-92, abr/jun, 2012. Editora UFPR

[11] Kummer, T. Conhecimento, conhecimento científico e conhecimento do senso comum. Revista Roteiro, Ed. UNOESC: v. 22, n. 42, p. 4556, 1999.

[12] Lopes, A.R.C. Potencial de Redução e Eletronegatividade: Obstáculo Verbal. Química Nova na Escola, n. 4, p. 21-23, nov., 1996.

[13] Parente, L.T.S. Bachelard e a Química no ensino e na pesquisa. 1aㅡ ed. Fortaleza: Ed. da Universidade Federal do Ceará/Stylus Publicações, 1990.

[14] Pinho-Alves, J. F. Regras da Transposição Didática Aplicadas ao Laboratório Didático. Caderno Catarinense de Ensino de Física, Florianópolis, v.17, n. 2, p.174-182, 2000.

[15] Priestley, J. Familiar to the Study of Electricity. Londres: J. Dosdley; T. Cadell; Johnson e Payne, 1768.

[16] Ricardo, E.C.; Zylbersztajn, A. O ensino das ciências no nível médio: um estudo das dificuldades da implementação dos parâmetros curriculares nacionais. Cad.Bras. Ens. Fís., v. 19, n. 3:p. 351-370, dez, 2002.

[17] Santos, W. L. P. dos; Schnetzler, R. P. Ciência e educação para a cidadania. In: CHASSOT, A.; Oliveira, R. J. (Orgs.). Ciência, ética e cultura na educação. São Leopoldo: Editora Unisinos, 1998. p.255-270.

[18] Silva, R. R.; Machado, L. P. F.; Tunes, E. Experimentar sem medo de errar. In: SANTOS, W. L.; Maldamer, O. A.: (Org.). Ensino de Química em foco. ljuí (RS): Unijuí. p. 231-261, 2010.

[19] Zabala, A.; ARNAU, L. Como aprender e ensinar competências. Tradução Carlos Henrique Lucas Lima, Porto Alegre, Artmed, 2010. 197p. 


\section{Capítulo 7}

\section{MOMENTO QUIMICO: REFLEXÕES SOBRE UM JORNAL DE DIVULGACÃO CIENTÍFICA NO ÂMBITO DE UM CURSO DE LICENCIATURA EM QUIMICA}

\section{Brenno Ralf Maciel Oliveira}

\section{Tatiana Comiotto}

\section{Fabíola Sucupira Ferreira Sell}

Carlos Eduardo Rocha

\section{Duan Ceola}

\section{Maria Elise Sonnenhohl}

\section{Isadora Jorge Velloso}

Resumo: O presente trabalho discute sobre uma pesquisa realizada com 107 licenciandos em Química que responderam a um questionário acerca do jornal Momento Químico. Buscou-se investigar os desdobramentos dessa circulação e as motivações/interesse dos leitores pelos textos e temas das edições do jornal. Os resultados evidenciaram que os leitores utilizam o jornal para se informar, aprender e saber mais sobre temas científicos e assuntos locais da universidade. Os alunos classificaram os textos do jornal como de fácil compreensão, pouco formais, com quantidade adequada de conteúdos científicos e fontes. Além disso, uma parte considerável afirmou já ter aprendido algo lendo o jornal e que considera totalmente possível de utilizá-lo nas aulas de Química no ensino médio. Portanto, o jornal tem cumprido seu papel na divulgação científica, promovendo maior interesse dos estudantes pela leitura científica e permitindo a construção de conhecimentos em ambientes que ultrapassam as fronteiras da sala de aula.

Palavras chave: Ensino de Química, Popularização da Ciência, CTS, Jornal Científico 


\section{INTRODUÇÃO}

As mudanças sofridas nas esferas da ciência, da tecnologia e da sociedade interferem diretamente o ambiente e as condições de vida dos seres humano. Além disso, tais esferas influenciam-se entre si em uma relação indissociável que transforma também o modo com que se deve ensinar ciências nas escolas.

Nesta perspectiva, coloca-se aos educadores o desafio de inserir os estudantes plenamente na sociedade, fazendo com que estes sejam capazes de atuar e intervir de forma autônoma e crítica em sua realidade (LOPES e SILVA, 2009).

A educação em ciências é, atualmente, uma inquietação essencial em diferentes países do mundo, cujo destaque no ensinoaprendizagem desta área de conhecimento se baseia no avanço tecnológico e científico, bem como a constituição de sociedades democráticas para o desenvolvimento de especialistas altamente qualificados (BRASIL, 1998). Entretanto, a compreensão das ciências e da tecnologia como se oferece atualmente, estabelece que os sujeitos detenham conhecimentos interdisciplinares que não poderão ser produzidos exclusivamente sob a influência do ensino formal realizado nas escolas (BASTOS, 2004).

Neste cenário, os espaços não formais de aprendizagem podem influenciar significativamente na compreensão de mundo que cada indivíduo constrói, bem como a maneira com que compreende e relaciona conceitos científicos no entendimento acerca do universo em que está inserido.

O ensino de ciências é uma prática social que vem sendo cada vez mais expandida nos espaços não-formais de educação e nas distintas mídias. Há uma concordância em relação à necessidade de se elaborar políticas e metodologias que efetivamente ajudem na apreensão do conhecimento científico, por meio de experiências fora da escola (FALK \& DIERKING, 2002; JENKINS, 1999).

A educação não-formal refere-se a aprendizagem de conteúdos por meio de metodologias que partem da cultura dos sujeitos e dos grupos, nascendo da problematização da vida cotidiana; os conteúdos surgem de assuntos que se assentam em necessidades, carências, provocações, limitações ou ações empreendedoras a serem realizadas (GOHN, 2006).

Segundo Fávero (2007), a educação nãoformal é uma experiência educacional constituída e ordenada que ocorre fora do sistema formal de ensino para promover distintos tipos de aprendizagem a subgrupos da população.

Neste sentido, iniciativas na educação em espaços não-formais de aprendizagem também podem contribuir para a formação do indivíduo, bem como para sua conscientização e compreensão de conceitos científicos que são ensinados na escola. Em especial, as ferramentas que preconizam a divulgação científica a partir de veículos que ultrapassam os limites da sala de aula, vêm apresentando bons resultados no acesso a informação e na construção de conhecimentos científicos.

Após a revolução industrial, houve um crescente desenvolvimento da ciência e da tecnologia e, com isso, também cresceu a influência do meio científico na vida e no cotidiano das pessoas, bem como nas políticas públicas (MOURA, 2003). Dessa forma, se torna ainda mais necessário ampliar - acesso à informação e também aos conhecimentos científico-tecnológicos, de modo que sejam utilizados para embasar as atitudes dos indivíduos no dia a dia, de maneira consciente e criativa.

O uso de textos para divulgação científica tem sido documentando há vários anos, em especial como prática pedagógica em inúmeras instituições de ensino (SILVA, 2006). A intenção e objetivo desse tipo de texto é escrever de forma que todos possam compreender e tornar a ciência popular. Para isso, é importante transpor as informações de caráter científico por meio de textos, desenhos, imagens, fazendo com que as informações se tornem acessíveis a qualquer tipo de leitor, inclusive aqueles considerados iniciantes.

Uma das formas para se estimular a divulgação científica é o uso de jornais e/ou seções onde a ciência é abordada em seus diversos assuntos e desdobramentos. Esse formato de se noticiar ciência começou a ser mais comum em jornais nacionais e regionais, especialmente nos últimos trinta anos (MOREIRA; MASSARANI, 2002).

Segundo Moura (2003), a divulgação científica é um processo que utiliza a mídia 
como meio de comunicação, e que precisa do diálogo entre a imprensa, a comunidade científica e a sociedade civil para se ter sucesso. Sendo assim, é através desse diálogo que a difusão da ciência poderá ser feita e, com isso, a informação científica poderá fazer parte do cotidiano do cidadão de uma forma consciente.

\section{UTILIZAÇÃO DO JORNAL E POSSIBILIDADES PARA FINS DIDÁTICO- PEDAGÓGICOS}

O uso do jornal como recurso didático no processo de ensino e aprendizagem data da metade do século XX (RODRIGUES, 2006). Sua utilização conduz o aluno a pensar e agir por meio da leitura e interpretação de textos de cunho formal, além disso, permite a inserção dessa prática a novos leitores.

Para alguns autores, como Cavalcanti (1999), Faria (2006) e Gadotti (2007), a utilização do jornal como uma ferramenta pedagógica auxilia na transformação dos estudantes, de meros expectadores para cidadãos formadores de opinião.

Segundo Souza (2008) o uso de jornais como ferramenta didático-pedagógica tem crescido, em especial por tal ferramenta possuir riqueza de informações e por resgatar o prazer pela leitura.

Ao propor atividades diversas, o jornal permite estimular os acadêmicos a uma constituição do senso crítico, relacionando ideias do senso comum com conceitos científicos. Desta forma, desenvolve a autonomia do estudante e promove a ampliação do conhecimento de forma crítica e livre, criando situações colaborativas favoráveis, propiciando aos acadêmicos múltiplas possibilidades de atuação (MORIN, 2001).

A leitura e a produção de textos são mecanismos importantes na vida dos estudantes. As práticas de leitura e da produção textual de qualidade permitem uma adequada apreensão da realidade e conduz a uma participação social mais concreta, favorecendo a compreensão crítica e consciente do real.

Para Ferreira (2008) citado por Anhussi (2009, p.23) o texto jornalístico muitas vezes é muito mais bem sucedido do que o livro didático, além de que os textos não escolares têm elevada participação na formação do cidadão. Estudos mostram que o uso do jornal acompanhado do livro didático resulta na "percepção da necessidade de se colocar o aluno em contato com a realidade cotidiana, que os livros registram somente depois de um decurso de tempo" (TONINI, 2006, p.1).

Deste modo, ao fazer o uso do jornal é possível trabalhar diversos conteúdos escolares, com o uso da leitura, interpretação e produção de textos, promovendo a interdisciplinaridade, melhor visualização de como esse aluno está inserido no meio social e permitindo a reflexão de variados temas.

\section{UM POUCO SOBRE O JORNAL MOMENTO QUÍMICO}

O jornal intitulado "Momento Químico" consiste em um veículo informativo que circula mensalmente em um campus da Universidade do Estado de Santa Catarina, principalmente entre alunos e professores do curso de licenciatura em Química. As edições do jornal são afixadas em ambientes estratégicos na universidade, nos quais alunos e professores podem ler e conversar sobre as matérias publicadas neste jornal mural. Além disso, as edições são impressas e entregues individualmente para alunos e professores do campus e, também, para alunos de algumas escolas de educação básica participantes de projetos vinculados à Universidade. O jornal também conta com um blog em que as edições são publicadas online

(https://jornalmomentoquimico.wordpress.com /). Neste aspecto, a divulgação do jornal ultrapassa a fronteira do curso de licenciatura em Química da instituição, permitindo que alunos de outros cursos, outras instituições, bem como os mais diversos públicos, tenham acesso aos assuntos debatidos em cada edição.

A equipe do jornal Momento Químico é composta atualmente por 6 alunos do curso de licenciatura em Química (1 bolsista e 5 voluntários) e dois docentes do Departamento de Química (1 coordenador e 1 participante). Além disso, conta com a ajuda de professores de língua portuguesa que revisam os textos antes de serem publicados. Todos os textos são produzidos pelos alunos integrantes da equipe do jornal, sob a supervisão dos professores responsáveis.

A organização das matérias e seções do jornal é realizada a partir de uma temática 
escolhida pelos integrantes do projeto. A partir desta temática, que normalmente possui um apelo CTS (Ciência, Tecnologia e Sociedade), são definidas as seções que serão abordadas naquela edição, dentre as quais: artigo ou matéria principal, artigo ou matéria secundária, artigo ou matéria histórica, entrevistas com professores e alunos, curiosidades e atualidades, calendário e entretenimento. A

Figura 1 apresenta resumidamente algumas das principais edições de 2016.

Figura 1 - Algumas das edições do jornal Momento Químico

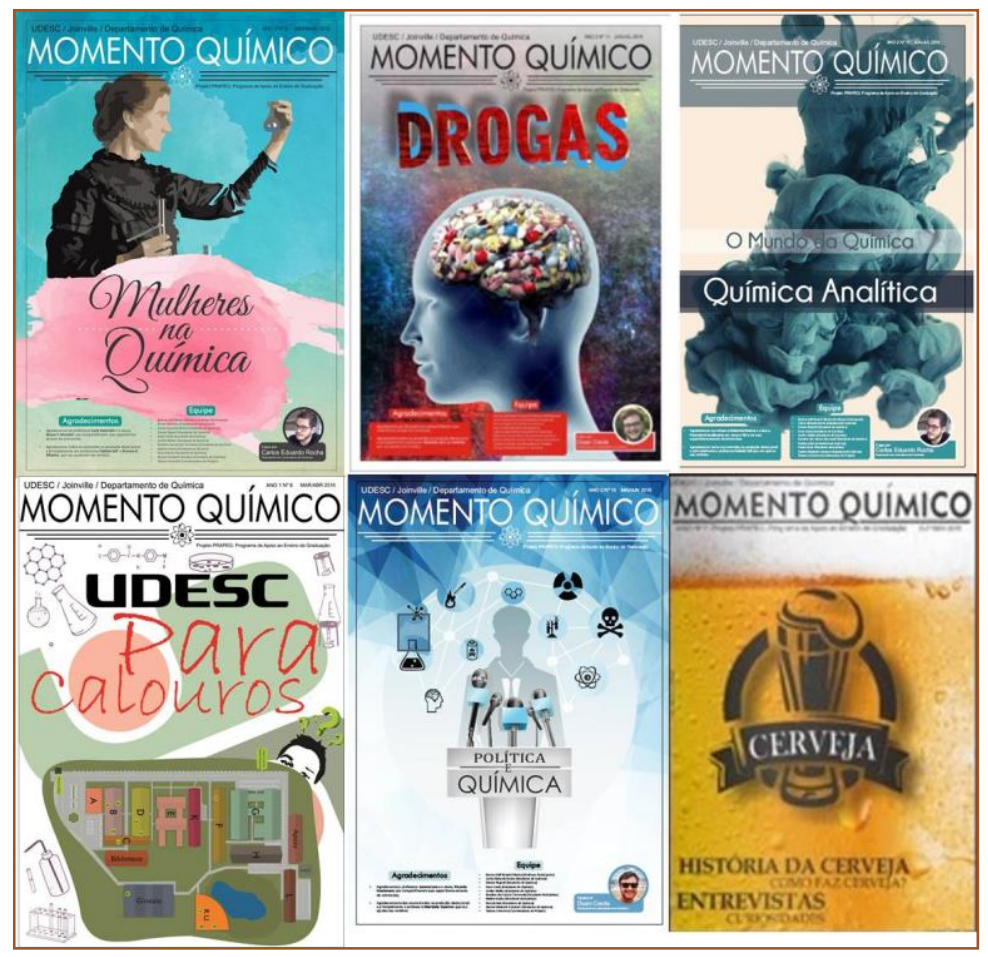

\section{PERCURSO METODOLÓGICO}

O presente trabalho buscou investigar a aceitação e os desdobramentos da circulação do jornal Momento Químico entre os estudantes do curso de licenciatura em Química da Universidade do Estado de Santa Catarina. Além disso, buscou-se verificar para qual finalidade cada estudante lê o jornal, em especial para conhecer suas motivações e interesses.

Para tanto, os estudantes participaram de uma pesquisa presencial, que consistiu em responder um questionário composto de perguntas discursivas e objetivas, permitindo inferir alguns aspectos importantes que serão discutidos ao longo deste trabalho.

Participaram desta pesquisa um total de 107 alunos da graduação, distribuídos entre a $1^{\underline{a}} \mathrm{e}$ 8 a fase do curso de licenciatura em Química ( $1^{\underline{a}}$ fase -12 alunos, $2^{\underline{a}}$ fase -40 alunos, $3^{\underline{a}}$ fase -19 alunos, $4^{\mathrm{a}}$ fase -15 alunos, $5^{\mathrm{a}}$ fase 6 alunos, $6^{\mathrm{a}}$ fase -10 alunos, $7^{\mathrm{a}}$ fase -4 alunos, 8 $8^{\text {a }}$ fase -1 aluno). No entanto, este número sofreu algumas variações, considerando que alguns alunos deixaram de responder algumas das questões propostas no questionário. Neste sentido, foram selecionadas algumas questões para serem discutidas neste trabalho e em cada uma delas será apresentado 0 total de respondentes para que a análise possa se basear em um quantitativo adequado.

A análise das respostas ao questionário foi realizada a partir da análise de conteúdo proposta por Bardin (1977), de modo que, após todos os estudantes terem respondido a presente pesquisa, foi realizada uma préanálise, em que todos os registros escritos individualmente pelos estudantes foram organizados de acordo com cada questão proposta e em seguida realizou-se uma leitura flutuante destes textos a fim de melhor explorar o material. Na exploração do material cada resposta recebeu um ou mais indicador (código) com o intuito de agrupar as respostas e categorizá-las posteriormente. Por fim, considerando a quantidade de vezes que cada indicador incidiu, foram destacadas as categorias para discutir o que emergiu do 
material. Todo este processo foi realizado separadamente por questão e será discutido neste trabalho também desta forma. Para isso, foram escolhidas apenas algumas questões, das quais se obteve um material mais significativo para refletir a partir das duas categorias discutidas a seguir.

\section{ALGUNS RESULTADOS}

5.1 O JORNAL MOMENTO QUÍMICO SOB A OTICA DE SEUS LEITORES: UMA AVALIAÇÃO ACERCA DAS EDIÇÕES

Esta categoria emergiu das respostas dos alunos as questões 2, 4, 5 e 7, cuja Figura 2, Figura 3,

Figura 4 e Figura 5 apresentam os resultados quantitativos para estas questões.

Figura 2 - Quantitativo das respostas dos alunos conforme a finalidade de leitura para o jornal

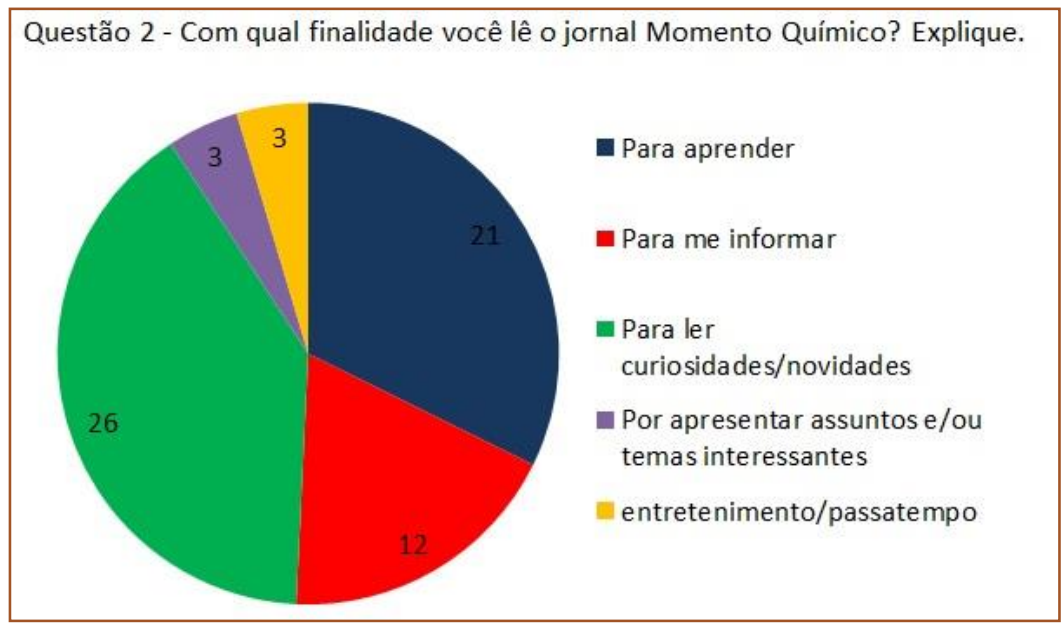

Analisando as respostas dos alunos para a Questão 2 (Figura 2) é possível verificar que a maioria deles lê o jornal para saber sobre as curiosidades e novidades divulgadas por cada uma das edições do jornal (26) e também para aprender sobre os assuntos e temas abordados nas matérias publicadas (21). Dentre as respostas, destacam-se as justificativas "Para saber/aprender sobre os assuntos tratados, que em algumas vezes eu não tinha conhecimento", "Para aprender mais sobre o assunto abordado e gerar 'links' com conteúdos que já domino" e "Por curiosidade, a fim de buscar maior conhecimento entorno do conteúdo que o jornal propõe. Busco ler as histórias e opiniões dos alunos e professores aqui da universidade".

Além disso, alguns alunos afirmaram que leem o jornal com o intuito de se informar (12), em especial "Para conhecer mais sobre a Química e ter informações sobre nosso curso" e "Para saber o que está acontecendo no curso, aprender coisas novas e acompanhar a trajetória dos professores".

Observa-se que os leitores buscam no jornal
Momento Químico uma fonte para se informar, aprender e saber mais sobre os temas científicos e os assuntos locais abordados em cada edição. Neste sentido, o jornal tem conseguido despertar em seus leitores a expectativa de esperar cada edição, assim como, promover o hábito da leitura entre os estudantes do curso de licenciatura em Química.

Despertar o interesse dos leitores é um ponto fundamental na divulgação científica e contribui diretamente na construção de conhecimentos em ambientes extra sala de aula. No ensino de ciências o olhar da sedução pode estar associado ao papel desempenhado pela divulgação, de revelar o interesse por temas científicos, de incentivar novas leituras, de gerar comportamentos e ações nos leitores (curiosidade, emoção etc.), de atrai-lo e inseri-lo no mundo da ciência etc. (SALÉM \& KAWAMURA, 1996; SILVA, 2001, ALMEIDA, 1998).

$\mathrm{Na}$ Questão 4 (Figura 3), a partir da pontuação atribuída a cada seção do jornal (soma das notas atribuídas para cada seção), verificou-se o quanto os leitores estão 
interessados em cada uma delas. Desta forma, quanto maior a pontuação, menor seria

o interesse do aluno por aquela seção.

Figura 3 - Pontuação para cada seção do jornal conforme o grau de interesse dos alunos

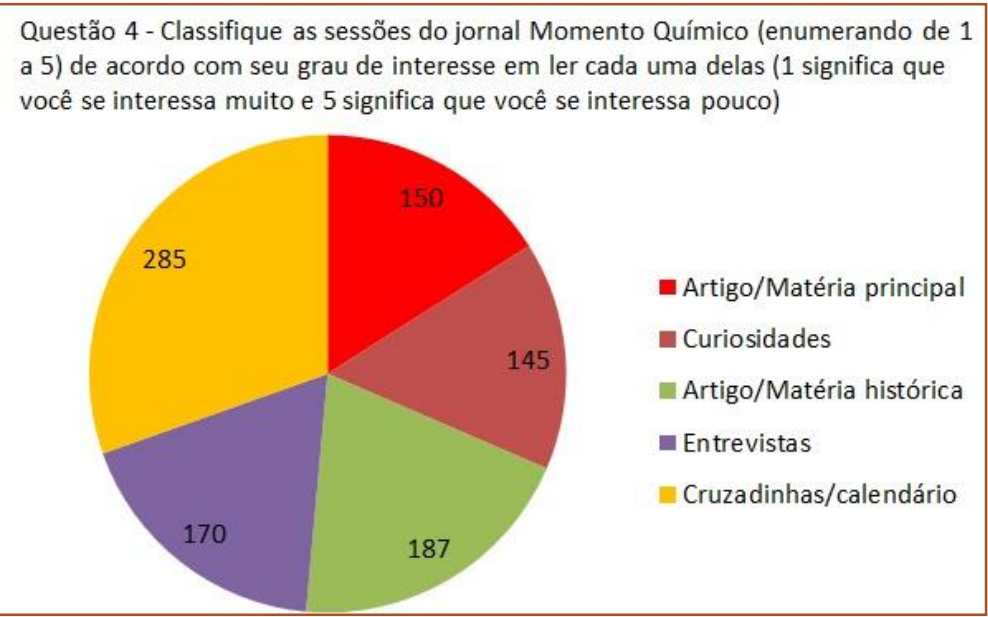

Verificou-se que a ordem de interesse dos alunos para as seções do jornal é: 1 Curiosidades, 2 - Artigo/Matéria principal, 3 Entrevistas, 4 - Artigo/Matéria histórica, 5 Cruzadinhas/calendário.

Este resultado revela qual seção do jornal é a que mais interessa aos alunos, ou seja, aquela que provavelmente será lida tão logo o aluno recebe o jornal. Nesta perspectiva, denota-se que as temáticas escolhidas para cada edição do jornal possuem fundamental importância, uma vez que a partir delas é que são escritas estas seções que mais interessam os leitores: as matérias principais e também as curiosidades (que permeiam ou não os textos das outras seções do jornal).

De acordo com os Parâmetros Curriculares Nacionais para o Ensino Médio (BRASIL,
2002) o uso desses textos científicos possibilita o contato do estudante com informações atualizadas sobre ciência e tecnologia, tornando o conhecimento científico mais significativo para eles, e formando-os para a ação social responsável e consciente.

Além disso, a Figura 3 também permite constatar que há um interesse relativamente grande dos alunos em conhecer mais sobre a trajetória pessoal e acadêmica dos professores e alunos do departamento.

A Figura 4 revela que os leitores na maioria das vezes (38) não tinham conhecimento sobre os assuntos abordados nas matérias do jornal e consideraram-nas interessantes, ou então tinham algum conhecimento sobre o assunto e o consideraram interessante (31).

Figura 4 - Quantitativo do julgamento dos alunos acerca dos artigos e matérias do jornal

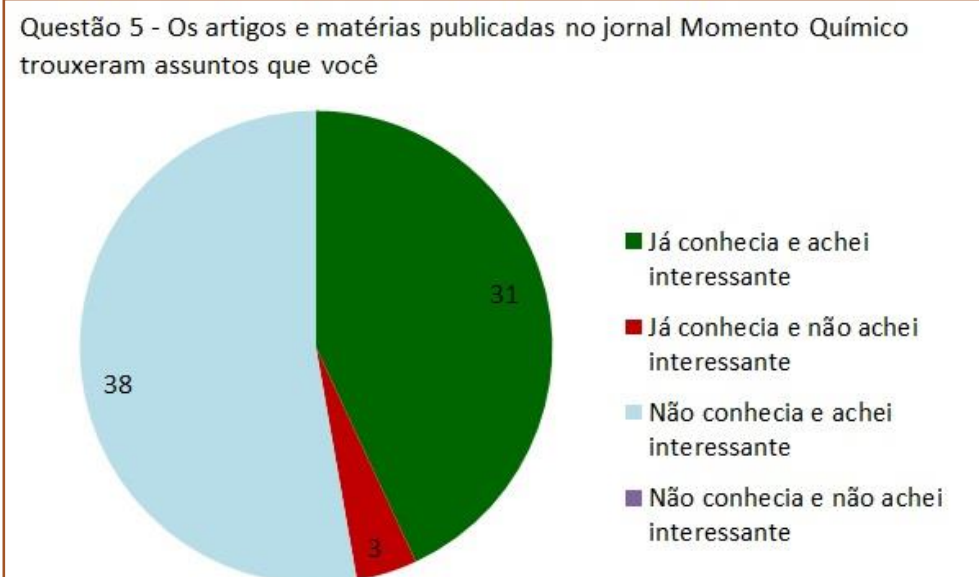


É muito importante que os textos produzidos em um jornal de divulgação científica sejam acessíveis aos leitores, independentemente de seu grau de leitura e instrução.

Conforme Oliveira (2002, p. 13),

[...] o acesso às informações sobre C\&T é fundamental para o exercício pleno da cidadania e, portanto, para o estabelecimento de uma democracia participativa, na qual grande parte da população tenha condições de influir, com conhecimento, em decisões e ações políticas ligadas a C\&T. Entendemos que a formação de uma cultura científica [...] não é processo simples [...]. No entanto, o acesso às informações sobre C\&T como um dos mecanismos que pode contribuir de maneira efetiva para a formação de uma cultura científica deve ser facilitado ao grande público carente delas.

Neste sentido, a Figura 5 revela que a maior parte dos leitores considera os textos do jornal Momento Químico como de fácil compreensão, com pouca formalidade, com conteúdos com quantidade de fontes suficientes e quantidade adequada de conteúdos científicos.

Figura 5 - Quantitativo da classificação dos alunos acerca da escrita dos textos do jornal

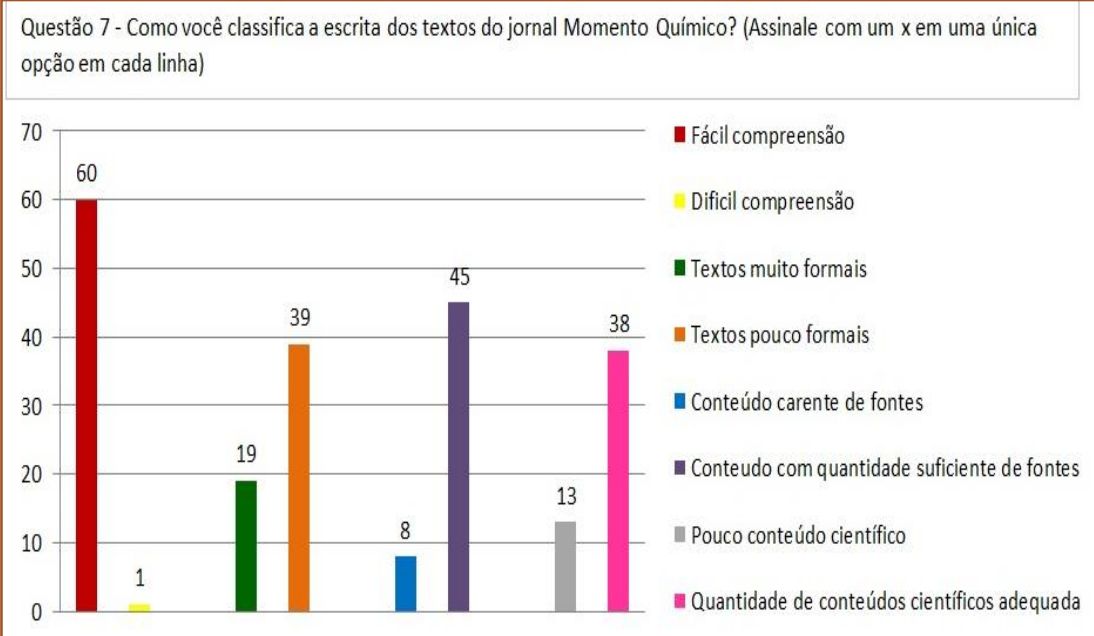

Logo, é possível inferir que o nível de compreensão, leitura e interpretação dos leitores é equiparável a linguagem apresentada pelos textos, bem como sua estruturação e apresentação iconográfica no jornal, permitindo que os leitores acompanhem as matérias e avaliem positivamente os textos publicados nas diferentes edições do jornal.

\subsection{OS DESDOBRAMENTOS DO JORNAL MOMENTO QUÍMICO ENTRE SEUS LEITORES: ALGUMAS PERSPECTIVAS}

Esta categoria emergiu das respostas dos alunos as questões 6, 8, 9 e 10, cuja Figura 6, Figura 7, Figura 8 e Figura 9 apresentam os resultados quantitativos das respostas.

Analisando as respostas para a Questão 6 (Figura 6) observa-se que a quantidade de alunos que conversam com seus colegas sobre os artigos e matérias publicadas no jornal é praticamente equivalente a quantidade de alunos que não possuem este hábito. Dentre as justificativas apresentadas pelos alunos a esta questão, destaca-se que "Sim, algumas matérias relatam coisas do cotidiano e ou matérias relacionadas ao que estamos aprendendo em sala", "Sim, sempre levo o jornal para casa, onde meus pais e meus avós leem e acham interessante os temas abordados, quando eles tem dúvidas, eu explico", "Geralmente não, pois costumo ler o jornal sozinho em casa". 
Figura 6 - Quantitativo das respostas dos alunos para a Questão 6

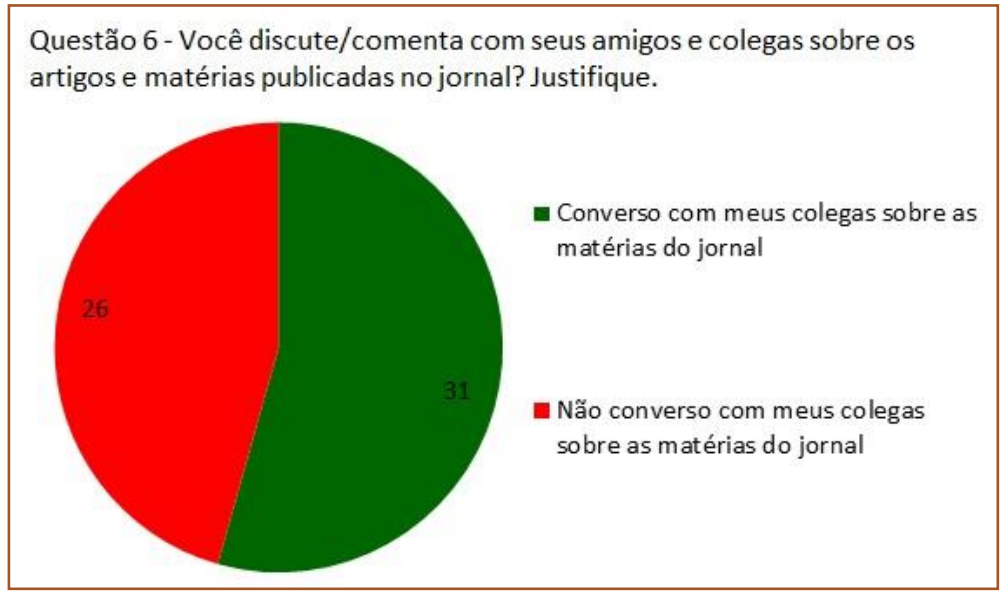

Esperava-se que as edições do jornal Momento Químico despertassem mais discussões entre os alunos, de modo que os aspectos abordados nos textos fossem mais bem compreendidos em conversas informais, ou até mesmo levados para os ambientes formais de aprendizagem como as disciplinas do curso de licenciatura em Química, por exemplo. Entretanto, este resultado não pode prever acerca do potencial de discussão que as temáticas apresentadas nos artigos e matérias do jornal possuem.

Complementando a discussão dos resultados apresentados pela Figura 6, é possível verificar se os leitores do jornal constroem conhecimentos ao acessar os textos apresentados nas diversas edições do jornal Momento Químico. Nesta perspectiva, observa-se pela Figura 7, que 34 alunos afirmam ter aprendido sobre algum assunto nos textos do jornal, enquanto que 30 alunos dizem nunca terem aprendido nada novo a partir da leitura dos textos.

Dentre as justificativas mais interessantes, destacam-se "Sim, que me chamou atenção foi sobre equilíbrio químico", "Sim, questões químicas em torno das drogas, da participação essencial das mulheres na construção dos conhecimentos Químicos", "Nunca aprendi, mas passei a conhecer fatos e dados que antes desconhecia".

Figura 7 - Quantitativo das respostas dos alunos para a Questão 8

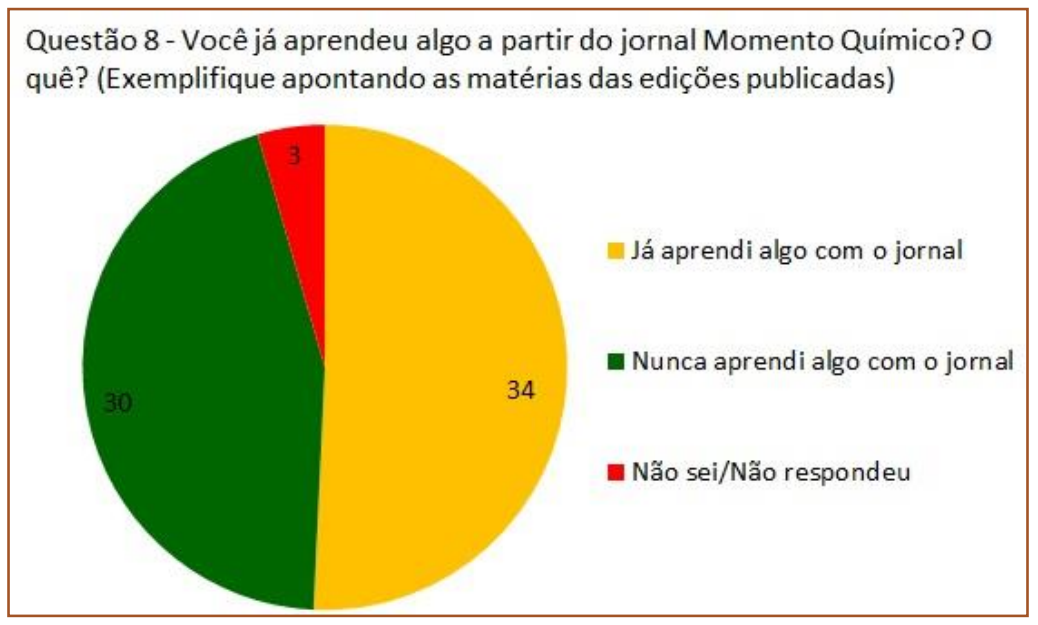

Vale salientar que, embora o jornal possa proporcionar situações de aprendizagem ao leitor em ambientes não formais, o papel do professor mediador não é dispensável na promoção dos aprendizados abordados nos textos. Assim, se o professor utilizar o jornal como um recurso didático para discutir assuntos inerentes a ciência e para construir conhecimentos científicos, certamente obterá um resultado mais satisfatório do que quando o leitor realiza tais procedimentos sozinho. 
Desta forma, as Questão 9 e a Questão 10 permitem verificar se os alunos (futuros professores de Química) foram ensinados durante a graduação sobre como utilizar o jornal como um recurso didático e se veem a possibilidade de usar o jornal nas aulas no ensino médio.

Figura 8 - Quantitativo das respostas dos alunos para a Questão 9

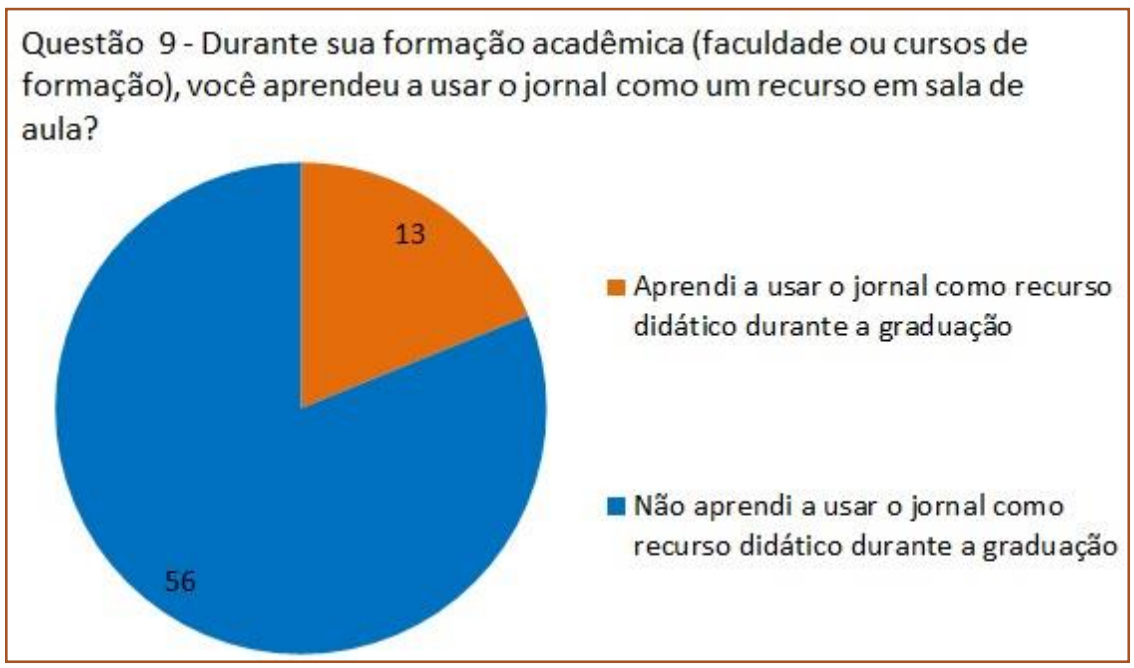

Figura 9 - Quantitativo das respostas dos alunos para a Questão 10

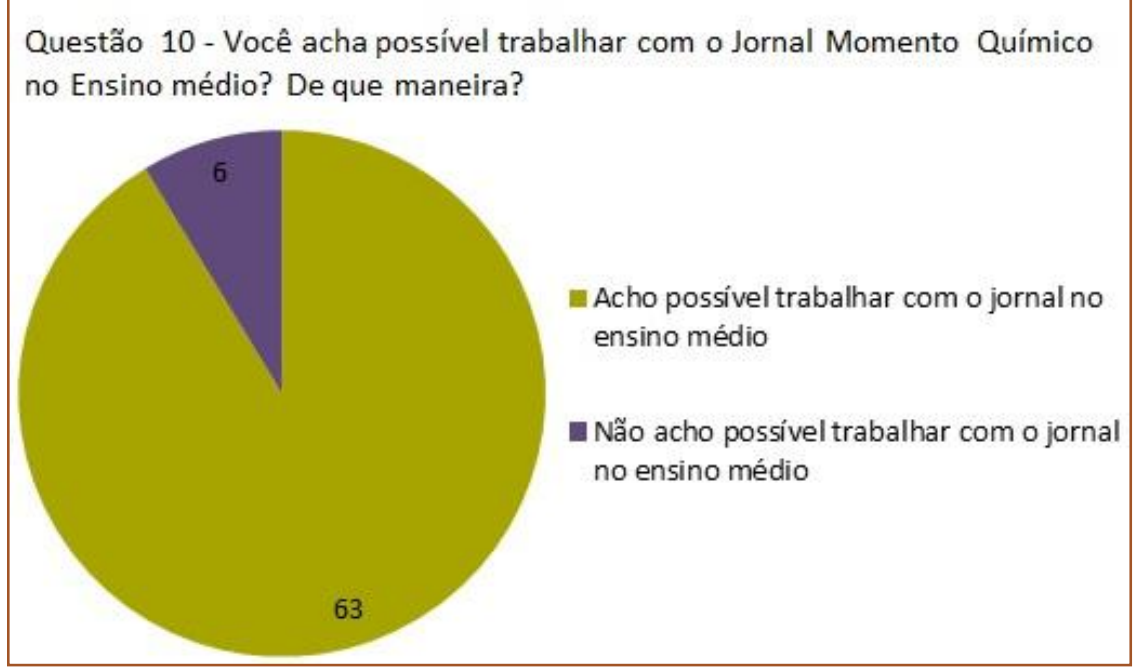

A Figura 8 e Figura 9 revelam que a maior parte dos alunos não aprendeu sobre como utilizar o jornal enquanto recurso didático nas aulas de Química (56), mas acham possível utilizá-lo nas aulas do ensino médio (63).

Dentre as justificativas, destacaram-se "Acho que despertaria o interesse dos alunos" e "Não, para mim os alunos não levariam a sério".

O pequeno número de alunos que aprendeu a utilizar o jornal como um recurso didático reflete aqueles que estão cursando as fases finais do curso, uma vez que, com a vivência nos estágios supervisionados e as disciplinas mais voltadas à prática de ensino, os futuros professores conseguem explorar melhor maneiras criativas para se trabalhar conceitos científicos nas aulas no ensino médio.

Neste sentido, é fundamental que os professores formadores incorporem as suas práticas o uso de estratégias diferenciadas como a de utilizar um jornal de divulgação científica para promover o diálogo e a construção de conhecimentos, a fim de 
instrumentalizar o licenciando para suas práticas futuras.

\section{CONSIDERAÇÕES FINAIS}

A partir da realização da presente pesquisa foi possível constatar que o jornal Momento Químico apresenta boa aceitação entre os alunos do curso de licenciatura em Química, pois vários estudantes consideram interessantes as matérias e artigos publicados nas edições do jornal, independente se conhecem ou não os assuntos trazidos pelos textos. Neste sentido, os leitores apresentam uma preferência pelas curiosidades, pela seção com os artigos/matérias principais e a seção de entrevistas. Além disso, uma pequena quantidade de leitores julgou os textos como de difícil compreensão, fato que denota que a linguagem dos textos está acessível, auxiliando diretamente na transposição de assuntos do meio científico.

Cabe salientar também que algumas das reflexões propostas no questionário permitem inferir boa aceitação dos leitores em relação ao jornal como, por exemplo, nas justificativas para a possibilidade de trabalhar com o jornal no ensino médio.

\section{REFERÊNCIAS}

[1]Anhussi, E. C. O Uso do jornal em sala de aula: Sua importância e concepções de professores. Dissertação - Faculdade de Ciências e Tecnologia, UNESP/FCT.São Paulo, 2009.

[2]Bardin, L. Análise de conteúdo. Lisboa: Edições 70, 1977

[3]Bastos, H. F. B. N. Disciplinaridade: multi, inter e trans. Revista Construir Notícias. n.14, ano 3, p. 4041, 2004.

[4]Brasil. Mec. Secretaria de Educação Média e Tecnológica. PCNs+ Ensino Médio: orientações educacionais complementares aos Parâmetros Curriculares Nacionais. Brasília, 2002. 144 p

[5]Brasil. Secretaria de Educação Fundamental. Parâmetros Curriculares Nacionais: Meio Ambiente. Brasília: MEC/SEF, 1998.

[6]Cavalcanti, J. O jornal como proposta pedagógica. São Paulo. Paulus, 1999.

[7]Falk, J. \& Dierking, L. D. Lessons Without Limit: how free-choice learning is

[8]transforming education. Altamira Press, California, 2002.

[9]Faria, M. A. Como usar o jornal na sala de aula. São Paulo. Contexto, 2006.

[10] Favero, O. Educação não-formal: contextos, percursos e sujeitos. Educ. Soc. [online]. v.28, n.99, pp.614-617, 2007.

[11] Gadotti, M. O jornal na escola e a formação de leitores. Brasília. Liber Livro Editora,
Ademais foi possível verificar algumas das implicações da circulação do jornal entre seus leitores, em especial constatando que vários estudantes conversam com os colegas a respeito das matérias e que também aprenderam sobre diversos assuntos a partir dos textos publicados no jornal.

Por fim, observou-se que os estudantes leem o jornal Momento Químico principalmente para aprender, se informar e também saber sobre curiosidades/novidades acerca da Química ou sobre a universidade.

Portanto, ressalta-se que o jornal tem conseguido cumprir seu papel na divulgação científica, ao trazer temas relevantes que contenham conceitos discutidos na área das ciências e que promovem maior interesse dos estudantes pela leitura científica, bem como permitem a construção de conhecimentos em ambientes que ultrapassam as fronteiras da sala de aula. Entretanto, essa ainda é uma iniciativa pontual e, por isso, são necessárias outras iniciativas que popularizem a ciência, a tornem mais acessível aos indivíduos nas diversas cidades e regiões do Brasil e que que analisem sistematicamente a eficácia de tais iniciativas no cenário da educação em ciências.

2007.GOHN, M. G. Educação não-formal, participação da sociedade civil e estruturas colegiadas nas escolas. Ensaio: aval. pol. públ. Educ., Rio de Janeiro, v.14, n.50, p. 27-38, jan./mar.2006.

[12] Jenkins, E. W. School science, citizenship and the public understanding of science.

[13] International Journal of Science Education, v.21, n.7, p.703-710, 1999

[14] Lopes, J.; Silva, H. S. A aprendizagem cooperativa na sala de aula: um guia prático para o professor. Lisboa: Lidel, 2009

[15] Moreira, I. C.; MASSARANI, L. Aspectos históricos da divulgação científica no brasil. Ciência e público, p. 43-64, 2002.

[16] Morin, e. A Cabeça bem-feita: repensar a reforma, reformar o pensamento. Rio de Janeiro, Bertrand do Brasil, 2001.

[17] Moura, D. O. A popularização da informação científica na Sociedade de Risco: em busca do diálogo. Comunicação e Espaço Público, Brasília, v. 6, n. 1 e 2, p. 52-64, 2003.

[18] Oliveira, F. de. Jornalismo científico. 2. ed. São Paulo: Contexto, 2002

[19] Rodrigues, M. O. A integração do recursojornal na prática pedagógica do professor: estudo de uma proposta de formação continuada. Dissertação. Curitiba/PR. 2006.

[20] Salém, S. \& KAWAMURA, M.R.D. O texto de divulgação e o texto didático: conhecimentos 
diferentes? In: Atas do $V$ Encontro de Pesquisadores em Ensino de Física - EPEF. Águas de Lindóia, SP, 1996.

[21] Santos, M.E.V.M. A cidadania na "voz" dos manuais escolares. Lisboa: Livros Horizonte, 2001.

[22] Silva, H. C. O que é divulgação científica? Ciência \& ensino, São Paulo, v. 1, n. 1, p. 53-59, dez. 2006.

[23] Souza, M. D. Práticas de trabalho com jornal impresso: como acontece em sala de aula?. In: IV Seminário Nacional "O Professor e a leitura do Jornal". Campina/SP, 2008.

[24] Tonini, I. M., Alves, A. L. F. O jornal em sala de aula como recurso pedagógico no suporte da educação: a experiência do município de horizonte - ce. In: 58 ${ }^{\underline{a}}$ Reunião Anual da SBPC . Florianópolis - SC, 2006. 


\section{Capítulo 8}

\section{O EXPERIMENTO DE RUTHERFORD EM LIVROS DIDATICOS BRASILEIROS: REPRODUÇÃO DE ESTILOS DE PENSAMENTO E TRANSPOSIÇÃO DIDATICA}

\section{Ehrick Eduardo Martins Melzer}

Resumo: O presente capítulo traz uma análise do saber sobre o experimento de Rutherford em livros didáticos de química destinados ao ensino superior e a educação básica (ensino médio). Ao todo foram analisados 14 livros destinados ao ensino superior e 26 livros destinados ao ensino médio. Esses dados contemplam a síntese de três artigos apresentados em eventos científicos no anos de 2015, 2016 e 2017 (MELZER, 2015, 2016 e 2017). A ferramenta teórica usada para as análise partiu da confluência entre o aporte teórico de Chevallard (1991) e Fleck (2010). Os livros foram analisados usando a técnica de análise de conteúdo de Bardin (2010). Dos dados colhidos pode-se depreender que os livros didáticos brasileiros destinados ao ensino médio reproduziram estilos de pensamento de transposição didática baseados em livros importados destinados ao ensino superior. 


\section{INTRODUÇÃO}

Este capítulo pode ser compreendido como uma síntese de três trabalhos construídos ao longo de 2015, 2016 e 2017, traçando uma trajetória de pesquisa em torno do experimento de Rutherford. Em todos os trabalhos parti de questão central: Quais estilos de pensamento sobre a transposição didática do experimento de Rutherford aparecem nos livros didáticos de química para o ensino superior? (MELZER, 2017, p. 2).

A partir desta questão, inicialmente, buscouse desenvolver uma relação teórica entre a Transposição Didática de Yves Chevallard com o Tráfego de Pensamentos de Ludwik Fleck. Após este primeiro estudo o modelo gerado foi submetido a um primeiro teste que gerou um artigo apresentado no Encontro Nacional de Ensino de Química (ENEQ) e, posteriormente, resultou em uma outra análise de livros da educação superior que foi apresentado no Encontro Nacional de Pesquisa em Ensino de Ciências (ENPEC).

Este capítulo por sua vez tem como objetivo juntar a trajetória de pesquisa, buscando elucidar um modelo de análise de livros didáticos no que toca ao conteúdo do experimento de Rutherford. Busco responder a seguinte pergunta: No Brasil o saber sobre o experimento de Rutherford foi uma inovação ou uma reprodução baseada em uma transposição do saber sábio?

Para responder a esta pergunta busco organizar este capítulo em 4 partes. A primeira destinada a discussão do modelo teórico que vem sendo construído ao longo de 2015, 2016 e 2017, fazendo aproximações da Transposição Didática de Yves Chevallard com o Tráfego de Pensamento de Ludwik Fleck. $\quad \mathrm{Na}$ segunda parte busca-se desenvolver a construção histórica do Saber Sábio (Ciência de Referencia) sobre o experimento de Rutherford, utilizando artigos como fontes primárias. $\mathrm{Na}$ terceira parte apresenta-se os dados da pesquisa, buscando compreender como o saber experimento de Rutherford constituiu-se nos livros didáticos de química brasileiros. E por final, as considerações finais, buscando responder a questão de pesquisa inicial deste capítulo.

\section{CHEVALLARD E FLECK: RELAÇÕES ENTRE OS ESTILOS DE PENSAMENTO COM A TRANSPOSIÇÃO DIDÁTICA}

Em primeiro lugar temos de compreender que Chevallard e Fleck viveram em épocas diferentes, locais diferentes e buscavam em suas pesquisas responder a questões diferentes. Porém, Ludwik Fleck em sua obra "a gênese e desenvolvimento de um fato científico" elucidou um modelo de análise do saber denominado de Tráfego de Pensamentos.

Para Fleck (2010) uma teoria percorre um caminho epistemológico passando por fases de desenvolvimento, sendo que este caminho tem profunda relação com fatos históricos, sociais, econômicos e políticos que podem retardar ou impulsionar o desenvolvimento científico. Nesse sentido podemos organizar este pensamento sobre a construção do conhecimento científico no seguinte diagrama:

Figura 1: Sistematização da teoria proposta por Fleck (2010).

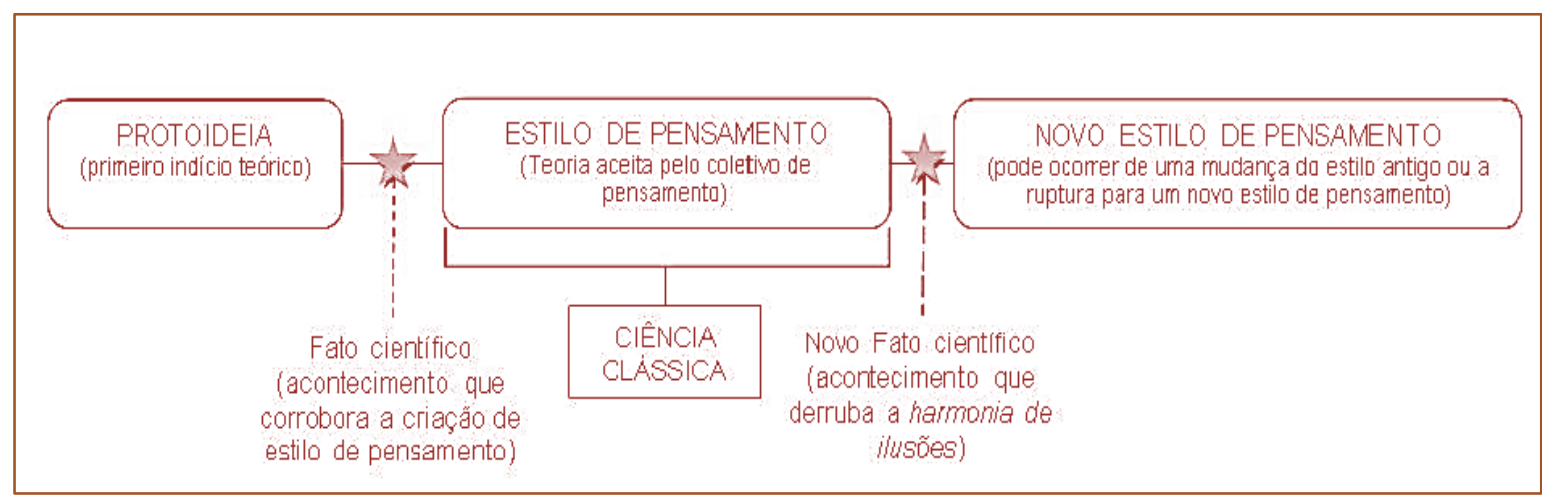

As protoideias na cosmovisão de Fleck (2010) são sistema de crenças e ideias que não tem uma base científica, portanto, não são considerados ciência. O estilo de pensamento pode ser compreendido como uma protoideia sistematizada e aceita por um coletivo de 
pesquisadores como sendo científica. A etapa limítrofe de mudança de uma protoideia para estilo de pensamento é o fato. O fato é necessariamente um dado, acontecimento, resultado experimental ou uma fonte que comprove e solidifique um sistema de ideias conformando um estilo de pensamento.

Fleck (2010) parte da perspectiva que quando um fato surge e dá legitimidade a um sistema de ideias formando um estilo de pensamento. No momento em que este estilo de pensamento encontra seu auge (foi intensamente estudado) o sistema de pensamento entra em um período de ciência clássica.

Dentro da etapa de ciência clássica há o que pode-se compreender como harmonia de ilusões. Para Fleck (2010) ela cega o pesquisador para a possibilidade de pensar diferente. Ou seja, a harmonia de ilusões é responsável pelo imobilismo acadêmico e pela acomodação da comunidade científica, tudo que é diferente é rejeitado. Outra característica da construção teórica de Fleck (2010) é a possibilidade de ruptura de estilos de pensamento (descontinuidade) ou como a transformação do estilo de pensamento (continuidade).

O Coletivo de Pensamento é que define e estrutura os Estilos de Pensamento. É formado por duas estruturas: exotérica e esotérica. Dentro do Coletivo de Pensamento a estrutura exotérica, mais periférica, recebe os Estilos de Pensamento pensados e estruturados pela estrutura mais interna (esotérica)

No que se refere ao Tráfego Intercoletivo e Intracoletivo de pensamentos, Fleck argumenta serem as comunicações externas e internas de um determinado Coletivo de Pensamento. Além desse Tráfego de Pensamentos Fleck (2010) define que há categorias de ciências que permeiam toda a nossa sociedade, são elas: Ciência Especializada, Ciência Popular, Ciência dos Livros Didáticos.

A Ciência Especializada é formada por duas subcategorias de ciência: Ciência dos Manuais e Ciência dos Periódicos. A primeira (Ciência dos Manuais) é apresentada para pesquisadores em formação de nível superior, quando, segundo o autor, o estudante de graduação é iniciado na profissão, são estudos, textos e livros voltados para a formação inicial do profissional. Já a segunda (Ciência dos Periódicos) é voltada para a comunicação dentro do círculo esotérico do Coletivo de Pensamento. Compõe os periódicos no quais os pesquisadores pertencentes ao coletivo publicam os resultados primeiros de suas pesquisas e lançam questionamento ou aprofundamentos em torno do Estilo de Pensamento, trabalhos que estão no bojo da pesquisa e do desenvolvimento científico.

A Ciência Popular na cosmovisão de Fleck (2010) é a ciência das camadas mais esotéricas da sociedade, ou seja, é a ciência do povo. É a ciência como é comunidade para a população em geral e que, geralmente, está cheia de incoerências e equívocos conceituais ou está desatualizada em relação à Ciência Especializada. Uma característica marcante para Fleck (2010) é que essa ciência influencia toda a sociedade desde o mais leigo até o cientista que está no bojo da produção científica.

E a Ciência dos Livros Didáticos pode ser compreendida como a forma que a ciência é divulgada na instituição Escolar. Para Fleck (2010) é a ciência responsável pela iniciação científica do estudante. Porém, lembra também que essa categoria de ciência é relativamente autônoma no sentido de produzir um sentido próprio de ciência e de atividade científica que pode entrar em conflito com a Ciência Especializada.

Já a Transposição Didática é uma teoria de vigilância epistemológica dos saberes. Para Chevallard (1991) o processo baseia-se na passagem do saber sábio para saber a ensinar e que, consequentemente, se transforma em saber ensinado. O saber sábio é aquele formado a partir da pesquisa acadêmica de ponta quando o pesquisador de posse dos dados de pesquisa escreve e publica um artigo científico. Já o saber a ensinar, produto da transposição do saber sábio, é aquele saber que compõe os texto de ensino e os livros didáticos. Esse saber é gerado por uma superestrutura denominada de noosfera. A noosfera pode ser compreendida como a esfera que pensa e desenvolve a Transposição Didática, é formada por grupo que politicamente e socialmente, debatem e desenvolvem os recortes para conformar o saber a ensinar.

Outra categorização de Chevallard (1991) está na separação etapas de Transposição Didática Externa e Interna. A etapa Externa é formada pela passagem de saber sábio para - saber a ensinar pela noosfera. A etapa 
Interna que ocorre dentro da escola, na sala de aula, é formada na passagem de saber a ensinar para saber ensinado. Assim o processo de Transposição Didática pode ser sistematizado da seguinte forma:

Figura 2: Sistematização da teoria proposta por Chevallard (1991).

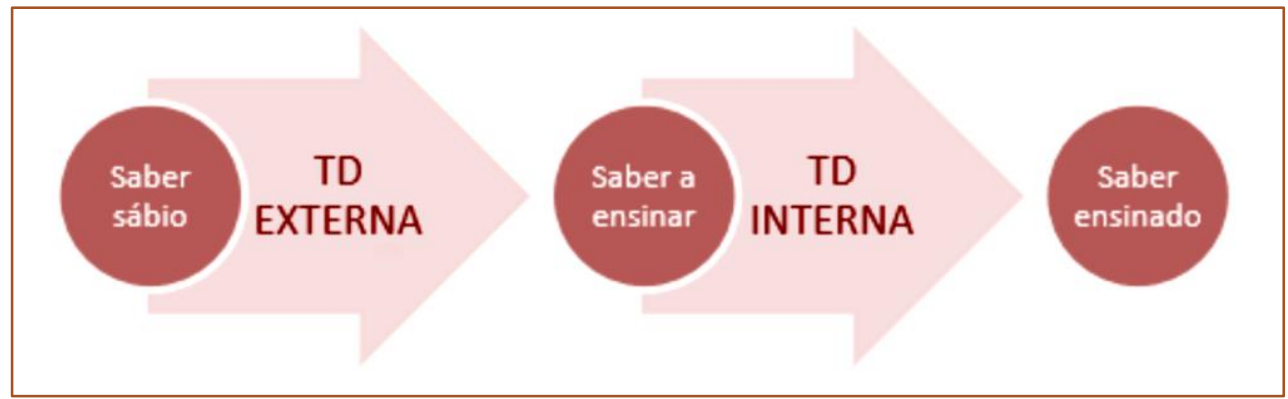

A partir dessa sistematização Chevallard (1991) avalia que existem, para o saber matemático, 10 elementos responsáveis para a formação dos saberes, são eles: despersonalização, desincretização, descontextualização, publicidade, programabilidade, cronogênese, topogênese, envelhecimento moral e biológico, criações didáticas e relação antigo/novo do saber. Melzer (2012) baseado no trabalho de Neves
(2009) propôs outro elemento para análise denominado de fidelidade na textualização do saber.

A partir dessas construções teóricas pode-se compreender as aproximações entre os arcabouços teóricos, sendo possível tecer relações. O quadro 1 dá uma relação das categorias propostas por Chevallard (1991) com as de Fleck (2010):

Quadro 1: Relações entre Chevallard e Fleck Melzer (2015) apud Melzer (2016).

\begin{tabular}{|c|c|}
\hline Shevallard (1991) & $\begin{array}{c}\text { Fleck (2010) } \\
\text { Siência Especializada }\end{array}$ \\
\hline Saber a Ensinar & $\begin{array}{c}\text { Ciência dos Periódicos e dos Manuais) } \\
\text { Saber Ensinado }\end{array}$ \\
\hline------------------ & Ciência dos Livros Didáticos \\
\hline
\end{tabular}

A partir dessa relação pode-se desenvolver um esquema (sistematização) do processo (caminho) de construção do saber: 
Figura 3: sistematização entre Chevallard (1991) e Fleck (2010), produzida pelo autor.

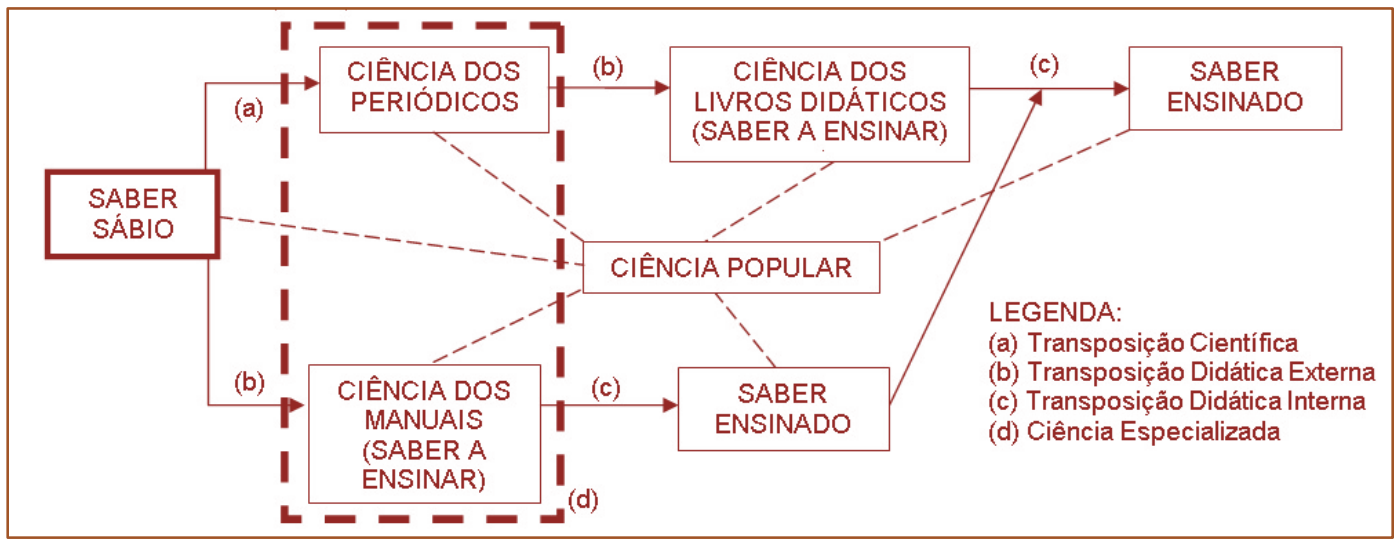

Entende-se que a Ciência dos Manuais constrói o saber ensinado do futuro professor em sala de aula. Além de que a ciência dos periódicos serve de base para a ciência dos livros didáticos, forjando saber a ensinar que se torna saber ensinado. Ou seja, o mecanismo padrão de Transposição Didática e Tráfego de Pensamentos como enunciado por Chevallard (1991) e Fleck (2010).

\section{O EXPERIMENTO DE RUTHERFORD: ANOTAÇÕES DESDE O SABER SÁBIO}

Inicialmente, temos de entender que $\mathrm{E}$. Rutherford não trabalhou sozinho na sequencia experimental que elucidou a possibilidade da existência de um núcleo atômico. Ele comandou uma equipe formada pelos seguintes pesquisadores sob sua orientação: Geiger, Marsden, Crowther, Royds e Darwin. Esta equipe publicou os seguintes trabalhos com os dados experimentais colhidos: (a) The scattering of $\alpha$ particle by matter (1910), publicado na Proc. Royal
Society por H. Geiger; (b) The scattering of $\alpha$ and $\beta$ particles by matter and the structure of the atom (1911), publicado na Philosophical Magazine por E. Rutherford; (c) The laws of deflexion of $\alpha$ particles through large angles (1913), publicado por H. Geiger e E. Marsden na Philosophical Magazine.

Desses três trabalhos compreende-se que houve vários aparatos experimentais e vários testes conduzidos para se chegar a possibilidade levantada por Rutherford de que o átomo teria um núcleo central.

Geiger (1910) em seu artigo explica como a equipe de Cavendish desenvolveu um estudo experimental para explicar o desvio de partículas radioativas em laminas de diferentes materiais. Foram testados: prata (silver), cobre (cooper), Aluminio (Aluminium), Ouro (Gold) e Latão (Tin). O aparato experimental usado foi uma ampola com uma fonte de $\mathrm{RaBr} 2$ e os dados de desvios foram organizados em uma tabela, como mostra na figura 4:

Figura 4: A esquerda temos o aparato usado por Geiger e equipe para medir os desvios e a direita o gráfico com os valores de desvio mostrando a preferencia pelo Ouro com base em valores experimentais.

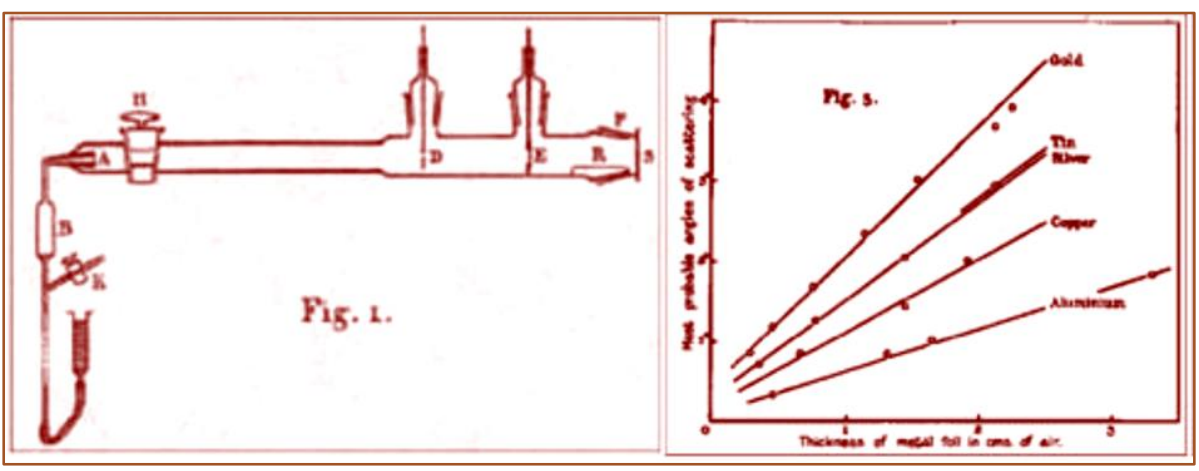


Assim, este artigo apresenta com dados experimentais a preferencia da equipe de Rutherford em usar a lamina de Ouro como o material que permite uma laminas mais finas e com os melhores valores de desvios de partículas radioativas. Geiger e Marsden (1913) também testam os mesmo materiais em laminas e verificam novamente que o Ouro apresenta os melhores valores experimentais para medida de desvios de partículas radioativas.
Após este artigo os relatos de Rutherford (1911) e de Geiger e Marsden (1913) buscam mostrar os procedimentos experimentais de outro experimento do espalhamento de partículas alfa na lâmina de Ouro. Os dados decorrentes desse experimento foram analisados por E. Rutherford. Na figura 5 mostra-se o aparato experimental utilizado e apresentado em Geiger e Marsden (1913) e o resultado gráfico dos cálculos conduzidos por Rutherford (1911) dos desvios de partículas:

Figura 5: A esquerda apresenta-se os dados de desvios calculados e a direita o aparato experimento usado por Geiger e Marsden (1913).

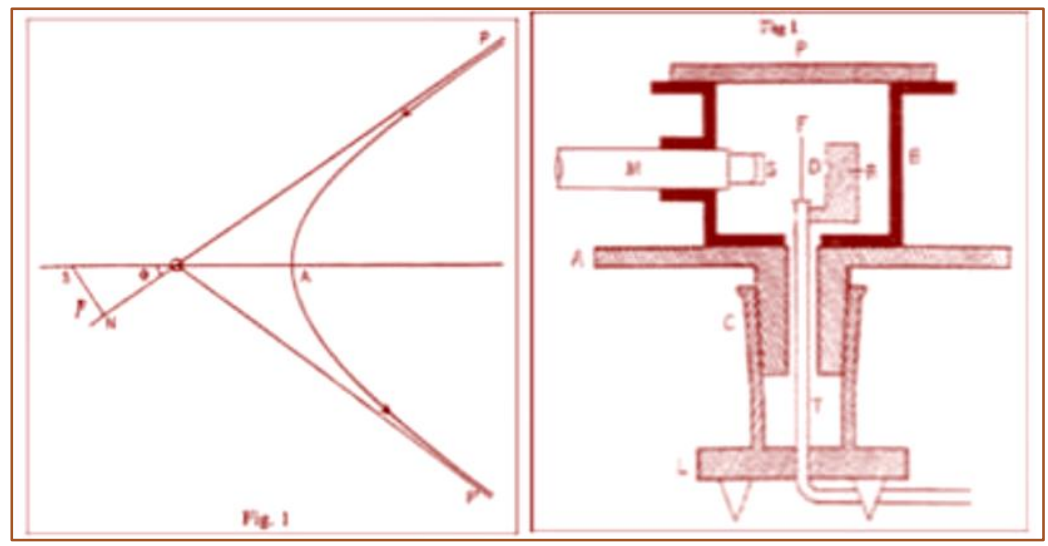

E a partir da análise dos dados Rutherford (1911) compreende que:

Foi suposto que o átomo consiste em uma carga central provavelmente concentrada em um ponto, e as largas deflexões de partículas $\alpha$ e $\beta$ são principalmente devido a passagem através de um forte campo central (RUTHERFORD, 1911, p. 686, tradução nossa).

A partir dos dados analisados por Rutherford (1911) sugere que átomo possa ter uma região densa e carregada vindo a ter carga positiva ou negativa e uma outra região vazia com carga oposta a região central. Dessa forma, segundo os dados experimentais o modelo de Thomson encontrava a sua primeira anomalia.

\section{OS LIVROS DIDÁTICOS DE QUÍMICA: REPRODUÇÃO OU INOVAÇÃO NA TRANSPOSIÇÃO DIDÁTICA?}

Ao todo nesta pesquisa foram analisados 14 livros didáticos destinados ao ensino superior e 26 livros didáticos destinados ao ensino médio de 1931 a 2016 ${ }^{1}$. O saber sobre o experimento de Rutherford foi analisado em cada livro e categorizado em 10 tipos de transposição didática que foi compreendido como estilos de pensamento sobre o experimento de Rutherford:

1 Todos os livros didáticos foram analisados utilizando a técnica da análise de conteúdo como proposta por Bardin (2010), consistindo nas etapas de a) pré-análise; b) exploração do material; c) tratamento dos resultados e interpretações. 
Quadro 2: Estilos de pensamento sobre o experimento de Rutherford

\begin{tabular}{|c|c|c|c|}
\hline $\begin{array}{l}\text { Estilos de } \\
\text { Pensamento } \\
\text { de } \\
\text { Transposição } \\
\text { Didática }\end{array}$ & Características do Estilo de Pensamento & $\begin{array}{l}\text { Quantidade } \\
\text { de Livros } \\
\text { Didáticos ao } \\
\text { ensino } \\
\text { superior }\end{array}$ & $\begin{array}{l}\text { Quantidade } \\
\text { de Livros } \\
\text { Didáticos }\end{array}$ \\
\hline 1 & $\begin{array}{c}\text { Representação do aparato experimental altamente } \\
\text { simplificado. Somente a menção de Rutherford no } \\
\text { experimento. Menção a um único experimento de } \\
\text { desvio de partículas radioativas. }\end{array}$ & 4 & 5 \\
\hline 2 & $\begin{array}{l}\text { Representação do aparato experimental com mais } \\
\text { dados, mais completo. Menção de Rutherford no } \\
\text { experimento. Menção a um único experimento de } \\
\text { desvio de partículas radioativas. }\end{array}$ & 1 & 6 \\
\hline 3 & $\begin{array}{c}\text { Representação do aparato experimental com dados e } \\
\text { a inserção do Polônio como elemento radioativo do } \\
\text { experimento. Menção de Rutherford no experimento. } \\
\text { Menção a um único experimento de desvio de } \\
\text { partículas radioativas. }\end{array}$ & 0 & 8 \\
\hline 4 & $\begin{array}{c}\text { Representação do aparato experimental com mais } \\
\text { dados, mais completo. Menção a Geiger e Marsden } \\
\text { junto a Rutherford no experimento. Menção a um único } \\
\text { experimento de desvio de partículas radioativas. }\end{array}$ & 2 & 5 \\
\hline 5 & $\begin{array}{l}\text { Representação do aparato experimental com dados e } \\
\text { a inserção do Polônio como elemento radioativo do } \\
\text { experimento. Menção a uma equipe que junto a } \\
\text { Rutherford desenvolveram uma série de experimentos } \\
\text { sobre desvios de partículas radioativas. }\end{array}$ & 1 & 2 \\
\hline 6 & $\begin{array}{l}\text { Representação do aparato experimental simplificado } \\
\text { com a menção de um transferidor para medição dos } \\
\text { ângulos de desvio das partículas alfa. Somente a } \\
\text { menção de Rutherford no experimento. Menção a um } \\
\text { único experimento de desvio de partículas radioativas. }\end{array}$ & 1 & 0 \\
\hline 7 & $\begin{array}{l}\text { Representação do aparato experimental simplificado } \\
\text { com menção a um microscópio para observação dos } \\
\text { desvios de partículas alfa. Somente a menção de } \\
\text { Rutherford no experimento. Menção a um único } \\
\text { experimento de desvio de partículas radioativas. }\end{array}$ & 1 & 0 \\
\hline 8 & $\begin{array}{l}\text { Representação do aparato experimental com mais } \\
\text { dados, mais completo, usando o Rádio como fonte } \\
\text { radioativa e descrevendo a utilização de um } \\
\text { microscópio móvel. Somente a menção de Rutherford } \\
\text { no experimento. Menção a um único experimento de } \\
\text { desvio de partículas radioativas. }\end{array}$ & 2 & 0 \\
\hline 9 & $\begin{array}{c}\text { Representação do aparato experimental simplificado } \\
\text { com a menção do Rádio como fonte radioativa. } \\
\text { Somente a menção de Rutherford no experimento. } \\
\text { Menção a um único experimento de desvio de } \\
\text { partículas radioativas. }\end{array}$ & 1 & 0 \\
\hline 10 & $\begin{array}{l}\text { Representação do aparato experimental altamente } \\
\text { simplificado. Somente a menção de Rutherford com } \\
\text { Marsden e Geiger no experimento. Menção a um único } \\
\text { experimento de desvio de partículas radioativas. }\end{array}$ & 1 & 0 \\
\hline \multicolumn{2}{|c|}{ TOTAL DE LIVROS } & 14 & 26 \\
\hline
\end{tabular}


6. TABELA 1: LIVROS DIDÁTICOS ANALISADOS COM BASE NOS ESTILOS DE PENSAMENTO SOBRE A TRANSPOSIÇÃO DIDÁTICA DO EXPERIMENTO DE RUTHERFORD.

De acordo com a tabela 1 percebe-se que há uma reprodução do saber que acontece na Universidade através de obras que podem ser usadas como referencia para a formação de professores e futuros profissionais da área de química. Esses livros didáticos podem ter influenciado o tratamento de alguns livros didáticos de química voltados para o ensino médio. Isso se verifica para os estilos de pensamento de 1 a 6 .

Para o primeiro Estilo de Pensamento temos 4 livros didáticos que trazem as mesmas características na representação do experimento de Rutherford, um exemplo apresenta-se na figura 6.

Figura 6: representações do experimento de Rutherford: a esquerda é a imagem retirada de Brady e Holum (1988) e a direita é a imagem do livro Chemical Bond Approach (1960).

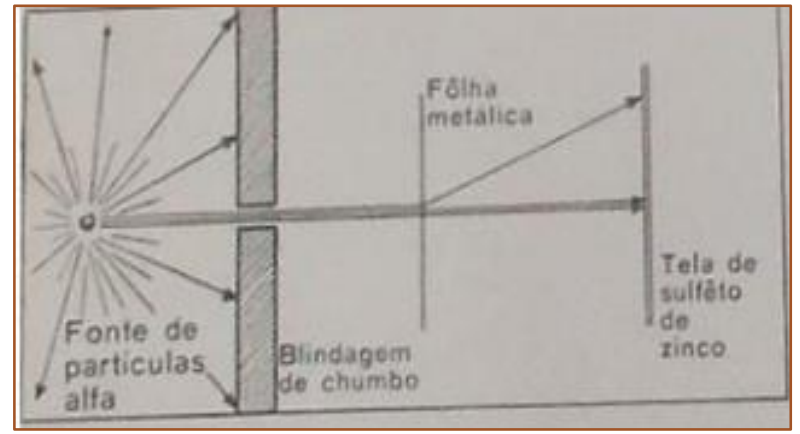

Observa-se que há uma similaridade da representação do livro de Brady e Holum com o livro Chemical Bond Approach. O experimento é apresentado com pouco detalhes, de uma forma altamente simplificada. Os outros 3 livros também apresentam representações similares, guardadas algumas diferenciações.

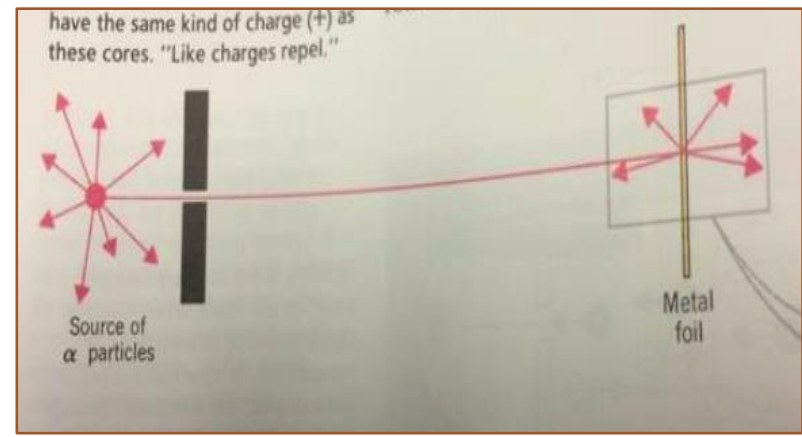

Para o segundo Estilo de Pensamento de Transposição Didática encontrou-se apenas 1 livro didático destinado ao ensino superior. Com algumas diferenças a representação do experimento se aproximaram da representação apresentada em livros para o ensino médio:

Figura 7: representações do experimento de Rutherford: a esquerda é a imagem retirada de Chang (2007) e a direita é a imagem do livro de Usberco e Salvador (1996)

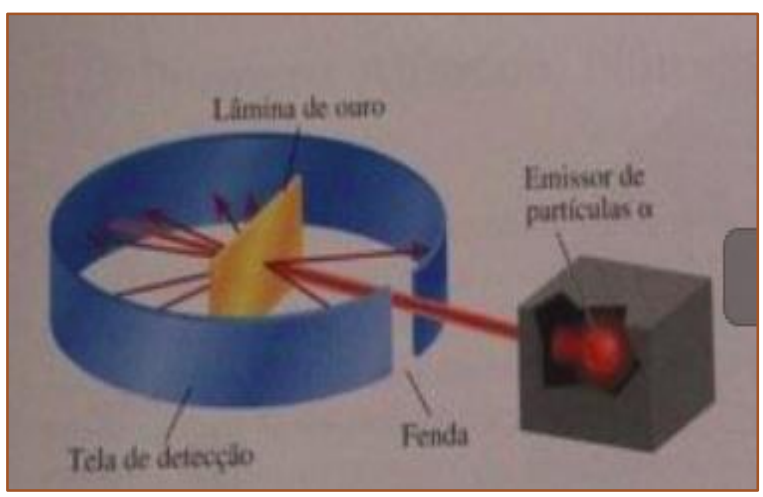

O livro apresentou o experimento de Rutherford dotado de mais informações, porém, com algumas lacunas como a fonte radioativa (só apresentam como fonte de emissão alfa) a estrutura do equipamento

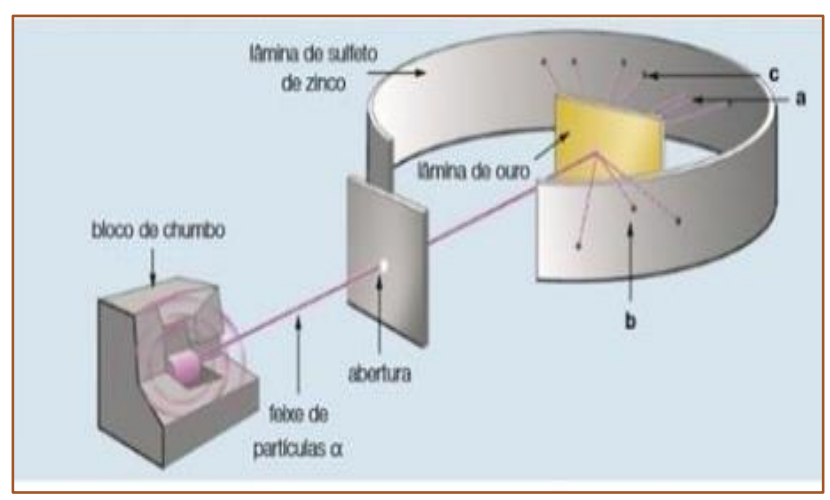

usado para as medições (somente apresentam a folha de Ouro, bombardeada e a tela de detecção para definir os ângulos dos desvios). Esta representação guarda uma certa semelhança com o apresentado no livro 
de Usberco e Salvador (1996).

Para o terceiro Estilo de Pensamento não foram encontrados livros didáticos para $\mathrm{O}$ ensino superior na amostra apreciada. Nos Estilos de Pensamento 4 e 5 foram classificados 2 livros (Estilo de Pensamento 4) e 1 livro (Estilo de Pensamento 5). Estes apresentam representações semelhantes a dos Estilos de Pensamento 1, 2 e 3. A nova característica encontrada está na descrição da condução do experimento de Rutherford.

Para o Estilo de Pensamento 4 há a menção de Geiger e Marsden como parceiros de Rutherford na execução do experimento.

No Estilo de Pensamento 5 o livros didático Curso de Química 1 (SILVA e SILVA, 1979) coloca o termo Equipe sugerindo que existiam vários pesquisadores trabalhando em colaboração com Rutherford. Nos livros na figura 8: destinados ao ensino médio, para o estilo de pensamento 5, somente um autor de livro didático (REIS, 2006 e 2011) apresentou menção a vários experimentos totalizando duas menções em livros. Porém, o autor insere o Polônio como elemento radioativo usado o que se mostra inconsistente com o artigo de Geiger e Marsden (1913).

O que podemos depreender é que em certos livros voltados para a formação de profissionais na área de química $\mathrm{O}$ experimento de Rutherford ganha elementos que não foram encontrado nos livros didáticos para o Ensino Médio. Estes elementos são: 1) a menção de um transferidor; 2) a menção de luneta, móvel e fixa, para observar os desvios; 3) a menção do elemento Rádio como fonte emissora de partículas alfa radioativas. Algumas representações desses livros estão

Figura 8: representações do experimento de Rutherford: em (a) retirada do livro de Russel (1995); em (b) retirada do livro de Mahan (2009) ; em (c) retirada do livro de Hogg et al (1953) e em (d) retirada do livro de Young (1960).

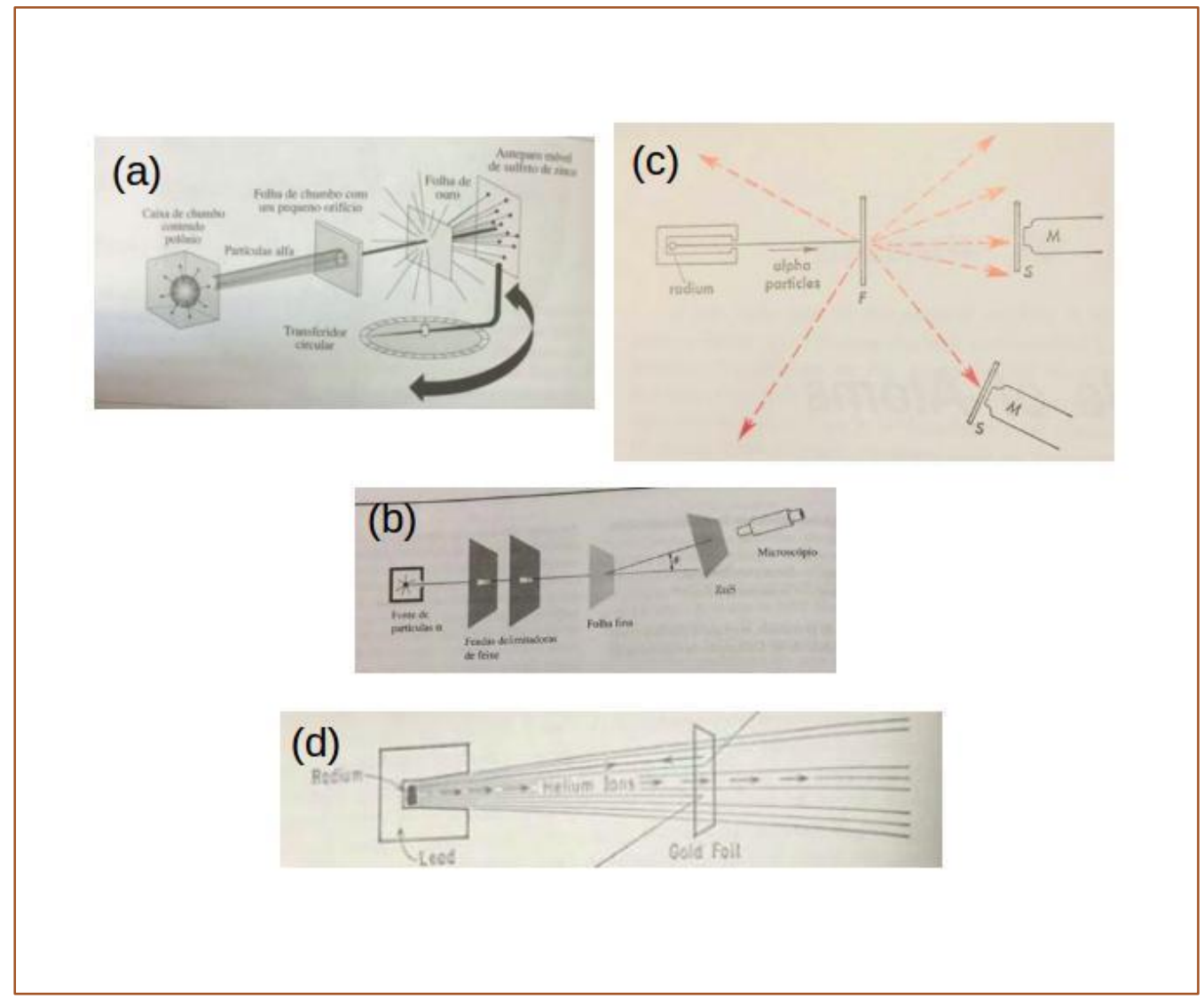


Nestes estilos de pensamento o que se varia é o grau de detalhes da representação com a inserção dos novos elementos, por exemplo, no livro LQ1 há na legenda da figura 2.10 a seguinte explicação:

Desvio de partículas alfa em folha metálica. $O$ telescópio viaja em uma trilha circular da câmara de vácuo que contem a folha metálica. A maioria das partículas alfa passa pela folha metálica diretamente sem sofrer desvios, mas algumas são defletidas em grandes ângulos de desvio (PETRUCCl e HARWOOD, 1993, p. 40).

Desta forma, os autores dão uma compreensão que se completa com a representação do microscópio móvel e do experimento montado associada da explicação na legenda da imagem que explica certos elementos que não aparecem na imagem.

Para o Estilo de Pensamento 10 o experimento é representado com poucos detalhes, sem dar uma noção precisa do experimento, mas na explicação do procedimento do experimento, o autor do LQ10 relata que Geiger e Marsden atuaram como pesquisadores parceiros nos trabalhos com Rutherford, destacando a atividade coletiva da ciência.

O que podemos depreender é que há dois conjuntos de Estilos de Pensamento distintos: um primeiro que entra em concordância com os dados colhidos por Melzer (2016) abrindo a possibilidade para a hipótese de que autores de livros didáticos de Ensino Médio podem ter utilizado como referencia livros didáticos de ensino superior. E um segundo conjunto de Estilos de Pensamento, mais completos, e com novos elementos que melhoram a compreensão do experimento de Rutherford, em alguns casos os relatos são altamente detalhados dando uma visão bem próxima do experimento de espalhamento de partículas alfa.

O que também pode-se depreender é que há uma distancia entre os artigos de Geiger e Marsden (1913) e de Rutherford (1911), pois, nos relatos de todos os 14 livros didáticos há a menção de um único experimento, o que se encontra em inconsistência com a análise dos artigos originais. Outro ponto que ressalta-se é que não há explicação sobre o porque de se escolher o Ouro. Recorda-se que o Ouro foi escolhido após testes de experimentais de espalhamento de partículas e que este material apresentou os melhores resultados com a menor espessura possível, isso mostrase pelo gráfico representado na figura 2 . Porém, os livros analisados somente partem do ultimo experimento o qual Rutherford usou para modelar matematicamente a possibilidade de existência de um núcleo atômico no artigo de 1911.

Do ponto de vista do modelo de análise proposto por Melzer (2016) este apresentouse interessante para analisar livros didáticos voltados para o ensino superior, porém, necessita de algumas reelaborações no que toca ao aumento das possibilidades de transposição didática externa, ou seja, o esquema dá a impressão de que somente há um tipo de Transposição Didática, quando na verdade há a possibilidade de se haver outros tipos de Transposição tais como:

1) transposição do Saber Sábio diretamente para o livro didático de Ensino Médio (Ciência dos Livros Didáticos) ou para o livro didático de Ensino Superior (Ciência dos Manuais), no caso dos participantes do experimento ou pesquisadores próximos quando escreveram livros para divulgação científica ou para o ensino científico em Escolas e Universidades;

2) transposição do Saber Sábio para um artigo científico e deste para um livro didático da Ciência dos Manuais ou Ciência dos Livros Didáticos, dando a compreender que o autor do livro usou os artigos como referencia;

3) transposição da Ciência dos Manuais para a Ciência dos Livros Didáticos, dando a compreensão de que o autor de livros didático para o ensino médio pode ter se baseado em livros mais populares no meio acadêmico para o ensino superior. Esta hipótese abre uma possibilidade de se compreender que houveram reprodução de certos Estilos de Pensamento em detrimento de outros mais completos.

\section{CONSIDERAÇÕES FINAIS}

O objetivo deste capítulo foi fazer uma síntese de três trabalhos que constroem um caminho de estudo em torno do experimento de Rutherford e da construção de uma proposta teórica para análise de saberes. A partir dos dados uma hipótese que levanto é se alguns 
desses livros de ensino superior não influenciaram a transposição em livros para o ensino médio no Brasil, devido a similaridade de Estilos de Pensamento encontrados. Destaca-se também que os livros não trazem informações sobre como se chegou ao Ouro e também não trazem a menção a outros experimentos, somente ao que verificou os desvios e a possibilidade de ocorrência de um núcleo atômico.

Nesse sentido, podemos compreender que na verdade não houve inovação na

\section{REFERÊNCIAS}

[1] Aichinger, E. C. Química 1. São Paulo: EPU, 1979.

[2] Bardin, L. Análise de conteúdo. Lisboa: Edições 70, 2010.

[3] Brady, J. E. HOLUM, J. R. Fundamentals of chemistry. New York: John Willey \& Sons, 1988.

[4] Brady, J. E. HUMISTON, G. E. Química geral. São Paulo: LTC, 1995.

[5] Chang, R. Química geral. São Paulo :AMGH editora, 2007.

[11] Feltre, R. Setsuo, Y. Atomística. São Paulo: Moderna, 1971

[12] Feltre, R. Setsuo, Y. Atomística. São Paulo: Moderna, 1972.

[13] Feltre, R. Setsuo, Y. Química geral. São Paulo: Moderna, 1975.

[14] fleck, L. A gênese e desenvolvimento de um fato científico. Belo Horizonte: Faberfactum, 2010.

[15] Geiger, $H$. The scattering of the $\alpha$-particles by matter. Proceedings of the Royal Society. V. 83, Fev, 1910, p. 492-504.

[16] Geiger, H. MARSDEN, E. LXI. The laws of deflexion of $\alpha$ particles through large angles. Philosophical Magazine. S. 6, V. 25, N. 48, Abr, 1913, p. $604-624$.

[17] hogg, E. Bickel, S. NICHOLSON, A. WIK, E. Chemistry a modern approach. Florida: DVN, 1953.

[18] Kotz, J. C. TREICHEL, P. M. WEAVER, G C. Química geral. São Paulo :CENGAGE Learning. 2005.

[19] Lisboa, J. C. F. (Org.). Ser protagonista: química. São Paulo: SM, 2010.

[20] Mahan, B. M. Química um curso universitário. São Paulo: Edgard Blucher, 2009.

[21] Masterton, W. Hurley, C. N. Chemistry. Philadelphia: Saunders, 1989.

[22] Masterton, W. L. Slowinski, E. J. STANITSKI, C. L. Princípios de química. Rio de Janeiro: Editora Guanabara, 1990.

[23] Melzer, E. E. M. A Teorias De Chevallard e Fleck: Relações Entre a Transposição Didática e o Tráfego de Pensamentos. In: Congresso Nacional de Educação, 12., Curitiba, Anais do XII Congresso Nacional de Educação, Curitiba: XII EDUCERE, 2015, p. 460-474. construção das transposições didáticas sobre o experimento de Rutherford para livros do ensino médio; houve uma reprodução que foi baseada em livros destinados ao ensino superior. Agora a próxima etapa desta pesquisa é analisar qual a construção mental do experimento de Rutherford para professores universitários, professores da educação básica, estudantes dos cursos de licenciatura em química, ciências e de educação do campo e estudantes do ensino fundamental ( $9^{\circ}$ ano) e do ensino médio.

[6] Ciscato, C. A. M. PEREIRA, L. F. Planeta Química. São Paulo: Ática, 2011.

[7] Chemical Bond Approach. Química: Parte 1. Brasília: UNB, 1960.

[8] Chevallard, Y. La transposition didactique. Buenos Aires: Aique, 1991.

[9] Feltre, R. Química: volume 1. São Paulo: Moderna, 1970.

[10] Feltre, R. Química: volume 1. São Paulo: Moderna, 2006.

[24] Melzer, Ehrick E. M. Do saber sábio ao saber a ensinar: a transposição didática para o conteúdo modelo atômico em livros didáticos de química de 1931 a 2012. Dissertação de mestrado. PPGECM, UFPR. 2012.

[25] Melzer, E. E. M. O experimento de Rutherford: transposição e estilos de pensamento na história do livro didático de química In: Encontro Nacional de Ensino de Química, XVIII, 2016, Florianópolis, Anais, Florianópolis, 2016, p. 1-12.

[26] Melzer, E. E. M. experimento de Rutherford em livros de química destinados ao ensino superior: transposição e estilos de pensamento. In: XI Encontro Nacional de Pesquisa em Educação em Ciências - XI ENPEC, 2017, Florianópolis, Anais, Florianópolis, 2017, p. 1-12.

[27] Mortimer, C. E. Chemistry a conceptual approach. Londres: Reinhold, 1967.

[28] Mortimer, E. F. MACHADO, A. H. Química: volume 1. São Paulo: Scipione, 2011.

[29] Petrucci, R. H. HARWOOD, W. S. General chemistry. New Jersey: Prentice Hall, 1993.

[30] Peruzzo, F. M. CANTO, E. L.Química: volume único. São Paulo: Moderna, 1996.

[31] Peruzzo, F. M. CANTO, E. L.Química na abordagem do cotidiano: volume 1. São Paulo: Moderna, 2006.

[32] Peruzzo, F. M. CANTO, E. L.Química: volume único. São Paulo: Moderna, 2011.

[33] Politi, E. Química: curso completo. São Paulo: Moderna, 1990.

[34] Russell, J. B. Química geral. São Paulo: PEARSON, 1995.

[35] Rutherford, E. The scattering of $\alpha$ and $\beta$ particles by matter and the structure of the atom. Philosophical Magazine. S. 6, V. 21, N. 125, Fev, 1911, p. 
[36] Reis, M. Química volume 1: meio ambiente, cidadania, tecnologia. São Paulo: FTD, 2006.

[37] Reis, M. Química 1. São Paulo: Ática. $2011.669-688$.

[38] Slabaugh, W. H. PARSONS, T. D. Química geral. São Paulo: LTC, 1975.

[39] Sardella, A. LEMBO, A. Química: volume 1. São Paulo: Ática, 1981.

[40] Santos, W. MOL, G. (Org.). Química e sociedade. São Paulo: Nova Geração, 2006.

[41] Santos, W. MOL, G. (Org.). Química cidadã. São Paulo: Nova Geração, 2011.

[42] SANTOS, W. MOL, G. (Org.). Química cidadã. São Paulo: Nova Geração, 2013.

[43] Silva, R. H. SILVA, E. B. Curso de química. São Paulo: HARBRA, 1996.
[44] silva, R. S. HASHIMOTO, R. R. Química. São Paulo: Nova Cultura, 1996.

[45] Silva, R. H. SILVA, E. B. Curso de química 1. São Paulo: Harbra, 1979.

[46] young, J. A. ELEMENTS OF GENERAL CHEMISTRY. NEW JERSEY: PRENTICE HALL, 1960.

[47] Usberco, J. SALVADOR, E. Química: volume único. São Paulo: Saraiva. 1996.

[48] Usberco, J. SALVADO, E. Química: volume 1. São Paulo: Saraiva. 2002.

[49] Usberco, J. SALVADOR, E. Química: volume 1. São Paulo: Saraiva. 2006.

[50] Usberco, J. SALVADOR, E. Química essencial. São Paulo: Saraiva. 2011.

[51] Utimura, T. Y. LINGUANOTO, M. Química fundamental. São Paulo: FTD. 1990. 


\section{Capítulo 9}

\section{HISTÓRIA DA CIÊNCIA E APLICACÕES NO ENSINO BÁSICO DE BIOLOGIA: UMA INVESTIGAÇ̃̃O DOS ANAIS DOS ENPECS DE 2007 A 2015.}

\section{Luana Beatriz Xavier Nunes}

\section{Magda Medhat Pechliye}

Resumo:Este trabalho tem como objetivo fazer um levantamento das publicações relacionadas à História da Ciência nos anais dos ENPECs (2007 a 2015) analisando aquelas relacionadas ao desenvolvimento de propostas voltadas ao ensino de Biologia na Educação Básica, buscando indicar quais atividades e quais recursos didáticos são mais utilizados nessas propostas. Para isso, foi realizado um levantamento bibliográfico nos anais dos encontros e selecionados 12 artigos que continham propostas ou aplicações de atividades com inclusão de História da ciência no ensino, dentre eles, cinco apresentam apenas propostas de materiais para utilização em sala de aula, quatro trazem análises de efetivas aplicações no ensino de Biologia, e três apresentam propostas de sequências didáticas ou atividades. Os principais recursos utilizados são textos históricos originais e adaptados abordados a partir de leituras e discussões, aulas práticas, trabalhos e atividades em grupo.

Palavras chave: ensino de biologia, história da ciência, propostas para sala de aula. 


\section{INTRODUÇÃO}

Nos últimos anos, diversos trabalhos têm abordado a utilização de História da Ciência $(\mathrm{HC})$ na sala de aula, reconhecendo sua importância no ensino contextual de ciências e biologia, tornando as aulas mais reflexivas e desafiadoras, além de contribuir para um melhor entendimento dos conceitos científicos (ALLCHIN, 2013; CARNEIRO e GASTAL, 2005; MARTINS, 1998; MATTHEWS, 1995; PRESTES e CALDEIRA, 2009). De acordo com Matthews (1995) a História e Filosofia da Ciência (HFC) pode humanizar as ciências tornando-a menos abstrata e mais interessante aos alunos, mostrando também, a partir de episódios históricos, o processo gradativo da construção do conhecimento científico, seus métodos e limitações.

Neste sentido, os parâmetros curriculares nacionais, tanto do Ensino Fundamental como do Ensino Médio também recomendam a inserção de $\mathrm{HC}$ no ensino. Orientam que a dimensão histórica pode ser introduzida nas aulas, abordando a história das ideias científicas, tornando possível aos alunos a compreensão de que há uma ampla rede de relações entre a produção científica e o contexto econômico, político e social (BRASIL, 1998, 2002).

Sabendo disso, a HC pode ser utilizada em sala de aula como um recurso didático, auxiliando na superação de obstáculos que existem no ensino dos conteúdos de Biologia. Dentre as possibilidades se encontram a utilização de textos de fontes primárias e/ou secundárias para análise e discussão, replicação de experimentos, jogos didáticos, produção de narrativas históricas, linhas do tempo, entre outras atividades que podem estar incluídas em sequências didáticas ou abordagens pontuais (BELTRAN et al., 2016). Recomenda-se também uma abordagem direta e explícita, reflexiva e contextualizada (LEDERMAN, 2007), a partir de leituras e discussões inseridas em temas pertinentes ao conteúdo que se objetiva ensinar, relacionado à realidade escolar do aluno (MATTHEWS, 2012). Entretanto, alguns desafios podem surgir diante das aplicações, como a formação inadequada dos professores, escassez de matérias didáticos de boa qualidade relacionados a área e a falta de tempo diante dos programas exigidos pelas escolas (SOUZA e PRESTES, 2015). Quanto a isso, alguns trabalhos apresentam alternativas para a superação desses problemas como em Matthews (1995) que sugere uma abordagem inclusiva voltada à introdução de episódios históricos nas aulas de ciências. Essa abordagem mais pontual fornece ao professor autonomia na construção do programa de aprendizagem, podendo incluir diversos materiais didáticos conforme os objetivos previamente estabelecidos e de acordo com o perfil da turma e da escola (PRESTES e CALDEIRA, 2009).

Partindo desse ponto de vista, alguns trabalhos vêm sendo publicados com a intenção de analisar a produção bibliográfica atual sobre propostas de utilização de $\mathrm{HC}$ em sala de aula (MOURA et al., 2015; SILVA e GATTI, 2015; AUGUSTO, 2015; PEREIRA e TRIVELATO, 2015), os resultados sugerem que apesar de bem estabelecidas as vantagens dessa abordagem no ensino de ciências, o número de produções acadêmicas ainda é muito reduzido, sendo que a maioria se concentra no ensino de física ou são trabalhos essencialmente teóricos.

Dentre estes, o trabalho realizado por Augusto (2015) propôs analisar dissertações e teses sobre História e Filosofia da Biologia no ensino produzidas entre 1972 e 2010 constatando que dos setenta trabalhos encontrados, apenas sete apresentaram propostas de ensino voltadas ao desenvolvimento de temas em História e Filosofia da Ciência e nove abordaram o processo de formação de professores com a produção de materiais didáticos e sequências de ensino sobre o tema.

Apesar da relevância dos trabalhos teóricos que enfatizem a importância da abordagem histórica contextualizada no ensino de ciências e biologia, falta ainda um maior número de estudos que possibilitem uma avaliação de como essa perspectiva histórica tem sido trabalhada na sala de aula e em que contextos isso tem ocorrido. Segundo Carneiro e Gastal (2005), não é suficiente afirmar a necessidade de adotar uma perspectiva histórica no ensino de biologia sem o desenvolvimento de instrumentos para que esta proposta seja aplicada satisfatoriamente. Além de repensar os cursos de formação inicial e continuada de professores é necessário um esforço concentrado na produção de materiais que forneçam indicadores acerca de como trabalhar essa abordagem na escola básica.

Frente a essa situação, o objetivo desse trabalho é fazer um levantamento das 
publicações relacionadas à História da Ciência nos anais dos ENPECs (2007 a 2015) analisando aquelas relacionadas ao desenvolvimento de propostas voltadas ao ensino de Biologia na Educação Básica, buscando indicar quais atividades e quais recursos didáticos são mais utilizados nessas propostas. A escolha desse evento se dá pelo fato de ser um encontro importante para os pesquisadores da área de ensino em ciências, promovido a cada dois anos pela Associação Brasileira de Pesquisa em Educação em Ciências (ABRAPEC) tendo como objetivo favorecer a interação entre os pesquisadores de diversas áreas da ciências e saúde, tratando de temas de interesse da comunidade de educadores.

\section{METODOLOGIA}

Para esta pesquisa de natureza empírica, foi realizado um levantamento de trabalhos nas atas dos últimos cinco encontros, ENPECs de 2007 a 2015 (VI a X ENPEC). Para seleção dos trabalhos, foram estipulados alguns critérios como: deveriam apresentar propostas para sala de aula, sendo uma sequência didática integral ou parcial, atividade ou material didático; ou aplicações em sala de aula contendo a descrição e análise da mesma; as propostas ou aplicações deveriam se referir à História da Ciência no ensino básico de Biologia e serem trabalhos completos publicados, para melhor leitura e análise das propostas.

Inicialmente os trabalhos foram selecionados a partir da busca por descritores localizados nas palavras-chaves do texto, como: ensino de biologia, sequência didática, história da biologia, materiais didáticos e propostas. Nos últimos três eventos a busca se restringiu à linha temática"História, filosofia e sociologia da ciência na educação em ciências", uma das categorias estipuladas pelo ENPEC para publicações a partir de 2011. A princípio foram feitas leituras dos títulos e resumos dos trabalhos que possuíam ao menos um dos descritores estabelecidos nas palavras chaves. Os artigos que apresentavam propostas, materiais ou sequências didáticas para o ensino de Biologia não relacionadas à História da Ciência foram descartados. Após a seleção dos artigos que obedeciam aos critérios determinados, os trabalhos foram lidos na íntegra, e assim escolhidos definitivamente.

Para a análise, foi realizado um fichamento de cada artigo selecionado, cada ficha continha informações básicas como o título do artigo, autores e ano do encontro; a sua respectiva categoria, se apresentava uma proposta de sequências didática, atividade, material didático ou aplicação; recursos didáticos utilizados ou sugeridos pelo artigo; estratégias recomendadas ou aplicadas e um resumo do artigo publicado. Os fichamentos foram analisados segundo o referencial teórico apresentado, correspondendo às categorias de recursos didáticos e estratégias apresentadas por cada proposta ou aplicação contida nos trabalhos selecionados.

\section{RESULTADOS E DISCUSSÃO}

Após as buscas, foram selecionados 12 artigos (QUADRO 1) que se enquadravam nos critérios: 1) apresentando propostas de materiais, sequências didáticas ou atividades com inclusão de HC no ensino; 2) Análises de aplicações em sala de aula. Os resultados e discussão serão apresentados de acordo com algumas das categorias do fichamento.

Quadro 1: Número de publicações com propostas ou aplicações de HC no ensino básico de Biologia comparado ao número total de trabalhos apresentados.

\begin{tabular}{|l|l|l|l|l|l|l|l|}
\hline \multicolumn{2}{|c|}{ VII-2007 VII- 2009 VIII -2011 IX -2013 } & \multicolumn{2}{l|}{ X -2015 } & Total \\
\hline $\begin{array}{l}\text { № de trabalhos com } \\
\text { propostas ou } \\
\text { aplicações }\end{array}$ & 0 & 0 & 4 & 3 & 5 & 12 \\
\hline $\begin{array}{l}\text { No total de trabalhos } \\
\text { apresentados no } \\
\text { ENPEC }\end{array}$ & 405 & 425 & 1009 & 1526 & 1768 & 5133 \\
\hline
\end{tabular}

A relação de todos os artigos selecionados encontra-se no Quadro 2, dentre eles, quatro se relacionam a propostas de atividades ou sequências didáticas, cinco à elaboração de 
materiais históricos que podem ser utilizados como recursos para o ensino e três a análises de aplicações de sequências ou atividades ligadas ao tema. O maior número de publicações com apenas a elaboração de materiais ocorreu no ano de 2011, já nos encontros seguintes, os materiais dividiram espaço com as propostas de sequências de atividades e aplicações, podendo sugerir uma maior aproximação do tema à sala de aula.

Quadro 2: Relação dos artigos selecionados para análise. PM=propostas de materiais; $A A=$ análise de aplicações; PSD= propostas de atividades ou sequências didáticas.

\begin{tabular}{|c|c|c|c|c|c|c|}
\hline № & Categoria & Tema & Encontro & Autores & Artigos analisados & Breve descrição \\
\hline 1 & PM & Cronobiologia & 2011 & $\begin{array}{c}\text { Maria de } \\
\text { Fátima Neves } \\
\text { Sandrin e } \\
\text { Eduardo Adolfo } \\
\text { Terrazzan }\end{array}$ & $\begin{array}{c}\text { Temas } \\
\text { contemporâneos da } \\
\text { Biologia no Ensino } \\
\text { Médio e a história dos } \\
\text { relógios biológicos }\end{array}$ & $\begin{array}{c}\text { Fundamenta uma } \\
\text { proposta de ensino para } \\
\text { Ensino Médio a partir de } \\
\text { uma investigação } \\
\text { historiográfica sobre } \\
\text { Cronobiologia durante o } \\
\text { século XX. }\end{array}$ \\
\hline 2 & PSD & $\begin{array}{c}\text { Patologia } \\
\text { Infectologia }\end{array}$ & 2011 & $\begin{array}{l}\text { Luiz Augusto } \\
\text { Rezende Filho; } \\
\text { Márcia Bastos } \\
\text { de Sá; Karen } \\
\text { Oliveira e } \\
\text { Simone Franco } \\
\text { de São Tiago. }\end{array}$ & $\begin{array}{l}\text { Pesquisa documental } \\
\text { sobre "Combate à } \\
\text { lepra no Brasil" (1945): } \\
\text { filmes científicos como } \\
\text { fontes para o ensino } \\
\text { de história da ciência }\end{array}$ & $\begin{array}{c}\text { Desenvolve uma análise } \\
\text { de filme, a partir de uma } \\
\text { pesquisa histórica } \\
\text { documental sobre a } \\
\text { hanseníase no Brasil, } \\
\text { refletindo sobre o uso de } \\
\text { audiovisuais como fontes } \\
\text { para o ensino da História } \\
\text { da Ciência. }\end{array}$ \\
\hline 3 & PM & $\begin{array}{c}\text { Genética } \\
\text { humana }\end{array}$ & 2011 & $\begin{array}{l}\text { Eduarda Maria } \\
\text { Schneider; } \\
\text { Lourdes } \\
\text { Aparecida } \\
\text { Della Justina e } \\
\text { Fernanda } \\
\text { Aparecida } \\
\text { Meglhioratti } \\
\end{array}$ & $\begin{array}{l}\text { Eugenia no brasil: } \\
\text { quando um movimento } \\
\text { ideológico se justifica } \\
\text { por um discurso } \\
\text { biológico }\end{array}$ & $\begin{array}{c}\text { Analisa exemplares do } \\
\text { Boletim de Eugenia } \\
\text { brasileiro de 1929, } \\
\text { identificando-os como } \\
\text { fortes estratégias para o } \\
\text { ensino de evolução e } \\
\text { genética. }\end{array}$ \\
\hline 4 & PM & Fisiologia & 2011 & $\begin{array}{l}\text { Alan Dantas } \\
\text { dos Santos } \\
\text { Felisberto e } \\
\text { Maria Elice B. } \\
\text { Prestes }\end{array}$ & $\begin{array}{l}\text { O método } \\
\text { experimental de } \\
\text { Claude Bernard: uma } \\
\text { breve introdução e } \\
\text { apontamentos para } \\
\text { sua utilização no } \\
\text { ensino de biologia }\end{array}$ & $\begin{array}{c}\text { Analisa as contribuições } \\
\text { de Claude Bernard } \\
\text { (1813-1878) à } \\
\text { metodologia } \\
\text { experimental em } \\
\text { fisiologia humana e } \\
\text { animal, podendo ser } \\
\text { utilizado em sala de aula. }\end{array}$ \\
\hline 5 & PM & $\begin{array}{l}\text { Origem da } \\
\text { vida }\end{array}$ & 2013 & $\begin{array}{c}\text { Morcillo Molina } \\
\text { Carolina e } \\
\text { García A Edwin } \\
\text { German }\end{array}$ & $\begin{array}{l}\text { Controvérsia Pasteur } \\
\text { VS Pauchet (sobre a } \\
\text { geração espontânea), } \\
\text { uma ferramenta para o } \\
\text { ensino das ciências. }\end{array}$ & $\begin{array}{c}\text { Adota a controvérsia } \\
\text { Pasteur vs Pouchet no } \\
\text { século XIX sobre a } \\
\text { geração espontânea dos } \\
\text { microrganismos. } \\
\text { Apresenta o estudo para } \\
\text { possível utilização na } \\
\text { sala de aula. }\end{array}$ \\
\hline 6 & PSD & Evolução & 2013 & $\begin{array}{c}\text { Matheus } \\
\text { Luciano Duarte } \\
\text { Cardoso; Thais } \\
\text { Cyrino de Mello } \\
\text { Forato e Maria } \\
\text { Luiza Ledesma } \\
\text { Rodrigues } \\
\end{array}$ & $\begin{array}{c}\text { As ideias } \\
\text { "evolucionistas" de } \\
\text { Lamarck: uma } \\
\text { proposta para a sala } \\
\text { de aula }\end{array}$ & $\begin{array}{c}\text { Apresenta planos de aula } \\
\text { direcionados ao Ensino } \\
\text { Médio, fundamentados } \\
\text { nas práticas de HC no } \\
\text { ensino sobre a teoria da } \\
\text { progressão dos animais } \\
\text { de Lamarck. }\end{array}$ \\
\hline
\end{tabular}


Quadro 2: Relação dos artigos selecionados para análise. $P M=$ propostas de materiais; $A A=$ análise de aplicações; PSD= propostas de atividades ou sequências didáticas (continuação)

\begin{tabular}{|c|c|c|c|c|c|c|}
\hline № & Categoria & Tema & Encontro & Autores & Artigos analisados & Breve descrição \\
\hline 7 & AP & $\begin{array}{l}\text { Fisiologia } \\
\text { humana e } \\
\text { animal }\end{array}$ & 2013 & $\begin{array}{l}\text { Luciana } \\
\text { Romeira de } \\
\text { Jesus e } \\
\text { Jesuína Lopes } \\
\text { de Almeida } \\
\text { Pacca }\end{array}$ & $\begin{array}{l}\text { A construção do } \\
\text { Sistema Circulatório na } \\
\text { História e na Sala de } \\
\text { Aula }\end{array}$ & $\begin{array}{c}\text { Analisa uma SD sobre } \\
\text { Sistema Circulatório } \\
\text { utilizando HC como } \\
\text { facilitadora do processo } \\
\text { de ensino-aprendizagem. }\end{array}$ \\
\hline 8 & AP & $\begin{array}{l}\text { Ecologia, } \\
\text { Genética, } \\
\text { Entomologia }\end{array}$ & 2015 & $\begin{array}{l}\text { Elaine Ferreira } \\
\text { Machado e } \\
\text { Awdry Feisser } \\
\text { Miquelin }\end{array}$ & $\begin{array}{c}\text { A História e a Filosofia } \\
\text { dos estudos } \\
\text { observacionais de } \\
\text { Maria Sibylla Merian } \\
\text { (1647- 1717): } \\
\text { contribuições para a } \\
\text { Biologia e para o } \\
\text { Ensino de Biologia }\end{array}$ & $\begin{array}{c}\text { Apresenta uma síntese } \\
\text { de pesquisa sobre a vida } \\
\text { e obra de Maria Sibylla } \\
\text { Merian (1647-1717) e } \\
\text { suas contribuições para } \\
\text { a biologia em diversas } \\
\text { áreas, analisando } \\
\text { aplicações de atividades } \\
\text { na escola básica. }\end{array}$ \\
\hline 9 & AP & Evolução & 2015 & $\begin{array}{l}\text { Luciana Valéria } \\
\text { Nogueira e } \\
\text { Kelma Cristina } \\
\text { de Freita }\end{array}$ & $\begin{array}{l}\text { Análise de aspectos } \\
\text { da Natureza da } \\
\text { Ciência }(\mathrm{NdC}) \text { e } \\
\text { motivacionais em } \\
\text { estudantes do Ensino } \\
\text { Médio mediada por } \\
\text { sequência didática } \\
\text { centrada na } \\
\text { replicação de } \\
\text { experimentos } \\
\text { históricos darwinianos }\end{array}$ & $\begin{array}{l}\text { Analisa a aplicação de } \\
\text { uma SD centrada na } \\
\text { replicação de } \\
\text { experimentos históricos } \\
\text { feitos por Charles Darwin. }\end{array}$ \\
\hline 10 & PM & $\begin{array}{l}\text { Bioquímica, } \\
\text { Fisiologia } \\
\text { Vegetal }\end{array}$ & 2015 & $\begin{array}{c}\text { Érica Lima } \\
\text { Santos e } \\
\text { Ricardo Santos } \\
\text { do Carmo }\end{array}$ & $\begin{array}{l}\text { Histórias explicativas } \\
\text { para o ensino de } \\
\text { fotossíntese e } \\
\text { abordagem da } \\
\text { natureza da ciência no } \\
\text { ensino médio de } \\
\text { biologia }\end{array}$ & $\begin{array}{l}\text { Investiga o potencial de } \\
\text { narrativas históricas } \\
\text { como recurso para o } \\
\text { ensino de fotossíntese no } \\
\text { ensino médio de biologia. }\end{array}$ \\
\hline 11 & PSD & $\begin{array}{l}\text { Classificação } \\
\text { biológica e } \\
\text { Infectologia }\end{array}$ & 2015 & $\begin{array}{c}\text { Carlos } \\
\text { Aparecido da } \\
\text { Silva Junior, } \\
\text { Letícia Vieira } \\
\text { Basílio, Bruno } \\
\text { Mangili de } \\
\text { Paula } \\
\text { Rodrigues, } \\
\text { Thaís Gimenez } \\
\text { da Silva } \\
\text { Augusto }\end{array}$ & $\begin{array}{l}\text { Inserção da História } \\
\text { da Biologia na } \\
\text { Educação Básica: } \\
\text { produção e análise de } \\
\text { sequências didáticas }\end{array}$ & $\begin{array}{l}\text { Descreve e analisa os } \\
\text { limites e possibilidades } \\
\text { de SDs e materiais } \\
\text { didáticos sobre HC no } \\
\text { ensino de Biologia. }\end{array}$ \\
\hline 12 & PSD & Evolução & 2015 & $\begin{array}{l}\text { Thais Benetti } \\
\text { de Oliveira, } \\
\text { Beatriz } \\
\text { Ceschim e Ana } \\
\text { Maria de } \\
\text { Andrade } \\
\text { Caldeira }\end{array}$ & $\begin{array}{c}\text { Aprendizagem } \\
\text { baseada em } \\
\text { problemas e a } \\
\text { natureza integrada da } \\
\text { Biologia: uma } \\
\text { proposta didática } \\
\text { sobre a evolução } \\
\text { biológica para } \\
\text { Formação Inicial }\end{array}$ & $\begin{array}{l}\text { Propõe atividades } \\
\text { problematizadoras } \\
\text { pautadas na HC sobre a } \\
\text { evolução biológica no } \\
\text { ensino de biologia. }\end{array}$ \\
\hline
\end{tabular}


Quanto aos recursos didáticos, quando se referem a uma proposta de material histórico, se constituem em textos de fontes primárias (textos originais) e secundárias (textos de historiadores da ciência), os artigos 1, 3, 4, 5 e 10 propõem analisar trabalhos de naturalistas ou episódios históricos com potencial para tratamento didático sob a perspectiva da história, filosofia e sociologia da ciência. Entretanto, não se especificavam as estratégias de utilização do material produzido, deixando apenas uma recomendação para seu uso em sala de aula como objeto de estudo, podendo ser trabalhado a partir de leituras e discussões ou como o professor achar mais adequado. Segundo Martins (1998), o estudo de episódios históricos pode permitir que o aluno tenha uma visão mais concreta da real natureza da ciência, conhecendo seus métodos e limitações e percebendo o processo lento e gradativo da construção dos conhecimentos científicos. Os trabalhos de fontes primárias e secundárias ainda podem servir como uma fonte rica de possibilidades, vindo a explicitar as dificuldades dos cientistas na busca pelo conhecimento, o desenvolvimento de suas ideias, formulação de hipóteses e experimentações. Esses textos servem também como uma alternativa às histórias que estão nos livros didáticos, que muitas vezes estão baseadas em uma vertente historiográfica tradicional, reforçando a linearidade do desenvolvimento do conhecimento, omitindo debates e outras questões que direta ou indiretamente, estiveram ligadas no momento de sua formulação (BELTRAN et al., 2016).

Os artigos que consistiam em analisar aplicações de sequências didáticas ou atividades, também utilizavam como recurso, textos históricos originais ou adaptados, sendo que o trabalho 8 também faz uso de imagens e multimídias. As estratégias encontradas foram: Discussões e leituras em todos os trabalhos dessa categoria; aulas práticas nas produções 7 e 9 e também trabalhos em grupo no artigo de número 9.

Já as propostas de atividades ou sequências didáticas tiveram seus recursos mais diversos, sendo que todos utilizavam textos, sejam originais ou de livro didático, $(2,6,11$, 12), filme (2), multimídia $(6,11)$, imagens e confecção de linha do tempo (6). As estratégias encontradas foram em sua maioria leituras e discussões $(2,6,11,12)$ e aulas expositivas dialogadas $(6,11,12)$, seguida por trabalhos e/ou atividades em grupo $(6,11)$ e atividades práticas (11).

Os conteúdos das sequências e atividades dos trabalhos encontrados foram variados, partindo de temas mais comuns ao ensino de Biologia na escola básica como Fisiologia (3 trabalhos), genética (2 trabalhos), Evolução (3 trabalhos), sendo apresentados também temáticas menos usuais como Cronobiologia e Entomologia. Alguns desses assuntos e a maneira com que são desenvolvidos se distinguem do que é apresentado pela maioria dos livros didáticos, que costumam apresentar temas de forma mais abrangente e descontextualizada. A abordagem em $\mathrm{HC}$ por sua vez, possibilita o tratamento de um conteúdo mais específico, porém menos fragmentado e mais contextualizado, visando não somente a aprendizagem de conceitos científicos, mas também a de conteúdos históricos, de investigação científica e Natureza da Ciência (ALLCHIN, 2013).

Quanto ao nível de ensino, sete artigos (1, 4, $6,8,9,10,12)$ apresentam propostas para Ensino Médio e um (7) para Ensino fundamental II; 0 artigo 11 apresenta sequências didáticas para ambos os níveis e três artigos (2, 3, 5) não trazem essa especificação. O fato da maioria dos trabalhos estarem voltados para o ensino médio pode estar relacionado a dificuldade de alguns professores em utilizar História da Ciência no ensino de Ciências à nível fundamental, devido à falta de materiais disponíveis e principalmente porque os livros didáticos costumam introduzir temas com personagens e episódios históricos nas séries finais do ensino fundamental e mais frequentemente no ensino médio.

De maneira geral as propostas objetivavam contribuir para uma formação crítica e reflexiva, acreditando que a abordagem inclusiva de História da Ciência pode facilitar a aprendizagem de conceitos científicos e possibilitar sua integração com os fatores sociais, políticos e históricos envolvidos na construção desse conhecimento. Como resultado das aplicações observou-se o desenvolvimento de uma visão mais crítica da ciência pelos alunos, ao passo em que durante as sequências aspectos de natureza da ciência foram abordados explicitamente.

Concordando com isso, a utilização de sequências didáticas deve continuar sendo enfatizada nesse segmento, já que de acordo com Zabala (1998) ela é um importante 
instrumento para que a aprendizagem possa ser a mais significativa possível, buscando estabelecer relações entre as atividades propostas, aproximando os conteúdos da realidade dos alunos, incentivando a busca pelo conhecimento e também estimulando os alunos a formarem uma visão integrada dos conteúdos a serem trabalhados.

Como visto no Quadro 1, o número de publicações em relação às propostas e aplicações no ensino básico de Biologia ainda é muito pequeno, principalmente quando comparado ao número total de trabalhos apresentados nos eventos. Em artigos que buscaram analisar as produções de teses, dissertações e publicações em periódicos sobre o tema (MOURA et al., 2015; SILVA e GATTI, 2015; AUGUSTO, 2015; PEREIRA e TRIVELATO, 2015), vemos que a grande maioria dos trabalhos é essencialmente teórica, que afirmam a importância de HC no ensino, mas não fornecem subsídios para sua aplicação. Essa falta de trabalhos pode dificultar o trabalho do professor que busca sugestões e materiais sobre a abordagem de HC no ensino.

Contudo sabe-se que muitos desafios podem surgir diante das aplicações, como a formação inadequada dos professores, falta de tempo diante dos programas exigidos pelas escolas e inclusive a escassez de matérias didáticos de boa qualidade sobre a área (SOUZA e PRESTES, 2015). Quanto a isso, os artigos analisados seguiram alternativas que concordam com a proposta de Matthews (1995) para a superação desses obstáculos, sugerindo uma abordagem inclusiva voltada à introdução de episódios históricos nas aulas de ciências e biologia. Essa abordagem mais pontual fornece ao professor autonomia na construção de seu planejamento, podendo incluir diversos materiais didáticos conforme os objetivos previamente estabelecidos e de acordo com o perfil da turma e da escola (PRESTES e CALDEIRA, 2009).

\section{REFERÊNCIAS}

[1] Allchin, D. Teaching the nature of science: perspectives \& resources. Saint Paul (MN): SHiPS Education Press, 2013.

[2] Augusto, T. G. S. O Estado da Arte das pesquisas acadêmicas sobre Ensino de História e Filosofia da Biologia (1983- 2010). X ENPEC, nov 24-27, Águas de Lindóia, SP, 2015. Disponível em:

\section{CONCLUSÃO}

Diante do que foi apresentado concluímos que o número de publicações com propostas ou aplicações relacionadas à $\mathrm{HC}$ no ensino básico de Biologia nos ENPECs ainda é baixo, concordando com outras pesquisas que apresentam um panorama além do encontro analisado. Cinco dos doze artigos selecionados apresentam apenas propostas de materiais com potencial para utilização em sala de aula, não havendo especificações sobre as estratégias de execução, enquanto que quatro trazem análises de efetivas aplicações no ensino de Biologia, e três apresentam propostas de sequências didáticas ou atividades. Embora os trabalhos visem a popularização do tema no ensino, tratando de suas vantagens e limitações, ainda faltam produções com SDs e materiais acessíveis, que podem ser aplicados na escola básica. Esse tipo de trabalho, contendo as dificuldades e contribuições obtidas no processo de ensino-aprendizagem podem motivar o professor que deseja trabalhar com HC no ensino de Biologia.

A maioria dos trabalhos utiliza como recurso didático, textos históricos originais e adaptados, introduzindo episódios históricos aos alunos que a partir de discussões, leituras, trabalhos em grupo e aulas expositivas dialogadas podem vir a construir importantes relações entre os conteúdos científicos e a construção de conhecimentos, como também destacar alguns aspectos essenciais sobre a natureza da ciência. Ressaltamos a necessidade de mais publicações que abordem propostas ou aplicações de atividades e sequências didáticas incluindo $\mathrm{HC}$ no ensino de Biologia, visto sua importância no ensino contextual, vindo a futuramente auxiliar professores que se interessem pelo assunto e buscam materiais de boa qualidade para utilização.

http://www.xenpec.com.br/anais2015/resumos/R02 87-1.PDF> Acesso em: 18 jan. 2017

[3] Beltran, M. H. R; Fumikazu, S. Trindade, L. S. P. História da Ciência: Tópicos atuais 4. São Paulo: Livraria da Física, 2016.

[4] Brasil. Secretaria de Educação Fundamental. Parâmetros Curriculares Nacionais: Ciências Naturais/ Secretaria de Educação Fundamental - Brasília: MEC/SEF, 1998. Disponível em: 
$<$ http://portal.mec.gov.br/seb/arquivos/pdf/ciencias .pdf. > Acesso em 20 out. 2016.

[5] Ministério da Educação. Secretaria da Educação Média e Tecnológica. Parâmetros Curriculares Nacionais + $(\mathrm{PCN}+)$ : Ciências da Natureza e suas Tecnologias. Brasília: MEC, 2002 . Disponível em:< http://portal.mec.gov.br/seb/arquivos/pdf/Ciencias Natureza.pdf> Acesso em: 25 nov. 2016.

[6] Carneiro, M. H. S.; Gastal, M. L. História e filosofia das ciências no ensino de biologia. Ciência \& Educação, v. 11, n. 1, p. 33-39, 2005. Disponível em: < http://www.scielo.br/pdf/ciedu/v11n1/03.pdf $>$ Acesso em 20 nov. 2016

[7] Lederman, N. G. Nature of Science: past, present and future. In: ABELL, S. K. e LEDERMAN, N. G. Handbook of research on science education. Mahwah, NJ: Lorence Earlbaum Associates, 2007. pp. 831-879.

[8] Martins, L.A.C.P. A História da Ciência e o ensino de biologia. Ciência e Ensino, Campinas, v. 5, p. 18-21, dez. 1998. Disponível em: $<$ http://www.educadores. diaadia.pr.gov.br/arquivos /File/fevereiro2013/ciencias_artigos/historia_ciencia .pdf> Acesso em: 13 nov. 2014

[9] Matthews, M. R. Changing the focus: from nature of science to features of science. In: Khine, M. S. (ed.) Advances in nature of science research. Dordretch: Springer, 2012. pp. 3-26. Disponível em: $<$ http://www.bu.edu/hpsscied/files/2012/10/Matthews-HPS-Changing-theFocus-From-Nature-of-Science-to-Features-ofScience.pdf> Acesso em 30 nov. 2016.

[10] Matthews, M. R. História, filosofia e ensino de ciências: a tendência atual e a reaproximação. Caderno catarinense de ensino de física, vol. 12, n. 3, p. 164-214, 1995. Disponível em: < http://link.springer.com/chapter/10.1007/978-94007-2457-0_1\#page-1> Acesso em 30 nov. 2016. [11] Moura, C. B.; AMARAL, P.; NETTO, M.; SCHIFFER, H.; MARQUES, M. A.; GUERRA, A.
Propostas de utilização de História da Ciência em sala de aula: Uma análise em periódicos nacionais. X ENPEC, nov 24-27, Águas de Lindóia, SP, 2015. Disponível em:

http://www.xenpec.com.br/anais2015/resumos/R02 87-1.PDF> Acesso em: 18 jan. 2017

[12] Pereira, M. G.; TRIVELATO, S. L. F. A Natureza da Ciência (NdC) em produções acadêmicas: investigando os anais dos Encontros Nacionais de Ensino de Biologia (2005 - 2014). X ENPEC, nov 24-27, Águas de Lindóia, SP, 2015. Disponível em:

\section{$<$} http://www.xenpec.com.br/anais2015/resumos/R19 47-1.PDF> Acesso em: 18 jan. 2017

[13] Prestes, M. E. B.; CALDEIRA, A. M. A. Introdução. A importância da história da ciência na educação científica. Filosofia e história da biologia, vol. 4, p. 1-16, 2009. Disponível em:<http://www.abfhib.org/FHB/FHB-04/FHB-v040-Maria-Elice-Prestes-Ana-Maria-Caldeira.pdf> Acesso em: 13 out. 2016.

[14] Silva, F. T. O.; GATTI, S. R. T. A pesquisa acadêmica sobre a História e Filosofia da Ciência e a sala de aula: reflexões a partir dos trabalhos apresentados no Encontro de Pesquisa em Ensino de Física (EPEF) entre os anos de 2004 e 2014. X ENPEC, nov 24-27, Águas de Lindóia, SP, 2015. Disponível em: < http://www.xenpec.com.br/anais2015/resumos/R10 82-1.PDF> Acesso em: 18 jan. 2017

[15] Souza, R. A. L.; Prestes, M. E. B. Motivação e emoção no ensino de biologia: análise de sequência didática sobre a viagem de Wallace ao Brasil. Filosofia e História da Biologia, São Paulo, v. 10, n. 2, p. 233-256, 2015. Disponível em: http://www.abfhib.org/FHB/FHB-10-2/FHB-v10-n204.html Acesso em: 21 nov. 2016.

[16] Zabala, A. A prática educativa: como ensinar. Porto Alegre: ArtMed, 1998. 


\section{Gapítulo 10}

\section{PROPOSICÕES DE PROFESSORES ACERCA DA PROBLEMATIZAÇÃO DE TEMAS CIENTÍFICOS POR MEIO DE LIVROS PARADIDÁTICOS E/OU DE DIVULGAÇÃO CIENTÍFICA}

\section{Anelise Grünfeld de Luca}

Sandra Aparecida dos Santos

José Claudio Del Pino

Michelle Câmara Pizzato

Resumo : A problematização de temas científicos por meio da leitura de livros paradidáticos e/ou de divulgação científica (LPDCs), culminando na escrita, pode assumir papel fundamental no processo de ensino e de aprendizagem das Ciências, oportunizando reflexões na elaboração de estratégias explicitadas pelos professores em sala de aula. Os sujeitos desta pesquisa foram 21 professores de Biologia e Química, participantes de duas oficinas, realizadas em dois eventos: VI ENEBIO e 36ํㅡㄹ EDEQ, em outubro de 2016. Intencionou-se compreender as percepções sobre o uso dos LPDCs em sala de aula; como instrumento de coleta de dados, aplicou-se um questionário (antes e depois da oficina), estruturado com perguntas fechadas, mensuradas através da escala Likert e cinco questões abertas. A tabulação e análise dos dados, resultaram nas seguintes categorias: 0 LPDC como complementação do livro didático; o LPDC como possibilidade de desenvolver a alfabetização científica e a interdisciplinaridade. 


\section{INTRODUÇÃO}

Os livros de divulgação científica têm sido utilizados comumente na sala de aula por professores das áreas das ciências, na intenção de favorecer os entendimentos dos conteúdos conceituais, promovendo o aprendizado dos estudantes. Além de considerar as práticas de leitura e as expectativas sobre o desenvolvimento da criatividade, da escrita e da interação com outras linguagens que não a do livro didático.

Entretanto, Almeida (2015), discute sobre as possibilidades e os limites do uso dos textos de divulgação científica em sala de aula, apresentando critérios necessários para adotá-los como recurso didático. E nesse ínterim, Almeida (2015), afirma que se faz necessária, a reflexão sobre os objetivos do ensino, a escola básica não forma cientistas, mas deve se preocupar com o acesso da população à cultura científica. Ainda Gouvêa (2015, p.14) destaca "[...] a importância de se inserir na formação inicial e continuada de professores a problematização sobre as questões que envolvem o uso em sala de aula de textos elaborados no contexto de divulgação e da técnica".

Coadunamos com o conceito de divulgação científica apresentado por Gouvêa (2015, p.13) como "[...] uma prática social materializada em discursos gravados em diferentes suportes e que circulam nas escolas". Considerando que a prática social para permanecer, precisa ser divulgada por aqueles que a acreditam como função social. E então é necessário alfabetizar os não praticantes da ciência e da tecnologia como forma de consumir, utilizar e decidir sobre questões envolvendo a ciência (GOUVÊA, 2015).

Acreditamos que os textos de divulgação científica podem promover a alfabetização científica enquanto se propõem a construir imagens mais reais sobre a ciência, permitindo a discussão sobre a natureza da linguagem utilizada, possibilitando diferentes interpretações, mediadas pelos debates em sala de aula, onde professores e estudantes podem expressar e apresentar suas posições em relação as suas interpretações.

Cachapuz et al (2005) apresentam o texto "A importância da Educação Científica na Sociedade Atual", explicitando a contribuição da alfabetização científica para formação de cidadãos, principalmente na defesa do mínimo de conhecimentos específicos, acessíveis a todos, que possam orientar a tomada de decisões, no sentido da participação em debates de problemas reais, que envolvem a vida cotidiana. E neste contexto afirmam que

[...] a aprendizagem das ciências pode e deve ser também uma aventura potenciadora do espírito crítico no sentido mais profundo: a aventura que supõe enfrentar problemas abertos, participar na tentativa de construção de soluções...a aventura, em definitivo, de fazer ciência (CACHAPUZ et al., 2005, p. 30).

A alfabetização científica, conforme Bybee (1994, apud Sasseron e Carvalho, 2011), pode ser entendida em três dimensões: funcional, conceitual e procedimental, multidimensional, estas se centram nos processos de incorporação de conhecimento científico em situações de sala de aula. Neste aspecto pode se pensar em um Ensino de Ciências desenvolvido a partir de atividades problematizadoras; com temáticas que relacionam e conciliam diferentes áreas e esferas da vida.

Lopes e Dulac (1999) apresentam o texto "Ideias e palavras na/da ciência ou leitura e escrita: o que a ciência tem a ver com isso?", destacando a leitura e a escrita como práticas sociais e culturais, em que a atividade de ler e escrever inicialmente parece vazia, mas aos poucos é preenchida pelas leituras de mundo, que cada leitor constrói através de cada ciência, sendo um compromisso de todas áreas. Então afirmam que "[...] a linguagem escrita pode ser considerada como um dos meios mais eficazes através dos quais a ciência constitui-se e constrói realidades" (LOPES; DULAC, 1999, p. 38).

As atividades de leitura e escrita são habilidades fundamentais, pois são elementos centrados nos processos de incorporação de conhecimento do "fazer científico". Através da leitura e escrita de textos de divulgação científica pode-se promover a compreensão básica de termos, conhecimentos e conceitos científicos fundamentais; a compreensão da natureza das ciências, dos fatores éticos e políticos que circundam sua prática e o entendimento das relações existentes entre ciência, tecnologia, sociedade e ambiente, desde que pensados seus objetivos no ensino. 
Considerando o que foi apresentado, os objetivos deste trabalho estão pautados em: refletir e discutir o papel que a leitura e a escrita podem assumir no processo de ensino e de aprendizagem das Ciências, em particular da Química e da Biologia, oportunizando reflexões acerca da leitura e da escrita na elaboração de estratégias viabilizadas pelos professores em sala de aula, a partir de textos dos livros paradidáticos e/ou de divulgação científica.

\section{CAMINHOS PERCORRIDOS}

O presente trabalho tem como proposição metodológica uma abordagem quantitativa e qualitativa. Os sujeitos desta pesquisa foram 21 professores de Biologia e Química, participantes de duas oficinas intituladas: "Estratégias Didáticas Interdisciplinares: a leitura e a escrita a partir de livros paradidáticos e/ou de divulgação científica em sala de aula", realizada no VI ENEBIO (Encontro Nacional do Ensino de Biologia) nos dias 3 a 6 outubro de 2016, em Maringá e "Práticas Interdisciplinares na Promoção da Leitura e da Escrita a partir de livros paradidáticos e/ou de divulgação científica: diálogos entre a Química e a Biologia em sala de aula" no 36으르 (Encontro de Debates sobre o Ensino de Química), 14 e 15 de outubro de 2016, em Pelotas.

A intenção foi discutir as proposições sobre o uso dos livros paradidáticos e/ou de divulgação científica na sala de aula, identificando seu uso ou não, pelos professores. Como instrumento de coleta de dados, foi aplicado um questionário, estruturado com perguntas fechadas, mensuradas através da escala Likert e cinco questões abertas, referentes ao uso ou não dos livros paradidáticos e/ou de divulgação científica, as estratégias utilizadas e a importância da leitura e escrita nas aulas de ciências, considerando a possibilidade de favorecer a aprendizagem dos conteúdos conceituais e fomentar discussões quanto à contextualização desses conceitos; além de promover a leitura e a escrita na intenção de que os estudantes assumam o papel de sujeitos ativos e qualificados nas interações sociais.

A aplicação do questionário deu-se antes da abordagem da oficina e ao seu término (somente as proposições da escala Likert e a questão 6), buscando encontrar por comparação o que os participantes perceberam sobre a abordagem e quais proposições foram modificadas a partir das discussões desenvolvidas na mesma. A escala Likert, propõe que cada item deve ser avaliado de preferência por meio de cinco opções. Com o intuito de gerar uma medida quantificada para os indicadores, empregaram-se valores de 1 a 5 da seguinte maneira: valor 1 - quando a pessoa discorda totalmente da afirmação apresentada; valor 2 - quando discorda parcialmente; valor 3 quando é indiferente frente à afirmação; valor 4 - quando concorda parcialmente e; valor 5 - quando concorda totalmente. As proposições na escala Likert e as questões abertas que foram aplicadas estão apresentadas nos resultados e discussão dos mesmos.

Inicialmente foi abordada a questão de ler e escrever, enfatizando a leitura e a escrita como práticas sociais e culturais, habilidades que se ensinam e se aprendem e considerando que a ciência escolar deve possibilitar a ampliação da leitura de mundo. Em seguida, foi apresentada e discutida a questão da alfabetização científica, enquanto pluralidade semântica pode ser entendida como letramento, alfabetização e enculturação com o objetivo da formação cidadã, domínio e uso dos conhecimentos científicos.

Ainda foram explicitadas estratégias para o uso de livros paradidático e/ou de divulgação científica: diário de leitura; produção de imagens/desenhos; roteiros; discussão em um blog; leitura coletiva e/ou individual; apresentação de seminários; produção de textos; atividades práticas; pesquisa de opinião; releituras; teatralização e elaboração de história em quadrinhos.

$\mathrm{Na}$ sequência, em grupos, os participantes realizaram a leitura de textos diversos, encontrados nas seguintes obras: Gaarder (2001), Schwarcz (2008, 2009), Standage (2005), Kean (2011), Le Couteur; Burreson (2006), Emsley (2006), Fisher (2004), Wolke (2003, 2005), entre outros.

Discutiram, registraram e socializaram ideias e possibilidades da utilização dos livros paradidáticos e/ou de divulgação científica em sala de aula. Ao término da oficina, foi aplicado novamente o questionário, somente com as proposições da escala Likert e a sexta questão. 


\section{RESULTADOS E DISCUSSÃO}

A partir da tabulação e da análise dos dados coletados, foi possível organizar três categorias: o livro paradidático e/ou de divulgação científica como complementação do livro didático relacionada com as proposições (1 e 3); a utilização de livros paradidáticos e/ou de divulgação científica enquanto possibilidades de desenvolver a alfabetização científica, proposições (2, 4 e 6) e a utilização de livros paradidáticos e/ou de divulgação científica proporcionando a interdisciplinaridade referente às proposições (5, 7 e 8), ratificadas nas respostas das questões abertas.

\section{O LIVRO PARADIDÁTICO E/OU DE DIVULGAÇÃO CIENTÍFICA COMO COMPLEMENTAÇÃO DO LIVRO DIDÁTICO}

Considerando a proposição 1: 0 livro paradidático sempre complementa o livro didático, uma vez que trata os conceitos das ciências da mesma forma, considerando as informações e a estrutura textual, percebe-se que esta proposição teve um grau de concordância alto, o que nos remete para o cuidado com os erros conceituais que podem estar presentes nos textos, como bem explicita Ferreira e Queiroz (2015, p. 132), "É necessário atentar, porém, para a ocorrência de erros conceituais e simplificações [...]" as mesmas autoras complementam que "[...] o seu uso requer uma preparação adequada dos professores para que possam explorá-las apropriadamente."

Quanto a proposição 3: A utilização de livros paradidáticos é sempre complementar, considerando que muitos professores não os utilizam, o grau de concordância foi menor comparado a proposição 1, observa-se que o uso dos livros paradidáticos nem sempre ocorre pelos professores, este fato pode apontar a ausência de discussões e de abordagens nos cursos de formação de professores, do uso dos livros paradidáticos como recurso didático, favorecendo a leitura e a escrita. Em uma das respostas a professora, identificada por P1, justifica o não uso:

[...] falta tempo na carga horária e minha escola não dispõe deste tipo de obra Trabalho com EJA e alunos de baixa renda que não dispõem de recursos financeiros para adquiri-los e de pouco tempo para a leitura em sala e em casa. P1
5. A UTILIZAÇÃO DE LIVROS PARADIDÁTICOS E/OU DE DIVULGAÇÃO CIENTÍFICA ENQUANTO POSSIBILIDADES DE DESENVOLVER A ALFABETIZAÇÃO CIENTÍFICA

A proposição 2: A leitura do livro didático e de um possível livro paradidático é suficiente para subsidiar a construção de um conceito das ciências, explicitando que nem um e nem outro dão conta da construção dos conceitos. O grau de concordância apresentado foi baixo, demonstrando que para os participantes, os livros paradidáticos assumem a função de recurso que pode subsidiar a formação dos conceitos, enquanto promovem a leitura e a discussão de aspectos pontuais da ciência.

Em se tratando de divulgação da ciência, a proposição 4: A divulgação da ciência pode acontecer por variados meios de comunicação, inclusive por livros paradidáticos, teve um grau de concordância alto, 0 que evidencia que para os participantes, os livros paradidáticos podem apresentar textos de divulgação científica, mas há que se ter o cuidado na seleção destes materiais. Almeida (2015, p. 61) atenta para este fato "[...] a necessidade de selecionar que divulgação utilizar".

A utilização de livros paradidáticos favorece a alfabetização científica é a proposição 6 , que também obteve um grau de concordância alto. Na questão 4 os professores, quando questionados, consideram importante trabalhar com a leitura e a escrita em sala de aula, a maioria respondeu positivamente e algumas percepções consideradas na resposta da professora P2 "[...] acredito que é papel de todos os professores trabalharem a alfabetização e o letramento de seus alunos". Para a professora P3 "[...] através da leitura e da escrita os estudantes ampliam seu vocabulário, aumentam sua capacidade de argumentação e promove a criatividade". E ainda a professora P4 "[...] é uma atividade que engloba, e é necessária em todas as áreas do conhecimento, na construção e compartilhamento deste e em todos os setores e processos sociais".

Sasseron e Carvalho, (2011, p.75) destacam em seu artigo "Alfabetização Científica: uma revisão bibliográfica", a pluralidade semântica que permeia a nomenclatura atribuída a alfabetização científica que em geral objetiva "[...] a vida em sociedade, levando em conta sua atuação cidadã, crítica e responsável". 
Considerando esses pressupostos, trabalhar com textos de livros paradidáticos e/ou de divulgação científica pode fomentar discussões que envolvem aspectos do saber, fazer e usar a ciência, mas sempre encarado com um recurso didático considerando os objetivos propostos pelo professor.

\section{A UTILIZAÇÃO DE LIVROS PARADIDÁTICOS E/OU DE DIVULGAÇÃO CIENTÍFICA PROPORCIONANDO A INTERDISCIPLINARIDADE}

Considerando que a utilização de livros paradidáticos favorece a leitura e a escrita, a proposição 7: O compromisso da leitura e da escrita é papel de todas as áreas, tendo em vista as diversas linguagens que cada área do conhecimento apresenta, obteve um grau de concordância alta, revelando na opinião dos participantes, que todas as áreas do conhecimento fazem uso das linguagens específicas e portanto, necessitam de leitura e de escrita como formas de comunicação e de aprendizagem dos conceitos. Desta forma, a interdisciplinaridade é proporcionada, proposição 8: A utilização de livros paradidáticos proporciona a interdisciplinaridade, pois quando se abordam fenômenos envolvendo os conceitos de uma ciência, por si só necessitam dos conceitos de outra área para sua compreensão. Os professores expressaram esta ideia nas respostas das questões abertas:

[...] considero essas habilidades importantes e precisam ser desenvolvidas em todas as disciplinas. Em Biologia e Ciências é importante que o aluno entre em contato e se familiarize com a leitura e a escrita científica. P5

[...] em todas as áreas é importante a leitura e a escrita, embora cada área do conhecimento de ciências tenha uma linguagem específica elas demandam de leituras, pesquisas, teorias, conceitos que podem ser expressados pela escrita, principalmente saber o que o aluno está pensando. P6

A partir da leitura dos textos dos livros paradidáticos e/ou de divulgação científica dispostos aos professores, das discussões realizadas, dos registros e socialização, encontram-se a seguir duas proposições conceituais para a sala de aula elaboradas pelos participantes, proposta 1 do livro: História do mundo em 6 copos - Tom Standage e proposta 2, do livro: Ei tem alguém aí? Jostein Gaarder.

Tabela 3: Proposições para sala de aula.

Proposta 1 - História do mundo em 6 copos

- Discussão sobre Remédios falsos (não testados)

- Utilização/comércio e perigos envolvidos

- Discussão sobre a coca planta

- Propriedades medicinais

- Propriedades botânicas

- Estrutura molecular do princípio ativo

- Discussão sobre o efeito das drogas estimulantes - cocaína

- Discussão sobre o processo histórico de industrialização no mundo

- Meio ambiente - relações da produção em grande escala, misturas, densidade, estruturas, extração de princípios ativos, a importância do marketing na venda de produtos.

\section{Proposta 2 - Ei! Tem alguém aí?}

- Astronomia: Terra (localização) astros luminosos e iluminados, características que favorecem a vida (fatores abióticos e bióticos)

- Características gerais dos seres vivos: ciclo de vida, reprodução, evolução.

- Classificação dos seres vivos

- Nomenclatura binominal

- Conteúdos atitudinais: educação, respeito pelo outro e ao diferente (diferença de gêneros). 


\section{CONSIDERAÇÕES FINAIS}

A oficina desenvolvida foi elaborada a partir das inquietações percebidas pelos autores na utilização de livros paradidáticos e/ou de divulgação científica em aulas de ciências, especialmente de Química e Biologia. As abordagens e discussões oportunizadas corroboraram para as impressões iniciais; a leitura dos textos apresentados tornam os conceitos científicos interessantes e contextualizados, envolvendo os leitores na relação dialógica com os respectivos autores.

O uso de livros paradidáticos e/ou de divulgação científica nas aulas curriculares contribui interdisciplinarmente com momentos que se tornam potenciais para a compreensão de sujeitos e fenômenos

\section{REFERÊNCIAS}

[1]Almeida, M. J. P. M. de. Divulgação Científica no ensino Escolar: possibilidades e limites. IN: Giordan, Marcelo; CUNHA, Marcia Borin da (orgs). Divulgação Científica na Sala de Aula. Ijuí: Ed. UNIJUÍ, 2015.

[2]Cachapuz, A., Gil-Perez, D., Carvalho, A. M. P. de, PRAIA, J., VILCHES, A. (orgs.) A necessária Renovação do ensino de ciências. São Paulo: Ed. Cortez, 2005.

[3]Emsley, J. Vaidade, vitalidade, virilidade: a ciência por trás dos produtos que você adora consumir. Rio de Janeiro: Jorge Zahar, 2006.

[4]Ferreira, L. N. de A.; Queiroz, S. L.. Utilização de textos de divulgação científica em sala de aula de química. IN: GIORDAN, M.; CUNHA, M. B. da (orgs). Divulgação Científica na Sala de Aula. Ijuí: Ed. UNIJUÍ, 2015.

[5]Fischer, L. A ciência no cotidiano: como aproveitar a ciência nas atividades do dia-a-dia. Rio de Janeiro: Jorge Zahar Ed., 2004.

[6]Gaarder, J. Ei! Tem alguém aí? São Paulo: Companhia das Letrinhas, 2001.

[7]Kean, S. A colher que desaparece: e outras histórias reais de loucura, amor e morte a partir dos elementos químicos. Rio de Janeiro: Zahar, 2011. [16] cotidianos. A escrita escolarizada evidencia o discurso científico em gêneros textuais específicos da coleta de dados que emerge da interpretação dos textos lidos e em gêneros textuais diversos que estão inseridos na comunicação do mundo, além da escola, como propagandas, notícias, símbolos de indicação e sinalização, entre outros.

Os processos de ensino e de aprendizagem necessitam reflexão qualificada por parte dos professores que incorporam determinadas estratégias metodológicas a partir de suas epistemes; daí a importância de a leitura e a escrita serem processos que precisam orbitar a formação inicial e continuada dos docentes.

[8]Le Conteur, P., Burreson, J. Os botões de napoleão: as 17 moléculas que mudaram a história. Rio de Janeiro: Jorge Zahar Ed., 2006.

[9]Neves, I. C. B., Souza, J. V., Schäffer, N., Guedes, P. C., Klüsener, R. (orgs). Ler e escrever: compromisso de todas áreas. 2 ed. Porto Alegre: ED. da Universidade UFGRS, 1999.

[10] Sasseron, L. M.; Carvalho, A. M. P. de. Alfabetização Científica: uma revisão bibliográfica. Investigações em Ensino de Ciências, v16(1), p. 59-77, 2011.

[11] Schwarcz, J. Barbies, bambolês e bolas de bilhar: 67 deliciosos comentários sobre a fascinante química do dia-a-dia. Rio de Janeiro: Jorge Zahar Ed., 2009.

[12] Uma maça por dia: Mitos e verdades sobre os alimentos que comemos. Rio de Janeiro: Jorge Zahar Ed., 2008.

[13] Standage, T. História do mundo em 6 copos. Rio de Janeiro: Jorge Zahar Ed., 2005.

[14] Wolke, R. L. O que Einstein disse a seu cozinheiro: a ciência na cozinha (inclui receitas). Rio de Janeiro: Jorge Zahar Ed., 2003.

[15] O que Einstein disse a seu cozinheiro, 2: mais ciência na cozinha. Rio de Janeiro: Jorge Zahar Ed., 2005. 


\section{Bapítulo 11}

\section{LEI No 13.146, DE 6 DE JULHO DE 2015: UMA LEITURA}

\section{Veronica Ribeiro da Silva Cordovil \\ Marcela Arantes Ribeiro}

Resumo: Este artigo apresenta uma reflexão sobre a Lei ㄲo 13.146, de 06 de julho de 2015, que institui a Lei Brasileira de Inclusão da Pessoa com Deficiência (Estatuto da Pessoa com Deficiência). Diante dessa nova legislação apresenta como problemática: Por que ainda discutimos a exclusão e inclusão? Como compreender o Direto à Educação na legislação? A partir dos questionamentos direciona-se o objetivo principal a partir da necessidade de conhecer e discutir a Lei do Estatuto da Pessoa com Deficiência, entendendo a necessidade de divulgar em todos os meios de discussão a ideia de que é necessário conhecer e respeitar as diversidades socioculturais da humanidade. O desdobramento do objetivo geral constrói-se os específicos que nortearam a construção desse trabalho, sendo eles: identificar as propostas da Lei no que tange ao Direito à Educação e demonstrar a sua aplicabilidade aos assegurados do sistema educacional inclusivo. Realizou-se uma pesquisa bibliográfica, onde o material objeto de estudo foi o Estatuto da Pessoa com deficiência, selecionado o Capítulo IV, do direito à educação, art. 27, 28 e 30, considera-se que o Art. 29 foi vetado, sob o qual foi realizada uma abordagem qualitativa. Surgiram as seguintes discussões: exclusão e inclusão, um tema atual; o Direito à Educação na Constituição Federal e na Lei ํo 13.146/2015, bem com a sua aplicabilidade.

Palavras Chave: Educação. Legislação. Inclusão. 


\section{INTRODUÇÃO}

Este artigo apresenta uma reflexão sobre o Estatuto da Pessoa com Deficiência, Lei $\mathrm{n}$ ㅇ 13.146, de 06 de julho de 2015, o qual institui a Lei Brasileira de Inclusão da Pessoa com Deficiência e o objetivo principal é conhecer sua abrangência e aplicabilidade no âmbito educacional, entendendo a necessidade de melhor divulgar a ideia de que é necessário conhecer e respeitar as diversidades.

Assim, apresenta-se uma discussão onde a ideia de diversidade está ligada a compreensão de pluralidade, multiplicidade, diferentes ângulos de visão ou de abordagem, onde trata das diferentes condições físicas, sensoriais e socioeconômicas, origens, etnias, gênero, crenças, classes sociais, contexto sociocultural no âmbito da Lei no 13.146/2015.

Percebe-se a importância de discutir, interpretar e analisar a Lei no 13.146/2015 como um novo instrumento que perpassa e modifica as relações sociais. Por isso, o tema merece debates e aprofundamentos, na busca de alternativas que possibilitem a equiparação de oportunidades a todos, onde - discurso a alinha-se com a prática mediante as concepções teóricas e legais que orienta a ação de todos os profissionais da Educação.

A seleção do tema ocorreu em virtude da importância dessa discussão para que as pessoas percebam que, mesmo sendo diferentes uns dos outros, cada pessoa possui características e qualidades singulares e importantes, as quais os tornam únicos e, por isso, todos devem ser respeitados e valorizados, como também respeitar e valorizar o outro.

Para a escolha da temática considerou-se também a experiência profissional das autoras na Ciência da Educação, situação que favoreceu a análise e interpretação dos dados.

O texto está ancorado nos seguintes questionamentos: a) Quais as formas de exclusão e como superá-las a partir da compreensão da necessidade social de se ter uma educação inclusiva? O que propõe a Constituição Federal e a Lei no 13.146/2015 no que tange ao direito à Educação? c) Como a Lei pode ser aplicada aos assegurados do sistema educacional inclusivo em todos os níveis e aprendizado ao longo da vida? $E$, por fim, de quem é a responsabilidade no que se refere à Lei no 13.146/2015?

A estrutura textual se desenvolve a partir da discussão entre os temas exclusão e inclusão, a questão do Direito à Educação na Constitucional Federal e na Lei no 13.146, de 06 de julho de 2015, e a sua aplicabilidade, considera-se ainda que a discussão que perpassa sobre a Educação remete a compreensão da sociedade, da cultura e história que se vive atualmente. Pois, o ser humano produz e transforma continuamente a cultura que movimenta as relações sociais e constitui a história do povo.

A educação pode ser compreendida como um processo contínuo de partilha, de socialização da cultura, de construção e reconstrução da percepção e valores da humanidade, enfatiza-se que as instituições de ensino, tanto do ensino básico como o superior, conduz uma socialização sistematizada, organizada da cultura e compreensão dos indivíduos que fazem parte da sociedade.

\section{EXCLUSÃO X INCLUSÃO: UMA DISCUSSÃO ATUAL}

A exclusão pode designar desigualdade social, miséria, injustiça, exploração social e econômica, marginalização social, entre outras significações e está ligada aos fatores históricos de segregação, marginalização, abandono e tortura.

A humanidade está em constante modificação. Do princípio biológico, fisiológico, sem dúvida que há características do humano que são comuns a todos. Contudo, não pode-se falar em natureza humana sem articular esta natureza a uma condição humana, condição que é construídas pelos indevidos que fazer parte da sociedade, os valores e conceitos são construídos, logo estão passíveis de mudanças.

Nessa perspectiva, compreende-se que os problemas sociais e as dificuldades conduzem a formação de grupos sociais uns isolados dos outros, onde aqueles com menos oportunidades tendem a se tornar a margem do outro grupo, caracterizando o percurso da marginalização social. Assim, pode-se compreender exclusão como: 
[...] coleções de indivíduos separados de seus pertencimentos coletivos, entregues a si próprios, e que acumulam a maior parte das desvantagens sociais: pobreza, ausência de trabalho, sociabilidade restrita, condições precárias de moradia, grande exposição a todos os riscos de existência etc. (apud BONET, 2005, p. 02).

Conforme aponta o autor, a exclusão social corresponde a todas as pessoas que dependem de si próprio para sobreviver e são separadas das oportunidades e condições de sobreviver que são oferecidas a todos (coletivo), o que pode levar a condição social de pobreza, a precariedade de moradia, saúde e educação, além de estarem em desvantagem no mercado de trabalho e restrição social.

A superação destes fatores históricos de exclusão perpassa pela discussão do anverso, ou seja, o de compreender a inclusão a partir da necessidade social de se romper com as formas de exclusão de qualquer natureza e em qualquer situação ou ambiente social, consolidando ações que alcancem toda a sociedade.

Dessa forma, antes de pensar a inclusão escolar deve-se pensar a inclusão social, pois essa contempla a inclusão escolar a partir do momento que se compreende que a escola é prestadora de serviço à sociedade e, principalmente, formadora de cidadãos.

Diante disso, se faz necessário construir e reconstruir o ensino considerando a diferença e a diversidade no ambiente escolar.

É importante enfatizar que a sociedade, através dos processos de reconhecimento de identificação e diferenciação, constrói os contornos demarcadores das fronteiras entre aqueles que representam o dito normal/saudável e aqueles que representam o dito anormal/diferente. (SANTOS, 2010, p. 36).

O autor enfatiza a influência da sociedade na construção das identificações das pessoas a partir do momento que se constrói o reconhecimento daqueles que fazem parte do grupo social, incluindo ou excluindo pessoas. Diante disso, Klein (2010, p.15) aborda a importância da escola inclusiva,

Colocando o foco na escola, quando penso a inclusão referimo-nos a toda e qualquer posição de aprendizagem e de aluno criada a partir das relações que são estabelecidas naquele espaço.

$\mathrm{Na}$ escola inclusiva tem-se a valorização das habilidades do aluno diante da construção do conhecimento, considerando as relações interpessoais construídas na sala de aula. Por isso, a importância da inclusão social, tornando-se como responsabilidade da escola o ensino aprendizagem de todos dos alunos.

Outro ponto fundamental para o desenvolvimento do ensino aprendizagem de todos os alunos perpassa pela realização do levantamento das principais dificuldades apresentadas pelos alunos das escolas. Tal ação poderá ocorrer pelo mapeamento utilizado como um instrumento norteador do trabalho didático. Pois,

\section{a falta de sondagem e diagnóstico, muitas vezes propõe ou o que é impossível alcançar, ou o que não interessa, ou até o que já foi alcançado. O conhecimento da realidade sempre será um dos critérios principais para a elaboração de todo planejamento. (SCHMITZ, 1993, p.105).}

Percebe-se que tais mapeamentos permitiram um "diagnóstico" prévio (retrato) das turmas atendidas, possibilitando acompanhar a evolução dos alunos, além de fornecer subsídios para o planejamento de atividades que serão desenvolvidas e, posteriormente avaliar as mudanças produzidas por todos os alunos e adequar ao nível de conhecimento das turmas.

Para garantir este papel da instituição de ensino, o Ministério da Educação vem desenvolvendo uma Política Nacional de atendimento à diversidade humana em articulação com os sistemas públicos de ensino. Nesse sentido, ampliou os debates sobre áreas definidas pela Lei no 9.394/1996 - LDB como modalidades e elaborou diretrizes nacionais a fim de que 
- princípio da diversidade se fizesse presente nos projetos políticos pedagógicos das instituições, nas áreas de educação ambiental, educação em direitos humanos, educação especial, educação do campo, educação escolar indígena, quilombola e educação para as relações étnico-raciais, com vistas ao desenvolvimento de sistemas educacionais inclusivos. (BRASIL, 2013, p.10).

Assim, todas as instituições de ensino é lugar de processo e prática que se concretizam nas relações sociais, tendo em vista os diferentes sujeitos que a demandam e a educação consiste no processo de socialização da cultura da vida, no qual se constroem, se mantêm e se transformam saberes, conhecimentos e valores, incluindo as discussões e ações sobre a diversidade e inclusão social.

Evidencia-se, que na educação, a inclusão entra em discussão a partir do compromisso da educação para todos que teve maior importância a partir de 1994, com a Declaração de Salamanca, que oficializou o termo inclusão no campo educacional; o termo necessidades especiais; uma proposta pedagógica definindo como público alvo alunos com deficiência, transtornos globais de desenvolvimento, altas habilidades e superdotação; a necessidade de atendimento especializado para as pessoas com deficiências, reconhecendo as necessidades e as urgências da educação para crianças, jovens e adultos com necessidades especiais, dentro do sistema regular de ensino.

Desse modo, no que diz respeito às escolas, as crianças com necessidades especiais devem ser incluídas no ensino regular, e este precisa ser revisto com objetivo de atender as necessidades individuais de cada aluno.

Assim, parte-se do princípio de que a inclusão abarca todas as crianças com necessidades especiais ou não, convivendo entre si. Logo, no campo pedagógico, a inclusão integra e socializa a criança, possibilitando o desenvolvimento em conjunto, gerando igualdade de oportunidades sustentada pelo respeito às diferenças e diversidades sociocultural. Nesse sentido, Stainback (1999, p. 21) afirma que "o ensino inclusivo é a prática de todos independente de seu talento, deficiência, origem socioeconômica ou origem cultural em escolas e salas de aula provedoras, onde todas as necessidades dos alunos são satisfeitas."

Dessa forma, compreende-se que a ação de educação para a inclusão envolve o trabalho de todos internamente e externamente à escola, envolvendo diretamente a participação da família no processo de inclusão, tanto educacional como social.

A socialização/interação da família com a comunidade e escola gera aproximação da escola e o espaço social na qual os alunos vivem e constitui um papel de muita importância para o desenvolvimento da consciência de cidadania e de direitos, uma vez que "a ampla e consciente introdução de um indivíduo no mundo objetivo de uma sociedade ou de um setor dela" (BEGER e LUCKMANN, 2002, p. 175).

Assim, compreendendo que a partir da cidadania possibilita a participação ativa de todos os indivíduos na sociedade. A interação social torna-se fundamental para as ações de igualdade social, não há cidadania plena se não houver a possibilidade de convivência com o outros e suas diferenças.

Nesse sentido, e interligando a inclusão social, Mittler (2003, p.36), afirma, "a rua de acesso à inclusão não tem um fim porque ela é, em sua essência, mais um processo do que um destino". Compreende-se então que a inclusão inicia-se com uma mudança na sociedade, percebe-se que essa é caracterizada como um processo, uma vez que a inclusão pode ser compreendia como uma conquista social e sendo a sociedade dinâmica está sujeita as constantes alterações.

Partindo do princípio de que a sociedade está em constante mudança, a educação deve acompanhar tal mudança, por isso educação inclusiva exige uma formação mais ampla de seus profissionais, haja vista que essa nova atuação necessita de um apoio específico levando em consideração a especificidade de cada aluno, contribuindo para afirmação das diferenças.

Por isso, compreende-se que ao discutir educação inclusiva, corresponde tanto formação dos professores, com ações desenvolvidas dentro e fora da sala de aula, de modo a refletir sobre a prática pedagógica e a necessidade de mudança no Sistema Educacional objetivando a construção de uma escola inclusiva. 
Segundo Ferreira (2006, p.31) afirma que:

\begin{abstract}
A aula inclusiva visa responder à diversidade de estilos de aprendizagem na sala de aula; então, qualquer ação de desenvolvimento e aperfeiçoamento de práticas de ensino e aprendizagem de professores para a inclusão deve ajudálos a refletir sobre formas de levantamento de informações sobre seu/sua/s aluno (a)s e planejamento de diversas atividades que abranjam os estilos de aprendizagem individual.
\end{abstract}

Com capacitação dos profissionais torna-se possível conduzir o ensino a partir uma aula inclusiva atendendo as necessidades de cada aluno com base nas suas habilidades, para tanto o professor fará uso de práticas didáticas que envolvam diretamente 0 processo de ensino aprendizagem dos alunos, direcionando para reflexão de como ensinar, o que deve ensinar e o por que ensinar.

Por isso, para a consolidação da educação inclusiva deve haver uma mudança estrutural na escola, desde capacitação aos professores à mudança de práticas didáticas de ensino com aplicação do Plano de aula/intervenção nas turmas com acompanhamento do supervisor e avaliação enfocando o respeito à aprendizagem dos alunos compreendo e questionando o mundo em que vive.

A escola inclusiva é um dos espaços para construção da cidadania, a família é o primeiro espaço onde a criança constrói em sua vivência valores e a comunidade e outro espaço onde esses valores se desenvolvem. É na escola onde as crianças e os adolescentes começam a conviver em grupo social diversificado, fora do contexto familiar.

Dessa forma, como abordada na Declaração de Salamanca (1994), nós devemos pensar uma proposta de educação para paz, onde buscam sensibilizar os alunos, para novas formas de convivências baseadas na solidariedade e respeito às diferenças, valores os quais conscientizam os cidadãos de direitos e deveres sensíveis para rejeitarem a opressão e a violência. $\begin{array}{ll}3 . & \text { DOS } \\ \text { METODOLÓGICOS }\end{array}$

Para abordagem dos problemas apresentados fundamenta-se a discussão nos princípios constitucionais brasileiro, de direitos e igualdades, a partir da compreensão de inclusão apresentada por Bonetti (2005), Ferreira (2006) e Mittler (2003), onde a discussão sobre inclusão envolve o processo sociocultural da sociedade brasileira. Dessa forma, antes de pensar a inclusão no âmbito escolar, deve-se pensar a inclusão em uma escala social, para posteriormente discuti-la nos espaços escolares. Diante disso, se faz necessário construir e reconstruir o ensino considerando a diferença e a diversidade social.

Optou pela pesquisa exploratória, junto com a pesquisa interpretativa. Considerando Gil (2002, p. 41) sobre a pesquisa exploratória que "tem como objetivo proporcionar maior familiaridade com o problema, com intenção de torná-lo mais explícito ou a constituir hipóteses". Assim, realizou uma pesquisa que tem por objetivo principal o aprimoramento de ideias ou a descoberta de intuições, no que tange o direito de todos à Educação.

Optou-se, também, pela pesquisa interpretativa que segundo Ludke e André (2001, p. 11/13) afirma que "por um lado, é atraída a uma sensibilidade geral, interpretativa, e, por outro, por concepções da experiência humana e de sua análise mais restrita a uma visão humanista". Intercalando a sensibilidade com a experiência do pesquisador(a) tem-se a construção da intersubjetividade na construção de dados, através da interação entre o pesquisador e o objeto pesquisado. Logo, construiu-se um texto estimulando uma postura de respeito, e reconhecimento dos direitos e igualdades na sociedade brasileira.

Com a finalidade de apresentar uma discussão relevante sobre inclusão no atual contexto social realizou-se a pesquisa bibliográfica, conforme define Gil (2001, p. 44) "a pesquisa bibliográfica é desenvolvida com base em material já elaborado, constituído principalmente de livros e artigos científicos". O material objeto de estudo dessa pesquisa foi o Estatuto da Pessoa com deficiência, selecionado o Capítulo IV, do direito à educação, art. 27, 28 e 30, considera-se que o Art. 29 foi vetado, sob - qual foi realizada uma abordagem 
qualitativa

Parafraseando com Ludke e André (2002, p. 11) "a pesquisa qualitativa tem o ambiente natural como sua fonte direta de dados e o pesquisador como seu principal instrumento." Segundo esses autores, a pesquisa qualitativa supõe o contato direto e prolongado do pesquisador com o ambiente e a situação que está sendo investigada.

\section{ANÁLISE DOS DADOS: DO DIREITO CONSTITUCIONAL À EDUCAÇÃO E A LEI № 13.146, DE 06 DE JULHO DE 2015}

\subsection{DO DIREITO À EDUCAÇÃO E A CARTA MAGNA}

O direito a Educação perpassa pela compreensão de que a todos é aplicado o princípio da igualdade, logo todos devem ser contemplados a ter a oportunidade de estudar, sendo competência comum da União, dos Estados, do Distrito Federal e dos Municípios, proporcionar os meios de acesso à educação, nos termos do Art. 23, inciso V, da Carta Constitucional do Brasil de 1988.

$\mathrm{Na}$ discussão da legalidade de igualdade, a Constituição Federal, no inciso I do art. 5으, aponta que:

\begin{abstract}
Todos são iguais perante a lei, sem distinção de qualquer natureza, garantindo-se aos brasileiros e aos estrangeiros residentes no País a inviolabilidade do direito à vida, à liberdade, à igualdade, à segurança e à propriedade. (BRASIL, 2008)
\end{abstract}

Partindo da compreensão de que todos têm direitos iguais, indiferente de qualquer natureza, seja social, cultural ou política, destaca-se o direito a vida, à liberdade, à igualdade, à segurança e à propriedade. Nessa discussão, tem-se 0 direito à igualdade que voltado para o contexto educacional compreende-se que todos têm o direito à Educação, como um direito social, previsto no Art. 6ำ da Constituição Federal.

A Educação desenvolvida no ambiente escolar se configura como um espaço democrático de discussão desenvolvida em um meio comum à aprendizagem de todos que a compõe. Destaca-se que será nesse lugar de convivência e relações que os profissionais da Educação formam cidadãos no que se referem seus valores e construções intrínsecas que auxiliarão na formação do autoconceito de cada um.

O ambiente escolar também é compreendido como formador de opiniões, devendo assim ser um lugar afável, sem distinção e nem preterimentos. Um lugar de convivência social que deve ser estendido a todos em igualdade de direitos.

Ao compreender a Educação como direito de todos e dever do Estado e da família (Art. 205, caput, da CF) inclui as pessoas com deficiências a partir de um sistema educacional inclusivo e que atenda de forma diferenciada a todos, com igualdade de condições para o acesso e permanência (206, I, CF), e, "atendimento educacional especializado" (Art. 208, inciso III, CF). Tais ações devem conduzir para o desenvolvimento social, cultural e cognitivo da pessoal.

Sendo assim, abre-se a discussão sobre o direito a Educação com recorte no Estatuto da Pessoa com Deficiência aprovado no final do ano de 2015, que entrou em vigor em 2016.

\subsection{DO DIREITO À EDUCAÇÃO E O ESTATUTO DA PESSOA COM DEFICIÊNCIA}

A Lei n 13.146/2015 dedica os artigos de 27 a 30, do Capítulo IV, do Título II, do Livro I, para tratar do Direito à Educação da pessoa com deficiência, de forma a assegurar um "sistema educacional inclusivo em todos os níveis e aprendizado ao longo de toda a vida".

O Art. 27 compreende que este direito à educação deve respeitar as características, interesses e necessidades de aprendizagem da pessoa com deficiência, de forma a alcançar o máximo desenvolvimento possível de seus talentos e habilidades físicas, sensoriais, intelectuais e sociais.

Para tanto, "é dever do Estado, da família, da comunidade escolar e da sociedade assegurar educação de qualidade à pessoa com deficiência, colocando-a a salvo de toda forma de violência, negligência e discriminação", conforme expresso no parágrafo único, do referido artigo 27.

A Lei evidencia que a inclusão deve acontecer tanto no Ensino Básico como no 
Superior, por meio de serviços e de recursos de acessibilidade que conduzam para construção um diálogo crítico, visando o envolvimento e a participação social dos sujeitos sociais historicamente marginalizados e incumbe ao poder público, conforme expresso no Art. 28, o dever de assegurar, criar, desenvolver, implementar, incentivar, acompanhar, avaliar e aprimorar o sistema educacional inclusivo em todos os níveis e modalidades.

Assim, destaca-se a importância e influência dos grupos sociais que remetem a fatos e conhecimentos que são fundamentais para o entendimento da sociedade. Dentre esse entendimento, há a necessidade de considerar os grupos minoritários, com suas particularidades, fatos, formações e conceitos constituídos através da diversidade cultural, histórica e filosófica de uma população.

Assim, apresenta ações que deverão ser desenvolvidas para atender a este sistema educacional inclusivo, que conduzem a um projeto pedagógico que institucionalize o atendimento educacional especializado, assim como os demais serviços.

Nesse atendimento educacional especializado tem-se a oferta de educação bilíngue, em Libras como primeira língua e na modalidade escrita da língua portuguesa como segunda língua, em escolas e classes bilíngues e em escolas inclusivas; a adoção de medidas que favoreçam o acesso, a permanência, a participação e a aprendizagem em instituições de ensino; as pesquisas voltadas para o desenvolvimento de novos métodos e técnicas pedagógicas, de materiais didáticos, de equipamentos e de recursos de tecnologia assistiva; a formação e disponibilização de professores para o atendimento educacional especializado, de tradutores e intérpretes de Libras, de guias intérpretes e de profissionais de apoio; a oferta de ensino de Libras, do Sistema Braille e de uso de recursos de tecnologia assistiva, entre outros atendimentos e serviços.

Quanto à adoção de medidas que favoreçam o acesso, a permanência, a participação e a aprendizagem em instituições de ensino, o Art. 30 expressa que nos processos seletivos para ingresso e permanência nos cursos oferecidos pelas instituições de ensino superior e de educação profissional e tecnológica, tanto públicas como privadas, devem procurar adotar medidas de atendimento preferencial à pessoa com deficiência nas dependências das Instituições de Ensino Superior (IES) e nos serviços.

Dentre essas medidas destaca-se a disponibilização de formulário de inscrição de exames com campos específicos para que o candidato com deficiência informe os recursos de acessibilidade e de tecnologia assistiva necessários para sua participação.

Destaca-se também a disponibilização de provas em formatos acessíveis para atendimento às necessidades específicas do candidato com deficiência; a disponibilização de recursos de acessibilidade e de tecnologia assistiva adequados, previamente solicitados e escolhidos pelo candidato com deficiência; a dilação de tempo, conforme demanda apresentada pelo candidato com deficiência, tanto na realização de exame para seleção quanto nas atividades acadêmicas, mediante prévia solicitação e comprovação da necessidade; adoção de critérios de avaliação das provas escritas, discursivas ou de redação que considerem a singularidade linguística da pessoa com deficiência, no domínio da modalidade escrita da língua portuguesa; e, tradução completa do edital e de suas retificações em Libras.

\subsection{A APLICABILIDADE DA LEI № $13.146 / 2015$}

A Lei $\mathrm{n}$ - $13.146 / 2015$ preconiza que a educação constitui direito da pessoa com deficiência, assegurados sistema educacional inclusivo em todos os níveis. O processo seletivo é a porta de entrada do aluno nas Instituições de Ensino Superior.

Com a Lei têm-se as ações a serem executadas para atender a todos, oportunizando o direito a concorrer à vaga no ensino institucionalizado de forma igualitária, cabendo a cada instituição adotar normativas que consolidem as ações determinadas no Art. 30 da referida lei. Estas normativas estão sendo, gradativamente, adotadas pelas Instituições de Ensino de Ensino Superior.

A instituição, ao recepcionar um discente com deficiência e mediante a Lei $\mathrm{n}$ 은 13.146/2015, tem como missão construir ações que atendam a referida lei, partindo do princípio que uma das maiores preocupações corresponde à aplicação 
eficaz do princípio da igualdade, para se contemplar a todos em igual oportunidade.

Nesse aspecto, para Fávero (2007) se faz pertinente admitir tratamentos diferenciados apenas como exceção, desde que eles tenham um fundamento razoável para sua adoção. Dentre esses tratamentos a Lei no 13.146/2015, no seu Art. 30, determina que nos processos seletivos para ingresso e permanência nos cursos oferecidos pelas instituições de ensino superior e de educação profissional e tecnológica, públicas e privadas, devem ser adotadas várias medidas diferenciadas.

Assim, no que se refere à entrada de alunos em Instituições pública de ensino tem-se a obrigatoriedade tanto na adaptação do Processo Seletivo Discente como ações que favoreçam a permanência dos discentes com deficiência nos ambientes escolares de todos os níveis de ensino.

Vale ressaltar que a Educação é um bem público e que a escola é um espaço público. Compreende-se que há um caráter público da Educação e isso deve ser levado em conta quando se fala do papel que as Instituições de Ensino têm socialmente, das características que apresenta mediante a sociedade que está inserida. A função de socialização do conhecimento e no acesso a determinadas informações do processo educativo institucionalizado.

Nota-se que o Art. 30, acima citado, atende ao direito à igualdade mediante a eliminação das desigualdades, o que impõe que se estabeleçam diferenciações específicas como única forma de dar efetividade ao preceito isonômico consagrado na Constituição (DIAS, 1998). Tal situação é atendida no momento que se prevê o atendimento preferencial a pessoa com deficiência; campo específico no formulário de inscrição para o candidato informar os recursos necessários a sua participação; maior tempo de prova; critérios de avaliação diferenciado, se for o caso; e, por fim a tradução dos Editais na Língua de Sinais.

Após a entrada do aluno na Instituição, ações deverão ser desenvolvidas para atender a pessoa com deficiência, dentro deste sistema educacional inclusivo, conforme preconiza o Art. 28 da Lei $n^{\circ}$ 13.146/2015.

A instituição deve estar preparada física e pedagogicamente para este desafio de inclusão. Para tanto, não basta à melhoria da estrutura física da instituição garantindo a acessibilidade.

Quanto à acessibilidade para pessoas com deficiência ou mobilidade reduzida, deve-se observar não só as condições de acessibilidade arquitetônica, que se refere à eliminação das barreiras físicas e garantia de transporte coletivo, como a acessibilidade atitudinal (programas com foco na diversidade), comunicacional (língua de sinais, linguagem corporal, linguagem gestual, virtual, etc., comunicação escrita, incluindo textos em braile, textos com letras ampliadas e outras tecnologias assistidas para comunicar), instrumental (que permiti a acessibilidade em relação a instrumentos como lápis, teclado de computador e materiais pedagógicos, entre outros) e programática (advindas de políticas públicas).

Há, ainda, a acessibilidade pedagógica, a qual se refere à ausência de barreiras nas metodologias e técnicas de estudo. Está relacionada diretamente à concepção subjacente à atuação docente: a forma como os professores concebem conhecimento, aprendizagem, avaliação e inclusão educacional, tudo irá determinar, ou não, a remoção das barreiras pedagógicas.

É preciso ter um bom projeto pedagógico, com currículos flexíveis e adaptados; atividades e materiais diversificados; preparação para a formação e exercício da docência; novas estratégias para o ensino e avaliação; ampliação do atendimento especializado; entre outras ações que promovam a permanência, a aprendizagem e o desenvolvimento integral do discente.

A estrutura curricular deve contemplar os aspectos de atualização, flexibilidade, formas de realização de interdisciplinaridade, acessibilidade pedagógica e atitudinal, compatibilidade da carga horária total, articulação da teoria com a prática e, nos casos de cursos a distância, mecanismos de familiarização com esta modalidade.

As tecnologias de informação e comunicação (TICs) no processo de ensino- aprendizagem devem permitir o desenvolvimento do projeto pedagógico do curso e garantir a acessibilidade, o desenvolvimento de habilidades com as TICs, com objetivo de permitir aos alunos a aproximação com os recursos tecnológicos a favor da melhoria da qualidade de educação. 
As TICs são recursos didáticos constituídos por diferentes mídias e tecnologias, tais como: ambientes virtuais e suas ferramentas, redes sociais e suas ferramentas, fóruns eletrônicos, blogs, chats, tecnologias de telefonia, teleconferências, videoconferências, TV convencional, TV digital e interativa, rádio, programas específicos de computadores (softwares), objetos de aprendizagem, conteúdos disponibilizados em suportes tradicionais (livros) ou em suportes eletrônicos (CD, DVD, Memória Flash, etc.), entre outros.

Destaca-se que para cada tipo de deficiência, necessidade ou transtorno há diferentes tipos de uso das tecnologias que podem favorecer um atendimento educacional especializado garantindo assim o aprendizado de todos. Para as pessoas com deficiência visual, por exemplo, dentre as tecnologias assistivas, há sintetizadores de voz que permite ler e escreve utilizando computadores e softwares (Dosvox, Jaws, Virtual Vision, entre outros). Os programas Mecdaisy alteram qualquer formato de texto, em texto digital falado, sendo disponibilizado gratuitamente no site do MEC.

O apoio ao discente é essencial para garantir seu acesso e permanência nas instituições de ensino, as quais devem desenvolver programas, projetos, ações, atividades de apoio social e/ou econômico, extraclasse e psicopedagógico, de acessibilidade, de atividades de nivelamento, extracurriculares e de participação em centros estudantis ou acadêmicos e em intercâmbios, que visem oferecer aos alunos maiores condições de aproveitamento de estudo, nivelamento, redução da evasão e melhoria da taxa de conclusão.

Assim, a inclusão social precisa ser assumida por todos, levando as pessoas a repensar suas concepções, a quebrar os paradigmas, para impulsionar novas possibilidades de acesso, participação e permanência das pessoas com deficiência em todos os níveis, etapas e modalidades de educação.

Portanto, a inclusão de pessoas com deficiência não se faz apenas por Leis, Decretos, Resoluções, mas com mudanças de atitudes, com novas propostas pedagógicas que assegurem recursos, apoios e serviços educacionais especializados, organizados para apoiar, complementar, suplementar e/ou substituir serviços educacionais existentes, com novas propostas de formação de professores e conscientização da sociedade, para que todos possam ser acolhidos pelas instituições de ensino, combatendo a exclusão e reafirmando o compromisso com uma política de inclusão.

\section{CONSIDERAÇÕES FINAIS}

Toda construção social tem aspectos socioculturais que influenciam na compreensão da organização social, precisase compreender como individuo social como esse elemento implica em reconhecer a importância epistemológica dos aspectos subjetivos do ser humano, tais como: sentimentos, simbolismos, crenças, representações e outras situações que fazem parte da sociedade.

Ao longo dos anos, a sociedade ou grupos sociais vêm se organizando para construir e efetivar os espaços inclusivos, formulando novas legislações e construindo caminhos para efetivar seus direitos como forma de enfrentamento à desigualdade das minorias. Vale ressaltar que a partir da compreensão de novas legislações no final do ano de 2016 foi publicada a Lei no 13.409 , de 28 de dezembro de 2016, que altera a Lei no 12.711, de 29 de agosto de 2012, para dispor sobre a reserva de vagas para pessoas com deficiência nos cursos técnico de nível médio e superior das instituições federais de ensino.

Assim, no ordenamento jurídico as pessoas com deficiência foram as primeiras minorias a serem tutelados por normas protetivas, as quais espraiam por diversas legislações, inclusive educacionais, culminando com a promulgação da Lei no 13.146/15.

Entretanto, a educação inclusiva é um desafio que tem que ser vencido dia a dia, a partir do compromisso de todos (Estado, comunidade, família, gestores, docentes e discentes) e de ações que permitam o acesso e a permanência de todos aos diferentes níveis de ensino.

A discussão sobre inclusão social tem modificado o processo educacional das instituições, possibilitando, não só a inserção de novas políticas de educação, como também a ascensão do profissional no mercado. Há um desafio na atividade do 
docente que é tomar consciência de como estão implicados no seu profissionalismo a conservação e a mudança do conhecimento, valores e paradigmas sociais. Compreender o processo sócio histórico conduzirá a defesa e consolidação da educação inclusiva.

Há cursos de graduação, especialização e extensão que aprofundam à discussão acerca de questões relativas ao processo de inclusão educacional e social da pessoa com deficiência considerando que a questão central para viabilizar um modelo de escola e sociedade inclusiva reside na formação de profissionais, que precisam ser efetivamente capacitados a transformar sua prática profissional.

Os projetos pedagógicos estão modificando pouco a pouco para que se institucionalize o atendimento educacional especializado, assim como os demais serviços e adaptações razoáveis, para atender às características dos estudantes com deficiência e garantir o seu pleno acesso ao currículo em condições de igualdade, promovendo a conquista e o exercício de sua autonomia.

Contudo, há carência de mais pesquisas voltadas para o desenvolvimento de novos métodos e técnicas pedagógicas, de

\section{REFERÊNCIAS}

[1] Berge, Peter. L. E Luckmann, Thomas. A Construção Social da Realidade. Tradução de Floriano de Souza Fernandes. 21르 Edição. Petrópolis: Vozes, 2002.

[2] Brasil. Ministério da Educação. Diretrizes Nacionais para Educação Especial na Educação Básica. Secretaria de Educação Especial: MEC; SEESP, 2001.

[3] Brasil. Ministério de Educação e Cultura. LDB - Lei no 9394/96, de 20 de dezembro de 1996. Estabelece as diretrizes e bases da Educação Nacional. Brasília: MEC, 1996. BRASIL. Presidência da República. Lei no 13.146, de 06 de julho de 2015. Institui a Lei Brasileira de Inclusão da Pessoa com Deficiência (Estatuto da Pessoa com Deficiência). Brasília: 2015.

[4] Brasil. Presidência da República. 13.409, de 28 de dezembro de 2016. altera a Lei no 12.711, de 29 de agosto de 2012, para dispor sobre a reserva de vagas para pessoas com deficiência nos cursos técnico de nível médio e superior das instituições federais de ensino. Brasília: 2016

[5] Bonetti. Nilva. Leis de diretrizes e bases e suas implicações na formação de professores de educação infantil. In: Alitino Filho, José Martins. (org.). Criança pede respeito: temas em materiais didáticos, de equipamentos e de recursos de tecnologia assistiva para capacitar os professores e facilitar o ensino às pessoas com deficiências.

A razão dessa carência de pesquisas pode ser entendida pela legitimação naturalizada dos discursos homogênicos de uma sociedade, que exclui essas existências e também impede o questionamento da diversidade de saberes que a compõem e suas mais variadas diversidades humana.

Pensar a educação inclusiva não tem sido algo muito difícil, mas é preciso que as ações efetivem a inclusão de pessoas com deficiência em todos os níveis e modalidades de ensino, para que haja a aplicabilidade da lei em assegurar um sistema educacional inclusivo para todas as instituições de ensino selecionam determinados elementos/conteúdos a serem trabalhado com os alunos, cidadãos do mundo.

Afinal, o convívio escolar apresenta-se como um fator importante para a aprendizagem de valores e atitudes, quando considera-se o ambiente escolar, seja no ensino básico ou superior como um dos ambientes mais imediatos do aluno, relação a elas se darão a partir do próprio cotidiano da vida escolar dos alunos. (PCN's, 2001).

educação infantil. Porto Alegre: Mediação, 2005.

[6] Dias, Maria Berenice. Ações afirmativas: uma solução para a desigualdade. Revista Del Rey, no 04, dez/1998.

[7] Fávero, Eugênia Augusta Gonzaga. O direito a uma educação inclusiva. In: Gugel, Maria Aparecida Gugel; Costa Filho, Waldir Macieira da; RIBEIRO, Lauro Luiz Gomes (orgs.). Deficiência no Brasil: uma abordagem integral dos direitos das pessoas com deficiência. Florianópolis: Obra Jurídica, 2007.p. 89-109.

[8] Ferreira, Windyz B. Inclusão $x$ exclusão no Brasil: reflexões sobre a formação docente dez anos após Salamanca. Rodrigues, David (org.). Inclusão e educação: doze olhares sobre a educação inclusiva. São Paulo: Summus, 2006.

[9] Gil, Antônio Carlos. Como elaborar projeto de pesquisa. 4a Edição: São Paulo, Atlas, 2002.

[10] Klein, Rejane Ramos. A escola inclusiva e alguns desdobramentos curriculares. In: Klein, Rejane Ramos (org). Inclusão Escolar: implicações para o currículo. Coleção docentes em formação. São Paulo: Paulinas, 2010. p. 11-28.

[11] Lüdke, Menga; André, Marli Eliza Dalmazo Afonso de. Pesquisa em Educação: abordagem qualitativa. São Paulo, SP: EPU, 2001. [12] Mittler, Peter. Educação Inclusiva. Contextos Sociais. São Paulo: Artemed, 2003. 
Santos, Iolanda Universina Montano dos. O "direito de ser diferente" um debate para (re) pensar a inclusão escolar. In: Klein, Rejane Ramos (org). Inclusão Escolar: implicações para o currículo. Coleção docentes em formação. São Paulo: Paulinas, 2010. p. 29-50.

[13] Schmitz, Egidio Francisco.

Fundamentos da Didática. 7. ed São

Leopoldo: UNISINOS,

[14] 1993.

[15] Stainback, Susan; Stainback, Willian. Inclusão: um guia para educadores. Trad. Magda França Lopes, Porto Alegre: Artmed, Rio Grande do Sul, 1999. 


\section{Gapítulo 12}

\section{MOTIVACẼO DOS ALUNOS EM SALA DE AULA: COMPARACẼ̃O ENTRE UMA AULA ATIVA DE UM CURSO SEMIPRESENCIAL E UMA AULA EXPOSITIVA DE UM CURSO PRESENCIAL DA ÁREA DE SAÚDE.}

\section{Paula Moiana da Costa}

Fernando Hitomi Matsubara

Samia Moreira Akel

Resumo: Diante de diversos meios de obtenção de informações, o educador não é mais a única fonte, porém é essencial para a construção do saber, uma vez que deve preparar os alunos para sistematização e formalização deste conhecimento. Entretanto, ao aplicar uma nova metodologia na educação, no entanto, existe uma dificuldade implícita no que diz respeito à mensuração de sua validade e resultados no processo de ensino-aprendizagem, uma vez que são critérios subjetivos a serem trabalhados. Para tal, o presente trabalho realizou a comparação da motivação de alunos em uma turma de um curso presencial com aulas expositivas e uma turma de um curso semipresencial com aulas ativas, utilizando o instrumento EMSI. Uma vez que a motivação é considerada como fundamental para o processo de ensinoaprendizagem, podemos sugerir a partir dos dados coletados que ambas as técnicas atingem seus objetivos no que se refere ao engajamento do estudante.

Palavras- Chave: Motivação, curso presencial, híbrido. 


\section{INTRODUÇÃO}

O ensino superior manteve sua formatação expositiva e tradicional por centenas de anos. Porém, com a evolução tecnológica, novas demandas foram impostas e alterações não apenas na comunicação foram percebidas (Sousa et al, 2011). O impacto das novas tecnologias alterou significativamente 0 comportamento da população de forma geral. A evolução da tecnologia somada as alterações sociais tornou os jovens cada vez mais imediatistas, que formulam questões cujas respostas tem o tom de ansiedade e urgência. Docentes referem que seus alunos demonstram cada vez menos interesse por longas aulas expositivas (Santos \& Soares, 2011). Consulta às referências online permitem sanar dúvidas de maneira rápida e eficiente, quando as ferramentas são utilizadas corretamente.

Essa alteração comportamental acabou gerando novos produtos, na tentativa de satisfazer a demanda de uma nova geração. O ensino a distância (EaD) encontrou espaço no mercado com uma proposta inovadora, permitindo flexibilidade nos horários de estudo, bem como economia no deslocamento para os campi universitários (Almeida Júnior, 2013). Entretanto, a nova configuração também deixou lacunas em alguns casos, ex. ausência de aulas práticas, tutoria online como única forma de tirar dúvidas, ausência de contato com demais alunos, convívio universitário. Ressalta-se a presença do professor como um facilitador no processo de aprendizagem - ao longo de leituras de livros e demais materiais, o professor ainda se faz uma figura que auxilia na compreensão de conhecimentos teóricos e práticos, tanto na forma de tutoria como presencial, em cursos híbridos. Nesse espaço, percebeu-se então a necessidade de uma nova modalidade, que atenda tanto a demanda de tempo e conveniência como também a necessidade de um espaço para práticas. O ensino híbrido ganha força no cenário brasileiro, juntando tecnologia com atividades presenciais, e a área da saúde começa a perceber essa necessidade. Estudos comparativos entre as diversas modalidades são indispensáveis para que se avalie tanto a forma de implementação quanto aprimoramento dos currículos propostos até o momento.

\section{METODOLOGIA}

Participaram desse estudo alunos matriculados nos cursos de Biomedicina e Nutrição da Universidade Positivo (Brasil), na disciplina de Anatomofisiologia. Os alunos do curso de Nutrição aprendem o conteúdo por meio de aulas expositivas e práticas no modelo de treinamento tradicional, sendo 1 hora de aula expositiva e 1 hora de prática na frequência de uma vez por semana.

A turma de Biomedicina cursa a disciplina na modalidade híbrida, onde durante duas semanas realizam a leitura do e-book disponibilizado (em torno de 20 paginas por capítulo), assistem uma vídeo aula com exemplos práticos (com duração aproximada de 7 minutos), respondem questões online (5 questões) e tem possibilidade de acessar um fórum de dúvidas com uma tutora online. Ao final deste período, participam de atividades presenciais realizadas por meio de metodologias ativas (dentre as mais utilizadas, Team Based Learning e Class Rotation), num período de 8 horas de aulas sequenciais.

Ao final das atividades, os alunos foram submetidos á aplicação do instrumento da Escala de Motivação Situacional (EMSI), proposto por Guay et al (2000) e validado para a língua portuguesa para o contexto acadêmico por Gamboa et al (2013). A resposta ao instrumento foi anônima e voluntária por parte dos alunos, sendo respeitadas as recusas ao preenchimento sem qualquer tipo de constrangimento.

Trinta e um (31) alunos do curso de Nutrição responderam o formulário a partir de suas experiências na disciplina após um mês de aulas, e trinta e oito (38) alunos do curso de Biomedicina o fizeram após período similar.

As respostas a auto-descrição da correspondência ás circunstâncias motivacionais descritas no instrumento corresponderam a escala de 1 a 7 , sendo 1 considerada como "não corresponde de nenhum modo" e 7 como "corresponde exatamente", conforme previsto no próprio instrumento da EMSI. As análises foram realizadas apela somatória das respostas que remetem a Motivação Intrínseca (MI), Regulação Identificada (RI), Regulação Externa (RE) e Desmotivação (D), comparadas entre as turmas.

A análise dos resultados foi realizada com o auxílio do software de livre distribuição 
BioEstat 5.3, através dos testes estatísticos não paramétricos Kruskall-Wallis e Mann Whitney.

\section{RESULTADOS E DISCUSSÃO}

O impacto das atuais transformações econômicas, políticas, sociais e culturais na educação, na escola e, em especial, no processo de ensino-aprendizagem no contexto da sala de aula é facilmente reconhecível. Os vínculos entre as práticas educativas e as transformações do mundo contemporâneo estreitaram-se consideravelmente, em função dos avanços tecnológicos e dos meios de comunicação, que envolvem novas exigências educacionais (Silva \& Correa, 2014). Isso porque, diante de diversos meios de obtenção de informações, o educador não é mais a única fonte, porém é essencial para a construção do saber, uma vez que deve preparar os alunos para sistematização e formalização deste conhecimento.

Ao aplicar uma nova metodologia na educação, no entanto, existe uma dificuldade implícita no que diz respeito à mensuração de sua validade e resultados no processo de ensino-aprendizagem, uma vez que são critérios subjetivos a serem trabalhados (Fairchild et al, 2006). Uma vez que o que o sucesso do processo de aprendizagem baseado em modelos hibridos de ensino, com a inserção de salas de aula invertidas, relaciona-se em grande parte ao próprio desejo do aluno de se engajar nas atividades propostas., uma das necessidades de pesquisa relacionadas ao uso de EAD e ensino híbrido é a medida da percepção e motivação do aluno para realizar as atividades propostas nesta metodologia de ensino (Abbad et al, 2010). Portanto, neste estudo, escolhemos o uso da Escala de Motivação Situacional (EMSI), a medida da motivação intrínseca e extrínseca situacional já adaptada e validada ao português (Gamboa et al, 2013).

Os resultados obtidos pela somatória das respostas que remetem a Motivação Intrínseca (MI), Regulação Identificada (RI), Regulação Externa (RE) e Desmotivação (D), como auto-descrição da correspondência ás circunstâncias motivacionais descritas no instrumento EMSI para as turmas de Nutrição (Curso presencial, com aula expositiva) e Biomedicina (Curso semipresencial com aula por metodologias ativas) podem ser observados na Tabela 1.

Tabela 1: Descrição estatística das somatórias das respostas que remetem a Motivação Intrínseca (MI), Regulação Identificada (RI), Regulação Externa (RE) e Desmotivação (D), como auto-descrição da correspondência ás circunstâncias motivacionais descritas no instrumento corresponderam a escala de 1 a 7 , sendo 1 considerada como "não corresponde de nenhum modo" e 7 como "corresponde exatamente", conforme previsto no instrumento da EMSI nas turmas de Nutrição e Biomedicina

\begin{tabular}{|c|c|c|c|c|c|}
\hline & & MI & RI & RE & \\
\hline Turma & Média & 22.52 & 23.05 & 14.62 & 5.14 \\
\hline Presencial e & $\begin{array}{l}\text { Desvio } \\
\text { Padrão }\end{array}$ & 4.54 & 3.71 & 5.57 & 1.74 \\
\hline & Mediana & 23 & 24 & 15 & 4 \\
\hline Turma & Média & 21.39 & 24.89 & 15.25 & 8.80 \\
\hline Semipresencial & $\begin{array}{l}\text { Desvio } \\
\text { Padrão }\end{array}$ & 4.11 & 3.52 & 6.11 & 5.50 \\
\hline & Mediana & 21.5 & 26 & 14.5 & 7 \\
\hline
\end{tabular}

A análise dos dados indica que a Motivação intrínseca (MI), como a Regulação Identificada (RI), a Regulação Externa (RE) e a Desmotivação (D) apresentaram-se estatisticamente similares entre os dois grupos, considerando $p<0,05$ significativo.

Estes resultados foram semelhantes aos encontrados por Akel et al(2016), num estudo 
comparativo da motivação dos alunos numa aula expositiva e em aula através de metodologias ativas, dentro de um modelo de ensino Blended num curso de graduação presencial. Neste trabalho, entretanto, observou-se que os alunos provenientes da disciplina no modelo Blended apresentaram uma Regulação Externa maior do que a observada na aula expositiva tradicional, fato este associado ao estabelecimento recente do formato ativo no curso, gerando dependência por parte dos alunos da orientação do professor para a compreensão e subsequente realização das atividades propostas. No presente estudo não foram observadas estas diferenças relacionadas a Regulação Externa.

É necessário pontuar que o instrumento EMSI foi aplicado para a turma que recebeu a aula expositiva tradicional durante 50 minutos, enquanto a turma do ensino híbrido o respondeu após 8 horas-aula de atividades. Ainda que a motivação possa ser mantida por neste período, a comparação das turmas após o mesmo tempo de inserção nos diferentes contextos de aprendizagem poderiam explicitar maiores diferenças.

Além disso, outros aspectos devem ser considerados. A expectativa de um estudante em relação a sua vivência em sala está relacionada ao método escolhido por ele mesmo para seu processo de aprendizagem. Pode-se considerar que alunos que optam

\section{REFERÊNCIAS}

[1] Abbad, G. S., Zerbini, T., de Souza, D. B. L. (2010). Panorama das pesquisas em educac,ão a distância no Brasil (Overview of research in distance education in Brazil. Psychology studies). Estudos de Psicologia, 15(3).

[2] Almeida Junior, R. M. (2013). O ensino a distância e as novas tecnologias. Revista Primus Vitam, (1) 5,

[3] Akel, S. M ; Costa, P. M . (2016) Comparing Blended learning and traditional training in anatomy teaching . International Conference on Education and New Learning Technologies. Barcelona, Spain.

[4] Fairchild, S. R., Pillai, V. K., Noble, C. (2006). The impact of a social work study abroad program in Australia on multicultural learning. International Social Work. 49: pp. 390-401. por cursos presenciais esperam que as aulas sejam expositivas, ao passo que os que preferem modelos híbridos consideram atividades ativas como parte integrante do método de ensino. Uma vez que a opção por um ou outro modelo de curso é individual e voluntária, plenamente auto-regida, a semelhança dos resultados obtidos entre contextos tão discrepantes podem dar indícios de possíveis diferenças no perfil dos alunos, intrinsecamente associadas ao sentirse confortável com uma ou outra técnica de ensino.

\section{CONSIDERAÇÕES FINAIS}

Ainda que as diferenças entre as técnicas e saberes utilizados pelos docentes em aulas expositivas de cursos presenciais e aqueles aplicados em cursos híbridos com sala de aula invertida sejam bastante visíveis, no presente trabalho não foi possível verificar diferenças na motivação dos alunos de um ou outro método. Atribui-se a isso o perfil do aluno, a partir de sua expectativa em relação ao método no qual se baseia sua escolha. Uma vez que a motivação é considerada como fundamental para o processo de ensino-aprendizagem, podemos sugerir a partir dos dados coletados que ambas as técnicas atingem seus objetivos no que se refere ao engajamento do estudante.

[5] Gamboa, C. et al (2013) Validação da versão portuguesa da Situacional Motivation Scale (SIMS) em contextos acadêmicos. Anais do XII Congresso Internacional Galego - Português de Psicopedagogia. Braga: Universidade do Minho.

[6] Guay, F. et al (2000). On the assessment of situacional intrinsic and extrinsic motivation: the situacional motivation scale (SIMS). Motivation and Emotion. (24).

[7] Santos, C. P. \& Soares, S. R. (2011). Aprendizagem e relação professor-aluno na universidade: duas faces da mesma moeda. Est. Aval. Educ, 22(49)

[8] Silva, R. F; Correa, E. S. (2014). Novas tecnologias e educação: a evolução do processo de ensino e aprendizagem na sociedade contemporânea. Educação \& Linguagem, (1) 1.

Sousa, R. P., Moita, F. M. C. \& Carvalho, A. B. G. (2011). Tecnologias Digitais na Educação. Universidade Estadual da Paraíba: EDUEPB. 


\section{Gapítulo 13}

\section{ILHA INTERDISCIPLINAR DE RACIONALIDADE: POTENCIAL DO COMPLEXO DO VER-O-PESO COMO CONTEXTO PARA APRENDIZAGEM DE CIENCIAS NATURAIS}

\section{Jorge Raimundo da Trindade Souza \\ José Alexandre da Silva Valente \\ Ana Cristina Pimentel Carneiro de Almeida \\ Licurgo Peixoto de Brito}

Resumo:Este trabalho tem o objetivo de verificar o potencial do complexo do Ver-oPeso (Belém-PA) como contexto para aprendizagem de Ciências Naturais. Nesta proposta o complexo torna-se tema para a construção de llhas Interdisciplinares de Racionalidade (IIR) na perspectiva Ciência, Tecnologia e Sociedade (CTS). Assim, desenvolvemos uma pesquisa com 30 alunos, concluintes do curso de Ciências Naturais, da Universidade Federal do Pará (UFPA). Como instrumento de coleta de dados, foram utilizadas as sínteses das IIR construídas pelos alunos, após uma visita ao complexo. Os resultados apontam que existe ampla variedade de conhecimentos no complexo do Ver-o-Peso que podem proporcionar o desenvolvimento de IIR, refletindo na construção de uma aprendizagem dinâmica e participativa com a atribuição de significados. Conclui-se que o Ver-o-Peso é um ambiente adequado para a construção de atividades experimentais utilizando a abordagem CTS, a partir de IIR, evidenciando a relação entre os conhecimentos científicos e o cotidiano.

Palavras chave: Ilhas Interdisciplinares de Racionalidade, Ensino de Ciências, Vero-Peso. 


\section{INTRODUÇÃO E FUNDAMENTAÇÃO} TEÓRICA

A capital do estado do Pará, Belém, completou 400 anos em 12 de janeiro de 2016. A cidade fundada por Francisco Caldeira Castelo Branco em 1616, com o objetivo de proteger a entrada da Amazônia de estrangeiros, se destaca na região norte do Brasil pela sua cultura, gastronomia e também pela sua economia. $O$ principal cartão postal de Belém, o mercado do Ver-oPeso (Figura 1), completou, em 2017, 390 anos de atividade. O nome do mercado deriva do local, às margens da baía do Guajará, ter sido um posto de fiscalização da coroa portuguesa, onde funcionava a Casa de Haver O Peso.

A maior feira ao ar livre da América Latina tem uma história peculiar. Nasceu como um entreposto fiscal no século XVII, em uma área que era formada pelo igarapé do Piri. Ali, com base no peso dos produtos, eram tributadas todas as mercadorias que chegavam à cidade, ficando conhecido como 'Casa de Haver o Peso' (BELÉM, 2016)

Figura 1 - Vista parcial do Complexo do Ver-o-Peso

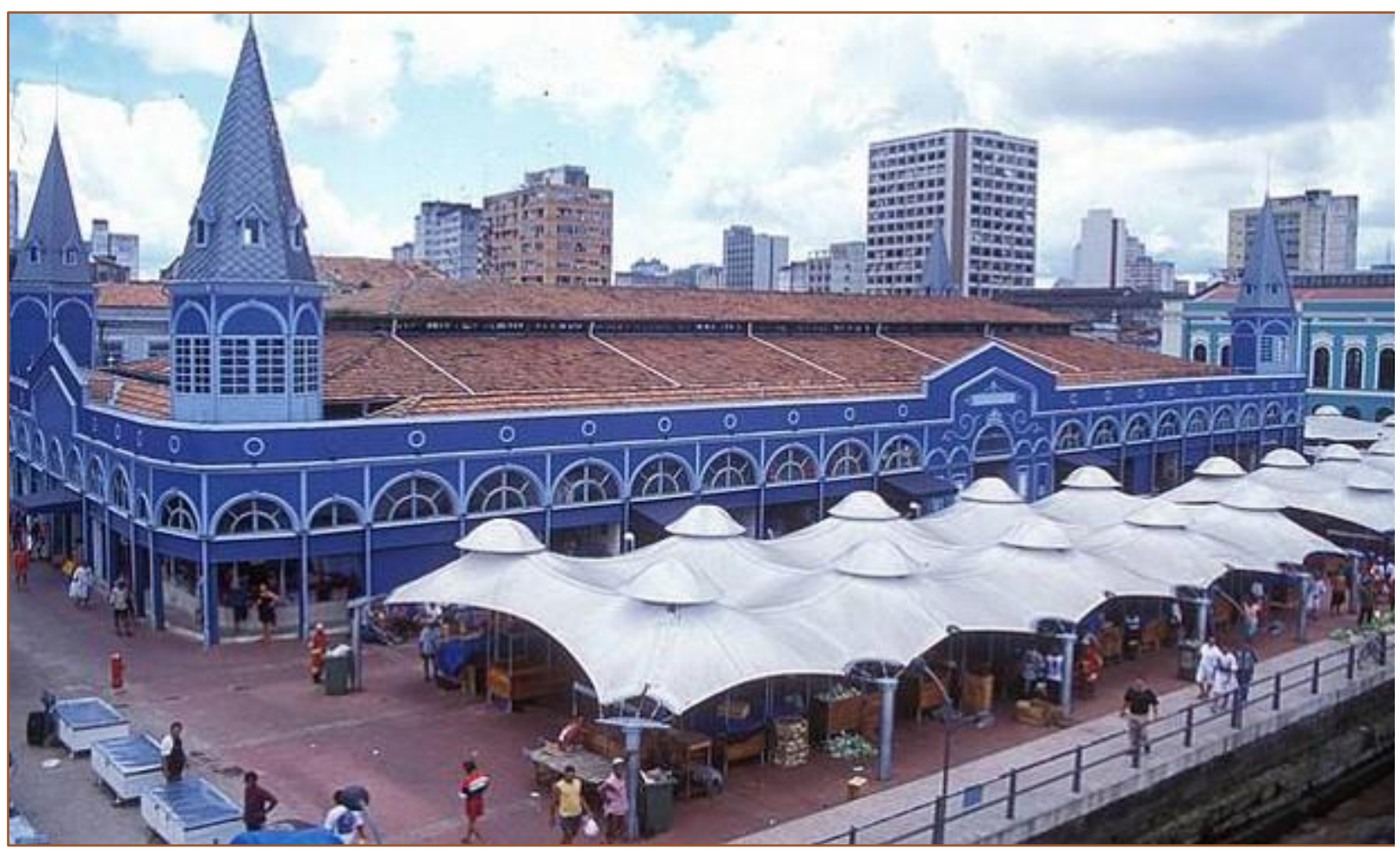

Fonte: Casarão de Memórias da Amazônia (Disponível em http://casaraodememorias. blogspot.com.br/2016/03/caso-ver-o-peso-iphan-abre-consulta.html).

O complexo do Ver-o-Peso, abrange o Mercado de Ferro, o Mercado Municipal e a feira-livre. As docas que emolduram o bairro da Cidade Velha, onde se localiza o complexo, testemunham a presença marcante da arquitetura de ferro, sobretudo inglesa, que nos dão ideia do apogeu econômico do ciclo do látex na Amazônia. ${ }^{2}$ Integram ainda o complexo a Praça do Relógio, a Feira do Açaí, a Ladeira do Castelo, o Solar da Beira e a Praça do Pescador.

Neste local, de grande simbolismo para os belenenses, rico intercâmbio cultural e uma

2

http://www.orm.com.br/tvliberal/revistas/verpara/edi cao2/index.htm 
complexa teia de relações sociais, a maioria dos produtos da floresta amazônica podem ser encontrados e comercializados para várias regiões do país e do mundo.

Diversos produtos são comercializados no complexo do Ver-o-Peso, que é uma representação cultural da cidade, do Pará e da floresta amazônica, com uma diversidade de aromas, pessoas, comidas, frutas, bebidas, artesanatos e culturas envolvidas com a venda de produtos tipicamente amazônicos e paraenses.

Entre os produtos vendidos neste mercado se destacam o açaí e outras frutas regionais, produtos hortifruti e o pescado. Segundo o Dieese, são vendidas no complexo cerca de 30 toneladas de açaí por ano, 30 toneladas de hortaliças por mês e até 15 toneladas de pescado por dia. $^{3}$

Segundo estimativas do Departamento Intersindical de Estatística e Estudos Socioeconômicos (Dieese), as atividades econômicas do Ver-o-Peso injetam na economia paraense, diariamente, cerca de $\mathrm{R} \$$ 1,3 milhões, com aproximadamente cinco mil pessoas trabalhando em 12 setores do gigantesco espaço de 30 mil metros quadrados, e uma circulação média de 50 mil pessoas por dia (BELÉM, 2016).

Em alusão a estas datas comemorativas pensamos no desenvolvimento de uma pesquisa que pudesse evidenciar o potencial do complexo do Ver-o-Peso, que tem reconhecida densidade histórica e comercial, como contexto para aprendizagem de Ciências Naturais, como tema da construção de uma ilha interdisciplinar de racionalidade. Nesse sentido, entendemos como Cachapuz (2012, p. 19) "tudo se torna mais fácil quando a aprendizagem das ciências não envolve senão uma descrição fenomenológica do mundo". Entendemos que o "mundo" peculiar evidenciado no Ver-o-Peso, condensa uma gama de fenômenos naturais, sociais, antropológicos e históricos que o tornam apto a estimular a curiosidade epistemológica da qual nos fala Paulo Freire.

A aprendizagem de Ciências Naturais a partir de contextos reais, concretos, em busca posterior de abstrações, tem sido explorada por diversas estratégias de ensino (e.g.

\footnotetext{
3 http://g1.globo.com/pa/para/noticia/2015/03/Vero-Peso-comemora-388-anos-com-fogos-eprestacao-de-servicos.html
}

BRITO; GOMES, 2007 e ANGOTTI, 2015) particularmente na perspectiva CTS. Apesar das IIR serem oriundas da concepção de $\mathrm{ACT}$, as convergências entre ACT e CTS, já anunciadas e discutidas por Sousa (2007), permitem encontrar elementos do ensino com enfoque CTS no desenvolvimento de uma IIR.

O enfoque de ensino CTS tem nascedouro no Movimento CTS que se refere a um movimento de atenção às relações entre Ciência, Tecnologia e Sociedade e sua continua interação. Esse movimento teve origem no momento em que se tornou claro o uso político da Ciência e da Tecnologia nas relações de poder tornando explicita a não neutralidade tanto da Ciência quanto da Tecnologia como, por exemplo, nas situações de guerra.

Nos dias de hoje, as reflexões acerca do Movimento CTS nos conduzem para a inclusão deste movimento na educação científica, introduzindo as relações entre Ciência, Tecnologia e Sociedade nos objetivos gerais da educação em ciências. Estabelecendo o que chamamos hoje de enfoque CTS ou abordagem CTS no ensino de ciências (AULER; BAZZO, 2001).

Cabe apontarmos para a necessidade de atentar para o papel da escola e do professor no caminho do enfoque CTS e os efeitos dessa abordagem em seus alunos, contrapondo a formação do professor que vem sendo estabelecida de forma predominantemente disciplinar, trazendo dificuldades de adaptação ao desafio do enfoque CTS e à sua perspectiva contextualizada e interdisciplinar, seja por falta de domínio dos conteúdos científicotecnológicos ou mesmo por falta de conhecimento sobre as propostas do enfoque CTS (AULER; BAZZO, 2001).

Professores e licenciandos da área científica precisam buscar assumir uma postura mais próxima da nova abordagem, em seus princípios e motivações, organizando situações pedagógicas que procurem abordar temáticas de caráter social em suas aulas.

Nessa busca, o emprego de temas sociais no ensino é referenciado por vários autores como a principal estratégia da abordagem CTS. Angotti e Auth (2001), Santos e Schnetzler (2010) e Santos (2007) atribuem à abordagem CTS um papel importante para a integração de temas sociais ao ensino que possibilitam o 
desenvolvimento de competências e habilidades essenciais à formação cidadã.

Um expediente para romper com o modelo tradicional da educação brasileira, refratário às transformações pretendidas para um ensino de Ciências que atenda às exigências reais da sociedade, é a implementação progressiva de práticas intermediárias, como a utilização de Microtemas, Ensino Através de Temas, Temas Geradores e as Ilhas Interdisciplinares de Racionalidade, que são características da perspectiva CTS. Embora as IIR sejam materialização da Alfabetização Científica e Técnica (ACT), conforme Fourez (1997), os vínculos com a abordagem CTS são inegáveis (RICARDO et al., 2004; SOUSA, 2007). É nessa perspectiva que associamos as IIR com a abordagem Ciência, Tecnologia e Sociedade.

\section{METODOLOGIA}

A pesquisa se classifica como aplicada, estudo de campo e de natureza qualitativa e quantitativa. A coleta de dados/informações foi efetuada em julho de 2015 com 14 alunos e julho de 2016 com 16 alunos, todos concluintes do curso de Ciências Naturais, da Universidade Federal do Pará (UFPA), do campus de Belém. A média de idade dos alunos era de 22 anos. Como instrumento de coleta de dados, foram utilizadas as sínteses das IIR construídas pelos alunos, após uma visita ao Ver-o-Peso. Para apoiar a análise dos resultados, foram destacados excertos das sínteses, utilizando-se a análise interpretativa (ESTEBAN, 2010) como ferramenta metodológica.

$\mathrm{Na}$ intenção de construir este artigo foram selecionados alunos, prováveis concluintes, de 2015 e 2016 de Licenciatura em Ciências Naturais pelo fato de, na disciplina Educação em Ciência e Tecnologia, ofertada no penúltimo semestre, já ter sido realizada a abordagem dos conhecimentos introdutórios sobre os estudos de CTS, inclusive sobre as IIR.

Inicialmente foi (re) apresentado para os alunos de Ciências Naturais o desenvolvimento de uma IIR, as vantagens da utilização desta estratégia e como esta IIR pode ser incorporada na sua práxis pedagógica futuramente, ou seja, o desenvolvimento deste estudo também teve caráter instrumental.
Embora o objetivo desta atividade fosse também o de instrumentalizar estes alunos sobre a IIR, os mesmos cumpriram as oito etapas propostas por Fourez (1997) na construção de uma IIR, sendo que algumas caixas-pretas, foram apontadas como potencial a ser explorado no ensino de Ciências Naturais no ensino fundamental, e não como dúvidas dos licenciados pesquisados.

Nos dois momentos da pesquisa (anos 2015 e 2016) os alunos se dividiram em equipes de 3 a 4 integrantes com o objetivo de, no próprio local, observar e registrar vários saberes científicos e saberes populares presentes no mercado do Ver-o-Peso associados ao ensino de Ciências Naturais, para posteriormente relatar e socializar em sala de aula com os demais membros da pesquisa as informações coletadas no mercado. Correspondendo ao que Fourez considera como o "descer ao terreno" ou "indo a prática" como veremos a seguir nas etapas da construção de IIR.

Ao final, cada equipe construiu a sua própria síntese e apresentou para os demais alunos das outras equipes, ocorrendo neste momento uma nova discussão e reflexão, que resultou em correções no sentido de responder adequadamente a pergunta que foi levantada na primeira etapa da ilha: Que conteúdos científicos associados ao ensino de Ciências Naturais podem ser observados e contextualizados pelos professores desta disciplina escolar, como conhecimentos científicos e saberes populares que emergem do complexo do Ver-o-Peso nos 400 anos de Belém (PA).

A seguir, apresentamos as etapas sugeridas por Fourez para a contrução de uma IIR e que foram realizadas nesta pesquisa:

\section{ETAPAS PARA A CONSTRUÇÃO DE ILHAS INTERDISCIPLINARES DE RACIONALIDADE (IIR), NA PERSPECTIVA DE UMA ALFABETIZAÇÃO CIENTÍFICA E TÉCNICA}

Fourez (1997) propõe oito etapas sequenciais a fim de viabilizar a construção de uma IIR, no sentido de promover a Alfabetização Científica e Técnica. Essas etapas também estão descritas em Nehring et al. (2002) e são apresentadas sinteticamente a seguir. Vale ressaltar que não se faz necessário o cumprimento dessas etapas de forma linear, pois "elas são flexíveis e abertas, em alguns casos podendo ser suprimidas e/ou 
revisitadas, quantas vezes a equipe julgar necessário" (NEHRING et al., 2002, p. 9).

1) Realizar um clichê da situação: Corresponde à etapa inicial caracterizando-se como uma problematização ou questionamentos iniciais do grupo quase sempre partindo das experiências cotidianas deles. Esses questionamentos poderão refletir suas ideias intuitivas exprimindo suas concepções e dúvidas acerca de um contexto. Convém ressaltar que, nessa etapa, poderão ocorrer pensamentos corretos ou incorretos sobre o contexto estudado muito próprio do início de um estudo. O produto dessa primeira etapa poderá ser a esquematização desses pensamentos iniciais ou a listagem dos questionamentos sobre o contexto a ser estudado.

2) Elaborar o panorama espontâneo: A intenção aqui é a ampliação do clichê, ainda em processo espontâneo, sem ajuda de especialistas sobre a temática, no qual professores e estudantes levantam outras questões ou revitalizam questões abandonadas no clichê. Nesta etapa, como enfatizam Pinheiro e Pinho-Alves (2005), ocorre: (a) refinamento e/ou melhor delineamento das questões, (b) definição dos participantes, (c) levantamento de normas e restrições de interesses e tensões, (d) listagem dos diversos aspectos da situação que serão abordados no projeto, (e) escolha dos caminhos a seguir, (f) lista dos especialistas e/ou especialidades relacionados com a temática.

3) Consultar os especialistas e as especialidades: Essa etapa ocorre no momento em que determinado assunto envolvido com o projeto não puder ser esclarecido ou dirimido por algum dos membros do grupo. Neste caso, pode se fazer necessária a consulta de um ou mais especialistas, sendo o critério da escolha a situação, o projeto selecionado na etapa inicial e os objetivos escolares, ficando encarregados dessa definição os próprios componentes da equipe do projeto (no caso os professores e alunos).

4) Indo à prática: É o momento de "descer ao terreno", como denomina Fourez (1997, p.117). Esta etapa se caracteriza pelo aprofundamento no sentido de buscar informações concretas da situação e do projeto. Segundo Siqueira e Gaertner (2014, p.5), "é a fase mais aproximada do cotidiano, no qual pode haver: entrevistas, saídas de estudo, pesquisas, leituras, desmontar uma ferramenta tecnológica, entre outras práticas. Este é o momento em que saímos do abstrato e trabalhamos com o concreto".

5) Abertura aprofundada de algumas caixaspretas (CP) a fim de estabelecer descobertas de princípios disciplinares que fundamentam uma tecnologia: É o momento disciplinar da interdisciplinaridade, pois é possível nesta etapa que se possa trabalhar uma disciplina específica com certa profundidade ou ainda ter certos tópicos estudados brevemente. A abertura de CP pode ser realizada com ou sem a ajuda de especialista, sem que se esgote o conhecimento científico e "deve estar em última análise, condicionada ao contexto, ao projeto, aos produtores e destinatários da Ilha de racionalidade", como destaca Nehring et al. (2002, p. 12)

6) Esquematização da situação problematizada: É o momento da construção de uma síntese ainda parcial da Ilha Interdisciplinar de Racionalidade, relatando o que foi estudado e apontando as CP que poderão ser abertas. Siqueira e Gaertner (2014, p.5) destacam que a síntese "pode ser apresentada através de um desenho, mapa conceitual, vídeo, maquete, texto, resumo, enfim, algo que representa o que já foi conquistado".

7) Abertura de algumas caixas-pretas sem a ajuda de especialistas: Este é um momento de construção autônoma em que os estudantes podem ser estimulados para a abertura de caixas-pretas já listadas anteriormente sem a ajuda de peritos ou especialistas. Esta etapa é importante, pois é possível que os estudantes possam estabelecer modelos e construções, ainda que provisórios e aproximados, que tratam de temáticas do dia-a-dia, o que é interessante no âmbito educacional (NEHRING et al., 2002). Melhor ainda se considerarmos que os recursos tecnológicos (como: internet, revistas, livros etc.) atualmente disponíveis podem ajudar nessas aberturas e podem aguçar a curiosidade dos estudantes.

8) Produto final ou síntese da IIR produzida: A forma deste produto final pode ser um relatório, uma cartilha, um manual, um CD, um texto síntese etc. Nehring et al. (2002) observam que Fourez considera que 0 processo de síntese da llha se torna importante por inter-relacionar variados elementos. Destacam, ainda, a importância das respostas para as quatro questões: (a) $\mathrm{O}$ 
que é estudado contribui no sentido da negociação com o mundo tecnológico analisado?; (b) Produziu certa autonomia no mundo científico-técnico na sociedade em geral? (c) Em que termos os saberes adquiridos podem ajudar a discutir com maior precisão as decisões a serem tomadas? (d) Como isto proporciona uma representação de nosso mundo e história que seja capaz de permitir situar-nos melhor e facilitar uma maior comunicação com os outros?

Estas perguntas foram respondidas em debates em sala de aula e diferentes possibilidades de estudos foram apresentadas pelos alunos, considerando ainda $\mathrm{o}$ ano escolar $\mathrm{e}$ as temáticas. Os diversos e distintos saberes científicos e populares que se pode vislumbrar no espaço do Ver-o-Peso contribuem ainda para dinamizar e vivenciar o modo de vida do cidadão paraense considerando suas peculiaridades locais/ regionais.

\section{RESULTADOS E DISCUSSÃO}

As apresentações de excertos das oito sínteses ajudaram a construir uma sequência de como esses fenômenos foram observados na visita que os discentes realizaram ao mercado do Ver-o-Peso:

Equipe 1/2015: Nossa equipe realizou uma visita ao mercado do Ver-o-Peso que abastece a cidade com vários tipos de gêneros alimentícios (CP) e ervas medicinais (CP). Ao caminhar nos espaços do Ver-oPeso, notamos diversos preparos regionais, podemos observar com bastante frequência (CP) alguns que pode se dizer que são mais tradicionais como os cozidos (CP) de peixes, peixe com açaí (CP), pratos banhados no tucupi (CP), dentre outros que expressam claramente a cultura culinária paraense; outros produtos comercializados no Ver-oPeso é a farinha (CP) e a tapioca(CP) que é encontrada em forma de goma ou em grãos ambas extraídas da mandioca(CP) juntamente com o tucupi(CP) onde se utiliza ferramentas manuais como o Tipiti (CP) para extrair o tucupi e daí o preparo da farinha d'agua e da tapioca dentre outros. Outro aspecto notório são os sorvetes feitos de frutas exóticas e nativas (CP) das diversas regiões do estado e a comercialização de diversas frutas como o cupuaçu (CP), a graviola (CP), o açaí (CP), o muruci, entre outros, de todas essas frutas notamos que uma delas é mais comercializada que é o açaí fruta típica da região norte cujo o nome cientifico(CP) é Euterpe Oleracea (CP) fruto esse que é de uma palmeira(CP) conhecida regionalmente como palmeira do açaí (CP) de onde é extraído através de maquinários(CP) ou manualmente o vinho do fruto.

Equipe 3/2016: O Ver-o-Peso é cercada pela Bahia do Guajará (CP), fato que contribui para a atividade pesqueira (CP) na região, sendo um local de muito vento (CP) e com a presença de muitas embarcações. Entre as várias especiarias $(\mathrm{CP})$ que $\mathrm{O}$ mercado oferece estão os banhos de cheiro (CP), fragrâncias de ervas $(\mathrm{CP})$ e o óleo $(\mathrm{CP})$ de boto (CP), que segundo os vendedores "atrai quem a pessoa desejar".

Equipe 2/2016: No mercado é possível encontrar artigos processados (CP) artesanalmente (CP) como polpas (CP) de frutas (CP), bombons de chocolate (CP) com sabores de frutas regionais, tucupí (CP), farinha de mandioca (CP), farinha de tapioca $(\mathrm{CP})$, camarão salgado (CP) e uma série de outras especialidades da culinária regional como o jambú (CP) e maniva moída (CP). O misticismo (CP) também se faz presente na feira e é de grande atrativo para muitas pessoas, principalmente para maior parte da população paraense, que possui hábitos de utilizar os conhecimentos herdados das gerações anteriores (CP) à cerca do uso das ervas $\mathrm{CP}$ ) em banhos e rituais e também no tratamento de doenças. $\mathrm{O}$ artesanato $(\mathrm{CP})$ e a cerâmica $(\mathrm{CP})$ marajoara $(\mathrm{CP})$, que são itens bastante conhecidos no cenário nacional e internacional. É possível encontar também cuias (CP), "tipitis" (CP), brinquedos de mirití (CP) e uma grande variedade de produtos artesanais, além dos vasos de cerâmica produzidos nas diversas olarias (CP) do interior do estado. Não podemos esquecer de um dos mais importantes ícones da feira: o Mercado de Ferro, local onde são comercializadas toneladas (CP) pescado das mais variadas espécies (CP) predominantes nos rios da Amazônia. Todo o produto, permanece exposto nos balcões ou acondicionado em caixas térmicas (CP) e é conservado utilizando gelo (CP) ou por meio do "método de salga" (CP).

Equipe 4/2016: As lonas (CP) utilizadas para a proteção dos usuários e dos trabalhadores contra os raios ultravioletas (CP e a chuva (CP), encontravam-se péssimas condições, em virtude de múltiplos orifícios e a grande quantidade de sujeiras encontradas na mesma, podendo gerar doenças respiratória 
como a bronquite (CP); O trânsito ao redor do Mercado Ver-o-Peso é uma questão relevante, pois a ausência da faixa para pedestres e ciclovias pode colocar em risco a integridade física (CP) dos seus usuários. Alertando ainda para a poluição visual (CP) do entorno, pois a cidade assume um espaço de relações comerciais capitalista (CP), escondendo a sua arquitetura original (CP).

Equipe 1/2016: Outro setor muito visitado e o das ervas medicinais (CP) como, por exemplo, andiroba (CP), copaíba (CP), unha de gato (CP) o mastruz (CP) e outras, que dizem curar toda espécie de doenças (CP). Além disso, também encontramos lá os tão famosos "Cheiros" (CP) do Ver-o-Peso, que são muito apreciados pelos turistas. Na feira também existem uma infinidade de produtos naturais, tais como: sabonetes (CP), shampoos (CP), garrafadas (CP), além de cascas de pau (CP), como a verônica (CP) e barbatimão (CP), que segundo as crendices populares (CP) estas e outras infinidades de cascas possuem propriedades (CP) fitoterápicas (CP).

Equipe 4/2015: Segundo a informação de uma erveira (CP) uma parte da população amazônica adquiriu o hábito cultural (CP) de se realizar a aromatização (CP) do corpo ou de ambientes (CP) com estes produtos extraídos da floresta (CP). Alguns desses produtos são feitos por elas e outros pela população ribeirinha (CP) que fica próximo da capital paraense.

Equipe 2/2015: Além de todos os produtos que se pode encontrar no mercado, dos aromas (CP) e sabores (CP), não podemos deixar de falar nos sons (CP) que ecoam $(\mathrm{CP})$, se entrelaçando, seja das músicas ou da voz dos vendedores tentando atrair fregueses.

Equipe 3/2015: Toda essa diversidade fica próximo do mercado de peixes no qual encontramos grande variedade de tipos, como o Filhote (CP), a Pescada (CP), a Piramutaba (CP), o Tamuatá (CP), e as Ovas de peixes (CP), entre outros, onde é abastecido quase todos os dias, e também encontramos mariscos (CP) como o Camarão e o Caranguejo. E em suas proximidades encontramos Patos, Galinhas, Cordonas e outros. Ainda se falando de peixes notamos que o Pirarucu (CP) é comercializado em um setor fora do mercado, vendido já salgado, e que devido à semelhança de sabor é considerado o Bacalhau da Amazônia (CP).
Existe 0 setor de artesanatos onde encontramos objetos feitos com sementes regionais (CP), como as sementes de Tucumã, de Tento (CP), de castanha-do-pará (CP) e Anajá (CP).

A aprendizagem de conceitos científicos, neste contexto, ocorre no momento em que os estudantes procuram abrir as caixas pretas, com ou sem a ajuda de especialistas. Conceitos como condução, convecção e irradiação do calor, decomposição, soluções, $\mathrm{pH}$ e acidez e basicidade, entre outros, que são necessários à compreensão de fenômenos observados no mercado passam a ser estudados pelos alunos e expostos posteriormente em seus registros da atividade.

\section{CONSIDERAÇÕES FINAIS}

Os dois períodos de pesquisa convergem no sentido de apontar a riqueza observada no mercado do Ver-o-Peso como fonte de informações que associam o conhecimento científico ao conhecimento cotidiano e popular.

Esta convergência fica evidente quando se analisa a quantidade de fenômenos observados e relatados nas sínteses dos alunos (quatro sínteses na primeira etapa da pesquisa em julho de 2015 e quatro sínteses na segunda etapa da pesquisa em julho de 2016).

O desenvolvimento de ilhas Interdisciplinares de Racionalidade (IIR) em um ambiente propicio para esta estratégia possibilitou aos alunos a oportunidade de demonstração de competências inerentes a esta atividade, uma vez que os alunos, a partir de uma motivação inicial, determinaram a problematização, construíram visões prévias sobre o tema necessárias para o ponto de partida, definiram estratégias de trabalho, verificaram a aplicação dos conhecimentos em fenômenos observados no cotidiano de um contexto pré-definido, realizaram a aplicação destes conhecimentos, tornando-os significativos pedagogicamente e identificaram questões sociais decorrentes das atividades práticas no complexo do Vero-Peso.

Como o desenvolvimento de um IIR requer dos alunos competências e habilidades interdisciplinares esta atividade é uma oportunidade adequada para que estes aprendizes consigam dar significados para os 
conhecimentos apreendidos isoladamente em um sistema disciplinar e assim compreender as aplicações dos conhecimentos escolares e científicos dentro de um determinado contexto real.

Conclui-se, portanto, que esta estratégia educacional no Ver-o-Peso se apresentou como adequada para o planejamento de aulas que envolvam organização de conteúdos científicos por meio de estudo de temas, assim como a aplicação de Ilhas Interdisciplinares de Racionalidade, apoiada nas relações entre Ciência, Tecnologia e

\section{REFERÊNCIAS}

[1] Angotti, José A. P.; Auth, M. A. Ciência e Tecnologia: Implicações Sociais e o Papel da Educação. Ciência \& Educação, Bauru (sp), v.7, n.1, p. 15-27, 2001.

[2] Angotti, José A. P. Ensino de Física com tdic. Florianópolis: ufsc/ead/cfm/ced, 2015.

[3] Auler, D.; Bazzo, W.A. Reflexões para a Implementação do Movimento cts no contexto Educacional Brasileiro. Ciência \& Educação, v.7, n.1, p.1-13, 2001.

[4] Belém. Prefeitura de Belém. secretaria municipal de economia (secon). ver-o-peso completa 389 anos de história neste domingo. belém, 2016. disponível em http://www.belem.pa.gov.br/secon/site/2016/03/27/ ver-o-peso-completa-389-anos-de-historia-nestedomingo/

[5] Brito, I. P. de; Gomes, N.F. o Ensino de Física através de temas no atual cenário do Ensino de ciências. Encontro de Pesquisadores em Educação em Ciências, v. 6, 2007.

[6] Cachapuz, A. F. do Ensino das Ciências: seis ideias que aprendi. In: Carvalho, A.M.P. de; Cachapuz, A. F.; Gil-Pérez, D. (orgs.) O Ensino das Ciências como compromisso científico e social: Os caminhos que percorremos. São Paulo: Cortez, 2012.

[7] Esteban, M. S. E. Pesquisa Qualitativa em Educação Fundamentos e Tradição. Porto Alegre: artmed, 2010. 268p.

[8] Fourez, G. Alfabetización Cientifica y tecnolÓgica: Acerca de lãs Finalidades de la Ensenanza de Lãs Ciências. Buenos Aires, argentina. ediciones colihue, 1997. 249 p.

[9] Nehring, C.M.; Silva, C.C.; Trindade, J.A.O.; Pietrocola, M.; Leite, R.C.M.; Pinheiro, T.F. As ilhAs de Racionalidade e o Saber Significativo:
Sociedade (CTS), apresentou-se como uma alternativa na Educação em Ciências, no sentido de proporcionar considerações sobre a formação de cidadãos críticos, reflexivos, questionadores e conhecedores das características culturais de sua região e de conhecimentos científicos associados a sua realidade.

\section{AGRADECIMENTOS E APOIOS}

Aos alunos de Licenciatura em Ciências Naturais da UFPA.

O Ensino de Ciências através de projetos. Ensaio Pesquisa em Educação em Ciências, v.2, n.1, p. 118, março, 2002

[10] Pinheiro, T.F.; Pinho-Alves, J. Ilhas de Racionalidade: experiências interdisciplinares na segunda série do Ensino Médio. IN: Encontro Ibero-Americano de coletivos escolares e redes de professores que fazem investigação na sua escola, 4, 2005, Lajeado (rs). Anais... Lajeado (rs): 2005.

[11] Ricardo, E. C. Et Al. A Abordagem Cts e a Alfabetização Científica e Tecnológica: Conflitos e aproXimações. III Seminário Ibérico Cts no Ensino das Ciências, 2004.

[12] Santos, W. L. P. dos. Contextualização no Ensino de Ciências por meio de temas cts em uma perspectiva crítica. Ciência \& Ensino, campinas (sp), v.1, número especial, nov, 2007.

[13] Santos, W. L. P. dos; Schnetzler, R. P.. Educação em Química: compromisso com a cidadania. 4. ed. rev. atual. ijuí (rs): unijuí, 2010.

[14] Siqueira, Josiane Bernz; Gaertner, Rosinéte. Ilhas Interdisciplinares de racionalidade: conceito de proporcionalidade na compreensão de informações contidas em rótulos alimentícios. simpósio nacional de ensino e ciência e tecnologia (sinect), 4, 2014, Ponta Grossa (pr). Anais... Ponta Grossa (pr): Sinect, 2014.

[15] Sousa, R. G. Desafios, Potencialidades e Compromissos de uma experiencia Pedagógica para a formacão cidadã: prática cts construida a partir de uma ilha interdisciplinar de racionalidade sobre reciclagem do lixo urbano. 2007. 196f. Dissertac,ão (Mestrado em Educac,ão em Ciéncias e Matemáticas) - Núcleo Pedagógico de Apoio ao Desenvolvimento científico, Universidade Federal do pará. Belem, 2007. 


\section{Gapítulo 14}

\section{ESTRATÉGIAS DE ENSINO PARA A CONSTRUÇÃO DE PRODUTOS TECNOLÓGICOS MEDIANTE IMPLEMENTAÇÃO DE RESIIDUOS SÓLIDOS}

\section{Jakeline Amparo Villota Enríquez}

Maribel Deicy Villota Enríquez

"Quienquiera pueda cultivar dos espigas de trigo o dos briznas de hierba en un trozo de tierra donde antes crecía una sola, merecería mayor agradecimiento de la humanidad que toda la estirpe de políticos juntos." El Rey de Brobdingnag, en Los Viajes de Gulliver, la clásica novela satírica de Jonathan Swift

Resumo: Este estudo consistiu em descrever as estratégias utilizadas pelas professoras em formação para a elaboração de produtos tecnológicos mediante a implementação de garrafas e tampas. o contexto foi a instituição educativa policarpa bocas de Telembí. A metodologia utilizada nesta pesquisa foi qualitativa, coletando os dados através da observação participante no que se utilizou um diário de campo, ademais de ferramentas pedagógicas tais como filmes. Os resultados preliminares mostraram a existência de diferentes estratégias utilizadas pelas professoras para a elaboração de produtos tecnológicos mediante o uso de garrafas e tampas plásticas. Cada estratégia utilizada pelas professoras foi intencionada e faz parte da representação do universo pedagógico na criação dos produtos tecnológicos.

Palavras chave: Estratégias de ensino, formação de professores, produtos tecnológicos. 


\section{INTRODUÇÃO}

Desde tempos antigo a tecnologia esteve presente no cotidiano dos seres humanos, pois frequentemente diversos elementos tecnológicos ajudaram na reconstrução social, política, econômica e culturas de distintas sociedades y grupos étnicos, onde a tecnologia atravessou o comportamento do homem. Encontramos atualmente nas diferentes atividades que realizamos, objetos como liquidificador, geladeira, televisão e demais; elementos aperfeiçoados com o passo do tempo e incluso produto da reflexão de modernidade que gira ao redor do tecnológico Bem o expressava Bernardo Chartres (1676):

«Somos como anões sentados nos ombros dos gigantes para olhar mais coisas que eles e ver mais longe, não porque nossa visão seja mais nítida ou nossa estatura maior, senão porque podemos elevar-nos mais alto graças à sua estatura de gigantes».

Está metáfora descritiva de Chartres em relação com a modernidade, dilucida a relação tecnológica com os indivíduos, onde o meio ambiente inserido na cotidianidade joga um papel fundamental na produção do que hoje se conhecem como resíduos sólidos. Assim de acordo com Santambrosio (2001, p.53):

A tecnologia atual para cumprir os objetivos destinados a reduzir a quantidade de resíduos derivados das atividades aumentou a proporção de materiais reutilizados no processo de produção e o aumento da reciclagem de resíduos em outros destinos simplificou a tarefa de corrigir aqueles que finalmente eles devem ser descartados.

Nesta relação, o meio ambiente está ligado à tecnologia, especialmente aos objetos tecnológicos. É essencial entender então a relação que se tece frente ao conhecimento ambiental e tecnológico onde este seja projetado, bem seja através do seu comportamento, na sociedade, com a natureza, formando e educando sobre a concepção integral do ser humano ou seu entorno. No entanto, a problemática da reutilização dos resíduos sólidos não está isolada no campo educativo, em particular no processo de ensino e aprendizagem, pois é a partir daqui, o professor pode realizar atividades de conscientização sobre o uso de resíduos sólidos.

Dentro do processo de conscientização, podemos levar o sujeito a imaginar e criar diferentes elementos que fazem parte do seu cotidiano, como por exemplo os produtos tecnológicos, os quais, estão presentes na tecnologia que implementa atualmente. Em outras palavras, esta manipulação de resíduos sólidos gera motivação para a criatividade e a inovação tanto do aluno como do professor, a fim de que se desenhe elementos que sem dúvida fazem parte do ambiente escolar e da prática pedagógica.

O acima, leva o professor a usar diferentes estratégias para que o aluno possa manipular aqueles materiais que pensamos serem inúteis e assim poder reutilizá-los adequadamente. As estratégias utilizadas pelo professor são ferramentas que tentam ajudar ao aluno no processo de aprendizagem sobre diferentes conceitos estabelecidos nos planos curriculares.

Em relação no anterior, surge a seguinte questão que direcionará este estudo: Que estratégias utilizam as professoras em formação para a elaboração de produtos tecnológicos através da implementação de garrafas e tampas de plástico? Assim, este estudo consistiu em descrever as estratégias implementadas pelas professoras em formação para a elaboração de produtos tecnológicos mediante a utilização de garrafas e tampas de plástico. A continuação, apresentaremos alguns elementos conceituais que nos ajudarão a entender nosso objeto de estudo.

\section{CONCEPTUALIZAÇÃO SOBRE ESTRATÉGIAS DE ENSINO}

O conceito de estratégia foi tratado por diferentes autores iniciando com Alejandro Magno (356-323 a.c.), seguidamente Aníbal (249-183 a.c.), Escipión o Africano (236-184 a.c.), Julio César (100-44 a.c.), também Federico o Grande (1717.1786) e Napoleón (1769-1821), depois, Carlos Von Clausewitz (1780-1813) quem o incorporou em sua obra "De la guerra", a qual tem 8 livros, definindo-a como "el arte de los generales" (Villota \& Riascos, 2017).

Assim, no final do século I e no início do II a.C, o conceito de estratégia foi focado na barbárie e sujeição militar para deslocar os judeus da Babilônia por Ciro, o conquistador. 
No século IV a.C a estratégia se refletiu nas táticas e no uso das forças armadas para vencer e destruir o Império Persa pelos babilônios. Seguidamente, no século $V$ a.C particularmente no Ocidente, os gregos como: Heródoto, Jenofonte e Sócrates usam a palavra estratos-ago, que significa "exército" e "eu conduzo". No entanto, em oriente no século VI a.C Sun Tzu, vincula o termo estratégia com "astúcia e cálculo", tornandose no primer escritor que implementou a palavra estratégia em seus livros. Mais tarde, no século XII d. C., as estratégias foram utilizadas no campo militar e religioso, já que passava pelas cruzadas promovidas pelo Papa Gregório sétimo, com o objetivo de conseguir terra para a igreja. No século XVIII, este conceito de estratégias está ligado à política gerando estratégias políticas e no final do século $X X$, integrando-se no ambiente escolar. No campo educativo, a estratégia é entendida como um conjunto de atividades desenhadas para alcançar de forma eficaz e eficiente a consecução dos objetivos educacionais esperados (Villota, 2016).

Deste modo, as estratégias foram integradas no processo de ensino e aprendizagem, pelo que temos estratégias de ensino e aprendizagem; no entanto, neste estudo, nos centraremos nas estratégias utilizadas pelo professor; ou seja, estratégias de ensino. Consequentemente dentro desta pesquisa, assumiremos o conceito de estratégia como aquele conjunto de orientações que dá o professor com o objetivo de que aluno explore uma determinada situação de ensino; ou seja, são orientações que o professor oferece ao aluno com o objetivo de desenvolver uma determinada tarefa relacionada com a temática do desenvolvimento de produtos tecnológicos (González, Villota \& Agredo, 2017, Villota et al., 2017).

As estratégias de ensino influenciam o processo de aprendizagem do aluno entre eles na construção de seus valores, conteúdos culturais, científicos, etc., que estão imersos na situação de classe e fora do mesmo; pelo que, Anijovich \& Mora (2009) argumentam que as estratégias utilizadas pelo professor devem estar relacionadas a um processo de reflexão com o propósito de realizar um análise não só sobre as temáticas abordadas em aula, senão da forma como nós como professores estamos abordando ditas temáticas.

Em relação com o anterior, Kolher (2005) citado por Villota, Villota \& Ogécime (2016, p.54) afirma que "as estratégias de ensino são ferramentas que têm os professores têm para promover e atingir os objetivos estabelecidos dentro de qualquer atividade fornecida a seus alunos, principalmente aqueles de seu desenvolvimento intelectual". Em outras palavras, as estratégias de ensino são parte integrante da prática pedagógica do professor e tentam fortalecer o processo de aprendizagem do aluno, servindo como mediadores entre os conteúdos e a maneira de abordá-los.

De fato, Díaz \& Hernández (2007) afirma que as estratégias de ensino são procedimentos (conjuntos de operações ou habilidades), utilizados pelo professor de forma consciente, controlada e intencional como instrumentos flexíveis para ensinar significativamente e resolver problemas. Os procedimentos ligados às estratégias de ensino devem ter certas características, por exemplo; coerência, consistência, argumentação entre outros, que ajudam a fortalecer a estrutura dos procedimentos.

Por outro lado, Anijovich \& Mora (2009, p. 4) definem estratégias de ensino como "o conjunto de decisões tomadas pelo professor para orientar o ensino, a fim de promover a aprendizagem de seus alunos". Em outras palavras, o objetivo principal das estratégias de ensino gira em torno da aprendizagem dos alunos, ou seja, o aluno é o protagonista do processo de aprendizagem.

Assim, Díaz \& Hernández (2007) e Anijovich \& Mora (2009) são autores que se complementam, dado que, através do processo referente a procedimentos conscientes, o professor deve tomar diferentes decisões para manter a coerência, consistência, argumentação e outros elementos que estão ligados aos procedimentos conscientes. No entanto, Anijovich \& Mora (2009) permeia as estratégias de ensino no processo de aprendizagem das crianças observando-as como os principais autores de sua aprendizagem.

Consequente, Acosta \& García (2012) definem estratégias de ensino como ajudas propostas pelo professor, as quais, se proporciona-lhe ao aluno com o fim de propiciar o processamento de informações sobre os conteúdos estabelecidos nos planos curriculares. Assim, as ajudas que o professor brinda ao aluno pode ser tratada através de analogias, dicas, interação com estudantes, 
entre outros, que tentam fortalecer o processo de apropriação dos diferentes conceitos. No entanto, essas ajudas podem ser tão amplas que as fronteiras não sejam visíveis para o aluno, por exemplo; o desenvolvimento de uma tarefa, a ajuda pode ser o desenvolvimento da tarefa através da qual o aluno pede e o professor imediatamente dá a resposta, restringindo a possibilidade de explorar e que ele mesmo seja quem encontre a solução à tarefa estabelecida.

De forma contraria, Villota, Oliveira e González (2017) afirmam que as estratégias são orientações estabelecidas pelo professor para desenvolver uma determinada situação de aprendizagem, pelo que se limita estas ajudas às orientações que se dão mediante a interação dos estudantes, com o propósito de estimular ao mesmo à construção dos diferentes conceitos; ou seja, as estratégias de ensino são elementos que o professor têm em suas mãos para implementar na sua prática pedagógica tornando-se essas pontes mediadoras entre os conceitos e a maneira de abordá-los com os alunos; tendo presente que a implementação das estratégias vai além de uma utilização das mesmas; ou seja, cada estratégia tem uma intenção por parte do professor.
De fato, Acosta \& García (2012) e Villota, Oliveira e González (2017) são posições que estão relacionadas à análise de estratégias de ensino, por um lado, como ajudas e, por outro lado, como orientações que o professor oferece aos alunos. No entanto, deve-se ter cuidado com o uso dos termos "ajuda" e "orientar" posto que, apesar de que em vários casos eles são usados como sinônimos, esses autores não o assumem dessa maneira; já que o orientar limita diferentes ações e / ou fatos que o aluno desempenha para resolver uma determinada situação de ensino proposta pelo professor. Em quanto, "ajudar" dá liberdade, por isso vai além do acompanhamento e orientação das diferentes situações de ensino propostas ao aluno propiciando e / ou caindo o professor em realizar a mesma.

Em relação com o anterior, Villota (2016) manifesta a relação entre as estratégias de ensino, a tarefa a ser desenvolvida e o professor-aluno; reconhecendo que, para atingir o objetivo de uma determinada situação de ensino, necessita-se a coexistência da relação professor-aluno, tal como se apresenta a continuação:

Figura 1: Relação do profesor e estudante gerando estratégias para lograr o objetivo da tarefa.

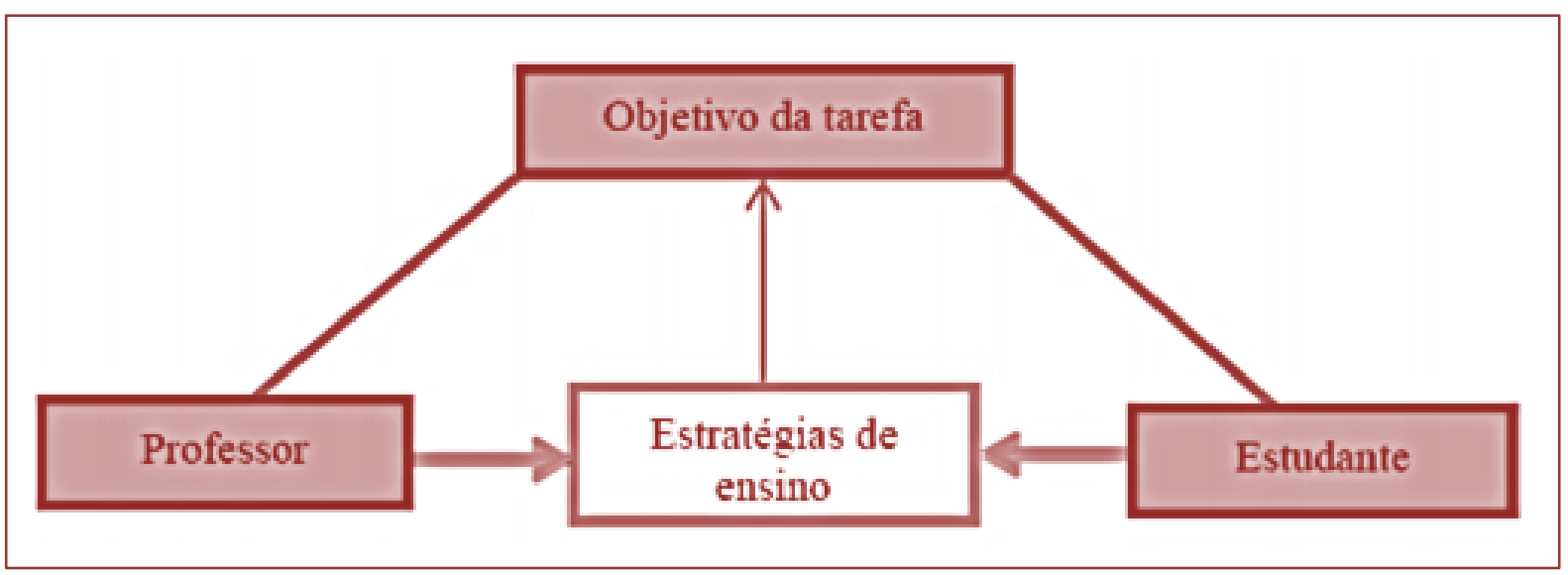

Fonte: Villota (2016)

Por outro lado, cabe ressaltar que existem diferentes classificações sobre as estratégias de ensino, particularmente neste estudo abordaremos a categorização proposta por Díaz \& Hernández (2010), quem, de fato, as classifica de acordo com o momento da implementação e sua respectiva apresentação em três grupos, que são: Pré- instruccionais, Co-instruccionais e Pósinstruccionais. Consequentemente, Díaz \& Hernández (2010, p.81) argumentam que:

As estratégias pré-instrucionais geralmente preparam e alertam o aluno em relação ao que e como ele/ela vá aprender (ativação de conhecimentos e experiências previas pertinentes) e permitir-lhe localizar-se no 
contexto de aprendizagem relevante. Algumas das estratégias pré-instrucionais típicas são: os objetivos e o organizador prévio. As estratégias de co-instrucionais apoiam os conteúdos curriculares durante o próprio processo de ensino ou a leitura do texto didático. Eles cobrem funções como as seguintes: detecção da informação principal; conceituação de conteúdos; delimitação da organização, estrutura e inter-relações entre os referidos conteúdos e manutenção da atenção e motivação. Aqui você pode incluir estratégias como: ilustrações, redes semânticas, mapas conceituais e analogias, entre outros. Por sua vez, estratégias pós-instrucionais são apresentadas após do conteúdo a ser aprendido e permitem ao aluno formar uma visão sintética, integrada e até crítica do material. Em outros casos, eles permitem avaliar sua própria aprendizagem. Algumas das estratégias de posinstruccionais mais reconhecidas são: pósperguntas intercaladas, resumos finais, redes semânticas e mapas conceituais.

Particularmente, nestas estratégias de préinstrucionais, refere-se às estratégias utilizadas pelo professor antes de iniciar o desenvolvimento do conteúdo da tarefa relacionada ao desenvolvimento de produtos tecnológicos. As estratégias de coinstrucionais são aquelas que o professor usa durante o desenvolvimento da tarefa. As estratégias pós-instrucionais são utilizadas pelo professor após o aluno ter experimentado a tarefa.

\section{ESTRATÉGIAS DE ENSINO E DESENVOLVIMENTO DE PRODUTOS TECNOLÓGICOS}

A lógica que define o melhor entendimento dessa sessão do presente trabalho nos leva introduzir o termo da "tecnologia", o contextualizando como conceito nuclear do mesmo.

De uma concepção de desenvolvimento sustentável, a tecnologia é identificada como um determinante ou condicionante tradicional do poder na forma de conhecimento que transforma recursos e materiais disponíveis. A este propósito, J. Beckmann (1846) a entende, no seu primeiro contexto mais moderno, como a ciência que ensina como tratar os produtos naturais e o conhecimento dos ofícios, em vez de mostrar unicamente os escritórios e como se devem seguir as instruções e os hábitos dos mestres para fabricar uma mercadoria, a tecnologia dá ensinamentos profundos e seguindo uma sistemática". (SALDANHA, apud FRANTZ, 2002, p.33).

Para as economias globais atuais, outros conceitos surgiram com diferentes abordagens, realçando outras dimensões. Para CASTELLS, se baseando nas perspectivas de Harvey Brooks e Daniel Bell, a tecnologia é "o uso de conhecimentos científicos para especificar as vias de se fazerem as coisas de uma maneira reproduzível" (2016, p. 89). Para a perspectiva que segue o presente trabalho, o termo da "tecnologia" se focaliza, a partir da consideração anterior, na questão que está diretamente relacionada à criação de conhecimento cujo contributo é indispensável para a inovação tecnológica para a solução de problemas.

Em 2014, a União Europeia apresentou seu 7응 Programa de Ação Ambiental (PEA) "Vivendo bem, dentro dos limites do nosso planeta", visando orientar a política ambiental europeia (INFO.BRUXELAS, 2015). Um dos elementos desta política ambiental é a Educação para o Desenvolvimento Sustentável (EDS), que deve ser fundamental na educação e formação com o objetivo de:

"Fornecer a todos os cidadãos europeus o conhecimento, habilidades e atitudes necessárias para compreender e enfrentar os desafios e as complexidades da vida moderna, levando em consideração as implicações ambientais, sociais, culturais e econômicas e, assim, assumir suas responsabilidades globais" (UNESCO, 2015, p.12)

Dessa forma, entende-se que o papel da Educação no desenvolvimento sustentável e na proteção do meio ambiente é fundamental. Assim, para contribuir para o desenvolvimento sustentável e atuar conscientemente para este propósito, é imperativo redirecionar a educação e a aprendizagem para que todos tenham a oportunidade de adquirir conhecimento, habilidades, valores e atitudes.

Supõe-se que as universidades e escolas de engenharia formam os alunos que serão os futuros tomadores de decisão das empresas nas quais terão de definir e gerenciar 
estratégias que integram o desenvolvimento sustentável. Pois, os alunos devem ter uma visão global desse conceito e também devem ser capazes de fornecer respostas específicas aos problemas ambientais, sociais e / ou econômicos de acordo com suas atividades nas empresas. As universidades e as escolas de engenharia devem promover na capacitação dos alunos uma ampla visão de desenvolvimento sustentável e elementos técnicos em relação às especificidades de cada curso (ecodesign ${ }^{4}$, eco-materiais, eficiência energética, economia circular, etc.).

Para este fim, as estratégias de ensino devem resultar em um modelo de Educação capaz de estabelecer conexões entre conhecimento, comportamentos e a realidade do desenvolvimento sustentável, a fim de melhorar seu pensamento complexo com visões prospectivas e visuais sistêmicas dos problemas para resolver.

Com base nesse objetivo, o ensino superior deve se centrar na integração do desenvolvimento sustentável em diversas ciências. Por isso, várias universidades, no mundo, oferecem ferramentas de ensinos para que possam integrar melhor a Educação de Desenvolvimento sustentável nos seus programas (MUSSET, 2010). Um dos objetivos é que os estudantes de diversas áreas e disciplinas possam adquirir cada vez mais habilidades transversais e uma visão sistêmica necessária para entender, de um ponto de vista ambiental, certos fenômenos, problemas ou soluções e suas consequências em um sentido amplo num contexto científico, técnico, econômico, jurídico e social.

As opções tecnológicas propostas também enfatizam a evolução de certos processos e atividades na condução de projetos tecnológicos devido à aparência de novas abordagens ou restrições relacionadas ao

\footnotetext{
${ }^{4}$ Ao longo do material, refere-se ao termo "ecodesign" todo o processo que contempla os aspectos ambientais onde o objetivo principal é projetar ambientes, desenvolver produtos e executar serviços que de alguma maneira consistem reduzir o uso dos recursos não renováveis ou ainda minimizar o impacto ambiental dos mesmos durante seu ciclo de vida. Isto significa reduzir a geração de resíduo e economizar custos de disposição final. É, também, qualquer atividade que, ligando o tecnicamente possível com o ecologicamente necessário, faz nascer novas propostas que sejam social e culturalmente aceitáveis.
}

desenvolvimento sustentável (MUSSET, 2010). Da mesma forma, os novos ciclos da faculdade também permitem repensar currículos de capacitação e treinamento. Desta maneira, cabe ressaltar a referência estabelecida pelo Ministério da Educação Nacional da Colômbia, onde se menciona que o ensino da tecnologia deve levar a dotar um comportamento ético e responsável; desenvolver boas práticas no uso de dispositivos de comunicação; analisar o impacto ambiental de um objeto e seus componentes e analise o ciclo de vida de um objeto (VILLAMIL; GUERRA, 2009) .

Reconhece-se que a construção progressiva desta cultura de desenvolvimento sustentável passará por uma fase de educação, capacitação e conscientização a montante de escolas de engenharia e universidades, para que nossas empresas se envolvam de forma eficiente em uma transição industrial inovadora. A essa contribuição, o presente trabalho exemplifica um possível panorama das evoluções a serem realizadas hoje nos sistemas educacionais para que os futuros engenheiros ou técnicos tenham capacidade para apreender os conceitos desenvolvimento sustentável e de eco-design e eco-inovação.

O objetivo de uma estratégia de ensino deste escopo consiste em realizar uma reflexão global sobre uma formação contínua de ensino superior com o objetivo de propor uma abordagem e ferramentas para ajudar professores a construir módulos e ofertas de treinamento que ajudam os alunos a adquirir progressivamente habilidades em desenvolvimento sustentável e, em particular, em design ecológico.

Durante muitos anos, muitos países colocaram uma forte ênfase na Educação para o Desenvolvimento Sustentável (EDS) nos currículos escolares (UNESCO, 2015. Assim, em uma idade precoce e ao longo de seu curso de formação, os alunos são chamados a compreender questões ambientais, econômicas e sociais e a serem capacitados em empreendedorismo e outros campos relativos à tomada de decisões (VILLAMIL; GUERRA, 2009). As experiências resultantes deste trabalho e as injunções institucionais que ele abarca nos indicam que para adquirir essas habilidades não se deve considerar a Educação como uma nova disciplina, mas como uma integração além das disciplinas que requer a criação de uma nova organização de disciplinas existentes (MUSSET, 2010). De acordo com 
PERPIGNAN; ROBIN; GIRARD (2016, p. 3), esta nova organização deve ser desenvolvida em torno de pelo menos cinco questões principais:

1. Analisar os laços entre conhecimento e ação, incentivando atividades pedagógicas focando na ação do aluno. Favorecer o projeto e estudar situações e/ou eventos reais. Durante essas atividades, as disciplinas que atingem os objetivos estabelecidos devem ser combinadas. O perigo é ser superficial e permanecer em uma lógica de bom senso porque os alunos podem estar muito focados na ação e menos na reflexão.

2. Identificar os valores e a ética que são fundamentais para o desenvolvimento sustentável: solidariedade, abertura, justiça, igualdade e responsabilidade. Durante a tomada de decisões e na ação, esses valores geralmente geram conflitos com outros, como lucro, prazer individual ou a preservação de conquistas pessoais.

3. Desenvolver um pensamento complexo. As publicações relativas ao pensamento complexo se concentram, frequentemente, no desenvolvimento de competências sistêmicas. Essa habilidade consiste em descrever um sistema de acordo com várias dimensões ou um diagrama e usar essa representação para formular possíveis ações pessoais.

4. Desenvolver a capacidade de construir o problema que os alunos precisam trabalhar. Os objetivos são fornecer aos alunos métodos, abordagens e ferramentas para analisar as situações que enfrentam e aprender a se questionar de forma crítica e reflexiva no mundo real problemático. A reflexão centra-se na escolha da situação-problema, a controvérsia, o debate e a inserção num paradigma.

5. Desenvolver um pensamento prospectivo, ou seja, ter a capacidade de imaginar não um futuro, mas diferentes futuros possíveis. O desenvolvimento do pensamento prospectivo exige que a sociedade leve em consideração o risco, a incerteza ou o conceito de prospectivo. $\mathrm{O}$ pensamento prospectivo também se refere à noção de livre arbítrio que deve ser implementada durante a escolaridade dos alunos como uma dimensão necessária para justificar o desenvolvimento sustentável e ter a capacidade de agir.
Para implementar estas cinco principais questões e tornar a "Educação de Desenvolvimento Sustentável (EDS)" eficiente, a organização das disciplinas e o lugar da EDS devem ser construídos e refletidos da escola primária para a universidade. Os alunos devem ser informados dessas questões e conceitos o mais cedo possível (UNESCO, 2012). O objetivo é ajudá-los a adquirir gradualmente a maturidade e uma certa profundidade de reflexão sobre o desenvolvimento sustentável.

Em 2008, as primeiras noções de desenvolvimento sustentável aparecem no programa universitário da Colômbia (VILLAMIL; GUERRA, 2009). O eco-design é uma dessas noções e é um elemento da educação tecnológica. O eco-design é considerado como uma sucessão de conhecimentos a serem aprendidos sem qualquer ligação entre processos de fabricação, propriedades do material, energia, uso ou disposição de um produto.

As opções tecnológicas "criação e inovação tecnológica" e "ciências da engenharia" oferecidas nos currículos são centradas na gestão de projetos tecnológicos destacando inovações que respondem a questões societárias respeitando os novos constrangimentos ou padrões de sustentabilidade. Em algumas escolas e nas universidades, os alunos têm a oportunidade de integrar cursos de ciência e tecnologia baseados na indústria que evoluíram para promover a aquisição de habilidades tecnológicas transversais em todas as indústrias e para trazer conhecimentos extensivos em um campo específico.

Neste modelo de Educação, o aluno está focado em adquirir uma cultura técnica com uma abordagem global de sistemas tecnológicos múltiplos e complexos (MUSSET, 2010). O design ecológico é apresentado como um conceito que integra múltiplos aspectos do complexo design de produtos e sistemas e considerações ambientais. O objetivo é criar soluções sustentáveis que atendam às necessidades e desejos humanos. Em alguns países, a ideia é que os alunos não só devem saber como reciclar ou separar o lixo, mas também aprender a entender como eles podem produzir menos desperdício e assim reduzir o consumo de energia criando uma tecnologia mais limpa (UNESCO, 2012). 
Os impactos econômicos, sociais e éticos geralmente não são estudados porque se referem a disciplinas não técnicas e os professores não são treinados nisso. Atualmente, poucos professores, não inicialmente treinados neste campo, podem oferecer módulos de treinamento em ecodesign que levem em conta todas as questões do desenvolvimento sustentável (UNESCO, 2012). Os cursos de concepção e soluções ecológicas geralmente levam a uma cultura técnica abrangente e superficial que integra restrições do desenvolvimento sustentável.

Por tanto, ao contrário das faculdades e escolas secundárias, as universidades e escolas de engenharia não possuem ou possuem poucos programas de capacitação criados pelas autoridades estatais (UNESCO, 2012). Por conseguinte, os programas de formação são frequentemente construídos com base nas necessidades expressas pelo domínio (ou seja, no mundo socioeconômico) e nas normas ou leis, métodos e / ou abordagens aplicadas nas empresas (PNUD, 2015). Assim, a concepção ecológica é muitas vezes apresentada como uma abordagem preventiva que integra o fator ambiental no design de produtos e serviços que visa reduzir os impactos ambientais de produtos e serviços ao longo de seu ciclo de vida, preservando ou melhorando qualidades de uso destes.

De fato, o objetivo é divulgar as interdependências entre cada objetivo/dimensão para ajudar os alunos a adquirir um pensamento complexo, avançar e entender o valor de ter uma visão sistêmica dos problemas. As universidades e escolas de engenharia, muitas vezes, complementam esta visão um tanto "teórica" do eco-design com uma visão mais "técnica", baseada em cursos referentes a métodos e ferramentas usados nas empresas (UNESCO, 2012). Os diferentes usos dessas ferramentas de ecodesign criam especificidades na capacitação de eco-design entre instituições. Pois, não há apenas uma maneira de abordar e fazer o design ecológico em universidades e escolas de engenharia.

\section{CONTEXTO DA PESQUISA}

Nesta seção, apresentaremos o contexto onde foi desenvolvida esta pesquisa, o qual, nos ajudará a fortalecer o mesmo. Assim, este estudo foi realizado na Instituição Educativa Policarpa, localizada no corregimento Bocas de Telembi, pertencente ao município de Roberto Payan (San José), Departamento de Nariño. Especificamente na Instituição Educacional Policarpa. $\mathrm{Na}$ implementação das tarefas participaram duas professoras em formação, as quais atualmente estão vinculadas ao programa de Bacharelado em Licenciatura em Educação Básica com ênfase em Tecnologia e Informática e Bacharel em Licenciatura em Educação Básica com ênfase em Ciências Naturais da Universidade Santiago de Cali, Colômbia. Além disso, as pessoas que participaram na implementação das tarefas foram estudantes da Instituição e parentes pertencentes aos distritos vizinhos. A continuação, mostraremos a localização da Instituição Educativa Policarpa.

Roberto Payan está localizado no centro e ocidente do Departamento de Nariño, a Sur este de Colômbia, na zona tórrida por acima da línea equatorial. É uma região montanhosa, cujo território pertence à zona do pacífico. 


\section{1}

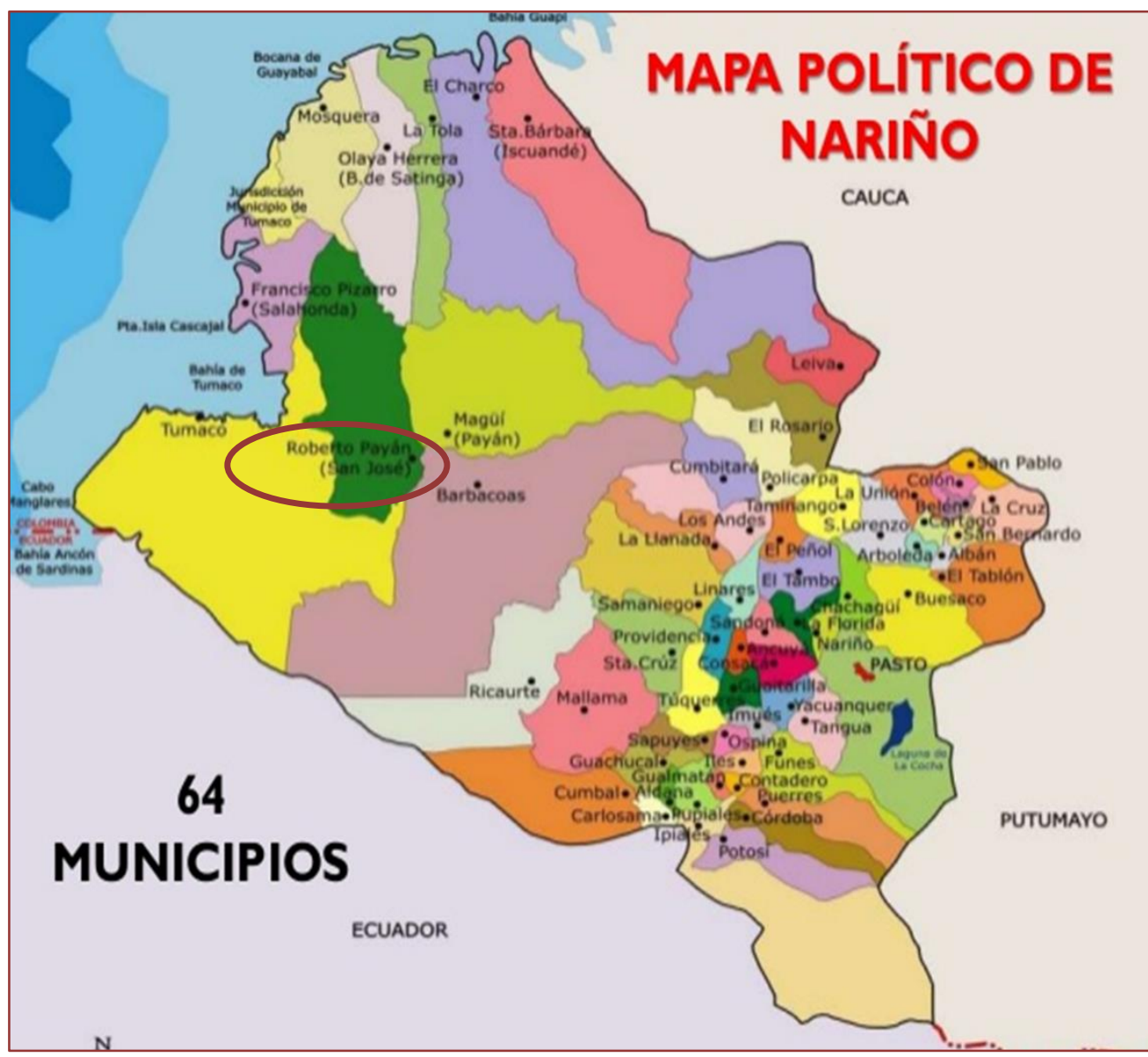

Fonte: Manuel de la alcaldía de Policarpa (s. f.).

Referente, à população da comunidade a grande maioria são afrodescendentes, por isso tem uma amostra de expressões culturais, que se tornam um legado importante para as gerações futuras. Nesses espaços, as pessoas exibem sua cultura através das danças tradicionais com "o bale típico do currulao", os pratos típicos, as celebrações de festivais tradicionais como carnavais, dia afrocolombiano, festividades patronais que são o dia 15 de agosto da mineria tradicional, artesanato, entre outros. A continuação apresentaremos a Instituição Educativa Policarpa:

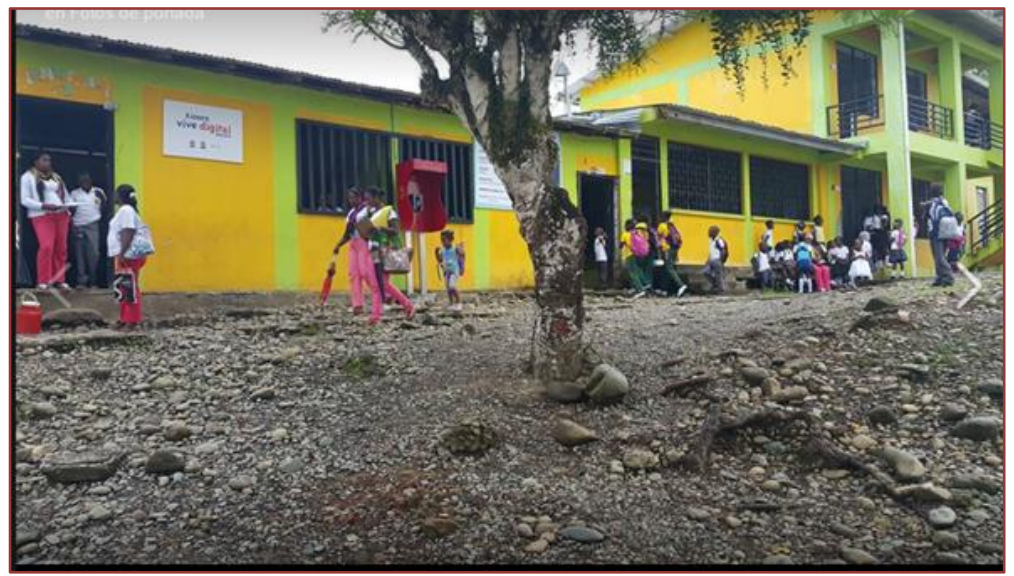

Fonte: Manual de la alcaldía (2010) 


\section{METODOLOGÍA DA PESQUISA}

O objetivo desta pesquisa foi descrever as estratégias implementadas pelas professoras em formação para a elaboração de produtos tecnológicos mediante a utilização de garrafas e tampas plásticas, pelo que, o método a ser implementado neste estudo foi qualitativo, posto que é descritivo e gera características qualitativa ligada às estratégias de ensino utilizadas para a elaboração de produtos tecnológicos Creswell (2007). Consequentemente, os instrumentos implementados para a coleta de dados foram a observação, que foi abordada através de vídeos, fotos e caderno de campo, ou seja; 1) filmagem das aulas nas que abordasse tópicos relacionados à reutilização de resíduos sólidos, 2) Realizar diferentes anotações no caderno de campo sobre as estratégias de ensino, 3) Tirar fotos sobre os momentos em que foram implementadas diferentes estratégias de ensino.

Em relação ao tipo de estudo, esta pesquisa enquadra-se na pesquisa-ação, pois permitiu identificar e destacar as diferentes estratégias utilizadas pelas professoras em formação para a elaboração de produtos tecnológicos. Desta forma, Lewin citado por Restrepo (2005, p.159) concebe a pesquisa-ação como:

a empreendida por pessoas, grupos ou comunidades que realizam uma atividade coletiva para o bem de todos, consistindo em ema prática reflexiva social na que interatuam a teoria e a prática com miras a estabelecer mudanças apropriados na situação.

\section{APRESENTAÇÃO DE DADOS}

As situações apresentadas foram conformadas em relação à fala e ações das professoras em formação Kelly e Nelcy durante o desenvolvimento de cada tarefa em relação à produção de produtos tecnológicos através de resíduos sólidos, que foram desenvolvidos na sala de aula. As falas das participantes se apresentarão em sua língua nativa; ou seja, em espanhol. É importante ressaltar que alguns elementos que utilizaremos hão sido abordados em estudos realizados por Villota, Villota \& Ogécime (2016, p. 58):

Alguns dos elementos utilizados durante a transcrição dos dados são tratados nos trabalhos de Brum-de-Paula e Espinar. No entanto, os outros são adaptados para apoio a transcrição. Entre estes elementos, temos vários códigos, tais como: 1) A informação dentro de parênteses que indicam uma ação dos participantes ou explicações de sua maneira de falar. 2) 0 símbolo "..." Para mostrar uma ideia ou palavra.

Além desses códigos, cada linha da transcrição foi enumerada a partir de (1), para facilitar precisamente a localização quando é referenciada. No entanto, antes de cada numeração, atribuímos uma carta para identificar quando são relatados na linha, ou seja, a letra $\mathrm{O}$ é atribuída às linhas registradas durante a observação dos professores no desenvolvimento de tarefas. Assim, a primeira linha de cada episódio de transcrição é iniciada por (O1); o segundo por (O2); e assim por diante.

Desta forma, a apresentação dos nossos dados será realizada através de três conjuntos de situações, em que cada um deles demarca a categorização proposta por Díaz \& Hernández (2010). Ou seja, o conjunto de situações 1 corresponde às estratégias Pre-instrucionais; seguidamente, no conjunto de situações 2, localizaremos as estratégias de Co-instrucionais e, posteriormente, no conjunto de situações 3, localizaremos as estratégias Pós-instrucionais; com a finalidade de identificar, descrever e classificar as estratégias utilizadas pelas professoras em formação.

\subsection{CONJUNTO DE SITUAÇÕES 1: ESTRATÉGIAS PRE-INSTRUCCIONAIS}

Neste "conjunto de situações 1", localizamos as estratégias utilizadas pelas professoras em formação durante a abertura da tarefa a ser desenvolvida. Consequentemente, "a exploração de conceitos" foi uma estratégia de ensino utilizada pelas duas professoras em formação, que consistiu em abordar o conceito de meio ambiente, ponto ecológico entre outros; com o propósito de ativar os conhecimentos prévios dos alunos. A continuação, se apresenta a implementação desta estratégia de ensino: 
Quadro 1. Estrategia de ensino "Exploração de conceitos"

\title{
Momento da implementação
}

(O1) Kelly: ¿Después de sacar las botellas de la talega, podría alguien decirme que entiende por residuo solido?

(O2) Estudiante: ¿Las botellas?

(O3) Kelly: Si, pero algo mas halla de eso. ¿Alguien sabe?

(O4) Estudiante: Un material que se puede volver a utilizar, como, por ejemplo, ¿las bolsas de la leche?

(O5) Kelly: Muy bien, es decir, que las botellas y las tapas son residuos sólidos. Ahora vamos a trabajar.

Em (O1), a professora em formação Kelly sugeriu ao aluno que removessem as garrafas das sacolas com o fim de realizar perguntas, como observa-se em (O2), onde tenta que sejam os alunos que construa seu conhecimento e/ou lembre-lo tal como se apresenta em (O3), (O4); posteriormente, em (O5) o aluno através os exemplos, conceitua o conceito de resíduos sólidos, convidando-os desde modo a trabalhar (O6). A professora em formação Nelcy implementa esta estratégia de ensino, de forma análoga.

\subsection{CONJUNTO DE SITUAÇÕES 2: ESTRATÉGIAS CO-INSTRUCCIONAIS}

Neste conjunto de situações 2, localizamos as estratégias usadas pelas professoras em formação durante o desenvolvimento da tarefa; ou seja, quando os alunos estavam explorando a tarefa com o objetivo de resolver essa tarefa implementada pelas professoras em formação. Assim, a estratégia denominada "perguntas alternativas" foi implementada por ambas professoras em formação, e esta consistiu em fazer perguntas ao aluno para estimulara-lo tendo em conta seus conhecimentos prévios.

\section{Quadro 2. Estratégia de ensino "Perguntas alternadas"}

\author{
Momento da implementação \\ (O1) Nelcy: ¿Qué estas construyendo con ese molde? [molde de monedero] \\ (O2) Estudiante: Este molde es de una cartera. Pero, yo quiero hacer otra cosa \\ (O3) Kelly: ¿Qué quieres hacer? \\ (O4) Estudiante: Una billetera. Quiero aplastar las tapas y ver si me queda menos ordinario. \\ (O5) Kelly: Inténtalo. \\ (O6) Nelcy: Mira la piedra que tiene tu compañera pídesela y yo te ayudo a machacar las \\ tapas.
}

(O7) Estudiante: Listo.

As perguntas alternativas são feitas com as duas professoras em formação e um estudante quem tenta realizar um produto tecnológico, tal como observa-se em (O1) onde a professora em formação Kelly começa perguntando sobre o objeto a realizar e em (O2) o aluno responde-lhe o que ele deseja mais além do molde que deram-lhe, pelo que a professora em formação Kelly se integra no diálogo e pergunta-lhe que deseja fazer e encoraja-o a experimentá-lo como observa-se em (03), (O4) e (05); gerando em (06) que Nelsy visualize uma pedra, para apoiar o processo de construção do aluno e continue como mostra-se em (O7). 


\subsection{CONJUNTO DE SITUAÇÕES 3:} ESTRATÉGIAS POS-INSTRUCCIONAIS

Neste conjunto de situações 3, localizamos as estratégias utilizadas pelas professoras em formação depois da exploração da tarefa por parte dos alunos; ou seja, quando os alunos terminaram a realização da tarefa atribuída.
Neste conjunto de situações, localizamos a estratégia de ensino chamada "socialização da tarefa", que consistiu em convidar o aluno a compartilhar o desenvolvimento das tarefas atribuídas, mostrando como produto final os diferentes produtos tecnológicos. Um dos momentos referente à implementação desta estratégia de ensino mostra-se a continuação.

\section{Quadro 3. Estratégia de ensino "Socialização de tarefas"}

\section{Momento da implementação}

(O1) Nelcy: Es importante hacer un recuento para que nos quede claro y aprendan que la tecnología es todo lo que nos rodea; por ejemplo: En nuestra comunidad podemos ver muchos inventos que han sido producto de la tecnología. No sé si recuerdan que antes en las noches para alumbrarnos era con lámparas o velas y ya desde un tiempo hacia acá empezó la energía a través del fluido eléctrico, ahora ya está la interconexión. Entonces todos esos son productos tecnológicos pues todos tienen una gran connotación histórica.

(O2) Kelly: Entonces de acuerdo a lo que dijo mi compañera ahora ustedes digan cuáles son esas necesidades y experiencias en cuanto al medio ambiente y productos tecnológicos.

(O3) Estudiante: Yo tuve una experiencia que nunca había tenido; esas botellas que tomábamos gaseosas siempre las tirábamos al piso porque no teníamos conocimiento de que eso tenía otra utilidad, pero ahora nos han enseñado a usarlas y a hacer cosas nuevas con estas.

(O4) Estudiante: Aprendimos cosas ya que las profesoras nos enseñaron a hacer nuevas cosas con las botellas plásticas; jugamos, hicimos actividades sobre el medio ambiente, como cuidarlo. También nos colocaron muchos videos, donde lo que miramos lo pusimos en práctica.

(O5) Estudiante: ¡Profesoras! Yo construí un camión mírenlo. [Muestra el camión en movimiento]. Y ayude a construir la canoa que fue imuy bacana!

(O6) Nelsy: Muy bien, ese producto tecnológico hace parte de nuestras vidas.

Em (O1) podemos observar que a professora Nelcy socializa diferentes aspectos da tecnologia; em (O2), a professora Kelly convida os alunos a que socializem suas experiências e necessidades em torno do meio ambiente e produtos tecnológicos. Finalmente, em (O3), (O4), (O5), os alunos começam a contar as experiências adquiridas durante o desenvolvimento dos diferentes produtos tecnológicos; servindo de grande ajuda para o processo de construção dos mesmos.

Portanto, nesta seção apresentamos as estratégias utilizadas pelas professoras em formação, que foram apresentadas através de três conjuntos de situações mostram-se a descrição e classificação das mesmas tendo em conta a categorização abordada por Díaz \& Hernández (2010). No entanto, é importante notar que os nomes das estratégias de ensino "Perguntas Alternativas" e "Socialização da tarefa" foram tomados dos estudos realizados por Villota (2016).

$\mathrm{Na}$ seguinte tabela apresentamos de maneira sistematizada as estratégias de ensino utilizadas pelas professoras em formação para a elaboração de produtos tecnológicos mediante a utilização de garrafas plásticas e tampas, sua respetiva descrição e categorização. 
Quadro 4: Sistematização das estratégias de ensino implementadas por professoras em formação para a elaboração de produtos tecnológicos mediante a utilização de garrafas e tampas plásticas

\begin{tabular}{|l|l|l|}
\hline Estratégia de ensino & \multicolumn{3}{|c|}{ Descrição } \\
$\begin{array}{l}\text { Exploração } \\
\text { conceitos }\end{array}$ & $\begin{array}{l}\text { Consistiu em abordar diferentes } \\
\text { conceitos, por exemplo, médio ambiente, } \\
\text { ponto ecológico entre outros, com a fimação segundo } \\
\text { de ativar os conhecimentos prévios do } \\
\text { estudante. }\end{array}$ & Pre- instrucionais \\
\hline Perguntas alternadas & $\begin{array}{l}\text { Consistiu em realizar perguntas ao } \\
\text { estudante com o propósito de estimulara- } \\
\text { lo tendo em conta seus conhecimentos } \\
\text { prévios. Co- instrucionais }\end{array}$ & . \\
\hline Socialização da tarefa & $\begin{array}{l}\text { Consistiu em convidar ao estudante a } \\
\text { compartilhar o desenvolvimento das } \\
\text { tarefas correspondentes mostrando } \\
\text { como produto final os diferentes produtos } \\
\text { tecnológicos. }\end{array}$ & Pós-instrucionais \\
\hline
\end{tabular}

\section{DISCUSÃO DOS DADOS}

É importante lembrar que o objetivo deste estudo é descrever as estratégias implementadas pelas professoras em formação para o desenvolvimento de produtos tecnológicos mediante a utilização de garrafas e tampas de plástico. Para atingir este objetivo inicialmente, identificamos as estratégias implementadas pelas professoras em formação para o desenvolvimento de produtos tecnológicos através do uso de garrafas e tampas de plástico; para seguidamente descrever essas estratégias de ensino; e depois classificara-las tendo em conta a categorização proposta por Díaz \& Hernández (2010).

$\mathrm{Na}$ anterior seção, apresentamos as estratégias de ensino enquanto os três conjuntos de situação, onde localizamos as estratégias Pre-instrucionais, Coinstruccionais e Pós-instruccionais, as quais foram utilizadas pelas dois professoras em formação. Isto é nas Pre- instrucionais, localizamos a estratégia denominada "Exploração de conceitos"; nas Coinstruccionais temos a estratégia de ensino "Preguntas alternadas" e finalmente nas Posinstruccionais está localizada a estratégia de ensino "Socialização da tarefa".

A estratégia de ensino denominada "Exploração de conceitos", está localizada no conjunto de situações 1 , que tem como propósito fortalecer a apertura da tarefa, tentando informar, motivar e particularmente orientar ao estudante para desenvolver a mesma. Desta forma, as definições tiveram como intenção fazer uma curta introdução em relação a temática abordada com o estudante e reconhecer que eles tem conceitos prévios, os quais foram utilizados para a exploração das tarefas atribuídas aos estudantes. Consequentemente, Pérez \& Daza (2012) reconhecem que a conceptualização dos diferentes conceitos particularmente no meio ambiente e ciências naturais ajudam na aplicação da prática das ideias com as respostas às questões planteadas ao estudante no meio da tarefa; isto é, estabelecendo a relação entre pratica e teoria, organizando os conceitos de forma concreta.

Por outro lado, a estratégia denominada "Preguntas alternadas" que está localizada no conjunto de situações 2, teve intencionalidade de promover a procura de soluções às diferentes situações de ensino propostas pelas professoras em formação. É importante reconhecer que ao interior da implementação desta estratégia foi vital, evidenciar os conceitos prévios que o estudante tem para dar resposta aos diferentes problemas propostos pelas professoras em formação. Esta estratégia de ensino é abordada nos estudos de (Villota, 2016; Villota, Oliveira \& González, 2017), onde sua intencionalidade é 
promover os conhecimentos prévios dos estudantes, já que a forma de questionar pode fortalecer o processo de exploração da tarefa.

É importante salientar que no meio desta estratégia denominada questões alternadas, se implementaram diferentes vídeos referentes à temática do reciclagem, pois reconhecemos que a tecnologia faz parte da formação do professor conforme o argumenta, González (2015, p. 54):

Las barreras de los profesores para integrar la tecnología en sus estrategias de enseñanza es uno de los principales obstáculos a eliminar. Hay muchas cosas simples para comenzar; los profesores deben de estar conscientes de que el uso de la tecnología puede ampliar su campo de acción significativamente.

No conjunto de situações 3 temos a estratégia de ensino chamada "socialização da tarefa", a qual teve como intencionalidade que os estudantes compartilharam o desenvolvimento das diferentes tarefas propostas pelas professoras em formação, gerando em eles claridade, estimulação referente a suas dúvidas e poder assim ser respondidas. Nesta estratégia de ensino, os estudantes apresentaram a elaboração de seus produtos tecnológicos como por exemplo a canoa, carros em movimento, carteiras, entre outros. Consequentemente Villota, Oliveira \& González (2017, p. 76) abordam esta estratégia de ensino onde afirmam que:

[...]we have the teaching strategy called "socialization of the task", which is closely related to situation 11 where the teaching strategy called "clearing doubts" was addressed. In these two situations, the intentions of each teacher were to share one of the solutions of the task so that the student visualizes a way to solve the proposed task; stimulating their curiosities to supply their concerns $[\ldots]$.

A continuação apresentaremos as conclusões finais deste estudo, onde se tem em conta cada uma das estratégias implementadas pelas professoras na formação para a elaboração de produtos tecnológicos mediante a utilização de garrafas e tampas plásticas.

\section{CONCLUSÕES}

Este estudo nos conduz a reconhecer que as professoras na formação, implementaram diferentes estratégias para a elaboração de produtos tecnológicos mediante a utilização de garrafas e tampas plásticas, onde nosso foco foi a caracterização das mesmas utilizando distintas tarefas com a finalidade de que o estudante possa construir um produto tecnológico através dos resíduos sólidos, particularmente tampas e garrafas. Em consequência, as estratégias de ensino implementadas para a elaboração de produtos tecnológicos mediante a utilização de garrafas e tampas plásticas, foram descritas e classificadas tendo em conta a categorização tratada por Díaz e Hernández (2010), como Pre-instruccionais, Coinstruccionais e Pos-instruccionais, com a finalidade de estruturá-las e dar-lhes um determinado ordem no momento de ser utilizadas e apresentadas pelas professoras em formação no processo da implementação da tarefa.

Desta forma, a categorização nos ajudo a olhar o momento de implementação de determinada estratégia de ensino, onde sem dúvida cada uma de elas teve uma intencionalidade por parte das professoras na formação, girando ao redor do processo vinculado com a construção dos produtos tecnológicos. Não obstante, como descreve Villota (2016, p. 74), não todas as estratégias tem que enquadrar-se neste marco de classificação:

Es importante resaltar que puede acontecer que, algunas estrategias de enseñanza categorizadas dentro del conjunto de estrategias preinstruccionales, pueden también pertenecer al conjunto de estrategias coinstruccionales y/o al mismo tiempo posinstruccionales; por ejemplo, enunciar el objetivo de la tarea, o realizar la lectura compartida de la tarea; son estrategias que el profesor (a) podría usarlas durante o después de desenvolvimiento de la tarea. Análogamente, acontecería lo mismo con las co-instruccionales y preinstruccionales.

Assim, as estratégias de ensino tem que ser implementadas com rigor e muito cuidado já que estas podem ajudar no processo de ensino e aprendizagem ou pelo contrário impedi-lo, provocando grandes impactos no 
processo de aprendizagem do estudante. Assim, mais lá da implementação das estratégias de ensino, o professor tem que estar comprometido com o processo de investigação onde este the permita olhar, avaliar e assumir uma posição responsável sobre dita utilização de estratégias; pois se o professor não aceita dita responsabilidade, pode fazer que as estratégias sejam um receituário que pode ou não funcionar dependendo de diferentes variáveis como: o contexto, os recursos entre outros.

Por outro lado, referente à recolecção dos resíduos sólidos como as tampas e garrafas se conseguiu olhar que embora as personas

\section{AGRADECIMENTOS}

Agradecemos às professoras em formação Kelly Viviana Rincón Hurtado e Nelcy Yesury Portocarrero Ortiz, atualmente estudantes da faculdade de educação da USC, por permitirnos acompanhá-las neste processo de investigação, que sem dúvida deixo rastro na comunidade de Telembi. Ademais estendemos nossos agradecimentos à comunidade de Telembi por permitir realizar

\section{REFERÊNCIAS}

ACOSTA, Savier; GARCÍA María. Estrategias de enseñanza utilizadas por los docentes de biología en las universidades públicas. Omina, 18,67-82. Maracaibo Venezuela. 2012

ANIJOVICH, Rebeca.; MORA Silvia. Estrategias de enseñanza: Otra mirada al quehacer en el aula. Buenos Aires (Argentina): AIQUE, 2009.

CASTELLS, Manuel. A revolução da tecnologia da informação. In: A sociedade em rede. 17. ed. rev. ampl. São Paulo: Paz e Terra, 2016, p.87-133.

CRESWELL, J. W. Projeto de pesquisa: métodos qualitativo, quantitativo e misto. Tradução Luciana de Oliveira da Rocha. 2. ed. Porto Alegre: Artmed, 2007

DÍAZ, Frida.Barriga; HERNÁNDEZ Gerardo Rojas. Estratetegias docentes para un aprendizaje significativo, McGRAW-HILL/INTERAMERICANA EDITORES, S.A.DE C.V., ISBN: 978-607-15-02933, Tercera edición, México, 2010.

FRANTZ, Telmo Rudi. Inovação tecnológica, aprendizagem e competitividade: um olhar sobre a experiência brasileira. Cadernos Unijuí - Série Ciências Sociais, nº 23. ljuí: Ed. Unijuí, 2002. 88 p.

GONZALEZ, Heriberto Valencia; VILLOTA, Jakeline Enríquez; AGREDO, Patricia Medina. Strategies da comunidade estão na luta de aprender a utilizar estes com o propósito de gerar novos elementos y/o produtos tecnológicos que the facilitem várias das atividades que fazem parte de sua vida cotidiana, ficando como semente a motivação na comunidade para realizar sessões de trabalho onde cada pessoa interessada, fabrique seus produtos tecnológicos e assim possam ser comercializados com pessoas dentro y/o afora da comunidade. Assim, este estudo foi o ponto gerador de conscientização na reutilização de resíduos sólidos e conscientizar ao cuido do meio ambiente que hoje está submerso na contaminação que ao passo do tempo, se agudiza.

este processo de investigação em parceria com a Universidade Santiago de Cali, especialmente ao programa de Licenciatura em Educação Básica com ênfases em Tecnologia e Informática, Licenciatura em Educação Básica com ênfases em Ciências Naturais adscritos à Faculdade de Educação. Nossos gratos agradecimentos ao $\mathrm{Mg}$. Mardochée Ogécime por nossos debates sobre esta temática ¡Imensamente agradecidas!

Used by Professors through Virtual Educational Platforms in Face-To-Face Classes: A View from the Chamilo Platform. English Language Teaching; Vol. 10, No. 8. pp. 1-10. ISSN 1916-4750. Doi 10.5539/elt.v10n8p1. 2017. Acesso: URL: http://doi.org/10.5539/elt.v10n8p1

GONZÁLEZ, Heriberto Valencia. La integración de la tecnología como herramienta significativa en la enseñanza del inglés como lengua extranjera. Revista Horizontes Pedagógicos. 17(1), 53-66. 2015.

INFO.BRUXELAS. Viver bem, dentro dos limites do nosso planeta. Sexta-feira, 26 de junho de 2015 , p.2.

KOHLER, Johana. Importancia de las Estrategias de Enseñanza y el Plan Curricular. Liberabit Revista de Psicología, v. 11, n. 11, p. 25-34, 2005. Disponível em: . Acesso em: 18 Outubro de 2014. Em: VILLOTA, Jakeline Enríquez; VILLOTA, Maribel Enríquez; OGÉCIME, Mardochée. Estrategias de enseñanza utilizadas en el desenvolvimento de tareas matemáticas: Importancia en su utilidad. Revista SIGMA, 12(2), 53-70. 2017.

ALCALDIA DE POLICARPA. (s.f.). Manual de la Alcaldia de Policarpa. Consultado en 2017. 
MUSSET, Marie.: L'éducation au développement durable. Dossier d'actualité de la VST. Vol.56 (2010).

PÉREZ, S. E \& DAZA, E. P. Estilos de aprendizaje; una contextualización didáctica para direccionar el modelo pedagógico de las instituciones educativas. Memorias del congreso I Congreso Latinoamericano de Investigación en Didáctica de las Ciencias Experimentales. 2012.

PERPIGNAN, Catherine; ROBIN, Vincent; GIRARD, Philipe. Vers une éducation intégrée du développement durable dans l'enseignement technologique dès le secondaire. CONFERE'16. Prague, 2016.

PNUD. Objectivos de Desarrollo Sostenible, Cplombia. Herramientas de aproximación al contexto local. Colombia, 2015.

RESTREPO, B. Una Variante Pedagógica de la Investigación Acción Educativa. OEl-Revista Iberoamericana de Educación. 2005. Disponible: http://www.rieoei.org/ de los lectores/370Restrepo.PDF. Em: LEWIN et al. La investigación-acción y los problemas de las minorías. En: Salazar, M.C. (Comp) (1992). La Investigación acción Participativa. Inicios y Desarrollos. (p. 13 -25) Colombia: Editorial Popular. OEI, Quinto Centenario.1946.

SANTAMBROSIO, Eduardo. Tecnología y medio ambiente. Colección de Cueadernillos UCEL. Universidad del Centro Educativo Latinoamericano. Rosario. Argentina. 2001.

UNESCO. Educação para a cidadania global: Preparando alunos para os desafios do século XXI. Brasília, 2015. 44p.

UNESCO. La Educación para el Desarrollo Sostenible en acción. Sector Educación de la UNESCO. Instrumentos de aprendizaje y formación N 4. Paris, 2012.

VILLAMIL, Hernán Rodriguez; GUERRA M. Yolanda. Propuesta de Educación para el desarrollo sostenible: Perspectiva pedagógica para la Universidad Militar Nueva Granad. Revista Educación y desarrollo social. Vol. 3 No. 2. Colombia, 2009.

VILLOTA, Jakeline Enríquez. Estratégias utilizadas por professores que ensinam matemáticas na implementação de tarefas. Dissertação de Mestrado. Programa de Pós-graduação de Ensino, Filosofia e História das Ciências. Universidade Federal da Bahia. Salvador da Bahia. Brasil. 2016.

VILLOTA, Jakeline Enríquez; RIASCOS, Yilto, Forero. Estrategias utilizadas por profesores para fortalecer la seguridad de la información en una plataforma virtual: El caso de la plataforma educativa Chamilo. Memorias de la Asociación Red Universitaria de Alta Velocidad del Valle del Cauca (RUAV). Universidad Cooperativa de Colombia, Cali. 2017.

VILLOTA, Jakeline Enríquez et al. Estrategias utilizadas por profesoras en formación para la elaboración de productos tecnológicos mediante implementación de residuos sólidos. Congresso Internacional de Educação a distância. DOI: 10.17143/ciaed/XXIIICIAED.2017.00123. Memorias do Congresso Internacional de Educação a Distância. Foz de Iguaçu, Brasil. 2017.

VILLOTA, Jakeline Enríquez; VILLOTA, Maribel Enríquez; OGÉCIME, Mardochée. Estrategias de enseñanza utilizadas en el desenvolvimento de tareas matemáticas: Importancia en su utilidad. Revista SIGMA, 12(2), 53-70. 2017. Recuperado de http://revistas.udenar.edu.co/index.php/rsigma/ article/view/3169

VILLOTA, Jakeline Enríquez; OLIVEIRA, Andreía Pereira; GONZÁLEZ, Heriberto Valencia. What Mathematic Teachers Say about the Teaching Strategies in the Implementation of Tasks. English Language Teaching; Vol. 11, No. 1. pp. 1-10. Canada. 2018. 


\section{Capítulo 15}

\section{METODOLOGIAS ATIVAS: TECNOLOGIAS COM UM NOVO OLHAR PARA A INCLUSÃO}

ASSISTIVAS

Rita de Cássia Borges de Magalhães Amaral

Nacyra Yiburi Fernandes de Lucena

Fernanda Beatriz Pereira de Abreu

Juçara Pereira Barbosa

Rejane Araújo da Silva

Resumo: O presente artigo visa mostrar a utilização das tecnologias assistivas nas metodologias ativas e na adaptação curricular. Para tanto, vamos apresentar como as metodologias ativas podem contribuir para uma formação significativa pelo aluno nos seus saberes e necessidades, utilizando como um dos instrumentos as tecnologias assistivas e apontando as adaptações no currículo necessárias para resolver as demandas apresentadas nas instituições de ensino. Para averiguar as diversas tecnologias assistivas Começaremos por entendê-las e saber de que forma elas funcionam, com a finalidade de aumentar habilidades funcionais, assim proporcionando uma maior independência para estas pessoas. A pesquisa de campo conclui o devido artigo e a partir dela e dos estudos realizados foram feitas algumas sugestões para serem aplicadas e entender a adaptação curricular acerca de suprir as dificuldades de aprendizagem escolar, desde situações mais leves e transitória, até situações mais graves e persistentes requerendo uso de recursos especiais, para atuar frente às dificuldades de aprendizagem dos alunos quando necessário, para torná-lo apropriado às suas peculiaridades.

Palavras-chave: Metodologia ativa, tecnologia assistiva e adaptação curricular. 


\section{INTRODUÇÃO}

Neste artigo é tratado o emprego das tecnologias assistivas nas metodologias ativas e na adaptação curricular. As metodologias ativas têm como objetivo promover no aluno uma concepção mais reflexiva e crítica em que as suas habilidades e competências estarão sendo desenvolvidas para que este encontre soluções adequadas para os problemas vivenciados na sua formação. Mas também propor ao professor uma reflexão sobre a sua prática em sala de aula e uma reformulação dos métodos utilizados para atender as especificidades dos alunos acompanhando as mudanças sócio-políticas, financeiras e tecnológicas na sociedade moderna.

A Lei 13.146/16 - Lei Brasileira de Inclusão da Pessoa com Deficiência (Estatuto da Pessoa com Deficiência), é destinada a assegurar e a promover, em condições de igualdade, o exercício dos direitos e das liberdades fundamentais por pessoa com deficiência.

Tecnologia Assistiva é um novo conceito que contribui para proporcionar, ampliar e facilitar algumas habilidades funcionais de pessoas com deficiência e logo promover maior independência e Inclusão, principalmente a comunicação alternativa.

A adaptação curricular envolve modificações organizativas tanto nos objetivos, nos conteúdos, nas metodologias quanto nas organizações da didática permitindo ao educando atendimento específicos.

Portanto, o objetivo geral desta pesquisa é utilizar das tecnologias assistivas nas metodologias ativas e na adaptação curricular. E para melhor desenvolvimento do estudo foram elencados como objetivos específicos: compreender as metodologias ativas; averiguar as tecnologias assistivas e entender a adaptação curricular.

Esta pesquisa se justifica por ter sido observado que algumas escolas incluem os alunos por força da lei e desta forma o aluno fica excluído e assim sendo através da metodologia ativa utilizando as tecnologias assistivas esta situação seria revertida.

Com esta pesquisa pretende-se que tanto as escolas e como os profissionais de educação tenham a oportunidade de apropriar-se de um ambiente de aprendizagem mais adequado aos alunos com necessidades educativas especiais, sejam elas físicas, cognitivas, intelectuais, afetivas ou sociais.

A relevância do artigo se faz tanto para a comunidade escolar, o sistema de ensino, os educadores quanto para os alunos com necessidades educativas especiais, pois mostra maneiras de remover os conflitos que impedem e dificultam no processo ensino aprendizagem e na participação dos alunos na escola e na vida social.

O projeto pedagógico da escola inclusiva deve conter um currículo que garanta a participação dos educandos com necessidades especiais nas suas especificidades. As adaptações curriculares, então, são os ajustes e modificações que devem ser promovidos nas diferentes instâncias curriculares, para responder às necessidades de cada aluno, assim favorece as condições que the são necessárias para que se efetive o máximo possível de aprendizagem (ARANHA, 2003, p.10).

Para realizar adaptação curricular é necessário que o projeto pedagógico da escola e o planejamento de ensino considerem objetivos educacionais e estratégias didáticas pedagógicas (SASSAKI, 2003, p.10).

De acordo com os Parâmetros Curriculares Nacionais adaptações curriculares - PCNs (1998), qualquer adaptação curricular deve ser construída considerando os seguintes critérios: O que o aluno deve aprender; como e quando aprender; que formas de organização do ensino são mais eficientes para o processo de aprendizagem e como e quando avaliar o aluno.

\section{METODOLOGIAS ATIVAS}

As metodologias ativas (MA) apresentam-se como um instrumento para a construção do conhecimento usando procedimentos analíticos e dialógicos. É uma concepção educativa que estimula processos de ensinoaprendizagem crítico-reflexivos, no qual o educando participa e se compromete com seu aprendizado.

As MA propõem uma educação centrada no aluno, em que este é orientado por um professor que irá proporcionar experiências estimuladoras que o levarão a buscar recursos interiores para interagir com as situações desafiadoras do cotidiano. 
Portanto segundo essa abordagem as informações só serão absorvidas pelos alunos se tiverem um significado. Assim realizarão uma conexão com as suas experiências, sofrendo a influência do meio onde estes estão inseridos e promovendo mudanças nas suas percepções sobre o mundo.

Nas bases teóricas destas metodologias podemos identificar princípios análogos defendidos por Dewey e Freire nas décadas precedentes. Dewey formulou um ideal pedagógico (da Escola Nova) onde a aprendizagem acontecia pela ação, o aprender fazendo. Preconizava a iniciativa, a originalidade e cooperação que promoveria as potencialidades dos indivíduos na construção de uma ordem social aprimorada. E explicava que as experiências concretas da vida se apresentavam diante de problemas que mobilizavam 0 ato de pensar, possibilitando estágios de reflexão, elaboração de soluções e ações para a resolução.

Paulo Freire incentivava o desenvolvimento de uma Pedagogia problematizadora em que "educador e educando aprendem juntos, numa relação dinâmica na qual a prática, orientada pela teoria, reorienta essa teoria, num processo de constante aperfeiçoamento" (GADOTTI,2006,p.253) Nesta práxis o conhecimento utilizado seria o da realidade do educando, em que neste seria desenvolvida uma conscientização para a sua autonomia.

A implantação das metodologias ativas requer uma análise do currículo que se pretende trabalhar para a formação do aluno enfatizando tanto os conhecimentos específicos como a colaboração, interdisciplinaridade, habilidade para inovação, trabalho em grupo e educação para o desenvolvimento sustentável, regional e globalizado.

Por isso a clareza e objetividade do Projeto Político Pedagógico (PPP) instituído pelo estabelecimento de ensino será fundamental para a escolha das metodologias ativas a serem utilizadas no trabalho educacional. É necessário um mapeamento da clientela que será atendida para buscar professores com formação adequadas ao perfil traçado pela instituição.

A metodologia de ensino que tem como meta a combinação e concretização dos seguintes aspectos: relações entre professores e alunos, o ensino-aprendizagem, objetivos de ensino, finalidades educativas, conteúdos cognitivos, métodos e técnicas de ensino, tecnologias educativas, avaliação, faixa etária do educando, nível de escolaridade, conhecimentos que o aluno possui, sua realidade sociocultural, projeto políticopedagógico da escola, sua pertença a grupos e classes sociais, além de outras dimensões societárias em que se sustenta uma dada sociedade.

Seguiremos reiterando a proposta das metodologias ativas com uma maior participação do aluno, a liberdade de escolha e contextualização do conhecimento; estimulando atividades em grupo e usando diversos recursos para a socialização do conhecimento. Entre as metodologias podese destacar: A aprendizagem baseada em problemas inicia a aprendizagem criando a necessidade de resolver um problema não estruturado. Durante o processo, os alunos constroem o conhecimento do conteúdo e desenvolvem habilidades de resolução de problemas, bem como as competências de aprendizagem auto-dirigida.

A aprendizagem baseada em projetos tem sido caracterizada como um processo dinâmico, participativo e interdisciplinar centrado na aprendizagem do aluno. Tendo como procedimento primordial a conscientização do discente sobre o que ele necessita aprender e a motivação pela busca de informações relevantes. Promove o estímulo à aprendizagem, trabalho em equipe, a escuta do outro e a responsabilidade por suas atitudes.

$\mathrm{Na}$ metodologia da sala de aula invertida os assuntos e as indicações são direcionados aos alunos antes dele ir para sala de aula através de materiais on-line. O aluno estuda os conteúdos antes da aula, que se torna o lugar de aprendizagem ativa, onde há perguntas, discussões e atividades práticas. o foco é o aluno que terá as suas dificuldades trabalhadas, ao invés de apresentações sobre o conteúdo das disciplinas pelo professor.

O estudo do caso é uma metodologia onde um caso será discutido pelos alunos que desenvolverão habilidades no processo de argumentação, pois lidarão com informações ou perguntas inesperadas, assim como na experimentação de ideias e soluções. É um desafio para o professor que tem de dominar fatos, questões, cálculos e outros materiais do caso em questão. O Peer instruction é focado no aluno como construtor do seu 
conhecimento juntamente com outros alunos. Serão formuladas questões destinadas a envolver os alunos e descobrir dificuldades com o material. Oferece um ambiente estruturado para os alunos exporem suas ideias e solucionar mal-entendido, conversando com seus pares. Tem como característica um ambiente cooperativo onde todos trabalham em conjunto para aprender novos conceitos e habilidades.

O Blended learnig pode ser definido como um programa de educação formal que mescla os momentos em que o aluno estuda os conteúdos e instruções usando recursos online, e outros em que o ensino ocorre em sala de aula, podendo interagir com outros alunos e com o professor. O material usado é elaborado especificamente para a disciplina. Neste método a parte presencial será supervisionada pelo professor que irá valorizar as interações e complementar as atividades on-line, favorecendo um processo de construção do conhecimento eficiente.

A educação à distância tem como ponto principal uma relação de aprendizagem em que professor e aluno estão separados fisicamente no espaço el ou no tempo utilizando como recursos as tecnologias de informação e comunicação podendo ou não apresentar momentos presenciais. Isso contribui para o acesso a aqueles que vêm sendo excluídos do processo educacional por morarem em locais de difícil acesso, tendo uma relevância social fundamental que contribuirá para o desenvolvimento econômico.

As tecnologias educacionais são um conjunto de ferramentas didáticas utilizadas no processo de ensino aprendizagem que permitem aplicabilidades pedagógicas inovadoras, contribuindo para a democratização do ensino. Mas professor necessita de qualificação para manejar essas tecnologias, pois pode utilizar desde a pesquisa em sites a plataformas educacionais.

\section{TECNOLOGIAS ASSISTIVAS}

De acordo com a definição proposta pelo Comitê de Ajudas Técnicas (CAT), tecnologia assistiva "é uma área do conhecimento", de característica interdisciplinar, que engloba produtos, recursos, metodologias, estratégias, práticas e serviços que objetivam promover a funcionalidade, relacionada à atividade e participação, de pessoas com deficiência, incapacidades ou mobilidade reduzida, visando sua autonomia, independência, qualidade de vida e inclusão social (BRASIL, 2009).

"Para as pessoas sem deficiência a tecnologia torna as coisas mais fáceis. Para as pessoas com deficiência, a tecnologia torna as coisas possíveis" (RADABAUGH, 1993).

Com a chegada das tecnologias assistivas, o educador deixa de ser o detentor do saber, para ser um transformador de conquistas, um mediador. Em algumas escolas podemos presenciar mudanças, tanto nos profissionais, quanto na estrutura escolar, os Atendimento Educacional Especializado (AEE ) com as Salas de recursos multifuncionais (SRMF).

Segundo o site Assistiva (2014) as salas de recursos são espaços físicos localizados nas escolas públicas onde se realiza o Atendimento Educacional Especializado AEE. As SRMF possuem mobiliário, materiais didáticos e pedagógicos, recursos de acessibilidade e equipamentos específicos para o atendimento dos alunos que são público alvo da Educação Especial e que necessitam do AEE no contra turno escolar.

\section{ADAPTAÇÃO CURRICULAR}

Adaptação Curricular é a resposta educativa dada pelo sistema educacional, que favorece a todos os alunos principalmente os que apresentam algumas peculiaridades e necessidades especiais, ou seja, é conjunto de modificações para o atendimento ao aluno, tornando uma relação harmoniosa entre as atividades e o currículo exigindo uma reflexão sobre o que é o currículo: O que aprender? Quando e como aprender? Que formas de organização do ensino são mais eficientes para o processo de aprendizagem? Como e quando avaliar o aluno?

De acordo com a LDB 9394/96 no art. 59. Os sistemas de ensino assegurarão aos educandos [...]:currículos, métodos, técnicas, recursos educativos e organização específicos, para atender às suas necessidades. Segundo com Glat (2002, p.3) adaptações curriculares "são ajustes realizados no currículo para que ele se torne apropriado ao acolhimento das diversidades do alunado - currículo verdadeiramente inclusivo; currículo dinâmico". 
Franco fala que (2007, p.7) "As adaptações curriculares, de planejamento, objetivos, atividades e formas de avaliação, no currículo como um todo, ou em aspectos dele, são para acomodar os alunos com necessidades especiais".A mesma autora ratifica que as adaptações curriculares são o caminho para o atendimento as necessidades específicas de aprendizagem. Identificar essas "necessidades" requer que os sistemas educacionais modifiquem não apenas suas atitudes e expectativas em relação a esses alunos, mas que se organizem para construir uma escola para todos.

O trabalho do professor da sala de aula e dos professores de apoio precisam ser realizados de forma cooperativa, interativa e bem definida, a organização do espaço e dos aspectos físicos da sala de aula, a boa utilização e a otimização desses recursos e a utilização dos recursos materiais, equipamentos e mobiliários de modo que favoreça a aprendizagem de todos os alunos.

As adaptações de acesso ao currículo formaram um conjunto de modificações tanto nos elementos físicos, nos materiais do ensino, como nos recursos pessoais do professor quanto ao seu preparo para trabalhar com os alunos.

Segundo Aranha (2003) as medidas que constituem adaptações de acesso ao currículo são: · criar condições físicas e ambientais para os alunos propiciando melhores níveis de comunicação e interação com as pessoas com as quais convivem na comunidade escolar, favorecer a participações em todas as atividades escolares, · propiciar o mobiliário específicos para cada peculiaridade, fornecer quipamentos e recursos materiais específicos, adaptar material de uso comum em sala de aula, adotar sistemas de comunicação alternativos para os alunos que são impedidos de comunicação oral.

\section{PROCEDIMENTOS METODOLÓGICOS}

Como característica do estudo, a metodologia utilizada nesse artigo foi a realização de uma análise exploratória, de natureza qualitativa. Realizou-se ainda uma pesquisa de campo com alunos de graduação em Pedagogia e alunos da Pós graduação na área da educação das Faculdades São José. Quanto às discussões sobre as metodologias ativas o estudo ocorreu por meio de pesquisas bibliográficas como artigos, leituras, bibliografias específicas

\section{DISCUSSÃO DOS RESULTADOS}

A pesquisa de Campo foi realizada com 5 (cinco) alunos do curso de graduação em Pedagogia e 5 (cinco) alunos da Pósgraduação na área da educação das Faculdades São José. A nossa pesquisa era composta de 6 perguntas.

Na primeira pergunta buscou-se saber se os pesquisados sabiam o que era metodologia ativas e no grupo da graduação 3 responderam que sim e 2 responderam que não. No grupo de pós graduação todos responderam que sim. Estes resultados mostram que quando os estudos se aprofundam a consequência é um maior conhecimento.

$\mathrm{Na}$ segunda pergunta foi perguntado se lembra de alguma aula com metodologias ativas e as respostas na graduação foram 3 sim, na aula de metodologia de Ciências na observação da Lua e na montagem da Feira de Ciências onde a interação aconteceu pelo Facebook e 2 não; na pós todos responderam que sim e que esta metodologia foi vivenciada através dos debates e apresentações de trabalho.

$\mathrm{Na}$ terceira pergunta foi perguntado "O que entende por tecnologia assistiva" e o resultado foi na graduação foi que se refere a meios para ajudar as pessoas com diversidade funcional e na pós foi que são tecnologias elaboradas para facilitar a aprendizagem e a vida de pessoas com diversidade. $\mathrm{Na}$ quarta pergunta foi perguntado você conhece a lei Brasileira da Inclusão e o resultado na graduação e na pós foram iguais, 2 sim e 3 não o que nos indica que esta nova lei precisa ser mais estudada nos diferentes cursos. Na quinta pergunta foi perguntado se as adaptações curriculares auxiliam as dificuldades de aprendizagem dos alunos e o resultado foi sim em ambos os cursos e as justificativas ficaram em torno de que permitem a flexibilidade no processo ensino aprendizagem.

E finalmente na sexta questão foi perguntado se você considera a adaptação curricular como um processo dinâmico e flexível e o resultado foi idêntico na graduação e na pós, onde tivemos $4 \operatorname{sim}$ e 1 não. As respostas sim se justificam por ser um processo que auxilia nas diferentes diversidades dos alunos e as 
respostas não dizem que os professores e equipe escolar como um todo não estão preparados para realizar adaptação curricular.

Esta pesquisa mostra que as metodologias ativas, as tecnologias assistivas e as adaptações curriculares, são temas que já fazem parte da área educacional, mas é preciso que sejam mais estudados a fim de que todos possam se utilizar deles no processo ensino aprendizagem

\section{CONSIDERAÇÕES FINAIS}

Ficou entendido neste estudo que o conhecimento destes temas fará com que o processo ensino aprendizagem se desenvolva com uma melhor qualidade. O mesmo ficou evidenciado na pesquisa de campo. As metodologias ativas contribuem para um aprendizado completo, em que sujeitos ativos adquirem autonomia de pensar e agir tornando-se elementos transformadores dos sistemas educacionais.

\section{REFERÊNCIAS}

[1] ARANHA, M.S.F. Referenciais para construção de sistemas educacionais Inclusivos a fundamentação filosófica - a história - a formalização. Versão preliminar. Brasília: MEC/SEESP, nov. 2003.

[2] BRASIL. Ministério da Educação. Lei de Diretrizes e Bases da Educação Nacional. LDB 9.394, de 20 de dezembro de 1996.

BRASIL, Ministério da Educação e do Desporto, Secretaria de Educação Fundamental. Parâmetros Curriculares Nacionais adaptações curriculares Brasília: MEC/SEF, 1998b.

[3] BRASIL, Ministério da Educação. Diretrizes Nacionais para a Educação Especial MEN SEESP 2001 disponivel em: $<$ http://portal.mec.gov.br/seesp/arquivos/pdf/diretri zes.pdf> Acesso: em 10/11/2016.

[4] BRASIL. Subsecretaria Nacional de Promoção dos Direitos da Pessoa com Deficiência. B823 t Comitê de Ajudas Técnicas Tecnologia Assistiva. (CAT) - Brasília : CORDE, 2009. Disponível
As necessidades educativas especiais têm revelado quais são os tipos de ajudas que são requeridos, de modo a cumprir as finalidades da educação, visto isso, a organização do projeto político pedagógico da escola e o sistema escolar como um todo, introduz as adaptações necessárias para a inclusão e participação efetiva dos discentes com necessidades educativas especiais em todas as atividades escolares o conteúdo a ser ministrado e as formas que se ensinam e avaliam, são definidas como alterações realizadas nos critérios e procedimentos de avaliação e atividades para atender às diferenças de cada educando está inovação cada vez mais vem implicando mudanças de paradigmas educacionais gerando uma reorganização nas práticas escolares baseada no propósito de ensino especializado.

A Adaptação Curricular é a resposta educativa dada pelo sistema educacional, que favorece todos os alunos principalmente os que apresentam algumas peculiaridades e necessidades especiais.

<http://www.pessoacomdeficiencia.gov.br.> Acesso: 13/11/2016.

[5] BRASIL, Política Nacional de Educação Especial na Perspectiva da Educação Inclusiva, 2013. Disponível em: <http://portal.mec.gov.br> Acesso em: 18/11/2016.

[6] FRANCO, Valéria Korik. Adaptação Curricular (2007). Disponível em: <caminhosda inclusão.blogspot.com> Acesso em 22/10/16

[7] GADOTTI, Moacir. História das idéias pedagógicas. 8 ed. São Paulo: Cortez, 2006.

[8] GLAT, Rosana; OLIVEIRA, Eloiza da Silva Gomes de. Adaptação Curricular. 2002. Disponível em: <http://www.cnotinfor.pt/inclusiva/pdf> Acesso em: 23/10/16.

[9] SASSAKI, R. A educação inclusiva e os obstáculos a serem transpostos. entrevista concedida ao Jornal dos Professores, órgão do Centro do Professorado paulista, NO. 343, FEV, 2003. 
Alutary 


\section{ALDINEIA DO SOCORRO OLIVEIRA MAIA PEREIRA}

Possui graduação em Licenciatura Plena em Pedagogia pela Universidade Federal do Pará (2003) e mestrado em Serviço Social pela mesma universidade (2007). É professora da Secretaria de Estado de Educação SEDUC/Pa. Tem experiência na área de Educação Básica, atuando principalmente nos seguintes temas: políticas públicas e infância, inclusão, Estado, Políticas sociais, desenvolvimento infantil, exclusão escolar e formação de professores.

\section{ANA CRISTINA PIMENTEL CARNEIRO DE ALMEIDA}

Graduação em Educação Física (UFRRJ), Mestre em Educação Física (UFSC) e Doutora em Ciências (UFPA). Professora Associado II da Universidade Federal do Pará. Atua no Programa de Pós-Graduação em Educação em Ciências e Matemáticas e no Mestrado Profissional em Docência (IEMCI/UFPA). Vice-Líder do Grupo de Estudos em Ciência, Tecnologia, Sociedade e Ambiente e Líder do Laboratório de Ensino de Ludicidade (IEMCI/UFPA). Pesquisadora do Laboratório de Estudos do Lazer (UNESP/Rio Claro/SP). Áreas de atuação: Lazer, Educação Ambiental, Meio Ambiente e Formação Docente, Ludicidade no Ensino de Ciências, Relações entre Ciência, Sociedade e Cidadania.

\section{ANELISE GRÜNFELD DE LUCA}

Licenciada em Química/UNIJUÍ, Mestre Em Educação e Cultura/UDESC- SC e doutora em Educação em Ciências Química da Vida e Saúde/UFRGS. Atualmente é professora no Instituto Federal Catarinense - Campus Araquari/SC, atua na Licenciatura em Química, sendo que a área de pesquisa se concentra na experimentação no ensino, o uso de livros de divulgação cientifica no Ensino de Ciências e História da Ciência. Ministra as disciplinas de Estágio Supervisionado, Metodologia do Ensino de Química e Didática das Ciências.

\section{ÂNGELA COLETTO MORALES ESCOLANO}

Possui Graduação, Mestrado e Doutorado em Psicologia pela FFCLRP-USP. Atualmente é Professora Assistente Doutora da Universidade Estadual Paulista "Julio de Mesquita Filho", Campus de Ilha Solteira. Tem experiência na área de Psicologia, com ênfase em Psicologia do Ensino e da Aprendizagem e Psicologia do Desenvolvimento, atuando principalmente nos seguintes temas: Formação de Professores, Mediação da Aprendizagem, Avaliação Assistida, Desempenho Escolar. Coordenadora de Área do PIBID/Capes/UNESP para o Curso de Licenciatura em Ciências Biológicas da FE-UNESP-Campus de Ilha Solteira.

\section{ANTONIO HENRIQUE PINTO}

Prof. Dr. do Instituto Federal de Educação do Espírito Santo. Docente e pesquisador no campo da História da Educação Matemática e Educação Profissional, com foco na Formação de Professores, no Currículo e na Prática Pedagógicas. Possui doutorado em Educação (FEUnicamp), Mestrado em Educação (CE-UFES), Graduado em Licenciatura de Matemática. É Coordenador do Programa de Pós Graduação em Educação Profissional e Tecnológica (Ifes) e docente do Programa de Mestrado Profissional Educação em Ciências e Matemática (IFES). Coordenador de Grupo de Pesquisa Educação Básica e Educação Profissional (GEPEBE). Coordenador do Sub Projeto Projeto Pibid - Matemática de Iniciação à Docência. Trabalhos publicados sobre formação de professores, currículo e história da educação. 
Mestrado em Educação Para a Ciência e o Ensino de Matemática pela Universidade Estadual de Maringá, Brasil(2015). Professor Assistente da Universidade do Estado de Santa Catarina, Brasil.

\section{CARLOS EDUARDO PEREIRA AGUIAR}

Professor Formador do Projeto de Tutoria Educacional da SEMED-Manaus - Atual. Mestre em Ensino de Ciências e Matemática - 2017. Coordenador de Telecentros da SEMED-Manaus 2014-2017. Professor Tutor do Curso de Pós-Graduação Lato Sensu em Educação Ambiental da UFAM - 2014-2016. Professor Supervisor do Programa Institucional de Bolsas de Iniciação à Docência da UFAM - 2009-2010. Professor de Ciências e Química da SEDUC-AM, SEMEDManaus e Rede Privada - 2002-2013. Pós-Graduado (Lato Sensu) em Psicopedagogia pela UFRJ - 2001. Pós-Graduado (Lato Sensu) em Química pela UFLA - 2000. Graduado em Licenciatura em Ciências com Habilitação em Química pela UNISANTA - 1994.

\section{CARLOS EDUARDO ROCHA}

Graduando em Licenciatura em Química pela Universidade do Estado de Santa Catarina.

\section{DUAN CEOLA}

Graduando em Licenciatura em Química pela Universidade do Estado de Santa Catarina.

\section{EHRICK EDUARDO MARTINS MELZER}

Doutorando em Educação na Universidade Federal do Paraná na Linha de Políticas Educacionais. Possui graduação em Química: Licenciatura pela Universidade Federal do Paraná (2010) e mestrado em EDUCAÇÃO EM CIÊNCIAS E EM MATEMÁTICA pela Universidade Federal do Paraná (2012). Atualmente é professor assistente classe a da Universidade Federal do Paraná. Tem experiência na área de Educação, com ênfase em Educação do Campo, atuando principalmente nos seguintes temas: ensino de química, transposição didática, ensino de ciências, ead e didática das ciências.

\section{FABÍOLA SUCUPIRA FERREIRA SELL}

Doutorado em Linguística pela Universidade Federal de Santa Catarina, Brasil(2003) Professora da Universidade do Estado de Santa Catarina, Brasil

\section{FERNANDA BEATRIZ PEREIRA DE ABREU}

Graduanda em Pedagogia 


\section{FERNANDA DA ROCHA BRANDO}

Licenciada em Ciências Biológicas pela Universidade do Sagrado Coração (USC, 2000); especialização em Gestão Ambiental pela Universidade Federal de São Carlos (UFSCar, 2001), mestrado (UNESP, 2005) e doutorado em Educação para a Ciência pela Universidade Estadual Paulista Júlio de Mesquita Filho - Campus Bauru (UNESP, 2010). Atualmente é Professora Doutora do Departamento de Biologia da Faculdade de Filosofia, Ciências e Letras de Ribeirão Preto da Universidade de São Paulo (FFCLRP-USP), ministrando as disciplinas "Educação Ambiental" e "Metodologia científica da pesquisa em Ensino de Biologia e de Ciências" no curso de Ciências Biológicas. É credenciada no Programa de Pós-graduação em Biologia Comparada e no Programa de Pós-graduação em Rede Nacional Para o Ensino das Ciências Ambientais. Coordena o Laboratório de Epistemologia e Didática da Biologia (LEDiB). É pesquisadora colaboradora do Grupo de História e Teoria da Biologia (GHTB-USP) e do Grupo de Pesquisas em Epistemologia da Biologia (GPEB-UNESP). Realiza pesquisas em Ensino de Ciências, com foco no Ensino de Biologia, Epistemologia da Biologia e História da Ecologia.

\section{FERNANDO HITOMI MATSUBARA}

Graduação em Ciências Biológicas pela Universidade Estadual do Paraná (UEL/2004-2008); Mestrado em Biologia Celular e Molecular pela Universidade Federal do Paraná (UFPR/20092011); Doutorado em Biologia Celular e Molecular pela Universidade Federal do Paraná (UFPR/2011-2015); Professor do Departamento de Patológica Básica da Universidade Federal do Paraná (UFPR/2017), atuando nos cursos de Medicina, Farmácia, Biomedicina e Fisioterapia; Professor na Universidade Positivo (UP/2017-atual), atuando nos cursos presenciais de Biomedicina, Nutrição e Engenharia de Bioprocessos, e no curso semipresencial de Biomedicina.

\section{GABRIEL DOS SANTOS PAULON}

Mestrando pelo Programa de Pós-graduação em Rede Nacional para o Ensino de Ciências Ambientais. Possui graduação em Ciências Biológicas pela Faculdade de Filosofia, Ciências e Letras de Ribeirão Preto, Universidade de São Paulo (2017). Tem experiência na área de Recursos Florestais e Engenharia Florestal, com ênfase em Conservação de Bacias Hidrográficas. Atualmente desenvolve pesquisas no Laboratório de Epistemologia e Didática da Biologia (LEDiB), nas áreas de Ensino de Ciências, Formação de professores e Interdisciplinaridade.

\section{GISELLE ALVES MARTINS}

Doutoranda e Mestra em Ciências pelo Programa de Pós-graduação em Biologia Comparada (Linha de pesquisa: História, Filosofia e Ensino de Evolução e Ecologia) pela Faculdade de Filosofia, Ciências e Letras de Ribeirão Preto - Universidade de São Paulo (FFCLRP-USP). Atualmente desenvolve atividades de ensino, pesquisa e extensão no Laboratório de Epistemologia e Didática da Biologia (LEDiB: www.ledibusp.com.br) com temas relacionados ao Ensino de Ciências, Formação de Educadores Ambientais, Interdisciplinaridade e Filosofia da

Ciência.

Licenciada e Bacharel em Ciências Biológicas pela Universidade Federal de Uberlândia, onde atuou como bolsista de iniciação científica pelo Laboratório de Ecologia e Comportamento de Abelhas (LECA), como monitora em Espaços não-formais de ensino (Museu Dica e Museu de Biodiversidade do Cerrado) e como estagiária responsável pela construção de recursos didáticos no Laboratório de Ensino (LEN). 
Mestre em Educação pelo Programa de Pós-graduação em Educação em Ciências e Matemática no Instituto Federal do Espírito Santo - Campus Vitória (ES). Graduado em Licenciatura Plena em Ciências Biológicas pelo Centro Universitário São Camilo - Campus Espírito Santo. Especialização Lato Sensu em Docência do Ensino Superior pela Faculdade de Educação da Serra. Especialista em Gestão da Educação, com habilitação em Administração, Supervisão, Inspeção, Coordenação e Orientação Educacional pela Faculdade de Nanuque (MG). Especialização em Educação e Gestão Ambiental pela Faculdade de Tecnologia de Cachoeiro de Itapemirim (ES).Professor Estatutário de Ciências na Educação Básica pela Prefeitura Municipal de Marataízes. Possui experiência na docência de Ciências Naturais e Biologia na Educação Básica e no Nível Superior, além de atuar em Programas Municipais de Formação Continuada para professores da Educação Básica. Desenvolve pesquisas voltadas para Estratégias Metodológicas para o ensino de Ciências Naturais e Biologia em ambientes formais e não formais, além de promover investigações acadêmicas sobre Gênero e Sexualidade na Educação.

\section{ISADORA JORGE VELLOSO}

Graduação em andamento em Química na Universidade do Estado de Santa Catarina, UDESC, Brasil

\section{JAKELINE AMPARO VILLOTA ENRÍQUEZ}

Est. Phd. In Education. Mestra em Ensino, Filosofia e História das Ciências. Licenciada em Matemáticas. Professora adscrita à Facultade de Educação da Universidad Santiago de Cali, Colombia. Lider del grupo de pesquisa CIEDUS adscrito a COLCIENCIAS.

\section{JORGE RAIMUNDO DA TRINDADE SOUZA}

Graduação em Química Industrial pela Universidade Federal do Pará (1985), Mestrado em Geologia e Geoquímica pela Universidade Federal do Pará (1995) e doutorado em educação em Ciências no Programa de Pós-graduação em Educação em Ciências e Matemáticas (IEMCI / UFPA) (2016). Atualmente é professor Associado I da Universidade Federal do Pará. Tem experiência na área de Educação, com ênfase em Métodos e Técnicas de Ensino, atuando principalmente nos seguintes temas: CTS, Ensino e aprendizagem em Química e Ciências Naturais e Prática Pedagógica em Química e Ciências Naturais.

\section{JOSÉ ALEXANDRE DA SILVA VALENTE}

Graduação em Física Licenciatura e Engenharia Mecânica pela Universidade Federal do Pará (UFPA), Especialização em Física Moderna e Contemporânea pela UFPA, Mestrado e Doutorado em Educação em Ciências pelo programa de Pós-graduação em Educação em Ciências e Matemática (IEMCI/UFPA). Professor da UFPA atuando na Escola de Aplicação e na Faculdade de Ciências Naturais. Tem experiência na área de Educação com ênfase na Educação em Ciências, no Ensino de Física e na Neuroeducação, atuando principalmente nas seguintes temáticas: Enfoque CTS (Ciência, Tecnologia e Sociedade), Educação para Sustentabilidade, Formação de Professores, Ensino e Aprendizagem de Ciências, Prática Pedagógica em Ciências Naturais, Experimentação, Formação de Conceito e Teoria da Carga Cognitiva

\section{JOSÉ CLÁUDIO DEL PINO}

Licenciado em Química - PUC-RS, graduado em Química Indústrial - PUC-RS, mestrado em Ciências Biológicas-Bioquímica - UFRGS, doutorado em Engenharia de Biomassa - UFRGS e pós-doutorado pela Universidade de Aveiro-Portugal (2004). Atualmente é professor associado da UFRGS. Professor-Orientador do PPG Educação em Ciência Química da Vida e Saúde e do PPG Química - UFRGS. Bolsa de Produtividade em Pesquisa do Conselho 
Nacional de Desenvolvimento Científico e Tecnológico. Tem experiência acadêmica na área de Educação, com ênfase em Educação Química, atuando principalmente nos seguintes temas: formação de professores, ensino de química, material didático, currículo de química e informática educativa.

\section{JOSÉ DANIEL SOLER GARVES}

Graduado em Ciências Biológicas (Licenciatura) e graduando em Ciências Biológicas (Bacharelado) na Universidade Estadual Paulista - Faculdade de Engenharia de Ilha Solteira (UNESP - FEIS), no qual desenvolveu projetos de elaboração de materiais didáticos de ciências naturais para utilização em aulas práticas no Ensino Fundamental. Foi bolsista PIBID (Programa Institucional de Bolsa de Iniciação à Docência) e bolsista do Programa Núcleo de Ensino - PROGRAD - UNESP, onde realizou projetos com fins didáticos visando sua formação docente e atividades relacionando conceitos ambientais com enfoque ao meio ambiente urbano. Atualmente, é bolsista do Programa Institucional de Bolsas de Iniciação Científica (PIBIC), pesquisando Ecologia de Peixes.

\section{JUÇARA PEREIRA BARBOSA}

Graduada em Pedagogia pela Faculdades São José, pós graduada latu senso especialização em Docência do Ensino Superior pela Universidade Estácio de Sá, pós graduanda especialização em Psico pedagogia Clínica e Institucional pela Faculdades São José.

\section{LICURGO PEIXOTO DE BRITO}

É licenciado em Ciências Naturais (1979), em Física (1984) e doutor em Geofísica (1994) títulos obtidos junto a Universidade Federal do Pará - UFPA. Atualmente é professor Associado IV da UFPA, lotado no Instituto de Ciências Exatas e Naturais e no Instituto de Educação Matemática e Científica, atuando na graduação e na pós-graduação. Coordena o Polo Acadêmico UFPA-REAMEC para formação de doutores em Educação em Ciências e Matemática na Amazônia Legal brasileira. Possui experiência em Gestão Acadêmica tanto na UFPA quanto na SEDUC/PA. Participou de comissões junto ao MEC, INEP e CAPES. Atualmente dedica-se à pesquisa em Ensino de Ciências com enfoque CTS, atuando principalmente em Ensino de Física Através de Temas, com ênfase em temas regionais da Amazônia.

\section{LUANA BEATRIZ XAVIER NUNES}

Possui licenciatura e bacharelado em Ciências Biológicas pela Universidade Presbiteriana Mackenzie (2016) , atualmente é mestranda no Programa Interunidades em Ensino de Ciências na Universidade de São Paulo com a linha de pesquisa de História, Filosofia e Cultura no Ensino de Ciências. É professora titular na rede municipal de ensino em São Paulo, com experiência o Ensino Fundamental e Médio.

\section{MAGDA MEDHAT PECHLIYE}

Possui graduação em Ciências Biológicas pela Universidade de São Paulo (1989), especialização na área de Educação mestrado e doutorado em Educação pela Universidade de São Paulo (2002 e 2010 respectivamente). Já trabalhou em diversas instituições de ensino tanto particular como da rede municipal. Tem experiência de 29 anos no magistério. Entre 2003 e 2009 foi professora de ciências e projetos no ensino fundamental do Colégio Oswald de Andrade, instituição para qual prestou assessoria. Atualmente é professora, tempo integral, 
da Universidade Presbiteriana Mackenzie (UPM) em várias disciplinas relacionadas à formação de professores. Nos anos de 2015 e 2016 foi membro do CEPE (Conselho de Ensino Pesquisa e Extensão) da UPM. Faz parte do NDE (Núcleo Docente Estruturante) do curso de Ciências Biológicas. É responsável pelos trabalhos de conclusão de curso da licenciatura do curso de ciências biológicas, orienta trabalhos de conclusão de curso e participa de bancas que avaliam esse tipo de trabalho. Coordena o programa PIBID no subprojeto de Biologia. Têm publicações em diversos periódicos. Sua linha de pesquisa é a de formação de professores e no ensino de Ciências e Biologia. Atualmente é líder de pesquisa de um grupo que trabalha com as ideais de Humberto Maturana e suas implicações para o ensino de Ciências e Biologia.

\section{MANUELLA VILLAR AMADO}

Coordenadora da Especialização em Educação e Divulgação em Ciências (EDIV) e Coordenadora Adjunta da Especialização em Ensino Interdisciplinar em Saúde e Meio Ambiente na Educação Básica - Ifes- Campus Vila Velha. Atua como professora e orientadora do mestrado profissional do Programa de Pós-graduação em Educação em Ciências e Matemática (EDUCIMAT) e do Programa de Pós-graduação em Química em Rede ( ProfQUI). Atua como pesquisadora na área de Ensino de Ciências realizando pesquisas em Educação Científica e em Espaços de Educação Não Formal. Graduada em Ciências Biológicas pela Universidade Federal do Espírito Santo (2002), Mestre em Ciências Biológicas pela Universidade Federal do Espírito Santo (2004), Doutora em Biotecnologia pela Universidade Federal do Amazonas (2008) e Pós-doutora na área de Divulgação e Ensino das Ciências pela Faculdade de Ciências da Universidade do Porto- Portugal (2014). Tem experiência nas áreas de Biologia Animal, Ecologia, Genética da Conservação, Biologia Molecular, Biotecnologia, Ensino de Ciências, Alfabetização Científica, Espaços Educativos Não Formais, Educação para uma Cultura Sustentável.

\section{MARCELA ARANTES RIBEIRO}

Mestre em Geografia pela Universidade Federal de Rondônia. Especialista em Arte, Educação e Saúde, e, especialista em Educação Especial e Inclusiva, ambas pela Universidade Cândido Mendes. Bacharel e Licenciada em História pela Universidade Federal de Rondônia. Área de conhecimento Educação.

\section{MARIA ELISE SONNENHOHL}

Possui graduação em Tecnologia em Aquicultura pela Universidade Federal do Paraná(2013) e ensino-medio-segundo-graupela SENAI - Departamento Regional de Santa Catarina(2007). Atualmente é da Universidade do Estado de Santa Catarina.

\section{MARIBEL DEICY VILLOTA ENRÍQUEZ}

Mestra em Ciência, Tecnologia e Sociedade. Antropóloga. Universidade Federal de São Carlos

\section{MICHELLE CÂMARA PIZZATO}

Possui graduação em Química Licenciatura pela Universidade Federal do Rio Grande do Sul (1998), mestrado em Ensino de Ciências (Modalidade Química) pela Universidade de São Paulo (2002) e doutorado em Ensino de Ciências pela Universidad de Burgos (2010). Atualmente é professora do Instituto Federal de Educação, Ciência e Tecnologia do Rio 
Grande do Sul, Campus Porto Alegre. Tem experiência na área de Educação em Ciências, com ênfase em Didática e Epistemologia das Ciências, atuando principalmente nos seguintes temas: formação de professores, ideias dos alunos, ensino de química, história e filosofia das ciências e concepções e práticas docentes.

\section{NACYRA YIBURI FERNANDES DE LUCENA}

Graduada em Pedagogia Simonsen RJ e em Ciências Biológicas FTESM RJ Pós graduada latu sensu especialização em Biologia Geral UCMG MG, em Orientação Educacional SML RJ ,em Tecnologia Educacional FSJT RJ , em Ensino de Ciências UERJ RJ, em Informatica Aplicada a Educação UCP RJ, em Educação a distância SENAC RJ, em Psicopedagogia UCDM SP e em Educação especial Inclusiva AVM SP. Pós Graduada stictu sensu mestrado em Educação UCP RJ

\section{PATRÍCIA REGINA CARVALHO OTTZ}

Mestre em Educação em Ciências e Matemática pelo Instituto Federal do Espírito Santo - IFES, atuando principalmente na pesquisa dos seguintes temas: ensino de Ciências da Natureza, alfabetização científica e aprendizagem baseada na resolução de problemas. Especialista em Metodologia de Ensino de Ciências e Biologia pelo PREPES - PUC/MG. Possui graduação em Biologia pela Faculdade de Filosofia, Ciências e Letras de Carangola (MG). Atualmente é professora de Ciências da rede municipal de Aracruz (ES).

\section{PAULA DE OLIVEIRA SOUZA}

Graduanda do curso de Ciências Biológicas na Faculdade de Filosofia, Ciências e Letras de Ribeirão Preto da Universidade de São Paulo. Atualmente faz Iniciação Científica no Laboratório de Epistemologia e Didática da Biologia (LEDiB) pesquisando sobre a Interdisciplinaridade na formação inicial de professores de ciências.

\section{PAULA MOIANA DA COSTA}

Graduação em Biomedicina pela Universidade Federal de Goiás (1999); Mestrado em Biologia pela Universidade Federal de Goiás (2003); Doutorado em Genética pela Universidade Federal do Paraná (2011); atuou como professora na área de Genética, Biologia Celular e Metodologia Cientifica e Filosofia da Ciência; coordenou e implantou cursos de Biomedicina presencial e semipresencial; realiza treinamento de professores para o uso de metodologias ativas e inovação acadêmica; fundadora do Instituto Soren.

\section{REJANE ARAÚJO DA SILVA}

Graduada em Pedagogia e Pós-graduanda em Psicopedagogia.

\section{RITA DE CÁSSIA BORGES DE MAGALHÃES AMARAL}

Possui graduação em Pedagogia pela UFRJ, Habilitações em Supervisão Escolar e Magistério das Disciplinas Pedagógicas, e FEFIS - Habilitação em Administração Escolar; Especialização em Planejamento Educacional- FEFIS; Especialização em Gestão da Educação a DistânciaUFJF; Especialização em Planejamento, Implementação e Gestão da Educação a Distância UFF; Mestrado em Sociologia pela UFRJ, Doutorado em Engenharia de Produção pela UFRJ e Pós-Doutorado (em curso) pela PUC-SP. Tem experiência nas áreas de Assessoria de 
Projetos Educacionais, Gestão da Educação Básica e Superior nas modalidades presencial e a distância, Coordenação Pedagógica.

\section{ROBERTO BARBOSA DE CASTILHO}

Professor Associado - Instituto de Química - UFRRJ: 2017- Professor Adjunto - Departamento de Química - ICE - UFAM - 2009-2016 Analista de Produção - BioManguinhos - FioCruz-RJ 2007-2009. Doutor em Físico-Química - UFRJ - 2006. Graduado em Farmácia - UFRJ - 2001

\section{ROSANA CHERMONT MESQUITA}

Mestranda na Universidade Federal do Pará (UFPA)/ Instituto de Educação Matemática e Científica (IEMC). Especialista em Educação Fundamental pela Universidade da Amazônia (1996).Possui graduação em Pedagogia pela Universidade Federal do Pará, com habilitação em Magistério, Supervisão Escolar, Administração Escolar e Orientação Educacional(1992). Atualmente é membro da Equipe de Pesquisa do Núcleo de Planejamento da Secretaria Municipal de Educação de Belém do Pará, desenvolvendo processo de Formação Continuada para Conselheiros Escolares (Professores, Pais, Alunos) e Equipe Diretiva das Escolas da Rede Municipal de Ensino. Tem experiência na área de Educação, com ênfase em Planejamento e Avaliação Educacional, Formação de Professores e Legislação Educacional.

\section{SAMIA MOREIRA AKEL}

Bacharel em Fisioterapia - UTP; Mestra em Fisiologia Humana - UFPR; Doutoranda em Ciências da Saúde - PUCPR; Atua como professora nos cursos presenciais e semipresenciais de Biomedicina e no curso presencial de Nutrição - Universidade Positivo.

\section{SANDRA APARECIDA DOS SANTOS}

Licenciada em Biologia/UNIVALI-SC, Mestre em Educação em Ciências Química da Vida e Saúde /UFRGS- RS e doutoranda em Educação em Ciências Química da Vida e Saúde/UFRGS. Atualmente é professora no Centro Universitário UNIDAVI - SC, atua na Educação Básica e Licenciatura em Biologia, sendo que a área de pesquisa concentra-se na experimentação no ensino, uso de livros de divulgação científica no Ensino de Ciências, Iniciação Científica e História da Ciência. Ministra as disciplinas de Ciências, Biologia e Metodologia do Ensino de Biologia.

\section{TAITIÂNY KÁRITA BONZANINI}

Graduada em Ciências Biológicas pela Universidade Estadual Paulista Júlio de Mesquita Filho (UNESP/Bauru) (2002), possui Licenciatura Plena em Pedagogia, especialização pelo Programa de Formação a Distância em Mídias Integradas na Educação da USP (2009), mestrado (2005) e doutorado (2011) em Educação para a Ciência pela UNESP campus Bauru. Atualmente professora doutora da Escola Superior de Agricultura Luiz de Queiroz (ESALQ/ USP). Professora nos Programas de Pós-graduação: Ecologia Aplicada Interunidades PPGI/ESALQ/CENA e no PROFCIAMB - Programa de Pós-graduação em Rede Nacional para o Ensino de Ciências Ambientais. Atua nas áreas: Ensino de Ciências e Biologia, Formação de Professores e Instrumentação para o Ensino e Educação a Distância. 


\section{TATIANA COMIOTTO}

Graduação em Psicologia pela Associação Catarinense de Ensino (2014), graduação em Pedagogia pela Universidade de Caxias do Sul (1986), mestrado em Educação pela Pontifícia Universidade Católica do Rio Grande do Sul (1991) e doutorado em Educação Cientifica e Tecnológica pela Universidade Federal de Santa Catarina (2008). Atualmente é professora associada da Universidade do Estado de Santa Catarina. Tem experiência na área de Educação, com ênfase em Psicologia da Educação, atuando principalmente nos seguintes temas: CTS - Ciência, Tecnologia e Sociedade, Ensino de Química, Representações Sociais, Educação e Materiais didático-pedagógicos.

\section{VERONICA RIBEIRO DA SILVA CORDOVIL}

Mestre em Geografia pela Universidade Federal de Rondônia. Bacharel em Direito pela Faculdade de Ciências Humanas, Exatas e Letras de Rondônia. Doutorando em Ciência da Informação pela Universidade de São Paulo. 
Agência Brasileira do ISBN ISBN 978-85-93729-74-4

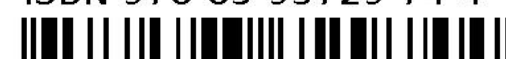

. 